Department of Landscape, Spatial and Infrastructure Sciences

Institute of Landscape Architecture (ILA)

Head of Institute: Univ. Prof. Dipl.-Ing. Lilli Licka

\title{
Sustainable Technology
}

Studies on User Innovation, Social Learning and Innovation Networks

Habilitation Thesis

University of Natural Resources and Applied Life Sciences Vienna

Submitted by

\section{Michael Ornetzeder}

Vienna, April 2010 


\section{Sustainable Technology}

Studies on User Innovation, Social Learning and Innovation Networks

Michael Ornetzeder 


\section{Acknowledgements}

The process of reframing and putting together these papers has given me reason to look back with gratitude. Many people both inside and outside the scientific community have been an integral part of this work as co-authors, tutors, colleagues, friends and encouraging clients. I am grateful to all of them.

Over the last ten years, I have had the opportunity to do research with colleagues from a variety of disciplines in quite a large number of projects. A great deal of these efforts resulted in joint publications, and some of them eventually found their way into this collection. I very much enjoyed working on each of these papers and I am very thankful to all of my co-authors: Ulrike Bechtold, Willi Haas, Edgar Hertwich, Klaus Hubacek, Katarina Korytarova, Michael Nentwich, Harald Rohracher, Anna Schreuer, Markus Starkl and Jürgen Suschek-Berger.

I also would like to thank Josef Hochgerner, who first drew my attention to the field of the sociology of technology. Jo also introduced me to the people from the Appropriate Technology Group at the University of Technology in Vienna, who had a deep and enduring effect on my thinking about technology. Later he became an inspiring tutor and supervisor and supported my research activities for many years at the Centre for Social Innovation.

I am grateful to all of my colleagues at the Institute of Technology Assessment for inspiring discussions on the various aspects of TA (and beyond) and for actively providing an excellent working atmosphere. I benefited a lot from being part of the ITA team, and my understanding of TA has been particularly broadened during the years I have worked with them. I also benefited from passionate discussions on sustainable development with Ulrike and Mahshid.

A special thanks goes to my colleagues Georg Aichholzer, Ulrich Fiedeler, Michael Nentwich, and Harald Rohracher, all of whom gave me crucial advice on earlier drafts of this outline paper. Although I did not succeed in following all of the ideas for improvements that were offered, I hope that I will be able to incorporate them into my future research. I also would like to thank Casey Butterfield for her excellent proofreading of my manuscript. I was happy to accept nearly all suggestions for improvement.

I also have to mention Lilli Licka, who did a wonderful job as my mentor for my habilitation project at the University of Natural Resources and Applied Life Sciences.

This research of course would not have been possible without important institutional and financial support. The Austrian Academy of Sciences provided excellent conditions for doing academic work. In addition, I have had the good fortune to enjoy financial contributions to my research from three Federal Ministries (Transport, Innovation and Technology; Agriculture, Forestry, Environment and Water Management; Economics and Labour), from the Austrian Council for Research and Technology Development, the Austrian Climate and Energy Funds, and the Jubiläumsfonds der Österreichischen Nationalbank. Michael Paula from the Ministry for Transport, Innovation and Technology deserves particular appreciation for spearheading sustainability research in Austria. A great 
deal of this research would not have been possible without his visionary thinking and steady commitment to the idea of sustainability.

Finally, I also want to thank my mother, Annelie Ornetzeder, and my parents-in-law, Martha and Isfried Mayrhofer, for their general support and especially for the babysitting during those many times when the workload was too much or there were tempting conferences abroad in the offing. Most especially I want to thank my wife, Rita, for her continuing support and encouragement, and for never talking about deadlines.

Vienna, April 2010

Michael Ornetzeder 


\section{Contents}

\section{Part A: Outline Paper}

\section{Acknowledgements}

1 Introduction 1

2 User innovation, social learning and innovation networks 5

3 Experiences with and reflections on TA exercises 24

4 Research Strategies and Methods 36

5 Conclusion and Outlook 43

Annotated list of articles $\quad 47$

$\begin{array}{ll}\text { References } & 49\end{array}$

\section{Part B: Selected Articles}

Article I Ornetzeder, M., 2001, Old Technology and Social Innovations. Inside the Austrian Success-Story on Solar Water Heaters, in: Technology Analysis \& Strategic Management, Volume 13, Number 1, March, pp. 269-278

Article II Rohracher, H., Ornetzeder, M., 2002, Contextualising Green Buildings: Improving Social Learning Processes between Users and Producers, in: Built Environment, Volume 28, Number 1, pp. 73-84

Article III Ornetzeder, M., 2003, Sustainable Technology and User Participation. Assessing Ecological Housing Concepts by Focus Group Discussions, in: Mira, Ricardo Garcia/Jose Manuel Sabucedo Cameselle/Jose Romay Martinez (eds.): Gulture, Environmental Action and Sustainability, pp. 145-160

Article IV Ornetzeder, M., Rohracher, H., 2006, User-led Innovations and Participation Processes: Lessons from Sustainable Energy Technologies, in: Energy Policy, Volume 34, Issue 2, January, pp. 138-150

Article V Ornetzeder, M., Hertwich, E., Hubacek, K., Korytarova, K., Haas, W., 2007, The Environmental Effect of Car-free Housing: A Case in Vienna, in: Ecological Economics 65, pp. 516-530

Article VI $\quad$ Starkl, M., Ornetzeder, M., Binner, E., Holubar, P., Pollak, M., Dorninger, M., Mascher, F., Fuerhacker, M., Haberl, R., 2007, An Integrated Assessment of Options for Rural Wastewater Management in Austria, in: Water Science \& Technology, Vol 56 No 5 pp. 105-113

Article VII Ornetzeder, M., Suschek-Berger, J., 2008, Innovation Networks in the Refurbishment Sector of Austria: Promising Approaches Waiting for Market Success, in: International Fournal of Innovation and Sustainable Development, Vol. 3, Nos. ${ }^{3 / 4}$, pp. 285-300

Article VIII Ornetzeder, M., Rohracher, H., 2009, Passive Houses in Austria: The Role of Intermediary Organisations for the Successful Transformation of a Socio-technical System, in: Broussous, C., Jover, C., (eds.), Act! Innovate! Deliver! Reducing energy demand sustainably, Conference proceedings, eceee 2009 Summer Study, Stockholm, pp. 1531-1541

Article IX Ornetzeder, M., Bechtold, U., Nentwich, M., 2009, Participatory Assessment of Sustainable End-user Technology in Austria, in: Brebbia, C.A. and Mammoli, A.A., (eds.), Energy and Sustainability II, WIT press, Southampton and Boston, pp. 269-278

Article X Schreuer, A., Ornetzeder, M., Rohracher, H., 2010, Participatory Technology Development and Assessment: In Search of a Sustainable Use of Fuel Cell Technology at the Municipal Level, in: Technology Analysis \& Strategic Management, forthcoming 


\title{
Outline Paper
}

\author{
Part A
}




\section{Sustainable Technology: Studies on User Innovation, Social Learning and Innovation Networks}

\section{Introduction}

The body of work presented in this collection investigates sustainable technological innovation from a science and technology studies (STS) point of view. Helga Nowotny (2009) recently argued that the 'green technologies' currently underway are one of the main challenges to STS research. 'It would be interesting,' Nowotny says, 'to follow the various trajectories, actors and their arenas, comparing the scientific-technological problem-spaces green technologies inhabit and the spatial and temporal scales on which they will materialise, shaping and being re-shaped by society' (ibid. 4). In my studies, I have focused on novel and promising sustainable technologies at early stages of development. With such a focus we can gain valuable insights into the dynamics of technological innovation, as well as discuss its early impacts on society and perhaps find ways to minimise its negative and maximise its positive effects.

The articles presented in this overview not only cover theoretically framed empirical studies, but also report on experiences with and results of advisory projects in technology assessment (TA). My work in this context can be seen as an attempt to contribute to what Sismondo (2008b, p. 21) calls an 'engaged programme' of science and technology studies: research that addresses 'topics of clear political importance' and tries to place 'relations among science, technology, and public interest at the centre of the research programme'. Even if my examples only meet the requirements for an 'engaged programme' in a rudimentary and provisional form, the basic idea - that research is done with a sense of mission, and that findings are closely coupled with and used in professional service projects - should already be visible.

The mission I refer to here is that of sustainable development; the discourse on this subject has influenced my research in both normative and methodological terms. Unlike the classical environmental protection concepts of the 1970s and 1980s, sustainable development has been framed as a strategy for active modernisation and structural change. The widely accepted vision of sustainable development, as formulated in one of the key documents, the Agenda 21 (United Nations 1993), aims to combine environmental protection goals with stable economic conditions based on principles of social justice. The Agenda 21 programme established normative goals (objectives) as well as the procedural instructions to achieve these goals (activities, means of implementation), and this dualism has become a characteristic feature of most of the sustainability programmes and concepts developed since then. We can find this dualism in political programmes (e.g. EnqueteKommission 1998; United Nations 1993; BMLFUW 2002) and in scientific sustainability concepts (e.g. BUND/Misereor 1996; Kopfmüller et al. 2001; Renn et al. 2007) as well. 
Both the objectives and the methods to approach the objectives, however, cannot be fixed once and for all. They display a dynamic dependence, mutually open to new ideas, strategies and options. Or as Kasemir et al. (2003, p. xxiii) put it:

Sustainability cannot be approached by a grand master plan with a precise mapping of the end point and the trajectory to get there. Rather, it is 'our common journey' as humankind; it consists of one tentative step after the other, with the need for continuous feedback whether we are going roughly in the right direction or not (National Research Council 1999).

My own work reflects this interplay of normative orientation and methodological effort. The selection of research topics is clearly driven by the idea that sustainability can be promoted by novel technology that is somehow different, and so in the last ten years I have focused on technologies with a high potential for sustainability, e.g. solar water heaters, biomass systems, photovoltaics, fuel cells, passive houses, sustainable refurbishments, smart home technology and ecological sanitation. These technologies often had to compete with already well-established technical solutions, and my research therefore addresses issues that both reflect ongoing innovation processes and may also help to improve them.

In recent years, the issue of climate change has become a central subject of sustainability. There is a broad consensus in academia that mitigating climate change requires a radical transformation of the existing energy system (Metz/Intergovernmental Panel on Climate Change. Working Group III. 2007). A shift from fossil fuels to renewables is needed, as are higher levels of efficiency, and technologies such as fuel cells and ultra-low-energy buildings are important elements in this transformation process. Reflecting on these technologies, still in their early stages of development and dissemination, could help to improve our understanding of sustainable innovation, and it could help us to find and forge pathways to a low-carbon society.

Technology assessment (TA), my second field of activity, is also challenged by the idea of sustainability. Sustainability changes the conditions for the development of technology. Grunwald (2002b) argues that technological innovation must be conceptualised as a process of open learning, stimulating discussions on societal aims and technological options using scientific knowledge and cultural values. In such a process, sustainable technology may emerge gradually as the result of recursive loops of learning. With sustainability as a guiding vision, however, technological innovation has now definitely become much more difficult and complex.

According to Fleischer and Grunwald (2002), TA with a special focus on sustainability has to identify and announce a set of criteria that enable the technology to shift towards more sustainability; the assessment must analyse the direct and indirect effects of a given technology, regarding ecological, social and economic dimensions, and support not only technology policy, but also technology-relevant decisions in research institutes and industry. TA that uses sustainability as a reference point is forced to apply a long-term perspective and to take an integrative assessment approach, which means that a broad range of criteria has to be considered. Moreover, participation of relevant stakeholders, or even lay citizens, must be taken into account. The increased emphasis on discursive assessment approaches reflects these novel requirements. 
Table 1 Overview of the selected articles in chronological order

\begin{tabular}{|c|c|c|c|c|c|}
\hline Article & Topic & Research focus & TA focus & Approach & Methodology \\
\hline I & $\begin{array}{l}\text { Renewable energy } \\
\text { technology (thermal } \\
\text { solar) }\end{array}$ & $\begin{array}{l}\text { Diffusion of } \\
\text { innovation } \\
\text { User innovation }\end{array}$ & none & Discipline-based & $\begin{array}{l}\text { Qualitative and } \\
\text { quantitative }\end{array}$ \\
\hline II & $\begin{array}{l}\text { Low-energy } \\
\text { buildings } \\
\text { Ventilation systems }\end{array}$ & $\begin{array}{l}\text { User behaviour } \\
\text { Embedding } \\
\text { Social learning }\end{array}$ & none & Discipline-based & $\begin{array}{l}\text { Qualitative and } \\
\text { quantitative }\end{array}$ \\
\hline III & $\begin{array}{l}\text { Low-energy } \\
\text { buildings } \\
\text { Green architecture }\end{array}$ & $\begin{array}{l}\text { User participation } \\
\text { in innovation } \\
\text { processes }\end{array}$ & $\begin{array}{l}\text { Assessment of } \\
\text { ecological housing } \\
\text { concepts }\end{array}$ & Discipline-based & Qualitative \\
\hline IV & $\begin{array}{l}\text { Renewable energy } \\
\text { technology } \\
\text { Energy efficiency }\end{array}$ & $\begin{array}{l}\text { User innovation } \\
\text { Social learning } \\
\text { Communities of } \\
\text { practice }\end{array}$ & $\begin{array}{l}\text { User participation } \\
\text { Constructive TA }\end{array}$ & Discipline-based & Qualitative \\
\hline $\mathrm{V}$ & $\begin{array}{l}\text { Climate change } \\
\text { Car-free housing }\end{array}$ & $\begin{array}{l}\text { User behaviour } \\
\text { Sustainable } \\
\text { consumption } \\
\text { Household } \\
\text { environmental } \\
\text { impact (HEI) }\end{array}$ & none & Interdisciplinary & $\begin{array}{l}\text { (mainly) } \\
\text { Quantitative }\end{array}$ \\
\hline VI & $\begin{array}{l}\text { Rural wastewater } \\
\text { management }\end{array}$ & $\begin{array}{l}\text { Social acceptance } \\
\text { Embedding }\end{array}$ & $\begin{array}{l}\text { Integrated } \\
\text { assessment } \\
\text { User participation }\end{array}$ & Multidisciplinary & $\begin{array}{l}\text { Qualitative and } \\
\text { quantitative } \\
\text { Focus groups }\end{array}$ \\
\hline VII & $\begin{array}{l}\text { Sustainable } \\
\text { refurbishment of } \\
\text { single-family houses }\end{array}$ & $\begin{array}{l}\text { Innovation } \\
\text { networks } \\
\text { Diffusion of } \\
\text { innovation }\end{array}$ & none & Discipline-based & $\begin{array}{l}\text { Qualitative and } \\
\text { quantitative }\end{array}$ \\
\hline VIII & $\begin{array}{l}\text { Ultra-low-energy } \\
\text { buildings }\end{array}$ & $\begin{array}{l}\text { Socio-technical } \\
\text { systems } \\
\text { Intermediation } \\
\text { Strategic niche } \\
\text { management }\end{array}$ & none & Discipline-based & Qualitative \\
\hline IX & $\begin{array}{l}\text { Sustainable energy } \\
\text { research } \\
\text { End-user } \\
\text { technology }\end{array}$ & $\begin{array}{l}\text { Impact of } \\
\text { participation }\end{array}$ & $\begin{array}{l}\text { Vision Assessment } \\
\text { Innovation- } \\
\text { oriented TA }\end{array}$ & Interdisciplinary & $\begin{array}{l}\text { Qualitative and } \\
\text { quantitative }\end{array}$ \\
\hline $\mathrm{X}$ & Fuel cell technology & $\begin{array}{l}\text { Socio-technical } \\
\text { mapping }\end{array}$ & $\begin{array}{l}\text { Constructive TA } \\
\text { Demand } \\
\text { articulation }\end{array}$ & Discipline-based & Qualitative \\
\hline
\end{tabular}

Research in the field of sustainability alters methodological assumptions too. Voss and Kemp (2006) propose to draw on sustainability in the first instance 'as a specific kind of problem framing that emphasises the interconnectedness of different problems and scales, as well as the long-term and indirect effects of actions that result from it' (ibid: 4). Sustainability research tends to be cross- or transdisciplinary, since it privileges socially robust explanations and tries to capture the whole picture rather than every detail (e.g. Nowotny et al. 2001; Loibl 2006; Pohl et al. 2010). Projects that focus on sustainability are defined by societal problems rather than by the internal logic of science. Therefore, 
sustainability research 'serves the quest for advancing both useful knowledge and informed action by creating a dynamic bridge between the two' (Clark 2007, p. 1737). For this reason, sustainability research shares quite a lot with science and technology studies. STS revolves around the question of how social, political, and cultural conditions affect scientific research and technological innovation (and how these in turn affect society) and draws on a variety of disciplines, including anthropology, history, political science, and sociology.

I have two main goals with this introductory paper: First, I present each of the ten selected papers in brief, and second, I discuss important findings within broader theoretical and methodological contexts.

The selection of papers gives an adequate overview on my research activities of the last ten years. As we can see in Table 1, this work has been characterised by a strong focus on sustainable technology used either in or in connection with residential buildings. Such technology includes single devices (e.g. solar heaters, ventilation systems), as well as larger technological systems (e.g. wastewater management infrastructure) and sustainable concepts (e.g. green architecture, ultra-low energy buildings). We can also see that articles with a clear research focus alternate with articles that try to combine research with discursive forms of technology assessment. Most articles describe discipline-based social research projects, but there are some distinctive examples that use cross-disciplinary approaches as well. From a methodological point of view, mixed-method designs clearly dominate the picture.

This outline paper presents three main aspects of my research activities: In Chapter 2 a brief overview on STS concepts is given, in particular my own contributions to user innovation, social learning, and sustainable innovation networks. Chapter 3 provides an introduction to constructive technology assessment (CTA) and reports on experiences and outcomes for a number of discourse-oriented TA projects. In Chapter 4 I briefly respond to the empirical basis of the articles and discuss three specific methodological aspects of my work. In the concluding chapter of this overview, I provide a short outlook on important aspects of future research in the field of sustainable technology. 


\section{User innovation, social learning and innovation networks}

The articles presented in this chapter could best be described as a contribution to science and technology studies (STS) from a sociology of technology perspective. STS emerged as a new cross-disciplinary field in the 1970s (Spiegel-Rösing/de Solla Price 1977), bringing together the work of sociologists, historians, philosophers, and anthropologists to focus on the processes and outcomes of science and technology. Since then, STS research has brought fundamental changes to our understanding of the origins, dynamics and consequences of science and technology.

The most powerful assumption made in STS research was to address science and technology as thoroughly social activities. Sismondo (2008a) summarises the main implications of that assumption as follows:

[Science and technology] are social in that scientists and engineers are always members of communities, trained into those communities and necessarily working within them. Communities, among other things, set standards for inquiry and evaluate knowledge claims; there is no abstract and logical scientific method apart from the actions of scientists and engineers. [...] The actors in science and technology are also not mere logical operators, but instead have investments in skills, prestige, knowledge, and specific theories and practices.

[...] Neither science nor technology is a natural kind, having simple properties that defines [sic] it once and for all. The sources of knowledge and artefacts are complex and various: there is no scientific method to translate nature into knowledge, and no technological method to translate knowledge into artefacts. In addition, the interpretations of knowledge and artefacts are complex and various: claims, theories, facts, and objects may have very different meanings to different audiences. (Sismondo 2008a, p. 10)

By making this assumption, STS has significantly extended 'our understanding of the range of actors and social spaces in which technology can be influenced' (Williams 2002, p. 3). Scientific facts and technological artefacts became 'social', a matter of controversies and interests, things that can be negotiated, influenced and shaped by a variety of social actors and structural conditions. From the beginning in STS, there has been a commitment to 'un-blackboxing' technology, with the aim of finding those same boxes full of new and fruitful insights. Naturally, the insights achieved were sometimes rather controversial (see e.g. Winner 1993).

In the realm of technology research, this new perspective signified a radical shift from the study of societal effects of technology, as typically represented by the work of William Ogburn (1969), to the study of the content and design of technology (Williams/Edge 1996) and the process of technological innovation (Bijker/Law 1992; MacKenzie/Wajcman 1985).

Another long-standing tendency of STS is its commitment to understanding the processes of how science and technology are produced with a view to using that understanding to guide the transformative powers of science and technology in more beneficial and less potentially harmful ways (Spiegel-Rösing/de Solla Price 1977; Edge 1995; Sørensen/Williams 2002; Hackett et al. 2008b). From this perspective, STS is 
strongly wedded to an agenda of social change, grounded on principles and fundamental values such as equality, democracy, and freedom (Hackett et al. 2008a).

Both commitments are reflected in my own work too: the intellectual excitement of examining and explaining technological innovation, and the obligation to support the development of socio-technical systems that address pressing societal problems. With a special focus on sustainable innovation, I intend to contribute to our scientific understanding of subjects such as successful developments, just as I enjoy offering findings that could lead to reconsideration and possibly readjustment of technology policy strategies. In my research I have focused on the role of technology users in technological innovation (see Chapter 2.2), on processes of social learning (Chapter 2.3), and on innovation networks and the role of intermediaries (Chapter 2.4). Although all of the selected articles are based on and partly dominated by empirical research efforts, one pervasive idea in my work is to link findings back to theoretical concepts or at least offer useful metaphors.

\subsection{Technological development in STS}

The unifying idea of technology-focused research within STS, then as now, is to 'criticise and transcend technological determinism - the assumption that technology had an asocial origin and definite, well-defined and predictable outcomes' (Sørensen 2002, p. 20). As a result, technological innovation has become a 'garden of forking paths', offering different routes that may lead to different technological outcomes (Williams/Edge 1996, p. 866).

The efforts to describe and explain technological innovation in STS revolve around (1) a long and rather controversial discussion between agency- (social constructivist) and structure- (social shaping) oriented approaches and the question of how to combine these two perspectives; and (2) the question of how to conceptualise the relation between technology and society. Both strands will be briefly outlined in the following section.

\section{Social construction and social shaping of technology}

It has been argued in the context of the agency-centred social constructivist approach, as formulated by Pinch and Bijker (1987), Bijker (1992), Bijker (1993), Bijker (1995), Kline and Pinch (1996), that technological artefacts and practices are built in a process of social interaction and negotiation driven by the interests of so-called 'relevant social groups'. A key concept here is the 'interpretative flexibility' of technology. This means that different social groups can attribute rather different meanings and even have different understandings of the technical characteristics of one seemingly unambiguous 'thing'. The design of an artefact consequently does not represent the 'one best way', but rather is the result of controversies between different social groups. The artefact stabilises in its final form when negotiations are closed at the rhetorical level.

The social constructivist approach has been criticised for its essentially pluralist view of society (Winner 1993), which implicitly assumes that groups are equal and that all relevant groups are present in the design process (Williams/Edge 1996). In a similar way, Klein and Kleinman (2002) have argued that the social constructivist approach systematically 
overlooks asymmetries of power and the importance of historically established social structures for technological change. However, the social constructivist approach has considerably enriched our understanding of technology by stressing and exploring the ability of a variety of social actors - not only technology producers but also for instance user groups - to influence the design of emerging technologies.

By contrast, structure-centred approaches have focused on political, economic and cultural influences on the development of technology. An early example of such an approach is the work of Gilfillan (1935), who in his Sociology of Invention argues that technological invention is caused, promoted, and steered by social factors and institutions, and not simply by developments in the physical sciences or by industrial practice. MacKenzie and Wajman (1985) draw on this research tradition in their highly influential reader on the social shaping of technology. Based on classical case studies from different disciplines, MacKenzie and Wajman argue that technology is shaped by economic conditions, social relations, the state, and social categories such as class and gender. Klein and Kleinman (2002) have pointed out that even the capacities of social groups to influence the design of technological artefacts are dependent to a large extent on pre-existing structural characteristics.

\section{Integrated approaches to technological innovation}

More balanced approaches to explain technological innovation try to combine and integrate agency and structure-oriented perspectives. Those models also put more emphasis on the time dimension of technological innovation, represented by typical phases of development. Such approaches also make it more obvious that the structural conditions to influence technological change develop over time. In technological innovation processes we may find windows of opportunity that provide ample room to propose and negotiate new solutions, but there are also comparatively stable phases characterised by entrenched technology and path dependency (e.g. as a result of successful dissemination processes).

Weyer et al. (1997) have developed a three-stage model of technological innovation that commendably covers the stages of emergence, stabilisation and societal diffusion, combining the voluntarism of the social constructivist discourse with the determinism of path-dependency approaches (e.g. Dosi 1982). In the three-stage model, technological paths are actively created and shaped by social actors, while at the same time they are limited by the given structural framework of socio-technical options resulting from previous action. Networks are 'regarded as one key mechanism for the explanation of the dynamics of a technological path. Strategic action and interaction in social networks are the driving forces behind innovation and they especially shape the choices at crossroads, especially at the transition between two phases' (Weyer 2006, pp. 4-5).

Werle (1998) has proposed an actor-centred institutionalist approach that is based on the work of Mayntz and Scharpf (1995) and bridges micro and meso-level threads of theorising in science and technology studies. In Werle's approach, 'institutions and actors jointly constitute the social setting which shapes technology' (ibid. 6). Similar to agencycentred approaches, here technical development is seen as 'a result of choices of individual and corporate actors'. But these choices are channelled, framed and contextualised by 
institutions, which are strictly conceptualised as 'systems of rules' (e.g. legal rules, social norms, routines, collective expectations). Since the main aim of this approach is to explain technical development as an outcome of strategic interaction and decision-making processes of (mainly) corporate actors, the focus is on constellations of these actors and how these constellations are shaped by institutional conditions.

Multi-level perspective (Geels 2004) is a recently developed framework to integrate different theoretical approaches. Bringing together the work on transition management (e.g. Kemp et al. 1998; Schot et al. 1994; Kemp et al. 2000), sociology of technology, and evolutionary economics, this model attempts to explain the transformation of large technical systems. The multi-level perspective distinguishes socio-technical transformation dynamics at three levels of aggregation: a micro-level of 'niches' (technological projects, emerging technologies) as a source of variety and an 'engine for change', a meso-level of 'socio-technical regimes' understood as 'semi-coherent set of rules' (Geels 2004: 904) providing stable structures and a selection environment for novel technology, and a macrolevel of 'socio-technical landscapes' as slowly changing socio-technical contexts at the level of societies (Rip/Kemp 1998). One strength of the multi-level perspective is that not only does it explain the resistance to radical innovations that is due to the stability of regimes as a rule set or grammar that structures and coordinates both actors and technologies within functional subsystems of society, but it also provides a concept for the success and dynamics of radical innovations as regime transitions following pressures on these regimes by evolving niches (Weber/Hoogma 1998) or changes at the landscape level (Geels/Schot 2007).

In this framework technological change is characterised by four different phases (Geels 2004). In the first phase, a novelty emerges in an existing context - often to solve local problems. In the second phase, niche actors work on technical specifications and explore new functionalities. If these activities result in a stabilised set of rules (on technical designs, user preferences, rules that constitute markets), wider diffusion of the novel technology can occur, eventually leading to competition with the established regime (third phase). In the last phase, the established regime will gradually be replaced, resulting in wider transformations of the socio-technical regime. Although the multi-level perspective is a structuralist approach, there is enough room to fit in agency-centred perspectives - located at the levels of niche and regime.

\section{Go-production of technology and society}

How to conceptualise the relation between technology and society has always been a crucial question for STS. The assumption that technological development is not autonomous but the outcome of a social process would make it tempting to switch from technological determinism to social determinism. Dolata and Werle (2007) argue that in early social constructivist contributions, technological artefacts appeared to be constituted exclusively by social processes. As a result, the influence of technology upon society has been neglected.

However, in STS there is a long tradition of integrating technology into social theory. Hughes (1986) coined the metaphor of the 'seamless web' to indicate that the evolution of 
large technological systems should be analysed without a prior distinction between social, technical, scientific or cultural elements. Law (1987) argues that technology producers are involved in 'heterogeneous engineering' activities, aiming to control and steer a variety of social and technical factors. Actor-network theory, however, has called for symmetry in the analytical treatment of human and non-human actors (Callon 1986) and therefore has challenged the classical mode of thinking in the social sciences.

Stressing the active role of novel artefacts in innovation processes, Sørensen has proposed to conceptualise 'technology as having catalytic properties' (Sørensen 2002, p. 22). In this understanding, technology 'is seen as an agent that facilitates or makes possible a destabilisation of a given social order by other actors and thus enables the opening of new options' (ibid. 22). Other sociologists of technology have pointed out that novel technology is often enabled by changes in the existing social order. Schmutzer (1994), for instance, argued that technology replaces - diminishing or even collapsing - forms of social cooperation. Rammert (1995) showed that evolving social routines, such as the organisation of work in early factories, prepare the ground for technological innovation.

MacKenzie and Wajman (1999) argue that 'technologies come not in the form of separate, isolated devices but as part of a whole, as part of a system' (ibid. 10). Consequently, existing technology and infrastructure systems should be considered as structural conditions for technological innovation (in a similar way, existing technology is treated as part of the socio-technical regime in the multi-level perspective). New technology is shaped not only by society, but also by already entrenched technology.

In STS, therefore, the relation between technology and society is seen as mutually constitutive. Society shapes technology, and technology enables or hinders social change. Klein and Kleinman are among those who have proposed to analyse technology and society as parts 'of a reciprocal or dialectical process in which each constructs the other' (Klein and Kleinman 2002, p. 35) ${ }^{1}$. In recent years this specific research focus has been characterised as co-production (Jasanoff 2004), co-construction (Taylor 1995) or coevolution of society and technology (Russell/Williams 2002).

\subsection{User innovation: Technology users as agents of socio- technical change}

The 'turn to the users' in STS, as it is sometimes called, can be traced back to Cowan's proposal to focus on the consumption junction (Schwartz Cowan 1987). Cowan argues that user-focused analysis on technology development is a rewarding perspective because all technologies have users, and only by dissemination and use do technologies begin to reorganise social structure.

In a wider sense, users always play a role in technological innovation (for comprehensive overviews see Rohracher 2006; Oudshoorn/Pinch 2003). Contexts and methods of using a technology are far from clear once a technical innovation leaves the

\footnotetext{
${ }^{1}$ Klein and Kleinman (2002: 35) note that in spite of the reciprocal relation between technology and society, it must be possible for the analyst to separate causes from effects. 'At any given point in time, however, it is analytically possible to stop the process and ascertain, at least tentatively, what is affecting what.'
} 
limited social context of design and production. The range of possible roles of users can vary widely, however, from being restricted to what Williams and Edge (1996) have called 'veto power', which means that consumers have no opportunity to engage with the design of technology other than deciding whether to adopt it, to being deeply involved in the design process or even becoming the main source of 'user innovation' - as von Hippel (1986) called it.

This makes STS somewhat ambivalent about the role of users: they are either active and able to shape the design and meanings of an artefact, or passive and reconfigured and shaped by technology. As Shove (2001) puts it, users can be conceptually located within a field of tension - being passively configured by other actors or technology and actively appropriating technologies at the same time.

In our context, the focus is on the ability of users to actively shape the meaning and design of technology. Early users play an active part in negotiating meanings and practices related to an artefact (Mackay/Gillespie 1992). An artefact only acquires its meaning in use. This is what is often called 'appropriation' or 'domestication' of a technological object, how technology is 'incorporated into the routines and rituals of everyday life, the way it is used, and the ways it becomes functional' (Vestby 1996, p. 68). Mackay and Gillespie argue that in their role as users, consumers can be active, creative and expressive.

People may reject technologies, redefine their functional purpose, customise or even invest idiosyncratic symbolic meanings in them. Indeed they may redefine a technology in a way that defies its original, designed and intended purpose. Thus the appropriation of technology is an integral part of its social shaping. (Mackay/Gillespie 1992, pp. 698-699)

In cases of user innovation, the appropriation of technology becomes a broad and transcending activity, obviously 'blurring the boundaries between production and consumption' (Oudshoorn/Pinch 2008, p. 554). Users became 'prosumers', as Toffler has called them (Toffler 1980), which means that they are producers of technology, but still well grounded in the knowledge and the day-to-day experiences of ordinary users.

To what extent users are able to become active designers of technology is indeed dependent on a variety of different factors (we will discuss some of them below), covering socio-demographic characteristics, personal skills, structural and cultural conditions, as well as properties of the technology itself. Therefore is it important to bear in mind that there are different groups of users, which vary in their power to choose the technology, to acquire skills and authority to use it in different ways, to adapt or modify it, to fix problems, override functions or bypass its outputs, or perhaps to subvert or reject it (Russell/Williams 2002, p. 71). Klein and Kleinman (2002) have also stressed the power or capacity of users and other social actors in this context. They argue that the ability of users to shape technology depends largely on structural characteristics, such as economic, political, and cultural resources. Klein and Kleinman assume that among different groups we can find systematic asymmetries of power, and that these differences are rooted in structural conditions of social life.

However, if users play an active role in technological innovation processes, it is likely that the outcome (design of artefacts, functionality, etc.) will be different from cases without 
active users, because in principle technology designers and producers differ from users in their values, interests, knowledge and expertise (Akrich 1995). Sismondo (2008b, p. 22) points out that there are various forms of expertise and 'scientists and engineers may lack relevant forms of expertise when their work takes them into the public realms'. Von Hippel (1998) has shown that users have specific local knowledge that could be highly relevant for defining and solving problems (with their own as the priority) and eventually lead to technological innovations and new market opportunities. Collins and Evans (2002) point out that so-called 'specialist uncertified expertise' from users is integral to the development of the technology, especially in cases of public-use technologies such as cars, bicycles, and personal computers. Users could contribute as 'narrow specialists', broadening the knowledge base, but also just as users or active non-users. This second form of expertise based on experiences as users or non-users of technology is seen as an integral part in establishing meaning and success for new technical artefacts.

Within innovation studies there is quite a long tradition of analysing users as an important source of innovation (see e.g. Rosenberg 1982, von Hippel 1986) (Von Hippel 1988). Drawing on a number of empirical cases from different industrial sectors, von Hippel (1986) has shown that up to 90 percent of all innovations in a field were developed by product users. Of course, in these cases most users had not been individual end-users but firms or organisations. Nonetheless, the point is that these industrial users did act in their 'functional role' as users, rather than as manufacturers or suppliers of products. They provided solutions for their own needs, which eventually became successful innovations.

In some cases, end-users did indeed play a decisive role in early phases of technological development. Technologies such as the personal computer (Allerbeck/Hoag 1989; Schmidt 1997), open-source software (Von Hippel 2001; Tuomi 2002) and sports-related consumer products (Franke/Shah 2003) have been actively shaped or even completely developed by active users. Truffer (2003) has shown that private car users were of decisive importance for the development of organised car sharing in Switzerland.

A well-known example in the field of environmental technology is the development of wind turbines in Denmark (Jorgensen/Karnøe 1995; Karnøe 1996), which was strongly influenced by local cooperatives, in contrast to the more science-based development of wind turbines in the U.S. The Danish bottom-up approach resulted in a rather different development path for both the technology and the supporting social institutions. According to Jørgensen and Karnøe, these differences could even be seen in the 'nuts and bolts' of the different types of wind technology.

In Article IV (User-led Innovations and Participation Processes: Lessons from Sustainable Energy Technologies) Harald Rohracher and I complement these various examples with two case studies on renewable technologies, thermal solar collectors and modern domestic biomass heating systems. These technologies were also strongly pushed by 'self-building' groups, i.e. prospective users who collectively assembled and improved these products. In both cases, strong participation by prospective users gave rise to a series of innovations, and these innovations led to specific design features that were highly functional at a wider level of dissemination. Moreover, in Article IV we discuss a similar case from the construction sector: the collective planning of green buildings by prospective users. These examples are 
instructive for both their similarities and their differences. In all three cases, prospective users cooperated in temporary groups, using similar organisational structures, and in all three examples the activities referred to energy technologies in the household sector. The chosen examples cover planned (sustainable buildings) and unplanned (solar collectors) processes as well as examples from different geographical regions.

Our case studies show that users can be involved in the design and dissemination of technologies at different levels of intensity. Early users can initiate completely new technologies and designs (e.g. a specific type of self-built solar collector); they can find and test new applications of a product (such as solar space heating), be the source of incremental technical changes (such as the control system or additional security components in biomass heating systems), or appropriate unconventional building technologies and design solutions in the course of collective planning processes.

As we discuss in Article IV, such extreme forms of active appropriation and redesign of technology seem to be restricted, and at the same time enabled, by a number of preconditions. First of all, there are technical characteristics that limit the scope and influence of this active mode of appropriation. Technologies appear to be suitable for selfbuilding if they are not too technically complex and do not require highly specialised and expensive tools to fabricate, or if a high level of technical competence is not needed. We also may conclude that the chances for successful self-building are higher in the early phases of technology development and dissemination. At these stages it is much easier to develop solutions that are somehow superior in economical and technical terms to (often immature) commercial products. Collective self-building also depends on a specific and highly motivated user base. We found that besides the practical and individualistic motivations, the work by the organisers and coordinators of such groups can itself be linked to a mission and can be tied up with broader social aims such as 'environmental protection', 'regional development', 'energy saving' or 'using ecological and healthy materials' (similar observations are reported by Truffer 2003 and Jørgensen and Karnøe 1995). We conclude that self-building activities also depend on certain socio-cultural contexts. In the case of solar collectors and biomass heaters, the rural setting already had a tradition of neighbourly help and of co-purchasing and sharing use of expensive tools and machinery in the agricultural sector. In the example of green co-housing projects, however, the activities were rooted in the academic milieu of a German college town.

Article I (Old Technology and Social Innovations. Inside the Austrian Success Story on Solar Water Heaters) presents a more detailed analysis of the extremely successful user-driven dissemination of self-built solar collectors in Austria. Over a period spanning 15 years, approximately 40,000 users participated the numerous self-building groups all over Austria. These activities by self-builders were obviously one of the foundations for Austria's leading position in thermal solar technology today (Ornetzeder/Rohracher 2007). I show in the article that solar heaters only became popular as an environmentally sound alternative during the course of the energy crisis in the early 1970s. The technical concept to build solar heaters for hot water preparation was developed much earlier, however, in the United States at the end of the $19^{\text {th }}$ century. The first patent for a domestic solar heater was granted there in 1891. After notable market success, especially in California and 
Florida, and a series of crucial technical improvements, solar heaters were gradually pushed out of the market by the rapidly growing gas and electricity industry in the 1920s (Ornetzeder 2000). When the first phase of dissemination began in the US between 1895 and 1915, solar heaters represented the only available fully automated technology that could provide flowing hot water to serve the newly emerging domestic needs for personal hygiene. But once the technology was rediscovered in the 1970s, it then had to compete with technical solutions that were already well established. As a consequence, in Austria the first commercial products sold rather badly, and this situation did not change until selfbuilding became popular nationwide. Although self-building of alternative technology was quite common throughout Europe in the 1970s, only in one certain rural region in Austria did it turn out to be tremendously successful.

As I show in Article I, this unique and extremely successful process of dissemination was due to a teamwork-oriented dissemination strategy. In the early 1980s, when the selfbuilding activities began, the strategy was not an intention of early group leaders but rather emerged as a consequence of growing local demand for self-built solar heaters. Initially users developed a way to share the work of building cost-efficient solar collectors in order to serve a very specific demand for additional comfort in rural households in the summer season - a motivation similar to that in the US a hundred years before. These Austrian homes were often equipped with outdated, labour-intensive heating technology (in most cases old-fashioned wood-fired boilers).

The case of self-built solar collectors clearly shows that within a few years self-builders became the relevant social group dominating solar water heaters in Austria. These users were able to change not only the technical design, but also the way in which the technology was integrated into the house and how and for what purpose it was used. Not only was the technology still 'green', as it had originally been perceived in the 1970s, but self-builders had now given it an additional meaning: personal comfort. All in all, these users were responsible for some significant changes to the initial design of solar heater systems, which contributed to a large extent to the incredibly successful spread of solar technology in general.

This brings us back to the question raised by Klein and Kleinman (2002) about the capacity (or power) of groups to shape technology. The authors propose to consider three forms of resources, namely economic, political and cultural. In the solar case, the rapidly growing number of self-building groups led former work-group leaders to create their own group, which later became formally organised as an association focusing on renewable energy in general. The capacity of the core group was mainly based on cultural resources, such as the tradition of neighbourly help and the growing number of groups, as well as the personal mission to promote green energy. Only later were economic resources added by means of membership fees and public subsidies. Moreover, we argue in Article IV that organised self-building substantially profited from 'interaction and mutual completion' (as described in small groups research, cf. e.g. Hofstätter 1986) in heterogeneous groups. 


\subsection{Social learning in technological innovation}

In the previous chapter we showed that under specific conditions users can go far beyond their normal realm; they take matters into their own hands and modify technological artefacts substantially. The concept of social learning we are interested in draws on this active role by users and addresses the interaction between technology development and its appropriation in different use contexts. The focus here is on learning through the sharing and negotiation of different meanings and experiences. Learning is not conceptualised as a narrow individual or cognitive process, but rather as a necessarily social and political practice, entailing technological and institutional change (Russell/Williams 2002).

Social learning stresses that it is practical engagement with technology - its production, use and regulation - that clarifies under which conditions the technology can be used, how users integrate the technology into daily practice, and how accompanying regulations and other measures can be designed effectively. Different social players are directly involved in such processes and they learn primarily by direct interaction.

Such a concept of social learning draws on findings that show that technological innovation does not follow a strict and inevitable succession from invention to diffusion and use. Important ideas for improvements often arise when a technology is already in use, and sometimes these even include radical changes (Bijker 1992; Slaughter 1993; Ornetzeder/Rohracher 2005; Douthwaite et al. 2001). Fleck (1988) coined the witty term 'innofusion' to point out that the innovation of an artefact is not limited to research and development. New and valuable ideas for improvements may arise during implementation and use. Taking the alinear nature of innovation processes into account, Williams et al. (2005, p. 66) have argued that a social learning approach to technological innovation has to be built on a dynamic model, allowing for interactive and iterative processes that involve repeated cycles from the design and development of artefacts to their implementation and use.

The social learning approach in the context of technological innovation builds upon more narrowly framed learning concepts from evolutionary economics and economic history. In this scholarly tradition, learning is seen as a phenomenon with economic significance. 'Learning-by-doing' (Arrow 1962) indicates that the costs of manufactured goods tend to decline as the skills required to produce them accumulate. 'Learning-byusing' (Rosenberg 1982) describes the ability of users to gain familiarity with a given product; as they grow more accustomed to using it, they may give rise to new forms of usage and ideas for improvement. For Steward and Williams (2005), these concepts point to the fact that there is still something to learn about technology, something that is not immediately apparent, something that is discovered only through the process of use and experimentation. It is nonetheless obvious that this kind of knowledge could be important for producers when improving their products or coming up with ideas for new products.

To underline the importance of feedback from users to producers, Lundvall (1988) coined the term 'learning-by-interacting', stressing the importance of channels of information, the development of shared codes to reduce the cost of information transmission and mutual trust as a major condition for learning. He has also argued that the knowledge produced as a result of 'learning-by-using' only can be transformed into new 
products if producers have direct contact with users. This last argument refers to the local and tacit nature of experience-based knowledge. In reference to the work of Polanyi on tacit knowledge, von Hippel (1998) came up with the term 'sticky' information to indicate that it is expensive to transfer a given unit of problem-solving information in a usable form to a given information-seeker.

Social learning stresses the importance of what can be learned in wider contexts of use, and therefore Williams et al. (2005) draw on the concept of 'appropriation' and 'domestication' of technology. Following on this research tradition, Sørensen (1996, p. 5) characterises social learning as 'a combined act of discovery and analysis, of understanding and giving meaning, and of tinkering and the development of routines'. With this definition of social learning Sørensen has tried to capture the complexity of actors, processes and already existing structures, and he points out that the concept of social learning goes beyond classical 'learning-by' approaches in its emphasis on the socio-cultural dimension of innovation. In his view, technological change is conceptualised as a process of social learning and experimenting: 'In order to make an artefact work', he argues, 'it has to be placed, spatially, temporally, and conceptually. It has to be fitted into the existing, heterogeneous networks of machines, systems, routines, and culture' (ibid.). Thus social learning is related to technological change over time; it focuses on both use and design of technology. Sørensen also emphasises that technological change cannot occur in a field devoid of conflict, power or interests.

Keeping in mind the potential that has been claimed for social learning and its effects, Harald Rohracher and I argue in Article II (Contextualising Green Buildings: Improving Social Learning Processes between Users and Producers) that the success of green buildings is put at risk by focusing too narrowly on technological optimisation and expected user behaviour based on constructed 'user images'. We claim that if a mutual process of learning and exchange connects users with technology producers and architects, there can be substantial profit for the development of sustainable buildings in terms of technical improvements and dissemination rates, as well as the buildings' environmental effectiveness. Based on a survey of about 400 occupants of environmentally advanced buildings and a qualitative case study on balanced ventilation systems with heat recovery (one of the crucial components of ultralow-energy buildings), we show that users of green buildings develop their own views and perspectives on energy-efficient buildings and the technologies involved. We also show that different groups of users may develop diverging patterns of use for these technologies and buildings and may attach different symbols and meanings to them.

The case study on balanced ventilation systems made it clear that there are certain user expectations and practical experiences that diverge widely from those of designers and architects. We found controversies between users and designers on the autonomy of users, building automation and mechanisation of housing, and different definitions of comfort. In certain cases, those controversies and experiences fed back into the design of green buildings, leading to a learning process between the different groups of actors involved, where design and use are coupled in a mode of co-evolution.

Based on survey data, we showed that these forms of mutual learning could mainly be found in the context of ecological group-dwelling projects. These group dwellings were 
pioneering projects for green architecture in Austria, succeeding at even extremely uncommon technological concepts. In group-dwelling projects, planning and construction of buildings is typically organised as a multi-year self-organised process of discussions, negotiations and opinion making. Green buildings in other socio-technical contexts (single family homes and large-volume residential projects) with fewer opportunities for learning can also benefit from these experiences, however. In order to show how such learning can be improved in the context of large-volume residential buildings, we outline some basic principles for user participation, covering different stages of development.

Hoogma and Schot (2001, p. 229) had a similar question in mind when they studied learning environments with direct user involvement. Based on two case studies on electric vehicles, they assume 'that user innovativeness does not only follow from de facto use and user characteristics, but also from the quality of the interactions between producers, users and third parties involved'. Users are therefore not inherently a source for improvements. The extent to which users are able to contribute to the innovation process in a profitable way depends on the characteristics of the established learning environment (see Chapter 3).

Vergragt and Brown (2004; 2007) put a special focus on small-scale experiments aiming towards sustainable solutions. They propose a conceptual framework for social learning within what they call 'Bounded Socio-Technical Experiments' (BSTE). A BSTE is

\footnotetext{
an attempt to introduce a new technology or service on a scale bounded in space and time. The time dimension is around five years, while the space dimension is defined either geographically (a community) or by a number of users (small). BSTE is a collective endeavour, carried out by a coalition of diverse participants, including business, government, technical experts, educational and research institutions, NGOs and others. There is a cognitive component to BSTE in that at least some of the participants, and definitively the analyst, explicitly recognise the effort to be an experiment, in which learning by doing, trying out new strategies and new technological solutions, and continuous course correction, are standard features. (Vergragt/Brown 2004, p. 8)
}

Following on the communication approach best represented by Rogers (1995), Vergragt and Brown (2004) conceptualise social learning as a process of diffusion of new ideas and knowledge. Using the concept of 'communities of practice' (Wenger 1998), they argue that the ideas and knowledge generated in BSTEs are transmitted by participants into their own communities of practice. Social learning can then be analysed as a process (and result) of interactions and discourse between new knowledge and knowledge that is already well established. Vergragt and Brown remind us that innovation aimed at sustainability is more complex, and therefore a broader range of actors than users and producers may be involved. Moreover, this specific concept of social learning emphasises different qualities of learning. Vergragt and Brown argue that in BSTEs learning occurs on different levels: On the first level, learning is conceptualised as a problem-solving activity, on the second level as a discourse about the problem definition (with regard to the particular technologysocietal problem coupling), on the third level as questioning of dominant interpretative frames, and finally on the fourth level as a debate on fundamental preferences for social order. Compared to other conceptions of social learning in the context of BSTEs, the range of possible results for learning clearly surpasses the narrow limits of a given technology and provides room to refuse given alternatives and move to completely different solutions. 
Hodson and Marvin (2009) have recently drawn attention to cities as important actors and mediators in technological transition processes. Van den Bosch et al. (2005) and Vergragt and Brown (2007) have highlighted the specific potential of the municipal level as a promising setting for early technology learning processes. In Article $\mathbf{X}$ (Participatory Technology Development and Assessment: In Search of a Sustainable Use of Fuel Cell Technology at the Municipal Level) we explore these potentials further by reflecting on results from a case study on fuel cell technology in the city of Graz, Austria.

The municipal level clearly offers huge potential for social learning processes. For many reasons (e. g. available infrastructure, concentration of stakeholders, clearly defined boundaries, etc.) municipalities can be seen as 'natural' niches for exploring new technologies in realistic use contexts on a limited scale. At the same time, municipalities can profit from environmental and economic benefits by experimenting with sustainable technologies.

The experiences in our case study highlight - in accordance with findings from similar studies - that the implementation of technology learning processes at the municipal level needs to take into account the limited room for manoeuvre of municipalities as well as the importance of the coordination of various governance levels. Municipalities, even if they see themselves as technology forerunners, are limited in terms of funding as well as relevant policies and institutional frameworks.

Furthermore, when dealing with technology learning at the municipal level, it is important to be aware of the multiplicity of roles a municipality may take on in a technology learning process: it can be an early user of a technology, a promoter and funding body, a policy-maker considering longer-term strategies as well as passing relevant legislation, or a combination of these different roles over the longer term. In any case, cooperation with municipalities in niche experiments involves the risk of becoming part of a political debate with an uncertain outcome. Also, while municipal technology learning projects can serve to mobilise stakeholders and thus shape new actor coalitions in the respective innovation field, the effort of coordinating a possibly large number of actors also needs to be taken into account.

In their study on social learning in the application of information and communication technology, Williams et al. (2005) repeatedly point to the importance of intermediaries as key players in social learning. Based on several case studies, they show that intermediary actors link together players from different sites and act as routes of exchange of knowledge and other resources. These intermediary actors may mediate between the different groups involved in social learning processes: users and producers, producers and politicians, research and production. However, although intermediaries are essential for social learning, in wider contexts their possible roles are not restricted to the facilitation of learning and exchange. As Moss (2005, p. 24) summarises, intermediaries are involved in activities such as adapting technologies to contexts of application, translating knowledge into new products and services, connecting people, building networks, lobbying and advocating reform, and raising awareness and broadening perceptions.

In Article VIII (Passive Houses in Austria: The Role of Intermediary Organisations for the Successful Transformation of a Socio-technical System) we analyse the first decades of the 
development of passive houses in Austria by focussing on the role of intermediate organisations (see below). The case of passive houses is interesting, because in Austria the market for passive houses has rapidly increased since the first experiments in the mid1990s. Statistics show that there were more than 4,000 residential units with about 10,000 passive house residents at the end of 2006. Per capita, this is more than in any other country of the world. Because of this success, the fast-growing niche of highly energyefficient buildings seems to have the potential to profoundly transform the existing construction regime, at least in countries like Austria. In the article, we study passive houses as an emerging socio-technical niche by analysing the role intermediary actors have played in social learning processes and in facilitating the growth of this niche.

An important conclusion to be drawn from our analysis is that the socio-technical system that evolved around the concept of the passive house is not a development that was centrally planned, coordinated, or steered, by public policy or by any other single actor. Passive houses have been developed very much from the bottom up, but they have required a high degree of coordination and intermediation: (1) the development of technical and design standards; (2) the creation of a vision and orientation for the further development of the passive house niche; (3) certification procedures for building components meeting the passive house standard to make it easier for users and supply-side actors (such as builders, architects, construction companies, component producers, etc.) to find appropriate components on the market; and (4) the dissemination of information about passive houses.

These processes of social learning are facilitated by a number of organisations of different types: public and private research organisations engaged in energy-efficient building design; private non-profit or commercial organisations, regional or national energy agencies offering energy advice, information dissemination, and support for the growth of actor constituencies; and semi-public institutions such as management agencies for research programmes or stakeholder organisations to coordinate the already stabilised passive house community and lobby for better regulations and support structures.

Furthermore, our case study shows that the evolution and growth of the passive house niche was characterised by a succession of significantly changing intermediation requirements, which could be met by a succession of different intermediary organisations with an alternating focus of activity. In sum, intermediation activities have been a crucial ingredient for the growth of the passive house niche and have been distributed over a large number of organisations in the last 15 years.

\subsection{Innovation networks in the building sector}

The emergence of new forms of cooperation, located between the principles of 'market' and 'hierarchy', has been widely discussed in politics and the public sphere over the last 10 to 15 years. Driven by empirical evidence, the topic has also gained in importance in the social sciences, and a number of theoretical concepts have been developed in order to describe and understand these new phenomena. Most concepts refer to social networks and clusters. Clusters are often studied from an economic perspective. The most important 
theoretical argument is that clusters have the potential to affect competition by increasing the productivity of companies in the cluster, driving innovation and stimulating new businesses in the field (Porter 1980).

In general, social networks are defined as relatively enduring, loosely coupled, individual or organisational systems of action based on mutual trust and interpersonal relations. They are characterised by a common purpose, by the logic of communication and negotiation, and by minimal internal institutional structures. Network members cooperate on a voluntary basis, because the positive effects are considered to be higher than the costs involved (Weyer 1997; Fürst 2001). While different social network approaches may refer more or less to these attributes, there is no common terminology of networks because of the heterogeneous nature of different disciplines and research perspectives (Kaluza et al. 1999).

Social capital (Coleman 1988; Putnam 1993) is considered to be one of the basic principles for interaction in networks. Social capital results from communication, discussions on professional knowledge and values, and the willingness to cooperate. It relies on trust, which serves as a basis for the development of cooperation and mutual support. Social networks operate with governance strategies much more than traditional institutions, which means that they try to influence social action by forming opinions. Governance strategies can be used in networks because it is assumed that the recipients trust the sender. It is assumed that recipients, as partners in networks, are open to advice (Fürst 2001).

In our context, company networks with a focus on technological innovation are of particular importance. Using a socio-historical perspective, Rammert (2000) has shown that innovation networks are a consequence of the limited efficiency of market-based ('creative destruction' as described by J. Schumpeter) and hierarchical (large organisational units, strongly supported by public policy) forms of innovation under the conditions of reflexive modernisation (Beck 1992). In a similar vein, Kowol and Krohn (1995) have argued that innovation networks are a consequence of market and organisational failures. Innovation networks therefore are seen as an opportunity to integrate aspects of technology-push and demand-pull. Networks, especially when technology users are involved, can serve as exemplary markets providing demand-side information relevant for innovation.

Küppers and Pyka (2002) have characterised innovation networks as interaction processes between a set of heterogeneous players producing innovation at different geographical levels. Innovation networks are cooperative relationships aiming at invention, development and successful implementation of products and processes. They are seen as a strategy to cope with uncertain political or market conditions. Moreover Küppers (2002) has argued that cooperation in networks is essential because innovations are becoming increasingly more complex. A new product, for instance, must not only function at the practical level and be economically viable, but also has to fit into the socio-political environment, while at the same time it has to fulfil potential user's specific requirements. Therefore single companies alone are usually not able to summon up enough intellectual, social and material resources to be successful. 
Innovation networks can be used as a medium through which material and symbolic resources are mobilised and combined (Perry 1993). Of course, networks are also seen as structural conditions for social learning (Podolny/Page 1998). Permanent processes of changing, searching, and learning could be stimulated through network interaction, helping to improve the market position of network partners (Hellmer et al. 1999; Williams et al. 2005). Moreover, innovation networks could help to reduce uncertainties in the innovation process if the network partners' various competencies were successfully integrated (Küppers 2002). To summarise, it can be stated that from a theoretical perspective, social networks are considered to be dynamic sources of innovation.

As empirical case studies show, however, ideal-type outcomes are seldom achieved in practical experience. In a German study (Hellmer et al. 1999), the authors conclude that the effects of innovation networks are marginal in comparison to the potential of markets and hierarchy. In particular this seems true for SMEs, a market segment still characterised by distinctive competitiveness that considerably hinders new forms of cooperation. The importance of regulatory and policy frameworks for the success of technical innovations even when they have been produced in effective innovation networks - is demonstrated in a case study on combined heat and power technology (CHP) in Europe (Weber 2005).

Social networks are discussed as a promising solution in the context of sustainable development as well (Majer 2005; Schneidewind et al. 1997). Networks are seen as qualified institutions or new forms of governance to promote normative objectives of sustainability. From this point of view, networks mobilise the potential for self-organisation, bring together social players otherwise separated by traditional institutions, or help to create 'milieux innovateurs'. Majer (2005) has argued that sustainable development is not only a guiding vision but closely connected to the implementation of new governance structures, such as social networks. In a similar way Minsch (undated) has stressed the importance of new forms of cooperation for sustainability, which could not succeed without a broad mobilisation of creative problem-solving potential.

In Article VII (Innovation Networks in the Refurbishment Sector of Austria: Promising Approaches Waiting for Market Success) Jürgen Suschek-Berger and I present two case studies on innovation networks in the field of sustainable refurbishment. Both initiatives are attempts over several years to develop, promote and support innovations for sustainable refurbishment of single-family houses in Austria. Although very close in geographical terms, the two initiatives were developed completely independently of each other. In spite of their separate origins, we found numerous similarities in form and content. In both cases, the network activities are coordinated by rather strong central actors. In addition to network management tasks, these actors are also responsible for several other functions: Public relations, training seminars, strategic development, advisory services for end users, and the implementation of refurbishment measures. The necessity of covering such a wide range of different functions was taken as an indicator of the complexity of innovations in the field of sustainable refurbishment. This was not the story of the development of a new product and its successful launch on the market; instead, the networks had to create several sets of services and products based on new knowledge, skills and technology, which had to be tailor-made at the project level. 
Both networks were driven by the idea of changing practices in the building industry towards more sustainability. They started with the assumption that comprehensive refurbishment of single-family houses offered great potential to reduce $\mathrm{CO}_{2}$ emissions through energy savings. The established networks were expected to close the existing gap between the supply side and the demand side by improving the technical options on offer as well as stimulating demand. These goals were fixed from the outset and were closely linked to the initiators' core competences. These core competences showed strong effects on the development of the networks, so it is not surprising that transfer of knowledge and skills to network partners was one of the strengths in both cases.

Although we could observe that there was much learning taking place on sustainable technology and exchange of practical skills (mainly in the form of professional training), the development of social capital remained at a rather surprisingly low level over the years. In the article we offered two explanations for this finding: First, we posited that it was caused by too many network participants, who at the same time had fewer opportunities to meet on a personal basis. Second, we explained the lack of social capital by the fact that direct competitors (e.g. installers, plumbers or construction companies in a region) participated in one and the same network. Using the example of a local sub-network in one of our case studies, we may conclude that social capital depends on more stable and trustful relations, which in the construction industry can only be built upon project-based experiences of mutual cooperation in small but selected networks.

As our case studies also show, setting up innovation networks does not necessarily lead to market success. We found limitations regarding the demand side and the supply side. On the one hand, the influence on the performance and strategies of network members concerning skills, knowledge and offered products is limited. On the other hand, the analysed networks are not able to open up the market for sustainable refurbishment. Resources for public relations are far from sufficient. To increase the demand for sustainable refurbishments, changes are needed, above all in the regulatory framework. Moreover, the refurbishment market still depends on effective public subsidies for private homeowners.

Compared to successful niche markets, the innovation networks we studied lack not only strong political support but also an effective advocacy coalition. Using the example of photovoltaics in Germany, Fuchs and Wassermann (2008) showed that in terms of market penetration and building up of knowledge, a successful innovation process was substantially supported by a wider network of administrative and academic environmentalists as well as members of environmental social movements and industrial actors, such as manufacturers of renewable energy technologies.

We could also see in the case of passive houses in Austria (Article VIII) that apart from innovation networks, in their more narrow sense as a necessary requirement to deliver wellfunctioning technology on the project level, another major precondition for outgrowing local niches is a wider coalition of diverse players at the local and national level. While there was little top-down and direct steering by the state in the passive house case, public policy and administration still played a crucial role for the success of passive houses in Austria. Here intermediary organisations have successfully managed the interplay between 
public policy, and its responsibility for legislative and regulatory processes and financial support, with the heterogeneous constituency of actors and users needed for the growth of the passive house niche. In recent years, newly established interest organisations exclusively focusing on the passive house concept have coordinated both the already stabilised network of passive house suppliers and lobbying activities for better regulations and support structures.

\subsection{Conclusion}

In this chapter I have presented selected research findings by focusing on three different aspects of technological innovation: actors/agency, social learning processes and innovation networks. The aim of this research is to contribute to our understanding of the dynamics of innovation in the field of sustainability. It is advisable to look at the role of users as innovators in processes of social learning or structural aspects of innovation networks, since their role is not only of scientific interest, but also becomes relevant when we intend to use research findings to reflect and guide innovation management strategies. In fact, some of the knowledge we derived from our case studies was quite helpful in setting up projects that sought to involve users in ongoing technological developments (see the following chapter).

Our case studies on user innovation have clearly shown that self-building, when it is organised in temporary groups rather than as an individualised do-it-yourself activity, is a powerful source for technological development. Users in our cases came up with significant design changes as well as new applications. Most of these improvements found their way to commercial producers later on. As a result, Austria is the leading exporter of solar thermal technology in Europe today. The analysis of such extraordinary cases (successful in terms of improvements in design and dissemination of technology, with far-reaching impacts) show what we can expect from active technology users: they can precisely name their problems; they add new meanings to artefacts in use; they tinker with novel technology and improve the design, eventually finding new ways to integrate it into existing systems; and they discover new ways of using a given technology. Such extreme forms of (end-)user innovation as we have presented here, however, depend on certain structural conditions. In many cases, user-driven innovation is a kind of reaction to insufficient offers on the market. Moreover, these innovations are certainly dependent on various cultural and economic resources - often available only in very specific local contexts. Given such conditions, users are able to provide both 'narrow specialist' as well as 'broad uncertified expertise' to technological innovation.

The concept of social learning takes the specific expertise of users for granted in general - not just in cases of user innovation - and addresses the interaction between technological development and appropriation in contexts of use. In the case of 'green' buildings, we have seen that early users obviously express distinct views and perspectives on novel technologies and possibly develop diverging patterns of use. This kind of information is of decisive importance for technology producers, especially in early phases of development. However, the extent to which relevant information can be transferred to technology producers (in our 
case architects, builders or energy experts) is also a matter of structural conditions in the building sector. We found that group-dwelling projects provided particularly effective learning environments. On a general level, we can conclude that effective learning environments should help users to pinpoint problematic issues and should offer various possibilities for direct interaction between users and producers. Intermediary actors, as information brokers between producers and users, can certainly play a central role in this regard. In our study on passive houses, we reconstructed different forms of intermediation that enabled social learning for this specific case. One thing that became clear was that successful intermediation had to be able to adjust to changing requirements over time and needed to be extended to an increasing number of different organisations once niche experiments had reached a national level.

The third focus in this chapter is innovation networks. I have presented two case studies from the field of sustainable refurbishment of residential buildings. It is a fact that the existing building stock offers huge potential for more sustainability that goes beyond cutting back on household energy consumption. Recent research on life cycles of buildings has shown that, in many cases, refurbishment is the more sustainable option as compared to replacement by new construction (Klunder 2005). Innovation is needed in Austria, especially in the single-family housing sector. The number of refurbishments in this sector is low, and when projects are realised, if at all, they are still dominated by single-step procedures. Such procedures hinder the realisation of comprehensive and ecologically effective concepts. The establishment of innovation networks, with their purported ability to cope with such complex and difficult tasks, should be the appropriate strategy in this situation. Our case studies have shown that the network initiatives in fact must cover a wider range of different functions and roles, since innovation in this case implied not only developing new technology and products, but also creating several sets of services, finding appropriate suppliers, improving the skills of craftsmen and delivering tailor-made solutions at the project level. However, our cases have also shown how difficult it is for the central agency to accomplish the huge variety of different tasks. Among other things, we found that a large number of network participants is indeed helpful to stimulate mutual learning processes, but at the same time it can hamper the establishment of social capital - a major precondition for cooperation and mutual support in innovation networks. 


\section{Experiences with and reflections on TA exercises}

In recent decades technology assessment (TA) has become a broad field, covering diverse approaches, aiming at different objectives and applying an astonishing number of methods (Grunwald 2002a; Joss/Bellucci 2002; Meyer 1999; Van den Ende et al. 1998). TA started in the 1960 s as a new approach to interdisciplinary policy research, focusing on early warning, risks, and unintended or undesirable consequences of new technology. Van den Ende et al. (1998) label these early, expert-based forms of TA the 'traditional' approach. Here, the aim was to provide expertise by interdisciplinary groups of experts to policy makers. By contrast, the 'modern' forms of TA are characterised as more process-oriented, more open to including various forms of expertise as well as different social players or even the general public. ${ }^{2}$

One way to deal with this fruitful but sometimes confusing plurality of TA approaches is to take a closer look at the main problems and limitations modern forms of TA strive to overcome. On the one hand, we can find strategies dealing primarily with the 'Problem of Legitimacy' in technical decision-making, as described by Collins and Evans (2002). Most participatory TA (pTA) approaches belong to this first group. Here, a central idea is to improve the democratic basis of technology related decision-making (Joss/Bellucci 2002). Approaches in this category are commonly referred to as public TA. On the other hand, there are TA approaches that primarily aim to broaden and hence to enrich the knowledge and value base of ongoing technological innovation processes. The overall goal here is to improve technology, achieving more reliable and otherwise 'good' technology, as Rip et al. (1995a) call it, by stimulating social learning and experimentation. The most prominent example of this second group is constructive technology assessment (CTA), which was mainly formulated in the Netherlands (see next section). A similar concept, called innovationsorientierte TA (innovation-oriented TA) (Steinmüller et al. 1999; Bröchler/Simonis 1998), was developed in Germany but had much less effect on the international discourse on TA.

In my own work, I have repeatedly taken up the challenge of being involved in ongoing technological developments - even if only in the context of research projects, and therefore in a rather limited way. Article III reports on the participatory assessment of sustainable housing concepts using focus group discussions. A similar approach was used for an interdisciplinary project I participated in on sustainable wastewater technology. In this case, future users were confronted with a pool of diverse options and asked to discuss acceptance as well as acceptability issues (Article VI). Article X provides an example of the participatory development and evaluation of sustainable applications for fuel-cell

\footnotetext{
2 This does not mean that expert knowledge is of less importance for TA today. The distinction between 'traditional' and 'modern' should be understood as a way to characterise the enormous differentiation that the field of TA has gone through in recent decades. As Bechmann et al. (2007) have argued, there is still a demand for scientifically based, research-oriented consultancy, and hence the classical TA approach has been significantly developed as well. A good example is the concept of rational TA (Grunwald 1999): In this concept, participation of stakeholders or citizens is explicitly not provided. Assessments of intended and unintended consequences of novel technology are instead the outcome of a rational discourse of crossdisciplinary groups of experts.
} 
technology at the municipal level. In Article IX, the final in this chapter, we present and discuss recent experiences with a non-expert conference on end-user energy technology in Austria. This is the only example in this collection where questions of political legitimation were of greater importance. In all of these cases, I was involved in the conception and organisation of the research and the analysis of results. Most of the articles in this collection report on experiences applying various forms of process-oriented types of TA. The main reason for taking up an a priori pro-innovation position in these cases was the explicit orientation towards sustainability. Here, one can assume that there is a broad political consensus on the general direction of future developments (Rip et al. 1995b). TA consequently could shift its focus from expert-based assessments to more discourse-oriented learning processes. Before discussing my own examples in more detail, I will briefly relate the theoretical and methodological background of these participatory TA activities.

\subsection{The constructive technology assessment (CTA) approach}

The development of CTA was closely linked to the institutionalisation of TA in the Netherlands. The idea of broadening the decision-making on science and technology in society was first launched in a government white paper in 1984, using the programmatic title Integration of Science and Technology in (quoted in Schot/Rip 1996, p. 252). When the Netherlands Office of Technology Assessment (NOTA, now the Rathenau Institute), was founded two years later, one of its first tasks was to develop CTA as a new, more participatory and discursive approach. In the beginning, CTA was not intended to replace classical forms of TA, but rather to broaden the focus of analysis and to add a new set of instruments to the 'toolbox' of TA (Van Boxsel 1994). In the 1990s, however, CTA increasingly became an umbrella term that stimulated discussion on how to reformulate the way technological innovation is managed by society in general (Rip et al. 1995a).

Schot and Rip define CTA as 'a new design practice (which includes tools) in which impacts are anticipated, users and other impacted communities are involved from the start and in an interactive way, and which contains an element of societal learning' (Schot/Rip 1996: 255). In CTA it is of major importance to stimulate a broad discourse on (novel) technology that brings together all relevant parties, even technology opponents. Designers, users, citizens, policy makers and others should be able to articulate ideas and values quite early and negotiate and renegotiate important aspects throughout the course of the technology development process. The term 'constructive' indicates that those activities are directed at the design, the construction, the application and effects of the technology, and that all those affected and involved in the development are responsible for the outcome (Schot 2001). It seeks to open the design process at early stages in order to discuss probable effects - both negative and positive - before they become entrenched in society, and to find alternative development pathways. Hence CTA could be understood as a strategy to deal with the 'control dilemma', as introduced by Collingridge ${ }^{3}$ (1980).

\footnotetext{
${ }^{3}$ In his well-known book, The Social Control of Technology, Collingridge summarises the dilemma of control as follows: 'attempting to control a technology is difficult, and not rarely impossible, because during its early
} 
As does TA in general, CTA aims to support the development of technologies that have desired positive impacts and few or at least manageable negative impacts (Rip et al. 1995a). In the long run, however, CTA purports to fundamentally change the way technologies are produced in modern societies, often described as a two-track approach where activities to foster technological innovation are institutionally separated from activities to control it. The general idea of CTA is to 'manage technology in society' by narrowing the gap between innovation and the societal evaluation of new technology and by putting technology on the socio-political agenda. CTA therefore has to integrate the anticipation of technological impacts with the articulation (and promotion) of technology development itself. The co-production of impacts must become reflexive, i.e. actors - whether they see themselves as "promotion" actors or "control" actors - must realize the nature of the coproduction dynamics, and consciously shape their activities in terms of shared responsibility' (Rip et al. 1995, pp. 3-4). It is on this account that Rip and Schot coined the saying that CTA is about 'better technology in a better society'.

As the focus of CTA is on the management of technological innovation, normative criteria to assess technology are not included in the concept. A shared definition of 'better technology' in a specific context is not given from the outset, and seeking out what constitutes better technology is part of the process itself. This of course engenders some uncertainty about the substantive outcomes of CTA activities. Since broadening the design process should enrich the discourse and improve the quality of the results, Schot (2001) argues that the performance of CTA should be monitored using three process-oriented criteria: (1) anticipation, defined as the opportunity for involved social groups to be able to define problems by themselves and take long-term effects into account, (2) reflexivity, a dimension to measure the ability of social actors to consider technology design and social design as one integrated process, and (3) societal learning, a criterion to assess to what extent first-order learning (the ability to articulate user preferences and regulatory requirements and to connect such conclusions to design features) and second-order learning (the ability to question existing preferences and requirements in a more fundamental way and perhaps come up with very different demands or radical design options) has occurred. These criteria are intended to monitor whether the design process itself is changing, or whether a modulation of the network and actual content of the interaction is required. Referring to the work of Decker and Ladikas (2004) Van Merkerk (2007) argues that the overall effects of CTA activities should also be assessed in terms of the achieved knowledge uptake and use. Researchers would observe the amount of information absorbed, the changes in previously held views and any changes in the actions of participants. In every case, CTA requires appropriate internal or external monitoring activities in order to assess the achieved effects during the process. ${ }^{4}$

stages, when it can be controlled, not enough can be known about its harmful social consequences to warrant controlling its development; but by the time these consequences are apparent, control has become costly and slow.' (Collingridge 1980, p. 19)

4 Van Merkerk (2007, p. 187) has proposed an evaluation scheme that comprises three phases: ' 1 ) assessing differences in interaction processes during the workshops, 2) assessing differences in broadening and enriching afterwards, and 3) constructing attribution stories'. 
A brief outline of CTA would be incomplete without mentioning strategies to apply CTA in practice. In their paper from 1996, Schot and Rip propose pursuing CTA through (1) technology forcing, (2) strategic niche management and (3) stimulation (or creation) of alignment. While technology forcing, e.g. by means of governmental regulation, has remained rather marginal in the CTA context, strategic niche management (SNM) has become a well-elaborated concept. SNM (see e.g. Hoogma et al. 2002; Weber et al. 1999) refers to the creation and growth of protected spaces for promising technology. A central aim of the development of niches is to enable learning in realistic social contexts (e.g. market niches, controlled field experiments) about the needs, problems and possibilities of the technology under experimentation, and to help articulate design specifications, user requirements or unexpected side effects of the innovation. Strategic niche management is undoubtedly one of the most comprehensive and advanced forms of managing technological innovations through the organisation of social learning processes, involving producers, technology designers and users in a joint long-term process. The third generic CTA strategy focuses on the interactions as such and attempts to create and exploit loci for alignment. The 'loci for alignment' strategy attempts to create institutionalised linkages between supply and demand, since it should be possible for a variety of heterogeneous social actors to interact and learn from each other in a constructive way. All of our own case studies presented in this collection, and most of the other published CTA activities, belong to the 'loci for alignment' strategy. Van Merkerk (2007) recently proposed the 'constructive intervention' concept, based on the 'loci for alignment' variant of CTA, as a particular strategy to improve the quality of innovation processes by broadening and enriching them.

From the beginning, the constructive approach to TA has been strongly influenced by insights from science and technology studies (STS). In this context it has been argued that technology does not develop as a result of some inner logic, but rather as a function of social, economic, technical, and political factors (see previous chapter). Bijker has argued based on empirical case studies that relevant social groups contribute to the construction of technology, and that there are no criteria to attribute a special status to specific actors or social groups (Bijker 1995, p. 288). In a similar but less strict way, Collins and Evans (2002) have pointed out that laypeople have contributory expertise that shapes the future design, form and function of public-use technologies. In all cases, users or active non-users of technology are seen as integral to the establishment of meaning and success. It is because of this reasoning that GTA proponents support broadening the decision-making process on technological innovation by including all relevant societal actors. Since technology is somehow socially constructed, CTA strategies should help to make these decision-making processes more transparent and symmetrical and to have them incorporate social concerns as well as additional forms of knowledge.

However, the possibilities to influence the design of technology change considerably over time. Based on the work of Nelson and Winter (1977), researchers have described technological development as a quasi-evolutionary process, with phases of variation, selection and retention (e.g. Weyer 1997; Tushman/Rosenkopf 1992). In the early phases, when a variety of options exist, there is 'interpretative flexibility', as Pinch and Bijker (1987) 
have called it, which means that relevant social groups may ascribe very different meanings to one and the same technical artefact. It is the responsibility of these social groups to articulate problems and decide which solutions may be accepted as appropriate. From a social constructivist point of view, technological development is by its nature a controversy that resolves as meanings become more homogeneous and therefore stabilised. As controversies resolve and technological variations are selected, possibilities to influence the development are shortened. As Collingridge (1980) shows, technology becomes more and more entrenched in its use context and often ends up as a rather stable part of sociotechnical infrastructures.

These insights have at least two consequences for CTA: First, there are 'preferred loci for influencing' (Rip/Schot 2002), which could be detected and used for intervention, and second, there are stable phases characterised by entrenchment and path dependency. In order to be able to identify such 'preferred loci' for intervention, CTA practitioners placed great importance on understanding the dynamics of technological developments. For just this reason, even the first CTA projects at NOTA included research activities that provided an up-to-date overview of most relevant social actors in the specific technology (a 'sociotechnical map') and included a survey of current trends and a technology forecast study (Van Boxsel 1994). We should keep in mind that the effectiveness of constructive interventions is highly dependent on questions of timing and choosing appropriate social contexts. Looking at emerging technology just before it 'gels', as Rip terms it, may still allow time to exert some influence. On the other hand, even the path dependency during stable phases is seen as an opportunity to manage technological innovation. If CTA activities are used 'to shape the path and its ensuing dependencies at an early stage', or so goes the argument, 'there is no need to interfere later on' (ibid. 166).

Research in CTA is also contributing to the question of how to define and predict the impacts of future technologies. If technology is socially constructed, its impacts are open to diverging interpretations as well. As Sørensen (2002, p. 32) points out:

\footnotetext{
We have a fragile basis of predicting 'impacts' because the interpretations of technologies are dynamic and situated, and thus inherently flexible. Not because technologies are flexible in a material sense, but because it is of great importance what people that relate to a given technology make out of it. Meaning and praxis is [sic] not predetermined at any stage. They are produced through controversies, negotiations, and truces, although in a contingent manner.
}

Thus CTA treats the impacts of technology as dynamic, as involuntarily co-produced during the implementation and diffusion stage. CTA researchers also argue that societal consensus on which impacts are desirable is rarely present and/or achievable (Rip et al. 1995a). Because of this dynamic nature of technology impacts, CTA is conceptualised as a process of learning and experimentation (Grin/Graaf 1996). Possible impacts are to be discussed and anticipated earlier and more frequently (Schot 2001). Technology assessments are seen as integrated and repeated parts of the innovation process, applied at preferred loci for intervention. 


\subsection{CTA activities and case studies}

The first CTA projects were established shortly after the founding of the Netherlands Organisation for Technology Assessment. In those first few years (1987-1991), the agenda featured topics such as ISDN, smart housing/home automation, biotechnology and genetically-modified organisms (Van Boxsel 1994). Ideas from CTA also influenced the Dutch Sustainable Technology Programme (DTO), which started in 1993 as the first research programme on sustainable technology development in Europe. In practice, however, it turned out that the DTO was primarily technology-oriented, and in most of its projects users and citizens did not participate at all (Schot 2001).

One rather successful example where the CTA-inspired interventions did work quite well (Quist/Vergragt 2006) was a project on novel protein food. With the idea of creating a nexus between producers and users to stimulate reflexive learning, the Dutch Institute for Strategic Consumer Research developed a method called Future Images for Consumers (Fonk 1994). In a series of meetings, representative organisations spoke as advocates for future needs of consumers and the environment. There was considerable follow-up (Quist/Vergragt 2006) in this case, and as a direct consequence a huge research project was carried out that dealt with the technological, socio-economic and cultural issues of the production and consumption of novel protein food. At a more general level, the topics of novel protein food and other meat substitutes were incorporated into the sustainable consumption activities of the Dutch Ministry of the Environment.

Recent examples of CTA activities focus particularly on the stimulation and creation of alignment in the context of research projects. Heiskanen (2005) reported on experiences with a CTA approach to the search for sustainable alternatives for online grocery shopping, bringing together a broad spectrum of social players and covering technology proponents as well as opponents. Although Heiskanen's experiment did not lead to immediate 'real-world' changes, the outcomes show that 'the attempt to create better alternatives together helps to create a space for dialogue between different technology discourses' (Heiskanen 2005: 69). Van Merkerk and Smits (2008) presented a three-step approach to better support the roles that participants play in the innovation processes of emerging technologies. The main idea of their approach is that relevant social groups should be empowered to develop group-specific future scenarios before these individual scenarios are discussed and exchanged with all participants: In the first step, comprehensive information is provided to all participants. Based on this information, in the second step each participating group constructs its own individual scenarios. Only in the third step are these well-prepared individual scenarios presented and discussed among the different groups in dialogue workshops. Van Merkerk and Smits applied this method within a study of lab-on-a-chip technology in the Netherlands in organising four dialogue workshops with about 50 participants. In the work of Roelofsen et al. (2008), a specific GTA approach aimed at involving end-users (Interactive Learning and Action) was combined with vision assessment in order to discuss desirable futures for ecological genomics from multiple perspectives, starting with the visions of technology promoters. 


\section{Fuel cell technology at the municipal level}

In our case study on fuel cell technology (see Article X, Participatory Technology Development and Assessment: In Search of a Sustainable Use of Fuel Cell Technology at the Municipal Level), we chose CTA as a methodological frame for designing a discursive process aimed at exploring and assessing possible social contexts for the use of fuel cell technology in Austria. Fuel cell technology has long been seen as an alternative to other decentralised energy supply systems with notable ecological potential. Although there have been many research efforts to improve fuel cell technology, its fields of application and the institutional settings where the technology could contribute as part of a sustainable energy system are still not clear (Eames et al. 2006).

During the preparatory phase of the fuel cell project, we conducted a series of interviews with national technology experts, representatives of companies active in this field, and potential users. We also consulted the relevant literature. This background study served to map the innovation field of fuel cell technology in Austria (socio-technical mapping). As a result of this research, we decided to focus our main study on potential future applications of fuel cell technology at the municipal level, which we had identified in our background work as a promising locus for intervention. Municipalities could profit from fuel cell technologies in ecological terms (reduction of local emissions) and at the same time could be considered as technology users (having a hydrogen-driven local bus fleet, for example).

Although municipalities are strongly dependent on larger-scale developments at the national and international level, they are able to provide a significant push to the application, regulation and maturation of emerging technologies (Brand 2005). Indeed, enabling niche-learning processes in relation to the use of new technologies has been highlighted as one of the most important conditions for kicking off transformation processes (Hoogma et al. 2002). Municipalities or regional authorities may contribute to such nichelearning processes by the implementation of pilot projects or permanent installations (the municipality as 'early adopter'), for example, but they may also do so by acting policy makers, promoters or sponsors of technological development.

The discursive part of this project consisted of a series of workshops with three consecutive meetings. The three workshops were attended by a total of 16 experts and stakeholders. Most participants consisted of experts in fuel cell technology (R\&D actors from basic research and industry), with only a few intermediary organisations and one representative of the municipality taking part. The workshops followed a bottom-up approach, using various interactive techniques, group work and plenary discussions to develop and assess different scenarios and analyse strategy.

The internal evaluation of the process, in the form of an analysis of minutes and an expost survey, indicates that the applied workshop design significantly encouraged the anticipative, reflexive and social learning capacities of the actors involved (mainly based on reported self-assessments by workshop participants). These evaluation results largely matched the substantive outcomes of the workshops. Participants identified various plausible application areas for fuel cell technology, re-emphasised some of the most pronounced potential uses as well as the unsolved problems of fuel cell technology, 
prepared a qualitative sustainability assessment of possible application areas, and finally critically reviewed requirements for municipal pilot projects in the future. However, it also became clear that fuel cell technology, or any other emerging and therefore less mature technology, is not the first priority for municipalities when they are in search of sustainable alternatives as technology users.

Assessment of new building concepts by experienced users

In Article III (Sustainable Technology and User Participation. Assessing Ecological Housing Concepts by Focus Group Discussions), I use focus groups to discuss experiences with participatory assessments of sustainable housing concepts. We had the opportunity to cooperate with two R\&D projects carried out within the framework of the Austrian research programme 'Building of Tomorrow'. Both of these projects dealt with radical new concepts for largevolume residential buildings, and both were trying to develop very different ideas for comprehensive sustainable solutions (first case: ultra-low energy concept; second case: ecologically sound materials and flexible-use concept). The aim of our exploratory project was to bring together experienced users of ecological buildings with architects and energy experts. The design of the intervention was based on the idea of establishing a nexus between users and producers of technology, even during early phases of development, in order to identify demand and discuss acceptance and acceptability issues that often constitute substantial and underestimated barriers to innovation.

Focus groups are a well-established method in empirical social research. One strength of this method is that it can provoke a broad spectrum of ideas and opinions (Stewart et al. 2007), an important ingredient for technology learning. The group situation stimulates participants to add additional arguments and ideas. It also provides a kind of spontaneous peer review for given statements. However, the way participants are recruited is of major importance if reasonable outcomes are to be achieved (see also Chapter 4).

The two focus group discussions in the sustainable-building case showed clearly that it is feasible and worthwhile to let experienced users evaluate housing concepts from their point of view even at a very early phase in development. Even though neither plans nor models of the planned buildings were available, and these concepts thus existed merely as narratives given by the responsible project leaders, the participants came to grips with the concepts relatively swiftly by means of well-targeted questions. Participants were able to name conceptual deficiencies rather quickly and came up with a number of suggestions for improvement on the basis of their experiences with green architecture. They were able to evaluate the concepts independently of their personal interests, particularly since they themselves would never live in the newly planned buildings. Based on the overall outcomes, we were able to differentiate three kinds of results: concept assessments, desired qualities and illustrative reports involving users' individual experiences. The observations made during the discussions were for the most part constructive comments, able to inform and support the further development of the new building concepts. This was possible because both groups were formed using an elaborate selection process. All participants had several years' experience with and a special personal interest in environmentally friendly architecture. We also paid attention to gender balance. Despite the positive quality of the 
results gained in our case, I assumed in the article that it would be advisable as standard practice to carry out at least two or three focus groups, with different participants in each case, to get a broader and therefore richer base of arguments.

Gombining expert-based and discursive forms of TA: The case of sustainable sanitation technology

Article VI (An Integrated Assessment of Options for Rural Wastewater Management in Austria) reports on a recently finished interdisciplinary TA project on rural wastewater management in Austria. The starting point for this project was the fact that even in highly industrialised countries, there is a large need to upgrade inadequate wastewater management facilities in rural areas. This urgent need to replace existing solutions creates a window of opportunity for the development and application of new systems that are ecologically as well as economically advanced.

The objective of the project was to study alternative wastewater management options based on the separation of wastewater into its constituent parts, and to compare them with conventional (sewage networks) and other alternative options (e.g. compost toilets). The applied integrated assessment approach covered economic, social and hygienic aspects, as well as environmental risk. Further, an analysis of the relevant legal material was carried out in order to assess any legal constraints on applying alternative options. Since economic comparisons are highly dependent on realistic conditions, the assessment of costs was carried out as part of six feasibility studies in selected rural areas. In three out of these six case study areas, we had the opportunity to present and discuss with local citizens a portfolio of planning options that was based on the results of the expert-based assessments.

An interesting aspect of this project was that we were able to design the discursive part so that would both aid in learning more about the social acceptance of new wastewater management options in general and support ongoing decision-making processes in the case study municipalities. In order to get qualitative feedback on several new technological options, we decided to carry out presentations and discussions on location with all concerned residents. Based on a broad 'pool of options' for each case study, the most appropriate options were selected and presented to a group of citizens who represented public expertise in public-use and local-interest technologies (Collins/Evans 2002). All directly concerned homeowners were invited by the municipalities to attend the presentation. In all three cases, the participants covered most of the concerned population.

The setting was similar to the focus group method: Each meeting started with some general information on the research project, followed by a presentation of possible wastewater options for the planning area. After these presentations by project staff members, the audience could raise questions; these were followed by discussions on the technical options presented. Finally, a concluding assessment of options was gathered by means of a written questionnaire.

Our results once more demonstrated that social acceptance of new technology is closely linked to specific social contexts. Technological options such as separating or compost toilets, which demand major behavioural changes, showed significant problems regarding social acceptance. Yet the systems that allowed the separation of grey and black water 
(known as 'separation-light') were seen as very attractive solutions. This can partly be explained by the fact that those systems are already used in the area to some extent. Moreover, these technologies could easily be combined with constructed wetlands - a widely accepted option in this region - and, compared with other options, such separationlight systems are fairly cost effective in the long run. Despite some significant differences regarding the presented options, in all cases the concerned population was very aware of the importance of improving or replacing the existing wastewater system in their region.

In the article, we conclude based on the group discussions that options which provide full separation of all wastewater fractions should be considered with care, whereas options based on the separation of only grey and black water or water in the liquid/solid phase should seriously considered as alternatives. It is most likely that concerned homeowners in rural areas will accept these latter options, which offer significant ecological and economical advantages over conventional systems.

\section{The future of end-user related energy research in Austria}

In Article IX (Participatory Assessment of Sustainable End-user Technology in Austria) we refer to experiences using a participative technology assessment (pTA) approach to discuss and evaluate research and development goals for sustainable energy technology in Austria. While there is a tradition of involving stakeholders in technology-related decision-making, laypeople have not been widely included in the Austrian context up to this point (Nentwich et al. 2006). The article is based on the project Future Search \& Assessment (Nentwich et al. 2008) on behalf of two Ministries and the Austrian Council for Research and Technology Development, and it was carried out at the Institute of Technology Assessment.

The project team developed a tailor-made process combining elements of vision assessment with an innovation-oriented TA approach. In order to link the project as closely as possible to ongoing research activities, the team decided to use the recently launched national R\&D programme 'Energy of the Future' (more precisely the chapter focusing on future end-user technology) as its starting point and subject matter. In the main part of the project (a two-day conference in November 2007 intended for laypeople), 36 laypeople selected per representative quota discussed the future of energy research in Austria on two different levels: general visions of sustainability and deduced short-term aspects regarding the present end-user related energy research agenda. The strategy chosen consisted of a well-balanced mix of plenary sessions, expert inputs, and moderated working groups. Assisted by external experts, the participants had the opportunity to discuss and give their recommendations on five different research topics: (1) micro-cogeneration systems (microCHP) for end-user markets, (2) completely new system solutions and avoidance strategies at the household level, (3) smart metering and 'intelligent' end-user equipment, (4) innovative contracting and leasing models, and (5) visualisation and monitoring devices. All of these topics are seen as important elements of a more sustainable future energy system, and hence the successful implementation and diffusion of related products is of high importance. For this reason, the perception of possible products derived from research by possible users was a critical point of our conference. 
The chosen conference design made it possible to discuss various aspects of future technologies in detail. Laypeople came up with a list of recommendations that covered general aspects of social acceptability as well as requirements derived from more individual orientations (e.g. usability issues). Laypeople therefore contributed as end-users with specific experiences, habits and attitudes. The conference produced a broad range of recommendations, and a considerable number of new aspects came to light. Most of these results may be seen as the outcome of 'political will formations' (Brekke/Eriksen 1999), practical judgements based on broad and well-balanced information and discussion. The results also show that laypeople clearly support the idea of mission-orientated innovation policy, believing that research and development in the energy sector should lead directly to solutions to mitigate climate change. However, citizens are at the same time very aware that problems of the future cannot be solved by technological innovation alone. New technology should be embedded in wider socio-political contexts, such as changed price relations and new consumption patterns.

\subsection{Conclusion}

The four examples presented in this section are linked by the idea that technological development can be modulated in a socially desirable way by including stakeholders and laypeople in the design process. In all of these cases, the concept of CTA served as a direct or indirect guideline for setting up appropriate designs for anticipation and intervention. The 'loci of alignment' variants of CTA were applied, since all cases dealt with sociotechnical concepts in early phases of development.

The events and workshops were designed to enable the active participation of technology users. The question of how to involve non-experts, users and citizens (see Schot/Rip 1996; Genus/Coles 2005) in our context was solved by using focus group discussions (to give us access to specific user groups) and, as described in Article IX, by using a conference designed for laypeople (aiming at a broad representation of possible users and non-users). Bringing potential users together and confronting them with technological concepts or visions in a discursive way was certainly new - at least within the Austrian context.

Our cases underline the importance of identifying preferred loci for intervention. The workshop series on fuel-cell technology, for example, was designed to support the reorientation of a technology research programme. Similar timing was applied to the conference on sustainable energy technology for laypeople: outcomes of this conference would be used along with other data to inform a newly established research programme. In the sustainable building example, the focus groups were scheduled to occur after the development of the new building concepts but before the assignment of further project phases. In the case of the sustainable sanitation technology, changed regulations stipulated that the municipalities concerned had to come to a decision by a certain deadline, and the intervention took place before this point. In all cases, the topics, scope and timing were selected in order to maximise potential impacts on technological development. However, as other examples show (Heiskanen 2005, Van Merkerk 2007), the use of 'loci of alignment' 
variants of CTA in early phases of the development did not result in direct impacts. Even if such direct impacts occur in the future, it would be rather challenging to track them. This kind of CTA certainly is not an instrumental method to reach specified outcomes. Instead, as Heiskanen (2005) points out, it is a strategy to create new discursive spaces where experts, stakeholders and citizens can work together on envisioning better alternatives. As our examples show, the strength of those interventions lies in the alignment of diverging perspectives, ideas and expectations. 


\section{Research Strategies and Methods}

The results presented in this collection are based to a large extent on empirical studies. The material was collected within a number of research projects over the last ten years. In these research activities I was involved in different ways: as project leader (II, III, IV, V, X), as social scientist in an interdisciplinary team $(\mathrm{V}, \mathrm{VI})$, or as a member of a research group, responsible for empirical surveys (I, IV, IX). The research was conducted in various team constellations and different project consortia, funded by a range of mainly national sponsors.

Table 2 gives an overview of the research strategies, designs, methods and empirical data used in the presented articles. All in all, the results discussed in the papers are based on 980 standardised face-to-face interviews (or returned written questionnaires) collected in five different surveys, 92 semi-structured interviews, five focus group discussions with a total of 52 participants, and three workshops covering 64 participants.

Of course, the articles do not reflect the whole richness of all the collected material. The reasoning in the papers often is focused on specific questions and phenomena, and hence the underlying empirical studies are sometimes used in a rather selective manner.

In the following I would like to highlight three aspects of my empirical work that point to major challenges and achievements in this specific field of investigation located between technology research and assessment: combining qualitative and quantitative methods, performing research in multi- and interdisciplinary contexts, and creating discursive designs to evaluate novel technologies (focus groups and workshop designs).

\section{$\underline{\text { Multi-strategy research }}$}

Although there are some classic examples of mixed-method designs (Roethlisberger et al. 1939; Jahoda et al. 1933/1982), multi-strategy research did not become popular until the 1980s (Kelle 2007). Only recently has the growing number of mixed-method research activities led to a more systematic methodological reflection of the various aspects regarding the integration of rather different approaches (see e.g. Tashakkori/Teddlie 2003; Kelle 2007). The main argument for combining qualitative and quantitative methods on the project level is to maximise the validity of results by 'multiple triangulation', as first mentioned by Denzin (1970), who argued that 'sociological reality is such that no single method, theory, or observer can ever capture all that is relevant and important' (Denzin 1970/2009, p. x). Johnson and Turner (2003) have pointed out that 'methods should be mixed in a way that has complementary strengths and non-overlapping weaknesses' (299). From a purely methodological point of view, however, it is difficult to decide which combination of methods will lead to results with high significance and validity. To better deal with this inevitable problem, Kelle (2007: 48) has proposed that mixed designs should be developed in a process that matches objects of research with theoretical considerations and methods that are appropriate to the research questions. 
Table 2 Main characteristics of empirical research and data used

\begin{tabular}{|c|c|c|c|c|}
\hline Article & Research strategy & Design & Method & Empirical data \\
\hline I & $\begin{array}{l}\text { Qualitative and } \\
\text { quantitative }\end{array}$ & $\begin{array}{l}\text { Case study } \\
\text { Survey research }\end{array}$ & $\begin{array}{l}\text { Face-to-face } \\
\text { interview } \\
\text { Semi-structured } \\
\text { interview }\end{array}$ & $\begin{array}{l}238 \text { solar collector self-builders } \\
8 \text { interviews with group organisers and } \\
\text { self-building movement activists }\end{array}$ \\
\hline II & $\begin{array}{l}\text { Qualitative and } \\
\text { quantitative }\end{array}$ & $\begin{array}{l}\text { Case study } \\
\text { Survey research }\end{array}$ & $\begin{array}{l}\text { Mail survey } \\
\text { Semi-structured } \\
\text { interview }\end{array}$ & $\begin{array}{l}400 \text { occupants of environmentally } \\
\text { advanced buildings } \\
144 \text { households using ventilation } \\
\text { systems in low-energy buildings } \\
25 \text { interviews with component } \\
\text { producers, architects, planners and } \\
\text { users }\end{array}$ \\
\hline III & Qualitative & $\begin{array}{l}\text { Exploratory } \\
\text { assessment }\end{array}$ & $\begin{array}{l}\text { Focus group } \\
\text { discussion }\end{array}$ & 2 focus groups with 6 participants each \\
\hline IV & Qualitative & Case study & $\begin{array}{l}\text { Semi-structured } \\
\text { interview } \\
\text { Desk research }\end{array}$ & $\begin{array}{l}18 \text { interviews with self-builders, } \\
\text { producers, architects, planners } \\
\text { Partly based on interviews also used in } \\
\text { Article II }\end{array}$ \\
\hline $\mathrm{V}$ & (mainly) Quantitative & $\begin{array}{l}\text { Evaluation } \\
\text { research } \\
\text { Technology } \\
\text { Assessment }\end{array}$ & $\begin{array}{l}\text { Face-to-face } \\
\text { interview } \\
\text { Expert interview (in } \\
\text { preparatory phase) } \\
\text { Life-cycle } \\
\text { assessment (LCA) }\end{array}$ & $\begin{array}{l}42 \text { interviews with car-free housing } \\
\text { tenants } \\
46 \text { interviews in reference settlement } \\
3 \text { interviews with experts }\end{array}$ \\
\hline VI & $\begin{array}{l}\text { Qualitative and } \\
\text { quantitative }\end{array}$ & $\begin{array}{l}\text { Constructive } \\
\text { Technology } \\
\text { Assessment (CTA) }\end{array}$ & $\begin{array}{l}\text { Mail survey } \\
\text { Focus group } \\
\text { discussion } \\
\text { Various other } \\
\text { methods (natural- } \\
\text { science) }\end{array}$ & $\begin{array}{l}58 \text { residents of } 3 \text { regions } \\
40 \text { participants, split into } 3 \text { groups }\end{array}$ \\
\hline VII & $\begin{array}{l}\text { Qualitative and } \\
\text { quantitative }\end{array}$ & Case study & $\begin{array}{l}\text { Semi-structured } \\
\text { interviews } \\
\text { Mail survey }\end{array}$ & $\begin{array}{l}19 \text { interviews with network managers, } \\
\text { energy consultancies, company } \\
\text { representatives, etc. } \\
32 \text { questionnaires from network } \\
\text { customers }\end{array}$ \\
\hline VIII & Qualitative & Case study & $\begin{array}{l}\text { Semi-structured } \\
\text { interview } \\
\text { Desk research }\end{array}$ & $\begin{array}{l}7 \text { interviews with architects, builders, } \\
\text { networks managers, company } \\
\text { representatives, etc. }\end{array}$ \\
\hline IX & $\begin{array}{l}\text { Qualitative and } \\
\text { quantitative }\end{array}$ & Participatory TA & $\begin{array}{l}\text { Group discussion } \\
\text { Silent negotiation } \\
\text { Mail survey }\end{array}$ & $\begin{array}{l}12+36 \text { laypeople } \\
12 \text { experts } \\
20 \text { participants (follow-up survey) }\end{array}$ \\
\hline $\mathrm{X}$ & $\begin{array}{l}\text { Qualitative (research } \\
\text { and workshops) }\end{array}$ & $\begin{array}{l}\text { CTA } \\
\text { Case study }\end{array}$ & $\begin{array}{l}\text { Semi-structured } \\
\text { expert interview } \\
\text { Workshop series }\end{array}$ & $\begin{array}{l}10 \text { interviews with fuel cell experts } \\
3 \text { consecutive meetings with } 16 \\
\text { participants in total }\end{array}$ \\
\hline
\end{tabular}

Most of the empirical research presented here is based on mixed-method designs. The main reason for choosing mixed designs can be found in the specific context of my research, which often has focused on the relation between users and novel technology. I 
frequently complement this strategy by choosing a technology-focused case study design and qualitative social research methods as the main quantitative methods in the approach. In some projects, quantitative surveys were used to collect representative data from technology users, asking about their attitudes, knowledge, experiences, expectations and requirements. A good example of this kind of research is the mail survey reported on in Article II, where a nationwide sample of about 400 users of environmentally advanced buildings provided a valuable overview of this specific market segment. In cases like this, user surveys have indeed generated novel information on technical facts or sociodemographic descriptions of user groups and have enriched our understanding of the different 'social constructions' or interpretations users make of a given type of technology. However, the nature of this kind of quantitative research is mainly descriptive. The aim is more to get an overview of various user groups and to eventually find some empirical relationships (e.g. between attitudes of individual users and structural contexts) than to test well-established theories.

In the field of science and technology studies, with its strong tradition of qualitative case study-oriented research, the use of mixed-method designs could certainly help to integrate agency- and structure-oriented approaches. Representative surveys are definitely able to shed light on structural conditions for action. We can use them to learn more about the distribution of necessary resources as well as the restrictions of individual social actors. Survey research, for instance, shows that users differ widely in their ability to actively appropriate novel technology; such research makes it possible to quantify differences and thereby give a more accurate picture. In STS research, statistical data may be used in an exploratory fashion as well as to verify theoretical assumptions, but either way it must be seen as a fruitful methodological extension.

\section{$\underline{\text { Research in multi- and interdisciplinary contexts }}$}

Another important aspect of my research is work in multi- and interdisciplinary contexts. Not surprisingly, the most prominent examples of this work can be found at the intersection between technology assessment and sustainability research, since multi- and interdisciplinary or even transdisciplinary project teams are of particular importance in both fields. From the beginning, TA has been conceptualised as an interdisciplinary research activity, one which attempts to identify and assess as many relevant impacts of novel technology ('comprehensiveness') as possible by drawing upon a broad scientific knowledge base. Multi- and interdisciplinary forms of cooperation became popular within the field of sustainability research because of their reputed ability to tackle complexity and solve social relevant problems more effectively than single-discipline approaches (Pohl/Hirsch-Hadorn 2006).

A typical example of a multidisciplinary project is the work on sustainable wastewater technology (Article VI). In the first part of the project, a broad 'pool of sustainable options' was selected and specified in technical and economic terms. In the second part, each option was evaluated using economic, social, hygienic, environmental and legal criteria. The selected evaluation foci were represented by at least one expert on the project team. Each discipline provided assessments of the selected technological options. It was not 
necessary in this case to blend the involved disciplines and research practices to come up with an integrated approach, since the main aim of the project was to discuss criteria for the selection of appropriate solutions by planners and policy makers, rather than to find the most sustainable wastewater solution. According to our findings, it would be all but impossible to find such a solution anyway, since the outcome of assessments is highly dependent on specific local conditions.

The case study presented in Article V, however, was developed as an interdisciplinary project from the beginning. This study aimed to bring together competences from different disciplines (industrial ecology, economy, sociology) in order to develop new methods for calculating the environmental impact of households, explain diverging impacts through sociological findings, and finally test this method in practice. The challenging part of this project was to collect data sufficient in quantity and quality to allow for a representative analysis of different settlements. Evaluations of Household Environmental Impact (HEI) are usually based on consumer expenditure surveys (CES) collected by statistical offices. These detailed surveys require that respondents record all their expenditures over a 2-4 week period in a diary and then submit to an extensive interview about larger purchases. Such a survey is hence connected with substantial effort and costs. Recordings from a single household are only representative of that household for the period recorded, so that artificial households must be assembled out of different surveys covering an entire year.

We therefore developed an approach to estimate a household's environmental impact based on data obtained through a one-hour interview with the household and access to utility bills. This approach and the corresponding survey make systematic use of existing data, such as building characteristics and data about the building, and use the Austrian CES to estimate the composition of residual expenditures not covered in the survey. The survey systematically covers appliance ownership, ownership of cars and real estate, energy use and transportation behaviour, as well as a number of sociological items and sociodemographic information.

The empirical part of the project was conducted as a case-control study of the car-free model housing project in Vienna. Results show that measured per household, per capita or per Euro spent, the car-free housing settlement had lower $\mathrm{CO}_{2}$ emissions than the reference settlement. Both settlements surveyed showed lower emissions than the Austrian average. We found higher levels of environmental concern in the car-free settlement, and a high level of active information-seeking regarding environmental issues. Residents also have much more personal contact and there is more social cohesion in the car-free settlement. All these factors seem to contribute to reduced car use, but only social cohesion and number of social contacts significantly correlate with reduced per-capita $\mathrm{CO}_{2}$ emissions.

Although a large part of my research has been done in cross-disciplinary contexts, most other papers in this collection highlight findings based on social research strategies. However, it is important to mention that this research was influenced and encouraged by a variety of different disciplines and theoretical traditions. Doing sociological research on innovation and technology in cooperation with technology experts or within technological research programmes provides various opportunities for cross-disciplinary exchange and 
learning - sometimes as an explicit goal, sometimes as an implicit side effect. But strategies for inter- or transdisciplinary research are by no means an end in themselves. As our examples described above have shown, it is very important to design cross-disciplinary projects in line with the aims and questions of the intended research.

Discursive designs and methods to evaluate novel technologies

Another specific feature of my empirical work is the use of discursive designs in both research and assessment studies. Methods used include workshops with stakeholders, various forms of group work (brainstorming, moderated designs, SWOT analysis, silent negotiation, etc.) and focus group discussions. In the following I will highlight my experiences with focus groups as a discursive method to critically assess novel technologies by potential users. This is the field to which my work has probably contributed the most in methodological terms.

Results from focus group discussions are presented in Article III and Article VI. I have also been involved in a number of similar projects in recent years which used focus groups to discuss and evaluate novel technology (Suschek-Berger/Ornetzeder 2006; Rohracher/Ornetzeder 2002; Prehal/Poppe 2003).

The focus group discussion is a well-established research method with a long tradition in the social sciences. Originally developed by sociologist Robert K. Merton to study the impact of modern mass media (Merton/Kendall 1946), focus groups are now frequently used for market research and usability tests (e.g. software development), and in the course of the increasing popularity of qualitative methods in the last three decades have also become popular for scientific research in general (e.g. media and health studies, evaluation research).

In the classic focus group setting, five to ten participants discuss a specific topic under controlled conditions. The participants all have a common experience (e.g. provided by a short presentation or a short movie), which serves as the starting point for the discussion. The discussion has to be facilitated by a skilled moderator in a way that everyone participates and the group stays on track. The moderator is responsible for maintaining a pleasant atmosphere during the conversation, for channelling incipient conflicts and for ensuring that as many participants as possible become involved, while he or she maintains a neutral attitude on the topics at hand. A typical group session lasts about two hours and covers a range of questions formulated in advance and limited (focused) to a small number. As a rule, the discussion is recorded; it is then transcribed and analysed using methods of content analysis.

Focus groups became popular in the TA field at the end of the 1990s (Dürrenberger et al. 1999; Hörning et al. 1999; Jaeger et al. 1999). In this discipline, the focus group setting was conceptualised as a method between research and participation, as a way to support technology-learning processes by providing a kind of interface between laypeople and technology producers and/or policy makers. Focus groups seem to be an appropriate method for TA because '[ $t$ ]he open response format of the focus group provides an opportunity to obtain large and rich amounts of data in the respondents' own words' (Stewart et al. 2007, p. 42). With focus groups we are able to 'obtain deeper levels of 
meaning, make important connections, and identify subtle nuances in expression and meaning' (ibid.). The reason for this, as Morgan and Krueger have rightly pointed out, is that 'by comparing and contrasting', participants 'become more explicit about their own views' (Morgan/Krueger 1993, p. 17). Participants listen to others' verbalised experiences, which stimulate memories, ideas, and experiences in participants (Lindlof/Taylor 2002). This synergistic effect of group discussions helps to reveal a broad spectrum of meanings and different forms of lay expertise. Moreover, focus groups are rather close to the realworld conditions in which individuals collectively make sense of a phenomenon.

I used focus groups in my research in order to critically discuss novel technologies in five different projects over the last ten years, covering the following topics: concepts for sustainable buildings (Article III), pre-fabricated passive houses (Prehal/Poppe 2003), smart home technology (Rohracher/Ornetzeder 2002), ecological refurbishments (Suschek-Berger/Ornetzeder 2006), and sustainable wastewater technology (Article VI). As the overall aim in all of these cases was to support technology learning, actual or potential technology users attended the discussions. We worked with both natural and selected groupings, with homogeneous and heterogeneous compositions. Typically the discussions started with a short oral presentation, except in one case where a short film (introduction to smart home technology) was also shown. The presentations were made by team members or by external technology experts. Since outcomes that would be relevant for further research (and development) were a foremost priority, main questions commonly dealt with opinions and values, past experiences, interests and possible meanings provoked by the technologies presented. In most cases, we used a short written questionnaire that would help us collect socio-demographic data and also give us standardised answers to some of the most important questions raised in the discussions.

Our examples indicate that the focus group method is well-suited to producing brief assessments of technological concepts. Typical outcome qualities cover (i) perceived positive and negative aspects of the presented technology, (ii) descriptions of possible (social) impacts, (iii) rankings of different options (based on questionnaires), (iv) statements regarding desirable qualities, and (v) reports of users' personal experiences. Moreover, this kind of focus group research allowed us to compare different user groups (e.g. ecologically aware versus technophile users) and was helpful in validating and explicating already existing findings (e.g. acceptance problems of separation and compost toilets).

Focus groups turned out to be effective in producing comprehensive user representations even when the number of groups remained small. In combination with written questionnaires, we were able to produce comprehensive overviews. Demands on participants turned out to be extremely low (e.g. no special skills or knowledge required, no advance preparation necessary) in comparison to workshop designs. However, we have also learned that there are some clear limitations to this method. The quantity and complexity of given information is limited (e.g. in comparison to workshop designs). If technological alternatives are presented, the number of these should be no more than three. As a matter of fact, the presentation of technological options is a key factor for success. Information must be easy to understand and give balanced coverage to possible positive and negative aspects. Problems may arise when presentations are made by external technology experts. 
Even if these experts have received instructions in advance from focus group organisers, their presentations are very likely to be biased. Focus groups in such cases must face not only problems with observer dependency but also with an effect that we have termed 'presenter dependency'. 


\section{Conclusion and Outlook}

The papers in this collection revolve around the question of how mission-oriented technological innovation can be theoretically framed and empirically analysed. Technological innovation was considered one of the crucial elements of the broadly accepted political goal to bring sustainability into society. Although technology certainly plays a major role in this process, it is also clear that technology alone will never solve the problems societies are facing today. Accordingly STS scholars have framed the relation between technology and society as a process of co-evolution, a process in which society constructs technology and in turn is affected by novel technology - in this view, technology enables but also constrains human action.

Focusing on a number of case studies on innovation processes in the field of sustainable technology, we can draw the following conclusions:

Users are a valuable source for technological innovation: Users are able to provide usecontext-specific expertise that could be highly relevant for defining and solving problems, eventually leading to technological innovations and new market opportunities. Early users can trigger completely new technologies and designs; they can find and test new applications of a product, inspire incremental technical changes and discover new methods of use. Based on these findings, I have argued that mission-oriented technological innovation has to be built on user-orientated forms of expertise (which may include the discovery of additional functionalities and new and attractive symbolic aspects), since sustainable technology often has to compete with mature solutions that are already firmly entrenched.

User innovation depends on multiple preconditions: While users are already represented in technological development in one way or another, under specific conditions users are able to shape technologies in a more fundamental and far-reaching manner. However, the extent to which users get involved in technological innovation depends on a number of preconditions: on technical and economic characteristics of the technology itself, on the stage of development in terms of technology and market dissemination, on specific motivations of users and on available socio-cultural resources. In addition, the case studies on self-building have shown that group effects - interaction and mutual completion in heterogeneous groups - stimulate and enable technological problem-solving to a great extent.

Innovation-relevant knowledge takes effect through processes of social learning: Users may come up with innovation-relevant knowledge independently, but it is of decisive importance to disseminate, evaluate and incorporate this knowledge into ongoing developments through processes of social learning. On the one hand, social learning requires appropriate learning environments. On the other, social learning mediates between the different groups involved: between users and producers, producers and politics, research and production. Using the example of the successful innovation and diffusion processes of passive houses in Austria, we have argued that intermediary actors play a crucial role in facilitating social learning. In this case, the intermediary actors were 
able to adjust to changing requirements over time, and the intermediary activities have since been successfully extended to an increasing number of different organisations as various small experiments outgrow their local niches.

Since the research in this collection is based on a large number of empirical studies, I have presented and discussed some of the most important methodological aspects of my work in this outline paper. In my capacity as a professional social science researcher, I have made my most notable contributions in the areas of the development of mixed-method research designs, the use of focus group discussions in participatory TA projects, and the advancement of multi- and interdisciplinary research strategies.

My technology assessment projects, as presented in Chapter 3 of this outline paper, to a large extent draw on research on user innovation and social learning. In TA, however, the emphasis on social learning comes from a rather different angle. Here, the research itself acts as a facilitator for mutual exchange, reflexive learning and participatory assessment. In the examples presented, research was mainly used to identify appropriate loci for intervention or to map existing actor constellations in the selected fields. We showed through our project that the applied 'loci of alignment' variants of CTA are indeed able to create new arenas for reflection and mutual learning. However, the achieved results remain somewhat case-specific, and therefore have been useful mostly for participants and direct addressees. Compared to long-term practical learning in real use contexts, the outcomes of one-time TA interventions have been more in the realm of problem-defining than of problem-solving. Even so, for this latter purpose the use of focus group discussions to involve a larger number of lay people in such processes has shown promising results.

Based on my own experiences, I have also discussed the problem of technology bias, which has not gained much attention so far but is easily inherent in 'loci of alignment' variants of CTA. The point is that in CTA we start from a particular technology area and attempt to contribute to technology learning and momentum-building around the technology, rather than working from social needs, application contexts and problem situations, or exploring a broader range of technological and organisational solutions. This 'dilemma of alignment', as we have called it, should certainly be more closely considered during the planning for any 'loci of alignment' CTA project in the future.

The primary focus of my personal research agenda for the upcoming years will be on energy issues. Not only is energy supply vital to modern societies, but the way we produce and consume energy is also one of the key issues when we talk about sustainability. Limited fossil fuel resources and the threat of global warming have led to a broad consensus that the current energy system must undergo a radical change in the near future. According to the EU's Strategic Energy Technology Plan (SET-Plan), the reinvention and radical transformation of the energy system is the critical challenge of the $21^{\text {st }}$ century (Commission of the European Communities 2009). Given the changes and developments already in progress, the wide-ranging political support the energy topic has gained in the last years, and the additional financial resources that have been announced, it would not be 
unrealistic to expect the projected transformations in the energy sector to begin in the present decade.

The orientation towards the energy system as a whole, rather than in part, offers a multitude of interesting starting points for STS research. Rohracher $(2008$, p. 147) recently proposed that we understand energy systems as

socio-technical configurations where technologies, institutional arrangements (e.g. regulation, norms), social practices and actor constellations (such as user-producer relations and interactions, intermediary organisations, public authorities) mutually depend on each other, and are embedded into broader contexts of cultural values, socio-economic trends (globalisation, individualisation, etc.).

To deal with radical transitions of the energy system is thus to be aware of complex processes of social learning involving a multitude of actors and levels, such as energy providers, policy actors or consumers, social networks and broader societal contexts. Such research also implies a focus on the required technological innovation at the niche level, as well as on the larger socio-technical contexts of those developments.

The ongoing project E-Trans $2050^{5}$ is a good example of research that deals with longterm transformations of the Austrian energy system. This project builds on interactive engagement with stakeholders to discuss and further develop energy future scenarios. The normative scenarios will be complemented with backcasting processes that investigate the necessary paths and strategies needed to reach a desirable future. The chosen approach should provide new insights because of the participation by experts from selected 'key action fields' (e.g. the role of civil society) and extend the range of possibilities to be considered for further action and strategy development. The aim is to find and investigate some of the central issues within the key action fields, issues which have the potential to foster system innovation, to influence the energy system to a wide extent and are relevant to the transition path (Ornetzeder et al. 2010).

Another stream of my future research focuses on the interface between energy endusers and the electricity system. In Europe, there are ambitious efforts to add the functionality of communication networks to the electricity grid. The aim of these efforts is to better utilise technologies and solutions in order to improve grid operation, intelligently control generation, increase the efficiency of the whole system, and enable new energy services (ERGEG 2009). A future 'smart grid' of this type would certainly create a number of new requirements and opportunities for energy end-users. Utilities based on a new ICT infrastructure would be able to offer new value-added services and to integrate end-users as active participants in the electricity system. In the near future, I will be involved in two research projects focusing on some of these new opportunities: demand side management and smart metering.

\footnotetext{
5 The project E-Trans 2050 is funded by the Austrian Climate and Energy Funds and carried out under the programme 'New Energy 2020'. The project team is made up of colleagues from the Inter-University Research Centre for Technology, Work and Culture (lead), the Austrian Institute of Technology, the Institute of Forest and Environmental Policy at the University of Freiburg and the Institute of Technology Assessment at the Austrian Academy of Sciences.
} 
The aim of the research on smart metering is to evaluate and critically reflect on the results of a one-year field test covering 280 households in Austria. ${ }^{6}$ The test period is expected to start in May 2010. Each household in the study will have a smart meter installed along with an in-home display featuring a number of functions to monitor energy consumption. Effects on energy consumption will be evaluated in a before-and-after design using qualitative and quantitative research methods. Building on previous STS research on energy consumption, we will bear in mind that 'private energy consumption is part of a complex network' (Aune 2007) and that the focus of the research is not a single consumer but the whole household, considered as a dynamic social system.

In a second project, ${ }^{7}$ an interdisciplinary team will explore promising options for consumption-oriented energy management solutions. Here, the focus of analysis will be on consumer-side energy management and its potential to contribute to overall energy efficiency of future smart grids in the best possible way. The project will include an assessment of the environmental impacts of load management, which will not only cover the marginal utility of the last produced energy unit preserved by way of load rescheduling, but will also compare this benefit with the ecological rucksack of the technical infrastructure needed to actually implement load management. Different types of consumers will evaluate the most ecologically promising scenarios in focus group discussions. The comprehensive and interdisciplinary approach of this project aims to contribute to the further development of smart power grids in Austria.

Other research topics of personal interest cover 'renewable energy regions', 'zeroemission houses', and 'citizens as energy suppliers'. Moreover, the above-mentioned scenario project E-Trans 2050 suggests follow-up research to focus either on trade-offs among different forms of renewable energy sources and between energy production and other forms of land use (e.g. food production); or on path-dependencies of the incumbent energy system and their resistance to change.

The transformation of the energy system to sustainability obviously leads to a broad and diversified research agenda. In my own forthcoming research, I will follow a few of the most interesting paths as I contribute to the 'engaged programme' of STS by, as Bijker (1995, pp. 289-290) puts it, 'combining empirical work with theoretical reflection to strengthen the links between academic STS studies and politically relevant action'.

\footnotetext{
6 This research is funded by the Austrian Climate and Energy Funds and carried out under the programme 'New Energy 2020'. The project-lead: Wegener Center for Climate and Global Change, University of Graz 7 Title: 'Demand Response for Austrian Smart Grids'. Project team: Institute of Computer Technology at the Technical University Vienna (lead), KERP Center of Excellence Electronics \& Environment, and the Institute of Technology Assessment at the Austrian Academy of Sciences.
} 


\section{Annotated list of articles}

Article I Ornetzeder, M., 2001, Old Technology and Social Innovations. Inside the Austrian Success Story on Solar Water Heaters, in: Technology Analysis \& Strategic Management, Volume 13, Number 1, March, pp. 269-278

This article represents independent personal scientific work. It is based on a project collaboration with Roger Hackstock, Kurt Könighofer and Wilhelm Schramm, in which I was responsible for the entire empirical research process. I also personally carried out most of the interviews with experts and users.

Article II Rohracher, H., Ornetzeder, M., 2002, Contextualising Green Buildings: Improving Social Learning Processes between Users and Producers, in: Built Environment, Volume 28, Number 1, pp. 73-84

This article is based on two different but related research projects; I led one project, and Harald Rohracher led the other. The article builds equally on findings from both projects.

Article III Ornetzeder, M., 2003, Sustainable Technology and User Participation. Assessing Ecological Housing Concepts by Focus Group Discussions, in: Mira, Ricardo Garcia/Jose Manuel Sabucedo Cameselle/Jose Romay Martinez (eds.): Culture, Environmental Action and Sustainability, pp. 145-160

This article represents independent personal scientific work.

Article IV Ornetzeder, M., Rohracher, H., 2006, User-led Innovations and Participation Processes: Lessons from Sustainable Energy Technologies, in: Energy Policy, Volume 34, Issue 2, January, pp. 138-150

This article features three case studies; I prepared two of these.

Article V Ornetzeder, M., Hertwich, E., Hubacek, K., Korytarova, K., Haas, W., 2007, The Environmental Effect of Car-free Housing: A Case in Vienna, in: Ecological Economics 65, pp. 516-530

This article reports on results from a project using a novel interdisciplinary approach. I was responsible for the empirical part of the project, data analysis and interpretation, and the final report. In the second part of the project I was the responsible project leader at IIASA.

Article VI Starkl, M., Ornetzeder, M., Binner, E., Holubar, P., Pollak, M., Dorninger, M., Mascher, F., Fuerhacker, M., Haberl, R., 2007, An Integrated Assessment of Options for Rural Wastewater Management in Austria, in: Water Science E Technology, Vol 56 No 5 pp. 105-113

This article is based on a multidisciplinary project on sustainable wastewater technologies. In the project I was mainly responsible for doing research on social acceptance issues. I carried out a standardised survey and organised three focus group discussions. In addition to that, I supervised a quantitative survey on users of separation toilets. As the article gives an overview of the project findings, my contribution is subsidiary.

Article VII Ornetzeder, M., Suschek-Berger, J., 2008, Innovation Networks in the Refurbishment Sector of Austria: Promising Approaches Waiting for Market Success, in: International fournal of Innovation and Sustainable Development, Vol. 3, Nos. 3/4, pp. 285-300

I am the main author of this article. It builds on a project that was initiated and led by me. I also did all the qualitative empirical work. However, my colleague Suschek-Berger contributed valuable quantitative research.

Article Ornetzeder, M., Rohracher, H., 2009, Passive Houses in Austria: The Role of Intermediary VIII Organisations for the Successful Transformation of a Socio-technical System, in: Broussous, C., Jover, C., (eds.), Act! Innovate! Deliver! Reducing energy demand sustainably, Conference proceedings, eceee 2009 Summer Study, Stockholm, pp. 1531-1541

This article combines empirical research with theoretical reflection. I was mainly responsible for the case study presented. 
Article IX Ornetzeder, M., Bechtold, U., Nentwich, M., 2009, Participatory Assessment of Sustainable End-user Technology in Austria, in: Brebbia, C.A. and Mammoli, A.A., (eds.), Energy and Sustainability II, WIT press, Southampton and Boston, pp. 269-278

This article represents selected findings of and reflects on experiences with a pTA exercise. The project was led by Michael Nentwich. My colleague Ulrike Bechtold and myself did most of the work within the project and shared tasks equally. However, I was responsible for the majority of work on the paper.

Article X Schreuer, A., Ornetzeder, M., Rohracher, H., 2010, Participatory Technology Development and Assessment: In Search of a Sustainable Use of Fuel Cell Technology at the Municipal Level, in: Technology Analysis \& Strategic Management, forthcoming

This article is based on a recently finished project that I initiated and led. The article reports and reflects on one of the case studies. The work on the paper was shared equally between Anna Schreuer and me. Harald Rohracher contributed valuable ideas and acted as a kind of internal reviewer. 


\section{References}

Akrich, M., 1995, User representations: practices, methods and sociology, in: Rip, A., Misa, T. J. and Schot, J. (Eds): Managing technology in society: the approach of constructive technology assessment, London: Cassell, 167-184.

Allerbeck, K. and Hoag, W., 1989, Utopia is around the Corner: Computerdiffusion in den USA als soziale Bewegung, Zeitschrift für Soziologie 18(1), 35-53.

Arrow, K. J., 1962, The economic implications of learning by doing, Review of Economic Studies 29, 155-173.

Aune, M., 2007, Energy comes home, Energy Policy 35(11), 5457-5465.

Bechmann, G., Decker, M., Fiedeler, U. and Krings, B.-J., 2007, Technology assessment in a complex world, International fournal of Foresight and Innovation Policy 3(1), 6-27.

Beck, U., 1992, Risk society: towards a new modernity, London: Sage Publications Ltd.

Bijker, W. E., 1992, The social construction of fluorescent lighting, or how an artifact was invented in its diffusion stage, in: Bijker, W. E. and Law, J. (Eds): Shaping technology/building society: studies in sociotechnical change, Cambridge/London: The MIT Press, 75-102.

Bijker, W. E., 1993, Do not despair: there is life after constructivism, Science Technology Human Values 18(1), 113-138.

Bijker, W. E., 1995, Of bicycles, bakelites, and bulbs: towards a theory of sociotechnical change, Massachusetts: MIT Press.

Bijker, W. E. and Law, J. (Eds), 1992, Shaping technology/building society: studies in sociotechnical change, Massachusetts: MIT Press.

BMLFUW (Ed.), 2002, Die Österreichische Strategie zur Nachhaltigen Entwicklung, Wien: Bundesministerium für Land- und Forstwirtschaft, Umwelt und Wasserwirtschaft

Brand, R., 2005, Synchronizing science and technology with human behaviour, London: Earthscan.

Brekke, O. A. and Eriksen, E. O., 1999, Technology assessment in a deliberative perspective, in: Schomberg, R. v. (Ed.): Democratising technology: theory and practice of deliberative technology policy, Hengelo, Netherlands: International Centre for Human and Public Affairs, 93-115.

Bröchler, S. and Simonis, G., 1998, Konturen des Konzepts einer innovationsorientierten Technikfolgenabschätzung und Technikgestaltung, TA-Datenbank-Nachrichten 7(1), 31-40.

BUND/Misereor (Ed.), 1996, Zukunftsfähiges Deutschland - Ein Beitrag zu einer global nachhaltigen Entwicklung, Basel: Birkhäuser Verlag.

Callon, M., 1986, The sociology of an actor-network: the case of the electric vehicle, in: Callon, M., Law, J. and Rip, A. (Eds): Mapping the Dynamics of Science and Technology: Sociology of Science in the Real World, London: Macmillan, 19-34.

Clark, W. G., 2007, Sustainability Science: A room of its own, Proceedings of the National Academy of Sciences 104(6), 1737-1738.

Coleman, J., 1988, Social capital in the creation of human capital, American fournal of Sociology 94 (Supplement), 95-120. 
Collingridge, D., 1980, The social control of technology, London: Frances Pinter (Publishers) Ltd.

Collins, H. M. and Evans, R., 2002, The third wave of science studies: studies of expertise and experience, Social Studies of Science 32(2), 235-296.

Commission of the European Communities, 2009, Investing in the Development of Low Carbon Technologies (SET-Plan).

Decker, M. and Ladikas, M. (Eds), 2004, Bridges between science, society and policy: technology assessment - methods and impacts, Vol. Wissenschaftsethik und Technikfolgenbeurteilung 22, Berlin/Heidelberg/New York: Springer.

Denzin, N. K., 1970/2009, The research act: a theoretical introduction to sociological methods, New Brunswick, NJ: Aldine Transaction.

Dolata, U. and Werle, R., 2007, "Bringing technology back in": Technik als Einflussfaktor sozioökonomischen und institutionellen Wandels, in: Dolata, U. and Werle, R. (Eds): Gesellschaft und die Macht der Technik: Soziökonomischer und institutioneller Wandel durch Technisierung, Frankfurt/Main: Campus Verlag, 15-43.

Dosi, G., 1982, Technological paradigms and technological trajectories: a suggested interpretation of the determinants and directions of technical change, Research Policy 11, 147-162.

Douthwaite, B., Keatinge, J. D. H. and Park, J. R., 2001, Why promising technologies fail: the neglected role of user innovation during adoption, Research Policy 30, 819-836.

Dürrenberger, G., Kastenholz, H. and Behringer, J., 1999, Integrated assessment focus groups: bridging the gap between science and policy?, Science and Public Policy 26(5), 341-349.

Eames, M., McDowall, W., Hodson, M. and Marvin, S., 2006, Negotiating contested visions and place-specific expectations of the hydrogen economy, Technology Analysis ES Strategic Management 18(3/4), 361-374.

Edge, D., 1995, Reinventing the wheel, in: Jasanoff, S., Markle, G. E., Petersen, J. C. and Pinch, T. (Eds): Handbook of Science and Technology Studies, London: Sage Publications, $3-23$.

Enquete-Kommission (Ed.), 1998, Konzept Nachhaltigkeit: Vom Leitbild zur Umsetzung, Abschlußbericht der Enquete-Kommission "Schutz des Menschen und der Umwelt - Ziele und Rahmenbedingungen einer nachhaltig zukunftsverträglichen Entwicklung" des 13. Deutschen Bundestages, Bonn.

Fleck, J., 1988, Innofusion or diffusation? the nature of technological development in robotics, 1988, Edinburgh: University of Edinburgh.

Fleischer, T. and Grunwald, A., 2002, Technikgestaltung für mehr Nachhaltigkeit Anforderungen an die Technikfolgenabschätzung, in: Grunwald, A. (Ed.): Technikgestaltung für eine nachhaltige Entwicklung: Von der Konzeption zur Umsetzung, Berlin: edition sigma, 95-146.

Fonk, G., 1994, Een constructieve rol van de consument in technologie-ontwikkeling (A Constructive Contribution of Consumers in Technology Development), Twente Twente.

Franke, N. and Shah, S., 2003, How communities support innovative activities: an exploration of assitance and sharing aming end-users, Research Policy 32, 157-178.

Fuchs, G. and Wassermann, S., 2008, Picking a winner? innovation in photovoltaics and the political creation of niche markets, STI Studies 4(2), 93-113. 
Fürst, D., 2001, Die Bedeutung von Netzwerken in modernen Gesellschaften, in: Kanning, H. E. (Ed.): Netzwerke und Nachhaltigkeit: Vernetzte Probleme - vernetztes Denken - vernetzte Lösungen. Schriftenreihe des Doktoranden-Netzwerkes Nachhaltiges Wirtschaften e.V., Band 6, Hannover.

Geels, F. W., 2004, From sectoral systems of innovation to socio-technical systems: insights about dynamics and change from sociology and institutional theory, Research Policy 33(6-7), 897-920.

Geels, F. W. and Schot, J., 2007, Typology of sociotechnical transition pathways, Research Policy 36(3), 399-417.

Genus, A. and Coles, A.-M., 2005, On constructive technology assessment and limitations on public participation in technology assessment, Technology Anlysis \& Strategic Management 17(4), 433-443.

Gilfillan, S. C., 1935, The sociology of invention, Chicago: Follet.

Grin, J. and Graaf, H. v. d., 1996, Technology assessment as learning, Science, Technology $\mathcal{E}^{\circ}$ Human Values 21(1), 72-99.

Grunwald, A. (Ed.), 1999, Rationale Technikfolgenbeurteilung, Berlin/Heidelberg: SpringerVerlag.

Grunwald, A., 2002a, Technikfolgenabschätzung: Eine Einführung, Berlin: edition sigma.

Grunwald, A. (Ed.), 2002b, Technikgestaltung für eine nachhaltige Entwicklung: Von der Konzeption zur Umsetzung; in series: Global zukunftsfähige Entwicklung - Perspektiven für Deutschland, Berlin: edition sigma.

Hackett, E. J., Amsterdamska, O., Lynch, M. and Wajcman, J., 2008a, Introduction, in: Hackett, E. J., Amsterdamska, O., Lynch, M. and Wajcman, J. (Eds): The handbook of science and technology studies, Cambridge, Mass.: MIT Press; Published in cooperation with the Society for the Social Studies of Science, 1-7.

Hackett, E. J., Amsterdamska, O., Lynch, M. and Wajcman, J. (Eds), 2008b, The handbook of science and technology studies, 3rd edition, Cambridge, Mass.: MIT Press.

Heiskanen, E., 2005, Taming the golem: an experiment in participatory and constructive technology assessment, Science Studies 18(1), 52-74.

Hellmer, F., Friese, C., Kollros, H. and Krumbein, W., 1999, Mythos Netzwerke: Regionale Innovationsprozesse zwischen Kontinuität und Wandel, Berlin: edition sigma.

Hodson, M. and Marvin, S., 2009, Cities mediating technological transitions: understanding visions, intermediation and consequences, Technology Analysis $\mathcal{G}^{\circ}$ Strategic Management 21(4), 515 - 534.

Hofstätter, P. R., 1986, Gruppendynamik, Hamburg: Rowohlt.

Hoogma, R., Kemp, R., Schot, J., Truffer, B. and Banister, D., 2002, Experimenting for sustainable transport: the approach of strategic niche management, Vol. Transport, Development and Sustainability, London: Spon Press.

Hoogma, R. and Schot, J., 2001, How innovative are users? a critique of learning-by-doing and -using, in: Coombs, R., Green, K., Richards, A. and Walsh, V. (Eds): Technology and the Market. Demand, Users and Innovation, Cheltenham/Northampton: Edward Elgar Publishing Inc., 216-232. 
Hörning, G., Keck, G. and Lattewitz, F. (Eds), 1999, Die gesellschaftliche Bewertung zukunftsweisender Energieszenarien: Fokusgruppen, Stuttgart: Akademie für Technikfolgenabschätzung in Baden-Württemberg.

Hughes, T. P., 1986, The seamless web: technology, science, etcetera, etcetera, Social Studies of Science 16, 281-292.

Jaeger, C. C., Schüle, R. and Kasemir, B., 1999, Focus groups in integrated assessment: a micro-cosmos for reflexive modernization, Innovation 12(2), 195-219.

Jahoda, M., Lazarsfeld, P. F. and Zeisel, H., 1933/1982, Die Arbeitslosen von Marienthal: Ein soziographischer Versuch mit einem Anhang zur Geschichte der Soziographie, Frankfurt: Suhrkamp.

Jasanoff, S., 2004, States of knowledge: the co-production of science and social order; in series: International library of sociology, London/New York: Routledge.

Johnson, B. and Turner, L. A., 2003, Data collection strategies in mixed methods research, in: Tashakkori, A. and Teddlie, C. (Eds): Handbook of mixed methods in social \& behavioral research, Thousand Oaks, Calif.: SAGE Publications, 297-320.

Jorgensen, U. and Karnøe, P., 1995, The Danisch wind-turbine story: technical solutions to political visions?, in: Rip, A., Misa, T. J. and Schot, J. (Eds): Managing technology in society: the approach of constructive technology assessment, London: Cassell, 57-82.

Joss, S. and Bellucci, S. (Eds), 2002, Participatory technology assessment: european perspectives, London: Centre for the Study of Democracy.

Kaluza, B., Blecker, T. and Bischof, C., 1999, Networks - a cooperative approach to environmental management, commissioned by: Universität Klagenfurt, I. f. W., Klagenfurt.

Karnøe, P., 1996, The social process of competence building, International fournal of Technology Management 11(7/8), 770-789.

Kasemir, B., Jäger, J., Jaeger, C. C. and Gardner, M. T. (Eds), 2003, Public participation in sustainability science: a handbook, Cambridge, UK; New York, NY: Cambridge University Press.

Kelle, U., 2007, Die Integration qualitativer und quantitativer Methoden in der empirischen Sozialforschung: Theoretische Grundlagen und methodologische Konzepte, 1. Aufl. edition, Wiesbaden: VS Verlag für Sozialwissenschaften.

Kemp, R., Rip, A. and Schot, J., 2000, Constructing transition paths through the management of niches, in: Garud, R. and Karnøe, P. (Eds): Path Creation and Dependence, Hillsdale, NJ: Lawrence Erlbaum Associates.

Kemp, R., Schot, J. and Hoogma, R., 1998, Regime Shifts to Sustainability Through Processes of Niche Formation: The Approach of Strategic Niche Management, Technology Analysis \& Strategic Management 10(2), 175-195.

Klein, H. K. and Kleinmann, D. L., 2002, The social construction of technology: structural considerations, Science, Technology Ë Human Values 27(1), 28-51.

Kline, R. and Pinch, T., 1996, Users as agents of technological change: the social construction of the automobile in the rural United States, Technology and Culture 37(4), 763-795.

Klunder, G., 2005, Sustainable solutions for Dutch housing: reducing the environmental impacts of new and existing houses, Delft: Delft University Press. 
Kopfmüller, J., Brandl, V., Jörissen, J., Paetau, M., Banse, G., Coenen, R. and Grunwald, A., 2001, Nachhaltige Entwicklung integrativ betrachtet: Konstitutive Elemente, Regeln, Indikatoren; in series: Global zukunftsfähige Entwicklung - Perspektiven für Deutschland, Berlin: edition sigma.

Kowohl, U. and Krohn, W., 1995, Innovationsnetzwerke: Ein Modell der Technikgenese, in: Halfmann, J., Bechmann, G. and Rammert, W. (Eds): Technik und Gesellschaft, Frankfurt/Main: Campus, 77-105.

Küppers, G., 2002, Complexity, self-organisation and innovation networks: a new theoretical approach, in: Pyka, A. and Küppers, G. (Eds): Innovation networks: theory and practice, Cheltenham: Edward Elgar, 22-52.

Küppers, G. and Pyka, A., 2002, The self-organisation of innovation networks: introductory remarks, in: Pyka, A. and Küppers, G. (Eds): Innovation networks: theory and practice, Cheltenham: Edward Elgar, 3-21.

Law, J., 1987, Technology and heterogeneous engineering: the case of Portuguese expansion, in: Bijker, W. E., Hughes, T. P. and Pinch, T. (Eds): The Social Construction of Technological Systems, Cambridge, MA: The MIT Press, 111-134.

Lindlof, T. R. and Taylor, B. C., 2002, Qualitative communication research methods, 2nd edition, Thousand Oaks, Calif.: SAGE Publications.

Loibl, M. C., 2006, Integrating perspectives in the practice of transdisciplinary research, in: Voß, J.-P., Bauknecht, D. and Kemp, R. (Eds): Reflexive governance for sustainable development, Cheltenham, Glos, UK ; Northampton, MA: Edward Elgar, 294-309.

Lundvall, B.-A., 1988, Innovation as an interactive process: from user-producer interaction to the national system of innovation, in: Dosi, G., Freeman, C., Nelson, R., Silverberg, G. and Soete, L. (Eds): Technical Change and Economic Theory, London/New York: Pinter, 349-369.

Mackay, H. and Gillespie, G., 1992, Extending the social shaping of technology approach: ideology and appropriation, Social Studies of Science 22, 685-716.

MacKenzie, D. and Wajcman, J., 1999, Introductory essay: the social shaping of technology, in: MacKenzie, D. and Wajcman, J. (Eds): The Social Shaping of Technology, 2nd edition, Milton Keynes: Open University Press, 3-27.

MacKenzie, D. A. and Wajcman, J., 1985, The Social shaping of technology: how the refrigerator got its hum, Milton Keynes; Philadelphia: Open University Press.

Majer, H., 2005, Institutionelle Innovationen für Nachhaltigkeit, Wien.

Mayntz, R., Scharpf, F. W. and Max-Planck-Institut für Gesellschaftsforschung., 1995, Gesellschaftliche Selbstregelung und politische Steuerung; in series: Schriften des MaxPlanck-Instituts für Gesellschaftsforschung, Köln, Frankfurt/New York: Campus.

Merton, R. K. and Kendall, P. L., 1946, The focused interview, American Fournal of Sociology (51), 541-557.

Metz, B. and Intergovernmental Panel on Climate Change. Working Group III., 2007, Climate change 2007: mitigation of climate change: contribution of Working Group III to the fourth assessment report of the Intergovernmental Panel on Climate Change, Cambridge/New York: Cambridge University Press.

Meyer, R., 1999, Eine kurze Geschichte der TA-Konzepte, TAB Brief 17, 4-11. 
Minsch, J., undated, Gedanken zu einer politischen Kultur der Nachhaltigkeit [Accessed on: 15. April 2005] <http://www.iff.ac.at/socec/backdoor/sose05-ring-sozoek/03 Minsch_04.pdf>.

Morgan, D. L. and Krueger, R. A., 1993, When to use focus groups and why?, in: Morgan, D. L. (Ed.): Successful focus groups: advancing the state of the art, Newbury Park, Calif.: Sage Publications, 3-19.

Moss, T., 2005, New intermediary services and the transformation of urban water supply and wastewater disposal systems in Europe, commissioned by: 6, E. C. S.: Institute for Regional Development and Structural Planning (IRS).

National Research Council (Ed.), 1999, Our common journey: a transition toward sustainability, Washington, D.C.: National Academy Press.

Nelson, R. R. and Winter, S. G., 1977, In search of useful theory of innovation, Research Policy 6, 36-76.

Nentwich, M., Bechtold, U. and Ornetzeder, M., 2008, Future Search \& Assessment "Energie und EndberbraucherInnen", Wien: Institut für Technikfolgen-Abschätzung.

Nentwich, M., Bogner, A., Peissl, W., Sotoudeh, M. and Torgersen, H., 2006, Techpol 2.0: Awareness - Partizipation - Legitimität: Vorschläge zur partizipativen Gestaltung der österreichischen Technologiepolitik, Wien: Institut für Technikfolgen-Abschätzung.

Nowotny, H., 2009, The passions and the interests: what has STS to say about climate change?, University of Copenhagen, Workshop on "Science Studies Meet Climate Change", Copenhagen.

Nowotny, H., Scott, P. and Gibbons, M., 2001, Rethinking Science, Cambridge: Polity Press.

Ogburn, W. F., 1969, Kultur und sozialer Wandel: Ausgewählte Schriften, Neuwied: Luchterhand.

Ornetzeder, M., 2000, Die Solaranlage: Soziale Genese einer zukunftsfähigen Technik, in series: Koinon: Sozialwissenschaftliche interdisziplinäre Studien, Vol. 4, Frankfurt am Main: Peter Lang.

Ornetzeder, M. and Rohracher, H., 2005, Social learning, innovation and sustainable technology, in: Filho, W. L. (Ed.): Handbook of Sustainability Research, Frankfurt/Main: Peter Lang Verlag, 147-175.

Ornetzeder, M. and Rohracher, H., 2007, User-led innovations and social learning processes as basis for sustainable energy policy: lessons from the Austrian solar case, International Conference to Questions of the Sustainable Development of Regions, Prague.

Ornetzeder, M., Wächter, P., Rohracher, H., Schreuer, A., Weber, M., Kubeczko, K., Paier, M., Knoflacher, M. and Späth, P., 2010, Beyond energy scenarios: exploring critical socio-economic issues in the transformation of the energy system, Sussex Energy Group Conference, Brighton, UK.

Oudshoorn, N. and Pinch, T. (Eds), 2003, How users matter: the co-construction of users and technologies, Cambridge, MA: The MIT Press.

Oudshoorn, N. and Pinch, T., 2008, User-technology relationships: some recent developments, in: Hackett, E. J., Amsterdamska, O., Lynch, M. and Wajcman, J. (Eds): The handbook of science and technology studies, Cambridge, Mass.: MIT Press, 541565.

Perry, N., 1993, Scientific communication, innovation networks and organization structures, Fournal of Management Studies 30(6), 957-974. 
Pinch, T. J. and Bijker, W. E., 1987, The social construction of facts and artifacts: or how the sociology of science and the sociology of technology might benefit each other, in: Bijker, W. E., Hughes, T. P. and Pinch, T. (Eds): The Social Construction of Technological Systems, Cambridge, MA: The MIT Press, 17-50.

Podolny, J. M. and Page, K. L., 1998, Network forms of organization, Annu. Rev. Sociol. 24, 57-76.

Pohl, G. and Hirsch-Hadorn, G., 2006, Gestaltungsprinzipien für transdisziplinäre Forschung, München: oekom.

Pohl, G., Wülser, G. and Hirsch Hadorn, G., 2010, Transdisziplinäre Nachhaltigkeitsforschung: Kompromittiert die Orientierung an der gesellschaftlichen Leitidee den Anspruch als Forschungsform?, in: Bogner, A., Kastenhofer, K. and Torgersen, H. (Eds): Inter- und Transdisziplinarität im Wandel? Neue Perspektiven auf problemorientierte Forschung und Politikberatung, Baden-Baden: Nomos, 123-143.

Porter, M. E., 1980, Competitive strategy: techniques for analyzing industries and competitors, New York: Free Press.

Prehal, A. and Poppe, H., 2003, SIP - Siedlungsmodelle in Passivhausqualität, in series: Berichte aus Energie- und Umweltforschung, No. 01/2003, Wien: BMVIT.

Putnam, R., 1993, Making democracy work, Princeton: Princeton University Press.

Quist, J. and Vergragt, P., 2006, Past and future of backcasting: the shift to stakeholder participation and a proposal for a methodological framework, Futures 38(9), 10271045.

Rammert, W., 1995, Regeln der technikgenetischen Methode. Die soziale Konstruktion der Technik und ihre evolutionäre Dynamik, in: Halfmann, J., Bechmann, G. and Rammert, W. (Eds): Technik und Gesellschaft, Jahrbuch 8: Theoriebausteine der Techniksoziologie, Frankfurt/New York: Campus, 13-30.

Rammert, W., 2000, Wer ist der Motor der technischen Entwicklung heute?, in: Rammert, W. (Ed.): Technik aus soziologischer Perspektive 2. Kultur - Innovationen - Virtualität, Wiesbaden: Westdeutscher Verlag GmbH, 174-189.

Renn, O., Deuschle, J., Jäger, A. and Weimer-Jehle, W. (Eds), 2007, Leitbild Nachhaltigkeit: Eine normativ-funktionale Konzeption und ihre Umsetzung, 1. Aufl. edition, Wiesbaden: VS Verlag für Sozialwissenschaften.

Rip, A. and Kemp, R., 1998, Technological change, in: Rayner, S. and Malone, E. L. (Eds): Human choice and climate change: resources and technology, Columbus, Ohio: Batelle Press, 327-399.

Rip, A., Misa, T. J. and Schot, J., 1995a, Constructive technology assessment: a new paradigm for managing technology in society, in: Rip, A., Misa, T. J. and Schot, J. (Eds): Managing technology in society: the approach of constructive technology assessment, London/New York: Pinter, 1-12.

Rip, A., Misa, T. J. and Schot, J., 1995b, Epilogue, in: Rip, A., Misa, T. J. and Schot, J. (Eds): Managing technology in society: the approach of constructive technology assess, London/New York: Pinter, 347-354.

Rip, A. and Schot, J., 2002, Identifying loci for influencing the dynamics of technological development, in: Sørensen, K. H. and Williams, R. (Eds): Shaping technology, guiding policy: concepts, spaces \& tools, Cheltenham/Northampton: Edward Elgar. 
Roelofsen, A., Broerse, J. E. W., de Cock Buning, T. and Bunders, J. F. G., 2008, Exploring the future of ecological genomics: integrating CTA with vision assessment, Technological Forecasting and Social Change 75(3), 334-355.

Roethlisberger, F. J., Dickson, W. J., Wright, H. A., Pforzheimer, C. H. and Western Electric Company., 1939, Management and the worker: an account of a research program conducted by the Western Electric Company, Hawthorne Works, Chicago, Cambridge, Mass.: Harvard University Press.

Rogers, E. M., 1995, Diffusion of innovations, 4th edition, New York: The Free Press.

Rohracher, H., 2006, The Mutual Shaping of Design and Use: Innovations for Sustainable Buildings as a Process of Social Learning; in series: Technik- und Wissenschaftsforschung; 52, München: Profil.

Rohracher, H., 2008, Energy systems in transition: contributions from social sciences, International Fournal of Environmental Technology and Management 9(2/3), 144-161.

Rohracher, H. and Ornetzeder, M., 2002, Intelligent and green? Nutzerzentrierte Szenarien für den Einsatz von IEKK-Technologien in Wohngebäuden unter dem Gesichtspunkt ihrer Umwelt- und Sozialverträglichkeit; in series: Berichte aus Energie- und Umweltforschung, Wien: BMVIT.

Rosenberg, N., 1982, Inside the black box: technology and economics, Cambridge: Cambridge University Press.

Russell, S. and Williams, R., 2002, Social shaping of technology: frameworks, findings and implications for policy with glossary of social shaping concepts, in: Sørensen, K. H. and Williams, R. (Eds): Shaping Technology, Guiding Policy: Concepts, Spaces and Tools, Cheltenham: Edward Elgar, 37-131.

Schmidt, J. F. K., 1997, Der Personal Computer (1974-1985). Achitektonische Innovation und vertikale Desintegration, in: Weyer, J., Kirchner, U., Riedl, L. and Schmidt, J. F. K. (Eds): Technik, die Gesellschaft schafft: Soziale Netzwerke als Ort der Technikgenese, Berlin: edition sigma, 147-226.

Schmutzer, M., 1994, Ingenium und Individuum: Eine sozialwissenschaftliche Theorie von Wissenschaft und Technik, Wien: Springer-Verlag.

Schneidewind, U., Feindt, P. H., Meister, H.-P., Minsch, J., Schulz, T. and Tscheulin, J., 1997, Institutionelle Reformen für eine Politik der Nachhaltigkeit: Vom Was zum Wie in der Nachhaltigkeitsdebatte, GAIA 6(3), 182-196.

Schot, J., 2001, Towards new forms of participatory technology development, Technology Analysis $\mathcal{E}$ Strategic Management 13(1), 39-52.

Schot, J., Hoogma, R. and Elzen, B., 1994, Strategies for shifting technological systems: The case of the automobile system, 26(10), 1060-1076.

Schot, J. and Rip, A., 1996, The past and future of Constructive Technology Assessment, Technological Forecasting and Social Change 54, 251-268.

Schwartz Cowan, R., 1987, The consumption junction: a proposal for research strategies in the sociology of technology, in: Bijker, W. E., Hughes, T. P. and Pinch, T. (Eds): The Social Construction of Technological Systems, Cambridge, MA: The MIT Press, 261280.

Shove, E., 2001, Users' role in creating technologies and expectations of comfort, cleanliness and convenience: some notes, International Summer Academy on Technology Studies: User Involvement in Technological Innovation, July 8 - 13, 2001. 
Sismondo, S., 2008a, An introduction to science and technology studies, 2nd edition, Malden, MA: Wiley-Blackwell.

Sismondo, S., 2008b, Science and technology studies and an engaged program, in: Hackett, E. J. and Society for Social Studies of Science. (Eds): The handbook of science and technology studies, 3rd edition, Cambridge, Mass.: MIT Press; Published in cooperation with the Society for the Social Studies of Science, 13-32.

Slaughter, S. E., 1993, Builders and sources of construction innovation, fournal of Construction Engineering and Management 119(3), 532-549.

Sørensen, K. H., 1996, Learning technology, constructing culture: socio-technical change as social learning, Dragvoll: Norwegian University of Science and Technology, Centre for Technology and Society.

Sørensen, K. H., 2002, Social shaping on the move? on the policy relevance of the social shaping of technology perspective, in: Sorensen, K. H. and Williams, R. (Eds): Shaping technology, guiding policy: concepts, spaces $\mathbb{E}$ tools, Cheltenham/Northampton: Edward Elgar, 19-36.

Sørensen, K. H. and Williams, R. (Eds), 2002, Shaping technology, guiding policy: concepts, spaces $\mathcal{E}$ tools, Cheltenham/Northampton: Edward Elgar.

Spiegel-Rösing, I. and de Solla Price, D. (Eds), 1977, Science, technology and society: a crossdisciplinary perspective, London: Sage.

Steinmüller, K., Tacke, K. and Tschiedel, R., 1999, Innovationsorientierte Technikfolgenabschätzung, in: Bröchler, S., Simonis, G. and Sundermann, K. (Eds): Handbuch Technikfolgenabschätzung, Berlin: Rainer Bohn Verlag, 129-144.

Stewart, D. W., Shamdasani, P. N. and Rook, D. W., 2007, Focus groups: theory and practice; in series: Applied social research methods series, 2nd edition, Thousand Oaks: SAGE Publications.

Stewart, J. and Williams, R., 2005, The wrong trousers? beyond the design fallacy: social learning and the user, in: Rohracher, H. (Ed.): User involvement in innovation processes: strategies and limitations from a socio-technical perspective, München/Wien: Profil Verlag, 39-71.

Suschek-Berger, J. and Ornetzeder, M., 2006, Kooperative Sanierung: Modelle zur Einbeziehung von BewohnerInnen bei nachhaltigen Gebäudesanierungen, commissioned by: BMVIT, No. 54/2006, Wien: BMVIT.

Tashakkori, A. and Teddlie, C. (Eds), 2003, Handbook of mixed methods in social Ë behavioral research, Thousand Oaks, Calif.: SAGE Publications.

Taylor, P., 1995, Building on construction: an exploration of heterogeneous constructionism, using an analogy from psychology and a sketch from socioeconomic modelling, Perspectives on Science 3(1), 66-98.

Toffler, A., 1980, The third wave, New York: Bentam Books.

Truffer, B., 2003, User Led innovation processes: the development of professional carsharing by environmentally concerned citizen, Innovation - The European Fournal of Social Science Research 16(2), 139-154.

Tuomi, I., 2002, Networks of innovation: change and meaning in the age of the Internet, Oxford, [England]; New York: Oxford University Press. 
Tushman, M. L. and Rosenkopf, L., 1992, Organizational determinants of technological change: toward a sociology of technological evolution, Research in Organizational Behavior 14, 311-347.

United Nations, 1993, Report of the United Nations conference on environment and development, volume I, resolutions adopted by the conference, New York.

Van Boxsel, J., 1994, Constructive technology assessment: a new approach for technology assessment developed in the Netherlands and its significance for technology policy, in: Aichholzer, G. and Schienstock, G. (Eds): Technology Policy: Toward an Integration of Social and Ecological Concerns, Berlin/New York: Walter de Gruyter, 181-203.

Van Den Bosch, S. J. M., Brezet, J. C. and Vergragt, P. J., 2005, How to kick off system innovation: a Rotterdam case study of the transition to a fuel cell transport system, Fournal of Cleaner Production 13(10-11), 1027-1035.

Van den Ende, J., Mulder, K., Knot, M., Moors, E. and Vergragt, P., 1998, Traditional and modern technology assessment: toward a toolkit, Technological Forecasting and Social Change 58(1-2), 5-21.

Van Merkerk, R., 2007, Intervening in emerging nanotechnologies: a CTA of lab-on-a-chip technology, Utrecht: Koninklijk Nederlands Aardrijkskundig Genootschap, Copernicus Institute for Sustainable Development and Innovation.

Van Merkerk, R. O. and Smits, R. E. H. M., 2008, Tailoring CTA for emerging technologies, Technological Forecasting and Social Change 75(3), 312-333.

Vergragt, P. J. and Brown, H. S., 2004, Policies for social learning: "bounded sociotechnical experiments", Conference on human dimensions of global environmental change "Greening of politics- interlinkages and policy integration, Berlin.

Vergragt, P. J. and Brown, H. S., 2007, Sustainable mobility: from technological innovation to societal learning, Fournal of Cleaner Production 15(11-12), 1104-1115.

Vestby, G. M., 1996, Technologies of autonomy? parenthood in contemporary 'modern times', in: Lie, M. and Sørensen, K. H. (Eds): Making Technology our Own? Domesticating Technology into Everyday Life, Oslo: Scandinavian University Press, 65-90.

Von Hippel, E., 1986, Lead users: a source of novel product concepts, Management Science 32(7), 791-805.

Von Hippel, E., 1988, The sources of innovation, Oxford/New York: Oxford University Press.

Von Hippel, E., 1998, Economics of product development by users: the impact of "sticky" local information, Management Science 44(5), 629-644.

Von Hippel, E., 2001, Innovation by user communities: learning from open-source software, Sloan Management Review 42(4), 82-86.

Voß, J.-P. and Kemp, R., 2006, Sustainability and reflexive governance: introduction, in: Voss, J.-P., Bauknecht, D. and Kemp, R. (Eds): Reflexive Governance for Sustainable Development, Cheltenham, Glos, UK; Northampton, MA: Edward Elgar, 3-27.

Weber, K. M., 2005, Innovation diffusion, social networks and the self-organisation of large socio-technical systems, in: Rohracher, H. (Ed.): User Involvement in Innovation Processes. Strategies and Limitations from a Socio-Technical Perspective, München-Wien: Profil Verlag, 208-243.

Weber, M. and Hoogma, R., 1998, Beyond national and technological styles of innovation diffusion: a dynamic perspective on cases from the energy and transport sectors, Technology Analysis \& Strategic Management 10(4), 545-566. 
Weber, M., Hoogma, R., Lane, B. and Schot, J., 1999, Experimenting with sustainable transport innovations: a workbook for Strategic Niche Management, Seville/Enschede: IPTS.

Wenger, E., 1998, Communities of practice: learning, meaning and identity, Cambridge: Cambridge University Press.

Werle, R., 1998, An institutional approach to technology, Science Studies (1), 3-18.

Weyer, J., 1997, Konturen einer netzwerktheoretischen Techniksoziologie, in: Weyer, J., Kirchner, U., Riedl, L. and Schmidt, J. F. K. (Eds): Technik, die Gesellschaft schaff, Berlin: Edition Sigma, 23-52.

Weyer, J., 2006, Path-making by actor networks: the case of the winged space plane, EIASM Workshop "Organizing Paths - Paths of Organizing", Berlin.

Weyer, J., Kirchner, U., Riedl, L. and Schmidt, J. F. K., 1997, Technik, die Gesellschaft schaff: Soziale Netzwerke als Ort der Technikgenese, Berlin: edition sigma.

Williams, R., 2002, Introduction, in: Sørensen, K. H. and Williams, R. (Eds): Shaping technology, guiding policy: concepts, spaces $\&$ tools, Cheltenham/Northampton: Edward Elgar, 3-18.

Williams, R. and Edge, D., 1996, The social shaping of technology, Research Policy 25, 856899.

Williams, R., Steward, J. and Slack, R., 2005, Social learning in technological innovation: experimenting with information and communication technologies, Cheltenham/Northampton: Edward Elgar.

Winner, L., 1993, Social constructivism: opening the black box and finding it empty, Science as Culture 3(16), 427-452. 
Selected Articles

Part B 


\title{
Old Technology and Social Innovations. Inside the Austrian Success Story on Solar Water Heaters
}

\author{
MICHAEL ORNETZEDER
}

ABSTRACT A central claim of sustainable development is the far-reaching use of renewable forms of energy. This article focuses on the fact that solar water heaters are much more popular in Austria than in most other European countries. The enormous success of solar heaters in the 1990s is explained by two specific social phenomena that only can be observed in Austria: first, by a self-construction movement, consisting of single do-it-yourself groups started in the early 1980s that has spread throughout Austria. A major aspect of this movement was a comprehensive diffusion strategy that made it easy for nearly everyone to get a solar water system. Second, an atypical group of adopters were responsible for the unexpected dissemination success. Most of these early adopters were households in rural regions, interested in solar heaters due to a feature that already played a central role in the very beginning of this technology-more personal comfort. The close connection between the self-construction movement and early users enabled ongoing technical improvements of the system, which were adopted by commercial producers and installation companies.

\section{Introduction}

For many years, visions and political declarations have required the intensified use of renewable sources of energy with regard to the threatening climatic changes. In most industrialized countries, this means a radical transformation of the present power supply structure. Austria has a special role, not only because of its traditionally high proportion of electricity from water power, but also due to its prominent position concerning the use of solar water heaters, as compared to other European countries. How can we explain this unusual and, according to the intention of sustainability, desirable situation? Is there a connection between the responsibility for the future of society and the development and application of solar thermal systems?

Theoretical approaches that focus on the institutional environment of technical innovations like the concept of 'visions' (Leitbilder) or technological paradigms would suggest such interpretations. ${ }^{1}$ However, scholars of diffusion theory argue that the entire diffusion process of an innovation consists of a sequence of decision-making processes that place potential adopters at the centre of interest. ${ }^{2}$ Following actor-orientated social studies of technology, a clear separation between innovation and diffusion processes is no longer fruitful. On the contrary, successful diffusion processes are dependent on ongoing technological improvements that can be essentially supported by user-feedback. ${ }^{3}$ In this context, Bijker ${ }^{4}$ stresses from a social-constructivist view that technology is continually

Michael Ornetzeder is at the Centre for Social Innovation (ZSI), Koppstraße 116/11, A-1160 Vienna, Austria. Tel: +43 14950 44254; Fax: +43 14950 44240; E-mail: ornetzeder.zsi@mail.boku.ac.at 


\section{M. Ornetzeder}

reshaped and redesigned by various social groups during its diffusion. Users of innovations are no longer only adopters but are actively shaping the technology they adopt.

The following sections will address such questions by focusing on a case study concerning the diffusion of solar water heaters in Austria. Solar technology, in Austria, is not only deemed a sustainable technical solution, but compared to other European countries, a very popular alternative source of heat.

\section{Sustainability and the Need for Solar Technology}

Sustainable development is - at least in a rhetorical sense - the international trend-setting concept for the formation of an ecologically and socially sound growth. The idea of sustainability originally comes from forestry, referring to a long-term form of husbandry. By the 1970s, this way of thinking had already emerged in the international environmental protection debate. ${ }^{5}$ In 1983, the United Nations created the World commission for Environment and Development, whose report 'Our Common Future', generally referred to as the Brundtland Report, introduced the concept of sustainable development as 'development that meets the needs of the present without compromising the ability of future generations to meet their own needs'. ${ }^{6}$ Since the Brundtland Report was published in 1987, many different social actors seized the concept of sustainability. Subsequently it was developed further and complemented by other perspectives. The participants at the United Nations Conference on Environment and Development in Rio de Janeiro in 1992 discussed the issues of environment, social justice and development, in order to find pathways to a globally sustainable future. One of the documents of this conference, the Agenda 21, is a sort of task book for the 21 st Century. In the preamble the authors declare:

However, integration of environment and development concerns and greater attention to them will lead to the fulfilment of basic needs, improved living standards for all, better protected and managed ecosystems and a safer, more prosperous future. ${ }^{7}$

In contrast to the classical environmental protection concept of the 1970s and 1980s, sustainability is perceived as an active modernization and structural change strategy that operates on a global level. Furthermore, it functions as a kind of vision for the development of societies in the 21 st century. The central idea is to combine three major targets: the protection of the environment, stabilization of economic conditions, and social justice on a national and international level. The chapters of the Agenda 21 look at what role different social sectors and actors have and should play in achieving sustainable development. In reference to the protection of the atmosphere, Agenda 21 invites governments at different levels, non-governmental organizations and the private sector to start, among other things, the following activities:

Promote the research, development, transfer and use of technology and practices for environmentally sound energy systems, including new and renewable energy systems, with particular attention to developing countries. ${ }^{8}$

Moreover, the invited social actors should initiate education and awareness-raising programmes concerning energy efficiency and environmentally sound energy systems. Therefore it is not difficult to deduce the concrete vision of an energy supply system based totally on renewable forms of energy, e.g. solar energy, biomass and wind. The aim seems to be clear; however there is much confusion over the question of which strategies will lead to success. 


\section{Invention: A Short Historical Note on Solar Water Heaters}

The invention of the solar water heater did not result from ecological reasons or concerns. Historical research points out that the solar water heater is a (surprisingly) very old technology. ${ }^{9}$ The common solar heater in use today was developed in the US at the end of the last century. The first patent for an 'Apparatus for Utilizing the Sun's Rays for Heating Water' was granted in 1891. A few years later, the new technology was available for homeowners. After a very successful local dissemination, mainly in California and Florida, solar heaters were pushed out of the market by the gas and electricity industry in the 1920s. After World War II, there were no producers of solar heaters remaining in the American market.

The emergence and commercial success of the first solar heaters in the US were mainly driven by social change, rather than by ecological concerns. More and more households were interested in time- and labour-saving innovations due to the process of industrialization. At that time, the preparation of hot water was one of the first domestic chores that was substituted by technology. Therefore, various technical options were developed at the end of the 19th century (e.g. solar, gas, electricity). The design of solar heaters was only one out of several alternative ways for the local people to replace traditional forms of co-operation in the household.

Changed standards of personal hygiene increased the need for hot water, thereby encouraging the development of mechanized hot water preparation. However, this development was a slow one: in the mid 19th century only a few upper-class households could afford the luxury of this new technology. All other households used less mechanized means (e.g. wood-burning ovens, etc.) for heating their water. However, the desire for more hot water developed as American hotels began building personal bathrooms. These hotels housed travellers and immigrants who thus became exposed, for the first time, to the comfort of a bath tub and flowing warm water.

At the same time, the American women's movement strongly advocated for the rationalization of the household. This movement asked for the efficient arrangement of household work, not only because servants were rejected to a large extent by the women's movement, but also to allow women, not just men, to participate in (political) activities outside of the house. A substantial prerequisite for the rationalization of housework was the so-called 'servant problem' of the 19th century: a term used to describe the lack of qualified personnel for household labor. This situation, at the time exclusively concerning the US, resulted from bad work conditions in households, a permanent lack of workers in the area of industry, the unrestricted supply of cheap farmland, and the incompatibility of 'feudalistic' residuals with the requirements of a modern democracy. Inventors reacted to this situation with concrete suggestions on the mechanization of labor intensive activities. Thus, the solar water heaters were not regarded as an environmentally sound technology, but rather as a response to historical events and social needs.

\section{Diff usion: Solar Water Heaters in Austria and Europe}

Thermal solar technologies are the most popular options world-wide for the direct use of solar energy. In private households flat-plate or vacuum collectors are used to convert solar power into thermal heat. Here, the produced low-temperature energy is first used for the heating of domestic hot water, then for the partial heating of dwellings. In comparison with all other conventional methods (fossil fuels, electricity, solid fuels) the use of solar energy is the most environmentally sound technical alternative at the present time. 
One German technology evaluation on solar technology commends, in particular, the peripherally installed solar water heaters regarding economic, ecological, social and legal criteria. As far as the undesirable consequences are concerned, only aesthetic aspects, waste problems at the end of the life cycle, and accident risks in connection with do-it-yourself installations are of relevance. ${ }^{10}$ Solar water heaters are appropriate to the task, error compatible, and easy to repair. Experience has proven that the average life cycle is more than 20 years - which incidentally meets the requirements of sustainable development.

In Europe, solar water heaters were not adopted until the 1973 OPEC oil embargo. From 1973 to 1978 , the development of solar technology was influenced mainly by research activities and funds from public institutions and industrial companies. These activities were all driven by the fear of an energy shortage and rising oil prices. A first slight boom for solar water heaters took place in the Austrian market from 1979 to 1981, mainly caused by the second oil crisis, increasing private demand, and the market penetration by large-scale companies. This boom came to a sudden end in the early 1980 s, due to the stabilization of the oil price, and problems with the technical reliability of installations. A phase of stagnation followed and attention on solar technology waned. However in 1987, a second boom started and it is still active. In the second half of the 1990s, more than $150000 \mathrm{~m}^{2}$ of collector surface per year were installed in Austria ${ }^{11}$.

According to a current study, Austria is in second place behind Greece in Europe regarding the diffusion of solar water heaters per capita. ${ }^{12}$ Taking into consideration the annual growth rates, Austria is in first position, with Greece, Denmark, Switzerland and Germany following thereafter. ${ }^{13}$ In the last five years, particularly, a high number of new solar heaters have been installed. By the end of 1998 more than 1.3 million $\mathrm{m}^{2}$ of flat plate collector surface had been installed in Austria. At present, approximately 100000 private households are producing hot water by means of solar heaters. ${ }^{14}$ Interestingly, this extremely successful dissemination rate is due to the fact that more than $360000 \mathrm{~m}^{2}$ collector surfaces were manufactured in privately organized do-it-yourself groups. ${ }^{15} \mathrm{In}$ other words, approximately 30000 solar heaters are equipped with self-made collectors in Austria. This responsible social initiative began in the mid 1980s at a time when the topic of solar energy was very unattractive.

\section{How Gan We Explain this Success?}

Complex processes, such as the social dynamics of the diffusion of technology, depend on many different factors that change over the years. However, only two phenomena can be observed in Austria: the self-construction movement with a comprehensive diffusion strategy, and the role of atypical innovators in rural regions. ${ }^{16}$ Both of these phenomena are of major importance for the nationwide success of solar technology.

Two skilled Styrian amateur inventors, a fruit farmer and a technical engineer, initiated the Austrian dissemination-success of solar water heaters nearly 90 years after the first patent on this technology was taken out. Together with some friends, they developed a simple self-construction method adapted to the needs and abilities of the rural population aside from the commercial market for solar heaters. The first selfconstruction group with 32 participants was established in a small village near Graz in 1983. The motives for forming this co-operative were later summarized by the initiators as follows:

Our primary aim was to build a collector that was inexpensive and easy to build for every one of us. Having become aware of the finiteness of natural resources, we 
also aimed at avoiding all material waste in constructing the collector. Other important aspects were the saving of energy, environmental protection, and community building. Everybody was expected to build their own collector in order to be sufficiently familiar with its function. ${ }^{17}$

The idea to practise do-it-yourself methods in a group was based on a local tradition. This rural part of Austria, Eastern Styria, is well-known for its wine and fruits. People of this district are used to co-operating with each other, especially during harvest season. Even in a technical world, apples of high quality have to be picked manually. Thus, once a year, all available family members, friends and neighbors work together for a short time. Thus, if one knows how to organize and motivate an informal working-group it is relatively easy to transfer this social pattern of co-operation to other purposes.

The positive experiences made by the first construction group were soon spread by word of mouth and fueled the neighboring communities' interest in utilizing this new solar technology. Before the end of 1984, the enormous demand for these heaters required the establishment of two more construction groups, each with more than 100 participants. When more requests were made from other parts of eastern Styria, some of the more active 'technicians' decided to hold a series of evening lectures in order to explain the solar system self-construction method. These lectures were usually initiated and organized by one of the people interested in building his or her own solar heater.

From 1986 onwards, the self-construction group leaders met on a monthly basis to discuss the advantages and drawbacks of different types of systems. They invited manufacturers to present their products, compared several offers and placed orders to several construction groups. Due to these bulk purchases, they were able to produce the installations at very competitive prices. During that period, the technical system, ${ }^{18}$ underwent a number of important improvements based upon practical feedback of former participants and technical skills of new group members. For instance, the piping of the absorber was no longer soldered at every bend but produced from a single piece of copper tube. For this purpose, a special tub-fitting table was developed. At the same time, the device used for soldering sheets and pipe was considerably improved. These two technical innovations brought about not only manufacturing advantages but, by making soldering spots redundant, also considerably improved the system's reliability. A further improvement was achieved with regard to the collector housing, which for anticorrosion purposes was no longer made of zinc-lined steel sheet but of high-grade steel. In 1986, the first collectors that could be directly integrated into a house roof-provided that the angle and orientation were suitable - became available. This installation method cut production costs by avoiding the need for steel housing and, in doing so it often provided an aesthetic-looking solution. The above-mentioned special tools developed into a complete 'tool kit' that was initially rented to other groups against payment of a small fee. In 1986, the Styrian self-builders were able to produce from their small base more solar collector surface area than all of the commercial suppliers in Austria put together (see Figure 1).

In order to meet the ever-increasing demand in 1987, the first solar system build-ityourself guide was produced. Training seminars were organized for construction group leaders and other interested persons who wanted to familiarize themselves with the method of solar system self-building. To improve communication, a news bulletin titled 'solar info' was established.

An important step in this process was the institutionalization of the self-construction movement. The Association for Renewable Energy (AEE) was founded in Gleisdorf in June 1988. The AEE was awarded several environmental and research prizes that brought 


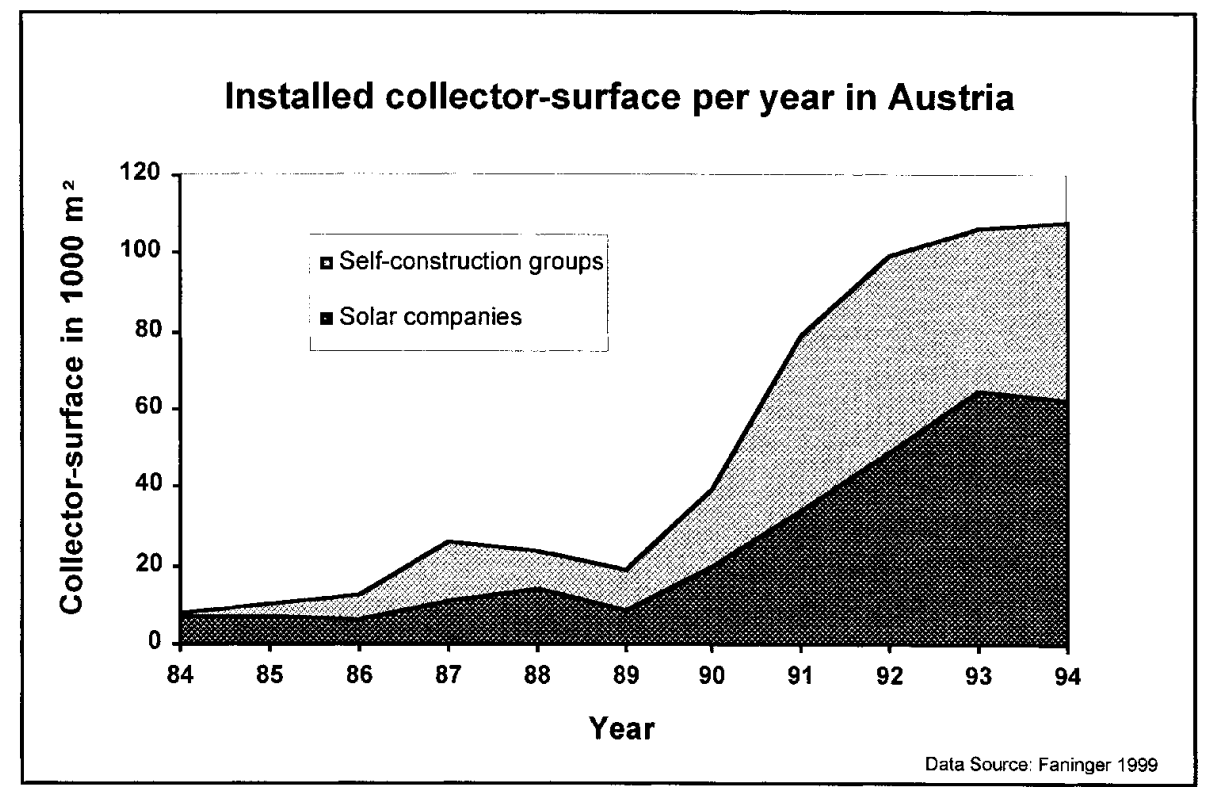

Figure 1. Market share of self-constructing groups and companies, annually installed collector-surface from 1984 to 1994.

them additional recognition. As an official representative of the solar system selfconstruction movement, the AEE was able to receive public fund support. This enabled the AEE to do their work on both a broader and more stable basis. After a few years, the AEE expanded throughout Austria by establishing regional divisions. The selfconstruction method also found followers in neighboring countries such as Switzerland, the Czech and Slovak Republics, and Slovenia.

As a result of increasing demand on solar systems for space-heating, some important improvements were made. An even more efficient type of collector was developed, and the usage of commercially available selective absorber-strips was enabled. The AEE became, meanwhile, one of the most important knowledge carriers not only in the field of thermal solar energy but also with regard of other renewable energy sources in Austria. In the year 2000, the AEE will organize a fifth international symposium on thermal and photovoltaic use of solar energy. The AEE's latest step toward professionalization was the laying of a foundation for a planning office in 1993. In spite of these recent developments, the organizational culture of the AEE still resembles that of a social movement.

\section{Diffusion Strategy}

After a number of years, the Association for Renewable Energy developed an appropriate diffusion strategy. This development resulted from the continuous demand for self-built solar systems. The diffusion strategy starts with an introductory lecture and an excursion to existing self-built solar systems. It then offers individual technical advice, guides the work within the construction-groups, and ends with a finished solar water system. This social innovation was of prime importance for the second boom on the solar market at the end of the 1980s. 
Introductory Lectures. First, independent community lectures concerning the use of solar energy and the methods of self-building are presented. The organization of these lectures occurs mainly through resident people interested in solar systems. By using local organizations to arrange the lectures, the skepticism toward the unknown is largely reduced and more interest results. These lectures bring the subject of 'renewable energy' to the people and present them with an opportunity to action themselves. For more than half of the self-builders, such a lecture is the first contact with the subject of renewable energy sources.

Visits to Installations. If people are interested in building their own solar system, they are usually invited to both join an excursion to one of the existing self-built solar systems and to talk to users about their experiences. The chance to prove the capability of this technology is a crucial point within the whole decision process. Specifically, it helps to reduce uncertainty about this technological innovation.

Sizing the System. In the course of a further meeting, a member of the AEE calculates the size of the system required, explains the connections to the existing heating and hot water system and gives advice about optimal integration. This service is necessary due to the uniqueness of every household. The calculation also helps to reduce existing uncertainties about the compatibility of solar systems.

Formation of Self-construction Groups. If participants agree to form a self-build group, a few people become responsible for its co-ordination and organization. These group leaders are provided with technical and organizational know-how at weekend seminars offered by the AEE. Every self-construction group is a financially independent organization, which decides alone where the necessary materials should be purchased. This collective purchasing maintains very low prices.

Construction Phase. The absorbers are manufactured collectively. The necessary tools such as presses, bending and soldering jigs are made available to the groups by the AEE. Teamwork also enables people with less technical experience to take part. Only after all the necessary absorbers have been produced, are they distributed among the group members.

Dissolution of the Groups. The average life of such a construction group is approximately three to four months. While the assembly and installation work is either done by the group members themselves or with the assistance of local installers, it is recommended by the AEE that groups should arrange for 'neighborhood teams' by the construction stage in order to facilitate installation by the group.

The diffusion strategy described above helps to overcome several diffusion barriers. Specifically, as a non-profit organization, the AEE brought the topic 'renewable energies' to the people, and presented at the same time a alternative approach to installation. Comprehensive information helps to reduce individually perceived 'risks'. A visit to existing sites helps motivate tentative candidates to try the new technology. The individual sizing of the systems reduces uncertainty about 'compatibility'. More than one third of the surveyed non-users said that a solar system would be difficult to install. The formation of a construction group, as well as encouraging interested people in proceeding with installations by working together, has other advantages such as collective purchasing and self-construction, enabling lower costs and providing a 'relative advantage' over previous heating systems. Through teamwork it is possible - at least theoretically - for everyone to 


\section{M. Ornetzeder}

take part. Finally, the temporal limit of the group helps to turn 'work' into an interesting variation in life. The work atmosphere within the group was spontaneously described by most of the persons surveyed as 'excellent, very good, friendly, helpful or as fun'. ${ }^{19}$

\section{Atypical Innovators}

'Atypical' innovators were primarily responsible for the start of the second boom on the solar market. According to diffusion theory, ${ }^{20}$ persons who adopt an innovation in a very early stage of the diffusion process are called innovators. They are characterized as being younger, having higher income and education, greater social mobility, and as adventurous. ${ }^{21}$ Only some of these theoretical attributes applied to the solar innovators in Austria around 1990. Therefore these solar adopters can be characterized as atypical innovators. $^{22}$

The interviewed adopters with an average age of approximately 40 years were in fact younger than the average population. More than half of them had completed a middlelevel education, e.g. a master college. The income of the adopter-households was not higher than normal. In relation to the members of the households, the income of adopters was even lower. Around 1990, solar water heaters were installed mainly in larger households, with an average size of more than four persons. (An average Austrian household only consists of 2.5 persons, and this number is decreasing.)

The most remarkable characteristic of the adopters was the extraordinary proportion of farmers and part-time farmers, nearly $50 \%$ in Styria and Lower Austria, and $31 \%$ in Upper Austria. There are several reasons for this atypical group of adopters. On farms there is normally a higher demand for warm water - a private and an operational one. Farmhouses are usually big enough, so there is no problem with the installation of a solar system. Beyond this, most of these houses were equipped with old heating technology. In summer, people had to heat these systems everyday in order to receive hot water. A solar system therefore means a lot of 'added comfort' to these people. In Styria, as well as in Lower Austria, 'added comfort' was in fact the most important motivation to adopt a solar system (see Figure 2). The individual perceived advantage of more personal comfort was mainly stimulated by the thought of replacing obsolete heating equipment. In other words, old technology was a major precondition for the successful dissemination of solar heaters in these rural regions.

\section{Conclusion}

Political support, ambitious marketing programmes, or competitive prizes were not major reasons for the success of solar heaters in the 1990s. Instead, a 'social innovation' in the form of do-it-yourself programmes within organized groups was mainly responsible. These construction-groups spread out over Austria and eventually found themselves as the innovators of a social movement. Solar water heaters had found social carriers, who were interested in this technology and supported the diffusion process on an honorary basis. Most of the rural households adopted solar heaters due to a feature that already played a central role in the very beginning of this technology-more personal comfort. The non-polluting characteristic of solar energy use was at best an additional benefit at the beginning of the second solar boom at the end of the 1980s.

A central idea of diffusion theory, the perceived 'relative advantage', helps one to understand the success of solar water heaters. An innovation spreads, if it is perceived as superior to the product it replaces. The individual advantages of solar heaters (laborsaving, personal comfort) were first seen in the emergence of the technology in the US 


\section{Motivations for adopting a solar water heater}

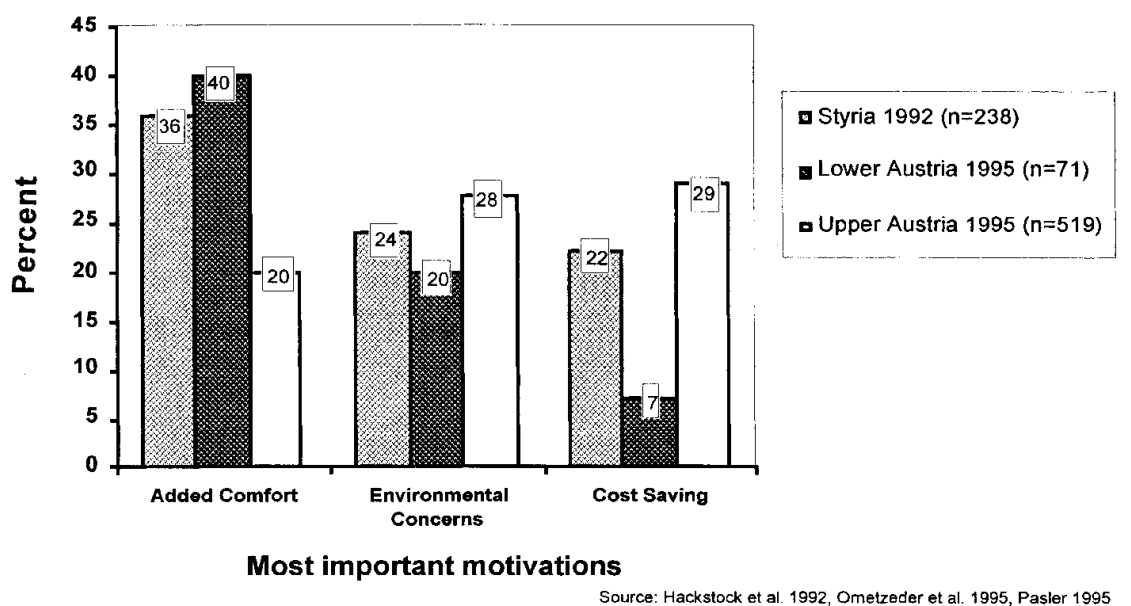

Figure 2. Motivations for adopting a solar system, comparison between the provinces Lower Austria, Upper Austria, and Styria.

as well as during the spread in Austria - an aspect of major importance. But the perception of a technical feature such as a relative advantage depends also on variable conditions. In the Austrian case, the new solar technology profited substantially from old heating systems in rural households.

The spreading of innovation usually leads to important technical optimizations, which raises again the attractiveness of the innovation compared to already existing solutions. In this respect, the self-construction movement could be seen as a large decentralized 'development division' for solar heating systems, in which over many years a great number of practice-relevant technical improvements were compiled and realized. A great number of users all over Austria were and still are in contact with the AEE. Within this network of qualified users, positive and negative experiences with the technology are communicated. Users are very close to the technology and some of them are directly involved in the improvement of the system. Many of these improvements have been adopted by commercial producers and installation companies (e.g. a special glass cover sealing, using parts of available glasshouse systems; solar systems for space-heating), which currently operate as very professional and successful enterprises. In Austria, commercial solar systems are of good quality and prices are much lower than 10 years ago.

Contrary to misgivings of solar companies, the success of the self-construction movement had positive effects on their sales as well. The further development of the solar market had an increasing dynamic by a 'self-enforcing process'. A growing number of solar collectors made it easier for potential adopters to visit existing devices. More information about this new technology was spread. It was more likely to have a friend or acquaintance who already had a solar heating system. In recent years solar companies were extremely successful in Austria, partly because of this precondition.

Even if technical alternatives cannot initially prevail on the market against established means, there are other possibilities apart from the traditional policy instruments (taxes, 


\section{M. Ornetzeder}

subsidies, regulations) to support technical innovations. In this concrete case it was a social innovation, which had been essentially based on local traditions and the commitment of interested persons. The case study also shows that new technology can be successful in niches, which seems rather unusual at first sight. But such local niches provide an opportunity for technological testing and improvement.

Socio-political events, such as the so-called oil shock in 1973, or global development concepts, such as sustainability, are capable of questioning common practices and stimulating changes in new directions. Thus, potentially new technical options appear on the agenda as well. Socially accepted visions - such as the concept of sustainability - can play a supporting role. Technology producing actors are able to refer to the vision and claim additional support for their activities.

Whether the modification of social processes towards a sustainable development can succeed, depends largely on whether the partial aims of the vision can be linked with already successful strategies. Sustainable development, as is defined for instance in the Agenda 21, offers only a few prospects for relative personal advantages. It concerns rather the 'well-being' of future generations. The example of solar technology shows however, that above all, there are subjectively-felt relative advantages which lead to success. If sustainable technology is to be successful, it has to meet not only ecological criteria, but satisfy, above all, other present social needs. It is important to note, however, that these social needs change. Sustainable technology can therefore be co-designed by modification of the user's requirements.

\section{Acknowledgements}

I would like to thank Chris Prell and Harald Rohracher for their helpful comments. Significant parts of the research work underlying this article have been carried out during two projects sponsored by the Austrian Ministry of Science and Research. Thanks also go to my colleagues Roger Hackstock, Otmar Kastner, and Klaus Hubacek.

\section{Notes and References}

1. See, for example, M. Dierkes, U. Hoffmann \& L. Marz, Leitbild und Technik. Zur Entstehung und Steuerung technischer Innovationen (Berlin, Sigma, 1992) and G. Dosi, 'Technological Paradigms and Technological Trajectories. A Suggested Interpretation of the Determinants and Directions of Technical Change', Research Policy, 11, 1982, pp. 147-162.

2. E.M. Rogers, Diffusion of Innovations (New York, Free Press, 1983).

3. B.A. Lundvall (Ed.), National Systems of Innovation. Towards a Theory of Innovation and Interactive Learning (London, Pinter, 1992).

4. W.E. Bijker, Of Bicycles, Bakelites, and Bulbs. Toward a Theory of Sociotechnical Change (Cambridge, MIT Press 1995), pp. 199-267.

5. See R. Kreibich (Ed.), Nachhaltige Entwicklung. Leitbild für die Zukunft von Wirtschaft und Gesellschaft (Weinheim/Basel, Beltz Verlag, 1996).

6. V. Hauff (Ed.), Unsere gemeinsame Zukunft. Der Brundtland-Bericht der Weltkommission für Umwelt und Entwicklung (Greven, Eggenkamp, 1987), p. 46.

7. Bundesumweltministerium (Ed.), Konferenz der Vereinten Nationen fr Umwelt und Entwicklung im Juni 1992 in Rio de Faneiro, Agenda 21 (Bonn, Bundesumweltministerium, 1997), p. 9.

8. Ibid., ch. 9, 12d.

9. M. Ornetzeder, Die Solaranlage. Soziale Genese einer zukunftsfähigen Technik (Frankfurt-am-Main, Peter Lang, 2000).

10. See E. Jochem, Technikfolgen-Abschätzung am Beispiel der Solarenergienutzung (Frankfurt-am-Main, Peter Lang, 1988). 
11. K. Hubacek, R. Hackstock, O. Kastner \& M. Ornetzeder, 'Diffusion of Solar Water Heaters in Austria', in: C. Fohler-Norek \& R. Paulesich (Eds), WU Umwelt Reader. Umwelt und Wirtschaft an der Wirtschaftsuniversität Wien (Wien, Verlag Österreich, 1997), pp. 149-172.

12. R. Hackstock, K. Hubacek, O. Kastner \& M. Ornetzeder, 'Bestimmende Faktoren der Solaranlagenverbreitung im internationalen Vergleich', Final report for the Ministry of Science and Research, Vienna, 1995, p. 183.

13. G. Stryi-Hipp, 'Solarwärmenutzung in Europa', Erneuerbare Energie, 4, 1998, pp. 4-9.

14. G. Faninger, Solarmarkt in Österreich 1998, Brochure in co-operation with Bundesverband Solar Wirtschaftskammer Österreich (Vienna, 1999), p. 19.

15. Ibid., p. 18.

16. Chapter 5 is mainly based on the results of two research projects, R. Hackstock, K. Könighofer, M. Ornetzeder \& W. Schramm, 'Übertragbarkeit der Solarkollektor-Selbsttbautechnologie', Final Report for the Ministry of Science and Research, Vienna, 1992; and Hackstock et al., op. cit., Ref. 12.

17. Some years later the two innovators reviewed their activities. R. Hödl \& R. Plesch, 'Fünf Jahre Solaranlagenbau - Eine Erfolgsbilanz', Energie Info, 1, 1988, p. 8.

18. This type of solar collector built according to the assembly method is probably the most commonly used in Austria.

19. Hubacek et al., op. cit., Ref. 11, p. 164

20. Rogers, op. cit., Ref. 2

21. H. Gatignon \& T.S. Robertson, 'A Propositional Inventory for New Diffusion Research', fournal of Consumer Research, 11, 1985, p. 861.

22. These results are based on three different empirical studies: (a) representative survey on 238 solar self-construction households in Styria, Hackstock et al., 1992, op. cit., Ref. 16; (b) 71 face-to-face interviews with adopters and non-adopters in Lower Austria, M. Ornetzeder \& R. Hackstock, 'Solaranlagenverbreitung im internationalen Vergleich. Technologieorientierte Strategien zu einer zukunftsfähigen Entwicklung', Soziale Technik, 2, 1995, pp. 13-15; and (c) written questionnaire returned by 519 Upper Austrian homeowners, B. Pasler, 'Diffusion of Solar Collectors in Households', unpublished Master Thesis, University of Economics and Business Administration in Vienna, 1995 


\title{
Green Buildings in Context: Improving Social Learning Processes between Users and Producers
}

\author{
HARALD ROHRACHER and MICHAEL ORNETZEDER
}

\begin{abstract}
Based on quantitative surveys and semi-structured interviews with present and potential users of low energy buildings, with designers, planners, and manufacturers, this paper analyses the way use and acceptance of sustainable buildings is framed by socio-technical contexts and the way user needs are negotiated and taken into account in the design of balanced ventilation systems - arguably crucial components of sustainable buildings. A central claim of the paper is that the introduction of low-energy house technologies will be more successful, if it is organized as a mutual learning process of component producers and users.
\end{abstract}

\section{The Road to Sustainable Buildings}

The way the issue of sustainable buildings and energy efficiency is mostly discussed may roughly be divided into three strands of arguments: technical, behavioural, and urban planning (see Gestring et al., 1997):

1. Most dominant is a technical strategy, which focuses on the use of environmentally friendly materials, thermal insulation of buildings, energy efficient heating and lighting, balanced ventilation systems, etc. Architects, planners and energy experts often hold the opinion, that this strategy is the most favourable one; for example, better insulation of a building significantly improves its environmental performance without affecting the use of the building and consequently without needing the cooperation of users after the technology has been implemented.

2. Separated from the technical strategy there is a social strategy, which puts its main emphasis on the behaviour of users lowering temperature in rooms not often used or not used over night, avoiding waste, using public transport, buying energyefficient refrigerators etc. Many educational efforts and information strategies are targeting attitudes of users and aim at behavioural changes. However, as it often turns out, even if one manages to raise environmental consciousness the links between attitude and behaviour are rather weak and depend on various contextual factors (Kempton et al., 1992).

3. Finally there are strategies of urban planning. These are often separated from activities focusing on sustainable buildings, which tend to deal with buildings in isolation from their urban and local context.

All these strategies are specific translations of a rather broad and diffuse notion of sustainability into practice. As Hajer (1995/96, p. 27) rightly stresses, the politics of sustainable development have 'become a matter of how this notion congeals, how the language of sustainability solidifies in new technologies, new fiscal regimes, new socio-cultural practices'. The 
separation of technical and social strategies, with technical concepts dominating, certainly can be seen as a specific type of solidification of the discourse of sustainability, not only reflecting interests of involved actors but also dominant ways of how technological problems are perceived in our society. R\&D programmes, such as the Austrian programme House of the Future a research and development programme on which this paper is based - also contribute to the institutionalization of the strategies mentioned above. They finally result in some type of top-down engineering approach - be it a technical optimization of the energy consumption of a building, or a behavioural optimization of the way users are intended to act in such buildings.

Based on two recently finished sociological research projects on the diffusion of green buildings and balanced ventilation systems in Austria (Ornetzeder et al., 2001; Rohracher et al., 2001), we will argue that the success of these very-low-energy buildings is put at risk by focusing too narrowly on technological optimization and expected user behaviour. As surveys and qualitative interviews show, users of such buildings develop their own views and perspectives on energy efficient buildings and the technologies involved. Different groups of users may develop diverging patterns of use of these technologies and buildings and may attach different symbols and meanings to them. Consequently the concept of sustainability upon which these buildings are based is contested by users in various ways.

Traditional strategies of optimizing either technology or behaviour are often 'blind' about interactions between the spheres of the social and the technical, such as evolving and changing patterns of use of new technologies or conflicts between designers and users about the visions guiding the development of new products.Chances to introduce buildings with user high acceptance can be increased by viewing the design and diffusion of sustainable buildings as a social process and not just as realizations of technical concepts of "sustainability. This means putting more emphasis on the way such buildings are socially contextualised, i.e. on the way people start making sense of these buildings, the way they use and appropriate' them, the way such buildings are embedded into existing institutional frameworks and building traditions. Only if these experiences are fed back into the design of green buildings, leading to a learning process between the different groups of actors involved, will a fruitful co-evolution of technology design and use become effective and will the chances of a broad dissemination of such buildings increase.

The following sections present two case studies, which give evidence of the diverse ways of appropriating sustainable buildings and their technical constituents. These studies demonstrate how much the perception and acceptance of the buildings by their users and consequently the buildings' environmental effectiveness - depends on their social context and on the opportunities users have at an early stage to engage with the novel features of the buildings. In a final part models and experiences of active user involvement to improve the interaction and learning of users and designers will be presented.

\section{The Social Embedding of Sustainable Architecture: Three Socio-technical Types of Green Buildings}

The first case study is based on a survey of about 400 households in environmentally advanced buildings in Austria. In general, results show that the use of green buildings is still limited to a very specific part of the Austrian population. Most respondents are between 30 and 45 years old, educated above average and have a higher-thanaverage family income. Users of green buildings are generally environmentally conscious and well informed about ecological issues. However, even for this 
specific group of users, who can be regarded as typical innovators or early adopters, the dominant motive to move into such a building is not sustainability but rather traditional motives such as the desire for more space to live in, mainly when the family situation changes, or the location of the building.

Even though users of green buildings are a very homogenous group compared to the average population, there are significant differences mainly based on different types of organizational settings. One of the dominant splits may be observed between owners of buildings and tenants: within the sustainable buildings covered by the survey, ecological motives are much less important to tenants than they are to owners of flats or houses. The latter intensively study ecological questions after their decision to build or buy a house. Almost every house owner reports that the new and ecologically optimized dwelling is much better than the previous one, particularly with regard to comfort, energy-saving, and ecological standards.

The manner in which technological innovations are perceived and the question of whether or not they are accepted as appropriate solutions thus strongly depends on their 'social embedding'. Sustainable architecture in Austria mainly takes place within three typical settings: group dwelling projects, single-family houses, and large volume residential housing projects. These three types are not only different from a technical point of view, but the social and organizational context differs considerably.

- Group dwelling projects (eco-villages) are in most cases based on private initiatives. Projects like this were the pioneers of green architecture and the ecological aims of such projects still are very ambitious. Even extremely uncommon ecological concepts, such as low-energy earth houses, have been realized. A several-year-long discussion, learning and decision process is the central organizational component of group dwelling projects. All group members have to deal with ecological, social, and technical issues to some extent during that process.

- In the case of ecologically optimized single family houses private builders are responsible for the project. Almost every private builder is deeply involved not only in the planning process but also in the following construction work. The prospective users are able to realize many of their individual ideas. In comparison with group dwelling projects there is more place for individuality but not for a mutual learning process within a group. As a result, most of those concepts are guided mainly by a technical strategy, which focuses on the use of energy saving devices, thermal insulation, and of environmentally friendly materials.

- In large volume residential housing projects potential users are normally not involved in the planning process of the building. Residents have to decide on a nearly finished flat. The investor develops the concept of the building in co-operation with architects, building technology planners, energy experts, and structural engineers. All major issues are decided by professionals. The investors are interested to realize innovative technological concepts, on the one hand in order to demonstrate that a specific technology works on a large scale, on the other hand as a well-known green building helps to enhance the prestige of the company. While buildings of that type are generally equipped with the latest energy saving technology, the use of environmentally friendly materials is rather unusual.

If single-family houses, large volume residential housing projects developed by building societies, and community projects with small groups of people jointly developing their own housing project are compared, the differences in the perception 
of the general dwelling situation are remarkable. The highest level of satisfaction with the present living situation is articulated by single-family house occupants; participants of group dwelling projects are less content, while the relatively lowest level of contentment, partly due to technical problems, is stated by tenants of large buildings. Owners of single-family houses explain their satisfaction in terms of the suitability of the project's concept, the high quality of the rooms, the comfort of the house, and the possibility to direct the planning process. Compared with this, satisfied residents of eco-villages attribute this situation most of all to the positive effects of the social community in the project. Arguments which stress the good technical concept of the project, the high living-quality, and the existence of a private garden, are much less important. A relatively large group of dissatisfied users can be found within large ecological buildings. Only half of the tenants would choose to move into the present flat again whatever the circumstances, while 13 per cent would actually considering moving to another dwelling. Residents attribute these problems to bad planning, causing noise problems, insufficient heat supply in winter, or overheating in summer. Less livingspace, missing public transport, and little support by the housing association are further reasons to be dissatisfied. As a consequence such blocks of flats are often used in a much less ecological way: ventilation systems are blocked or turned off, electrical heaters are added to the existing system and energy consumption does not significantly drop, even though the building envelope is highly insulated.

The prospective users of group or singlefamily projects often have extensive possibilities for participation during the planning period, which prospective tenants of large volume buildings do not have. Having to deal with technological questions of green buildings, users often undergo learning processes that result in a stronger support for innovative technologies and an adequate approach to the technical equipment of the house. Our empirical material shows clearly that there is a correlation between learning processes during planning and construction of green buildings and the behavioural patterns during usage. More than 60 per cent of all users of group or single-family projects report that they have changed their behaviour to a more ecologically sound lifestyle in the last years. In large volume buildings this was the case for only 43 per cent of the respondents. That is to say that the social context of construction, for example the possibilities for prospective users to decide on technological options and participate in the planning process, has major effects on the environmentally sound operation of the building and the behaviour of its users. As we will stress at the end of this paper, changing this social embedding of the construction of large-volume buildings by, for example, introducing more participatory elements may lead to an ecologically more viable appropriation and use of such buildings.

\section{The Case of Balanced Ventilation Systems}

As a second case we will analyse the use and social contextualization of one of the arguably crucial components of very-lowenergy buildings and especially passive houses - balanced ventilation systems with heat recovery.

Passive houses are some kind of technological guidepost (Sahal, 1985) in the current discussion about sustainable buildings, at least in Austria and Germany - seen as the future standard by one group, much disputed by others. Such houses are highly insulated and optimize gains from solar radiation. Moreover, a balanced ventilation. system leads incoming and outgoing air through an efficient heat exchanger recovering up to 90 per cent of the energy traditionally lost through ventilation. These 
measures result in a very low demand for heating energy - generally below 15 $\mathrm{kWh} / \mathrm{m}^{2}$ /year, which may be provided exclusively through the ventilation system. Although the take up of such buildings is rising, it is still below expectations and the concept of passive houses is highly contested within the building community.

It is the prominent role of the ventilation system which is at the core of many disputes and makes a difference in the use of passive houses compared to more conventional buildings. The main components of ventilation systems are not new (albeit continually improved) - in Scandinavian countries in about 150 households show, this transfer to a new context is far from being a straightforward process.

Having to re-open the black-box of the ventilation system when transferring it to a new socio-technical environment means that expectations and images of how the product should be used, how it should be integrated into the building, and how, ideally, it should look may become incongruent between producers, intermediaries (architects, installers), and users. If they are to be successful, these systems have to be technically adapted and socially embedded again in an interactive learning process.
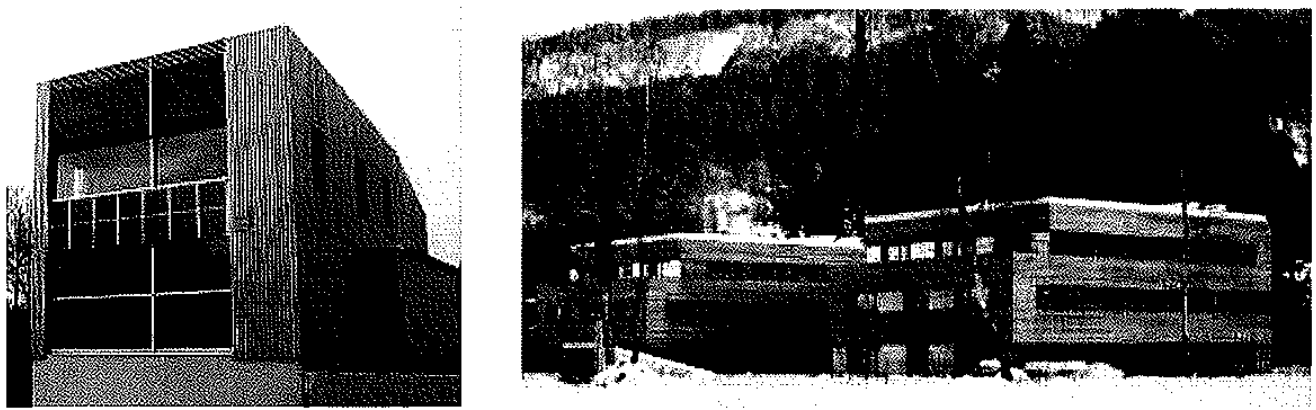

Figure 1. Two recently finished passive houses in Austria. (Architects: poppe*prehal, Zweier)

particular they have been in wide use for more than 20 years. What requires new social embedding and new practice of usage is the fact that these products have been transferred to a new context: from the Scandinavian building tradition with its emphasis on indoor air quality to an Austrian tradition with hardly any ventilation systems in residential buildings at present and much stress on the durability and quality of the building, as most people plan to stay in a building for the rest of their lives. Moreover it is a transfer from office buildings, where such systems have been used in Austria, to residential buildings with new requirements regarding use or price. As our qualitative interviews with component producers, architects, planners and users, and a quantitative survey of
The task of developing routines, practices and design visions related to these products is relevant to both the planning/ implementing of ventilation systems and their use. It is astonishing that even for such a comparatively simple product there is such a wide range of questions of design and implementation that need to be decided. Should it be designed as a central system for a large building or decentrally in each flat? How much effort should be put into noise reduction? How is the heating system integrated (independently of the ventilation system, heating purely via mechanical ventilation, or some kind of reduced conventional heating plus heating with ventilation)? What possibilities of regulation and control do users have? How is maintenance organized? and so on. 
Even with standardized components the final product is strongly dependent on planning practice and decisions taken during this process. As a result, even the technical operation of a balanced ventilation system is influenced by the social organization of constructing a sustainable building; for example, on questions such as: is it possible to organize a coherent and integrated planning process which does not separate architectural planning from the planning of building services? How is the collaboration of various professions institutionalized? Who controls certain quality standards? How is the actual construction process supervised? Thus, innovation of such products means not only improvement of the technical hardware but social innovation, or better - improvement of the socio-technical product 'the balanced ventilation system'.

However, new planning routines and practices cannot be developed on technical and economic considerations alone. If ventilation systems and buildings that depend on them are to be widely accepted, these practices have to evolve in close interaction with users, who also have to find appropriate ways of handling it, of integrating it into daily practice and of making sense of it as an ecologically friendly product. As our interviews showed, potentials for such interaction and learning processes are only harnessed suboptimally by producers, planners and other actors involved.

Many of the planners and producers merely focus on technical optimization and do not take into account the active role of users. Again, owners of houses have different opportunities from tenants in large buildings to learn about these products and to appropriate them. As a consequence, our survey showed that almost every house owner would install a ventilation system again, whereas only half of the dwellers in flats would opt for it again, if they had the opportunity. Moreover, for many inter- viewees, especially for tenants, the product was problematic in certain aspects - views that often were contested by planners and designers. To name a few:

1. Noise problems. Though properly planned ventilation systems may run extremely quietly, many users complained about noise. Sound may originate from fans in the central unit or from air outlets in rooms. Even if the noise level is very low, the effect is enhanced by the high quality of the building envelope and windows, keeping out noise from outside. Consequently many people are troubled by hearing ventilation sounds before falling asleep or when reading a book. Interestingly the problem of noise was often denied by planners, who argued that noise levels would be firmly within the requirements of technical norms (though these were set up mainly for offices). Planners and architects tended to take technically ideal products as their reference products, even if the average case of building practice was way off this mark.

What we can observe here, are disputes between designers and users about what appropriately low noise levels would be and about differing sensitivities and situations, where some users can be distracted even by very low noise.

2. Opening windows. Though in all cases it was possible to open windows, designers sometimes advised that windows be kept shut (as the ventilation system then would be more efficient and as there anyway was no need to open windows anymore). Though dwellers could open windows whenever they liked, they felt patronized just as they thought the designers of these systems would like them to behave differently. Perceived restrictions on user autonomy were also important in trying to influence the discourse about ventilation systems - people opposing it called it forced ventilation whereas producers talked about 'comfort ventilation'. 
One of the situations also leading to complaints was the wish of many people to have windows slighty open in the sleeping room even in winter, as they claimed to sleep better at low temperatures. With passive houses this is problematic as in this case temperature drops all over the house and only slowly rises the next day. Contrary to this complaint ventilation experts contend that such habits are irrational and the effect that would make people sleep well was the low $\mathrm{CO}_{2}$ concentration and not cold air, so ventilation systems should do as well. This dispute sometimes takes a physical form as some of the users block the ventilation in sleeping rooms, thereby reducing the performance of the whole system.

3. Air heating. Special problems may occur if the ventilation system is also used as a heating system in passive houses. Common problems are dry air (resulting from high air exchange rates of badly planned systems), long reaction times of the heating system, lack of means to regulate different rooms separately, constant temperature in all rooms (no warm places). Using the ventilation. system for heating purposes definitely requires changes in user behaviour and is very sensitive to planning mistakes. Many users thus insist on at least installing some elements of conventional heating systems (e.g. radiators in the bathroom) or adding electric radiators thus seriously decreasing the environmental performance of the building.

To sum up: there are certain userexpectations which diverge from those of designers and architects; there are controversies between users and designers, controversies which are about the autonomy of users (what is the user allowed to control by himself/herself), about building automation and technization of housing, and about different definitions of comfort (noise, tilted window in sleeping room). Depending on the reactions of actors involved, such controversies may lead to improved ven- tilation systems or - as many cases demonstrated - to a usàge of the system, which does not lead to the intended environmental benefits.

Again, these user perceptions were far from being homogeneously distributed. As with overall satisfaction, the perception of negative effects differed significantly between tenants and owners of buildings or flats, i.e. between users in different social and institutional contexts. Tenants appeared to be much more affected (and worse off regarding their power to initiate improvements) and more often voiced dissatisfaction with the ventilation system installed than house owners. Nevertheless, in cases where effort was put into involving tenants at early stages and, after moving into the flat, more improvements were made, satisfaction was much higher.

Moreover, the connotations with the ventilation system, i.e. what the system meant to these different groups of users, differed significantly. Whereas house-owners related ventilation systems to comfort and a healthy indoor environment, dwellers in flats mainly attributed notions of modernity and latest technology to these systems.

Apart from attributing different meanings to balanced ventilation systems occupants were not just passively affected by these products. Quite often users were looking for ways to influence the performance of the ventilation system. As already mentioned, there were people who tried to block the system in sleeping rooms, those who changed the use of rooms (children had to move to warmer rooms), or those who tinkered with possibilities to regulate temperature and ventilation levels separately in different rooms. Again owners of houses or flats were much more active in engaging with alternative technological solutions and often showed high technical competence.

It is difficult to talk about the acceptance of a technology or product in isolation from user attitude and action. There are significantly different levels of engagement 
with ventilation systems by different user groups. These levels of engagement, which to a large extent depend on issues such as ownership of a flat or the possibility to participate in the planning process, strongly influence the perception of the system and also its operation and effectiveness. The relation between this product and its users is apparently a far more active one than initially expected.

\section{Involving the Users}

The remarkable differences in attitudes to balanced ventilation systems between these user groups indicates the extent to which the effectiveness of environmental technologies may depend on the context of its appropriation. Users who get involved with planning processes and decisions about the way technologies are implemented are far more prone to integrate those technologies into their daily lives, to adapt those technologies to their needs or to forgive problematic features, such as slow reaction times of heating systems.

From the perspective of social theories of technology, the attitudes and activities of users of balanced ventilation systems can be analysed in terms of a drama between designers and users (Pfaffenberger, 1992). 'Programs and antiprograms of action', as they are sometimes called (Latour, 1992), are about ways to use ventilation systems (in a predetermined or an autonomous way), about symbolic ascriptions (living standard, environmental friendliness) and integration in specific discourses (e.g. modernity of building automation, future of housing, ecology). Clearly such struggles are also about power relations - between users, planners/architects, and producers. Moreover, it has become clear that in such a situation users are not a homogenous group with the same interests and perceptions.

The question is whether these disputes could not be turned into more effective learning processes between users and pro- ducers, if better platforms for the interaction of designers and users were provided and the involvement of users in product development was fostered. This would also mean shifting more power to consumers, supporting them in voicing their needs and actively using their experience with certain products. As a number of existing examples shows, directly involving users in the planning and construction process may improve the quality of buildings and technologies and the motivation and identification of users. The development of the new sustainable urban district of Vauban in the German town Freiburg is an excellent example of comprehensive citizen participation (Sperling, 1999). The following section sketches the broad range of possibilities to increase user involvement by participative procedures.

\section{A Participation Model for Large Volume Housing Projects}

In general it may be assumed that more user participation will lead to sound results only if the actors responsible for the development, planning and construction of dwellings actively support this process. This entails not just the willingness to make planning results and professional expertise available, but also the will to integrate user feedback and needs in further stages of the job. Interactive learning processes can take place only when there is a willingness on the part of both professionals and users to accept the others' perspective. Beyond this, planners must accept users in their role as experts in certain matters.

The participation models ${ }^{2}$ presented here are tailored specifically to involving users in the development and implementation of innovative large volume residential housing projects. The intention is to

- confront technological design even at an early stage with aspects of use, thus providing incentives for socially acceptable solutions; 
- discuss and better implement the idea of sustainable development in the field of housing construction;

- give future users a stronger voice in development, in the expectation that this will have positive effects on the way individuals deal with innovative technology during the use phase.

Our considerations cover four entry points for participation according to the phases of the standard innovation model:

1. Research and development

2. Planning

3. Construction and

4. Use of the buildings

For each of these phases, concrete tasks, methods of implementation and potential groups of participants are suggested in table 1. It appears to be appropriate to involve representative experienced users in early phases of development. The farther the project progresses towards realization, the more sense it makes to involve prospective users of the building in the planning process. Both forms of participation may improve the social embedding of innovative building concepts.

Depending on the development phase of the project, various groups of users may deal with different topics using suitable methods in each case. The following details of the participation model are limited to the research and development phase, since exemplary focus group discussions, as outlined below, were carried out in this area. ${ }^{3}$

While the project is in the development stage, the main goal is to clarify fundamental questions. According to Sclove (1995, p.181), R\&D processes profit from participation in a threefold manner: first, by the participation of a large number of individuals, representing a broader spectrum of viewpoints; this increases the odds of discovering creative solutions with a high degree of innovative potential. Second, it ensures that existing social needs and

Table 1. User participation toward developing and implementing building concepts.

\begin{tabular}{|c|c|c|c|}
\hline Phase & Topics & Methods & Participants \\
\hline $\begin{array}{l}\text { Research and } \\
\text { development }\end{array}$ & $\begin{array}{l}\text { - future needs } \\
\text { - achieving sustainability } \\
\text { - evaluating architectural } \\
\text { concepts }\end{array}$ & $\begin{array}{l}\text { - open space } \\
\text { - future workshop } \\
\text { - target group participation } \\
\text { - planning cells } \\
\text { - focus groups }\end{array}$ & $\begin{array}{l}\text { - experienced users, lead } \\
\text { users } \\
\text { - representatives of interest } \\
\text { groups } \\
\text { - intermediate users }\end{array}$ \\
\hline Planning & $\begin{array}{l}\text { - development of } \\
\text { construction and usage } \\
\text { concepts } \\
\text { - evaluating construction } \\
\text { details } \\
\text { - evaluating energy } \\
\text { concepts }\end{array}$ & $\begin{array}{l}\text { - planning for real } \\
\text { - moderated planning } \\
\text { workshops } \\
\text { - focus groups } \\
\text { - moderated co-housing } \\
\text { groups } \\
\text { - residents committee }\end{array}$ & $\begin{array}{l}\text { - experienced users, lead } \\
\text { users } \\
\text { - intermediate users } \\
\text { - future users }\end{array}$ \\
\hline Construction & $\begin{array}{l}\text { - choice of materials } \\
\text { - floor plans of dwellings } \\
\text { - concepts for free space } \\
\text { - community facilities }\end{array}$ & $\begin{array}{l}\text { - residents committee } \\
\text { - moderated co-housing } \\
\text { groups }\end{array}$ & - future users \\
\hline Usage & $\begin{array}{l}\text { - information for residents } \\
\text { - feedback from users }\end{array}$ & $\begin{array}{l}\text { - information workshop } \\
\text { - feedback on experience } \\
\text { - post-occupancy evaluation }\end{array}$ & - users of the building \\
\hline
\end{tabular}


experiences are reflected and respected. And third, the participation of quite different players makes it more likely that ideas are transferred from one area of society to another. Possible topics at this stage are related to the future needs of users, to paying greater attention to sustainability criteria in the conception of dwellings and to evaluating building concepts which have already been developed.

The choice of methodological approaches will be determined substantially by the topic at hand. Approaches such as the Future Workshop (Jungk and Müllert, 1989) or Open Space (Owen, 1997) are suited to gathering concept ideas and future needs. If the aim is to pay more attention to sustainability, methods such as the Planning Cell (Dienel, 1993) and target group participation (Sperling, 1999, p. 49) are appropriate. Focus groups or a series of focus group sessions (Dürrenberger and Behringer, 1999) are suitable for discussing and evaluating concepts which have already been developed.

Three user groups in particular may be considered for participation during this phase: experienced users (lead users, final users) who have been able to gather tangible experience with similarly designed buildings and are interested in technological questions; representatives of interest groups, particularly those involved in the promotion of 'sustainable development'; and intermediate users such as developers, housing societies and construction companies.

\section{User Participation by Means of Focus Group Discussions: First Experiences}

We will conclude with some experiences gained with two focus groups assessing concepts of planned sustainable buildings. These two groups were set up within the Austrian programme House of the Future as an experiment to involve representative users of ecological dwellings into planning processes of sustainable buildings. The focus groups consisted of six people, giving them the opportunity to interact (cf. Gibbs, 1997, p. 2), to ask each other questions, reconsider existing views in the light of new arguments and if necessary revise these views. All of the participants had several years (between one and 12 years) experience with ecologically optimized dwellings.

Both housing projects considered by the focus groups were potentially innovative, large volume residential buildings. When the discussions took place the buildings were still at a conceptual stage with no detailed planning or drawings. Project ideas were thus presented orally at the beginning of the discussions by representatives of the two projects.

Contributions to the discussion concerned both the concepts in general and individual aspects such as possible construction details, which the participants discussed and evaluated on the basis of their own experiences. Current practice with respect to participation in large volume housing projects and its significance was broadly treated in both discussion groups. All participants held the opinion that a voice in planning is very important particularly in innovative model projects and would influence the extent to which objectives such as energy savings are met.

Three main types of outcomes of the focus group discussions may be differentiated. First, the concepts presented were evaluated. Second, participants named qualities desirable for significantly increasing the attractiveness of the projects from a user's point of view. Third, in the course of the discussions users brought in their own actual experiences thereby substantiating critical evaluations as well as illustrating desired positive characteristics.

The two focus group discussions showed that it is feasible and worthwhile to allow users to evaluate housing concepts from their point of view even at a very early phase of development. Even though neither plans, models nor photos of the planned 
buildings were available, the participants, keenly interested as they were, came to grips with the concepts relatively swiftly by means of well-targeted questions. Participants were able to name conceptual deficiencies quickly and to discuss suggestions for changes on the basis of their experiences. They were able to evaluate the concepts independent of personal interests, particularly since they themselves would never live in the planned buildings. Despite the plethora of results obtained in the present case it seems generally advisable to carry out more focus groups (at least three) with different participants in each case.

\section{Conclusions}

As our research shows, the process of setting sustainable buildings and their components within the social context - the way people learn to make sense of them, the way they develop patterns of use and how they integrate them into their daily practice makes a big difference to the acceptance of these buildings and chances for their wider dissemination, and also to the question of whether these buildings are sustainable in their real and effective use. This process of contextualization depends on the characteristics and specific situation of different user groups - be they tenants, owners of single-family houses, or members of community projects. According to these different settings we can observe diverging perspectives and negotiations about sustainability, comfort or autonomy, which in turn shape the way these buildings are constructed and the technologies used. One of our main points is that the way the concept of sustainable buildings/passive houses is negotiated has influence on the user acceptance of these buildings and on the technologies employed. Institutional and organizational settings for these negotiations and mutual learning processes have been developed within building traditions that did not so much rely on user satis- faction and comoperation but rather focused on providing living space rapidly.

Consciously involving users appears to be one way to improve the process of social contextualization, to adapt technologies better to the needs and perspectives of specific user groups, and to enhance the chances for a more sustainable use and wider dissemination of such buildings. As presented in the matrix above there are various opportunities in the process of constructing sustainable buildings, where users - representative users, who already live in a green building, or potential users of a planned building - can be involved. At the very least, such an explicit participation of users in development and planning processes may result in learning processes between component producers, builders, planners and users, and may serve to develop technologies and building designs that are sustainable not only as abstract concepts but also in construction and use.

\section{NOTES}

1. For a more detailed discussion on the concepts of appropriation and domestication see Lie and Sørensen, 1996, or Mackay and Gillespie, 1992.

2. We would like to thank Johan Schot for helpful discussions.

3. An extensive presentation of the participatory model may be found in Ornetzeder, M. et al. (2001).

\section{REFERENCES}

Dienel, P.C. (1993) Die Planungszelle. Der Bürger plant seine Umwelt. Eine Alternative zur Establishment-Demokratie. Opladen: Westdeutscher Verlag.

Dürrenberger, G. and Behringer, J.(1999) Die Fokusgruppe in Theorie und Anvendung. Stuttgart: Akademie für Technikfolgenabschätzung.

Gestring, N. et al. (1997) Ökologie und urbane Lebenszveise. Untersuchungen zu einem anscheinend unauflöslichen Widerspruch. Braunschweig: Vieweg. 
Gibbs, A. (1997) Focus groups. Social Research Update, No.19, Winter. http://www.soc.surrey. ac.uk/sru/SRU19.html.

Hajer, M. A. (1995/96) Politics on the move: the democratic control of the design of sustainable technologies. Knotoledge and Policy, 8(4), pp. 26-39.

Jungk, R. and Müllert, N. (1989) Zukunftswerkstätten. München: Heyne.

Kempton, W., Darley, J.M. and Stern, P.C. (1992) Psychological research for the new energy problems. Strategies and opportunities. American Psychologist, 47(10), 1992, pp. 1213-1223.

Latour, B. (1992) Where are the missing masses? The sociology of a few mundane artifacts, in Bijker, W.E. and Law, J. (eds.) ShapingTechnology/ Building Society. Studies in Sociotechnical Change. Cambridge, MA: The MIT Press.

Lie, M. and Sørensen, K.H. (1996) Making technology our own? Domesticating technology into everyday life, in Lie, M. and Sørensen, K.H. (eds.) Making Technology Our Own? Domesticating Technology into Everyday Life. Oslo: Scandinavian University Press, pp. $1-30$.

Mackay, H. and Gillespie, G. (1992) Extending the social shaping of technology approach: ideology and appropriation. Social Studies of Science, 22, pp. 685-716.
Ornetzeder, M. et al. (2001) Erfahrungen und Einstellungen von NutzerInnen als Basis für die Entwickling nachhaltiger Wohnkonzepte mit hoher sozialer Akzeptanz. Projektbericht im Auftrag des Programms Haus der Zukunft. Wien: BMVIT.

Owen, H. (1997) Open Space Technology. A User's Guide. San Francisco: Berrett-Koehler.

Pfaffenberger, B. (1992) Technological dramas. Science, Technology, \& Human Values, 17(3), pp. 282-312.

Rohracher, H. et al. (2001) Akzeptanzverbesserung von Niedrigenergiehaus-Komponenten als wechselseitiger Lernprozess von Herstellem und AnwenderInnen. Projektbericht im Auftrag des Programms Haus der Zukunft. Wien: BMVIT.

Sahal, D. (1985) Technological guideposts and innovation avenues. Research Policy, 14, pp. 61-82.

Sclove, R. (1995) Democracy and Technology. New York: Guilford Press.

Sperling, C. (ed.) (1999) Nachhaltige Stadtentwicklang beginnt im Quartier. Ein Praxis- und Ideenhandbuch fuir Stadtplaner, Baugemainschaften, Bürgerinitiativen am Beispiel des sozialökologischen Modellstadtteils Freiburg-Vauban. Freiburg: Öko-Institut. 


\title{
Sustainable technology and user participation. Assessing ecological housing concepts by focus group discussions
}

\section{Michael Ornetzeder}

\author{
Centre for Social Innovation, Vienna, Austria
}

\begin{abstract}
For the social acceptance of new technological solutions it is of decisive importance to deal with users' needs and experiences at the earliest possible stage. In the following article the possibilities and limitations of focus group discussions as a method of participatory assessment of technology is discussed in the light of two examples from the area of ecological housing construction. A comprehensive model for participation, comprising different methods of user participation for different phases of development, serves as the theoretical framework of the discussion. The application of this model in exemplary fashion in the form of focus group discussions demonstrates that, even during a very early phase of development, it is possible and worthwhile to let experienced users assess innovative housing concepts. Three kinds of results are differentiated: concept assessments, desired qualities and reports involving users' individual experiences.
\end{abstract}

Keywords: 


\section{Introduction}

Ecologically optimised housing must not only fulfil criteria derived from environmental technology, it should in addition meet widespread acceptance within the population. Particularly within the area of large volume housing projects, however, drawing on the knowledge gained from users' experience already at an early stage in the project has been attempted in only a few exceptional cases up to now. In the cases of single family dwellings and ecological group housing projects, technological innovations are implemented only after consciously involving the later users of these dwellings. Yet in the case of large volume housing construction, dwellings are produced for a certain standard user or just generally for the "housing market". Even in the case of concepts involving sophisticated environmental technology, later users are normally confronted with the buildings once they have been completed and are in the process of being marketed. Nor is experience with dwelling in similar projects referred to as a rule either.

This situation is peculiar to the extent that social scientists in the context of innovation research have repeatedly pointed out that users' experience represents a significant pool of knowledge for technological innovation processes. For, on the one hand, paying attention early on to users' specific requirements improves the social acceptance of new technology. On the other hand, certain solutions are initiated only due to the active role of certain groups of users. This new aspect has influenced views as to when and with which strategies the development of technological innovations may be carried out. Classical concepts of technology assessment based primarily on the knowledge of experts have increasingly become complemented by participatory elements.

The possibilities and limitations of focus group discussions as a method of participatory technological assessment are discussed in the present article in the light of two concrete examples. The two discussions were carried out as part of a research project on the topic of social acceptance of innovative, environmentally friendly housing units within the framework of the programme "Haus der Zukunft" ("Building of Tomorrow") initiated by the Austrian Federal Ministry for Transport, Innovation and Technology. ${ }^{1}$ Experienced residents of ecological buildings discussed two innovative building concepts for constructing ecologically oriented multi-story dwellings.

In the first part of this paper, the programme "Building of Tomorrow" is presented briefly. For this primarily technological research programme a model for participation was developed, aiming to involve various groups of users in the different phases of development during the innovation process. The experiences gained in dealing with focus groups which are presented in the second part of this article represent a first application by way of example of this method of participation.

1 The project entitled "users' experiences and attitudes as a basis for developing sustainable dwelling concepts with a high degree of social acceptance" was commissioned by the Federal Ministry for Transport, Innovation and Technology and carried out by the Centre for Social Innovation (Vienna) in co-operation with the Inter-university Research Centre for Technology, Labour and Culture (Graz). The project was completed in April 2001. The following individuals were involved in the task: Uli Kozeluh, Bernd Kumpfmüller, Irene Schwarz, Michael Ornetzeder, Harald Rohracher. 


\section{Ecological construction within the programme "Building of Tomorrow"}

In 1999 the Austrian Ministry of Science launched an impulse programme on the subject of sustainable economic activity, originally stated for five years. The first emphasis dedicated to the topic of the "Building of Tomorrow" aims to develop and implement innovative, sustainable residential and office buildings. As defined within the impulse programme, sustainability refers to: an increasingly efficient consumption of energy with respect to the entire life cycle of the building; a greater use of renewable sources of energy (especially the use of solar energy); the greatest possible use of organically renewable raw materials as well the efficient use of materials; and increased attention to service and use from users' point of view. Conceptually speaking, this broader perspective finds its foremost expression in social science research projects which accompany the project. The research emphasis "Building of Tomorrow" aims primarily at developing and promoting the market diffusion of components, construction elements and methods for residential and office buildings which conform to the highest possible degree to the guidelines for sustainable development (BMWV, 1999). Drawing on the basis of developmental principles encompassing a broad field of subjects, the authors designing the programme were, however, aware that they would have to seek solutions oriented not only on technological criteria. Research and development with the goal of sustainable development requires balancing a variety of interests. The resulting search for new priorities deemed necessary is described as follows:

Co-ordinating these requirements is highly demanding and entails conflicts in goals for which solutions need to be found which will meet with a consensus of approval. On the other hand, integrating social, economic and ecological goals represents a significant opportunity, whereby the key to success lies in innovation, yet not alone in a technological sense, but rather here once again in combination with social, economic and institutional innovation. Particularly by combining the afore mentioned criteria, the door is opened for achieving technological advances with great potential for marketability (BMWV, 1999, p. 3)

One possible strategy for achieving the objectives stated here is to open up the process of technological development to new players. Thus, attention could be paid in particular to users' perspective at the earliest possible stage in order to avoid acceptance problems when developing and implementing innovative building concepts. Within the framework of the above-mentioned research project a model for participation for the entire research programme was therefore developed on the basis of international experience. This model included discussing different options for involving the various user groups in the process of technological development. Two innovative building concepts were selected and assessed by experienced users within the framework of focus group discussions toward the end of putting the model into practice in exemplary fashion. This procedure made it possible on the one hand to gather practical experience with user participation by means of focus group discussions, and on the other hand to produce the first tangibly useful results of project-related feedback. 


\section{User participation in the case of innovation processes}

Recent studies in the area of innovation research assume that technological development processes can derive substantial profit from direct user participation (e.g., Akrich, 1995; Schot, 1998; Weyer et al., 1997). In particular, users are expected to present arguments serving to improve the social acceptance and user friendliness of new technologies. Beyond this, one may also reckon with encountering unconventional and for the most part novel suggestions for improvement. This assumption is based on the premise that technological innovations are essentially to be interpreted as the result of social processes deriving from economic interests, political power constellations and cultural value concepts. Yet the interests and experience of users are taken into account to only a small degree as a rule, even though each user of a technology possesses valuable expertise in his or her specific area. Users are experts on the user context of technologies (see Bijker 1996). Building upon this insight, new approaches in the field of technology assessment (TA) have been developed in recent years, no longer concentrating on the evaluation of new technologies, but rather focussing on the processes by which technologies arise and, beyond this, attributing to the potential users of such technologies a significant role (e.g., "Constructive Technology Assessment" in the Netherlands or "innovationsorientierte TA" in Germany). By thus broadening the design process, possible problems arising only within the corresponding contexts of use are to be recognised at an early stage and are to be minimised by making appropriate changes. Technological assessment thus becomes increasingly a participatory process, systematically nurtured not only by scientific knowhow but also by the everyday experiences of technology users (see Bröchler \& Simonis, 1998).

As a rule, experts in planning (architects, building technology planners, energy experts, structural engineers) are exclusively involved in the early phases of building development. For this reason, users along with their experiences and needs are taken into account only indirectly or in biased fashion. Madeleine Akrich (1995, p. 173ff) speaks in such cases of implicit user representation, discerning three typical approaches:

(1) Designers see themselves as "normal users," attempting in this way to anticipate the possible needs and experiences of future users.

(2) Certain experts for user questions are consulted (e.g., marketing experts).

(3) Trust is placed in the (market) success of similar technologies and concepts.

These three widespread strategies for representing users and possible forms of use during technological development processes are subject to considerable uncertainties. Engineers are not able to negate their professionally trained approaches at will; marketing experts' knowledge of users is usually confined to the latter's role as consumers; and even the success of comparable solutions is nothing more than a vague guideline when developing innovative solutions. As long as technological development is embedded primarily in a culture of scientific engineering, users exist for the most part in the shape of "user images" (Hofmann, 1997). The imminent danger of planning for a fictitious standard user that in reality does not at all exist thus remains.

2 Innovation-oriented TA. 
To what extent one succeeds, parallel to technological development, in constructing socially acceptable contexts of use is, therefore, a question of paramount importance for the success of ecological architecture and technology. "Only if one succeeds," Weyer writes, "in accommodating a new technology to the behaviours of potential users in advance and, in turn, in taking into account users' interests and potential behavioural patterns in the design of the new technology does a socio-technological innovation stand a chance of succeeding" (Weyer, 1997, p. 50, see also Schot et al., 1994). The goal must be to "find out during the construction process of a new technology how later users will deal with that technology and which strategies and interests they will pursue in dealing with it. Only this type of early feedback between the user and the producer makes it possible to develop approximately realistic models of socio-technological systems" (ibid.). The manner in which technological innovations are perceived and the question of whether or not they are accepted as solutions depends for the most part on their "social embedding"; it thus hinges on the degree to which a new technology is adapted to society and, conversely, on the extent to which behavioural changes are required on the part of users. The manner in which this interactive accommodation process is organised socially and during which phase in development the process is initiated are also essential factors in this context.

\section{Elements of a participation model}

In this context, user participation is viewed not only as a specific form of participation in the sense of direct democracy, it is also recommended specifically as a strategy for technological policy. In general it may be assumed that only when those traditionally responsible for the development, planning and construction of dwellings actively support the innovation process does stronger user participation lead to sound results. This entails not just the willingness to make planning results and professional expertise available, it also means the will to integrate users' feedback and needs in further stages of the job. Interactive learning processes can taken place only when on the part of both professionals and users the willingness to accept the other's perspective is given. Beyond this, planners must accept users in their role as experts in certain matters.

The participation model ${ }^{3}$ suggested here is tailored specifically to involving users in the development and implementation of innovative dwellings. With respect to content the model seeks to

- confront technical development even at an early stage with aspects of use, thus providing incentives for socially acceptable solutions;

- discuss and implement in a broad manner the principles of sustainable development in the field of housing construction;

- give future users a voice in development, leading to the expectation that positive effects on the way individuals deal with innovative technology during the use phase will be achieved.

In the course of the impulse programme "Building of Tomorrow," building concepts are not only to be investigated but also realised and used in the form of dwellings. For this

\footnotetext{
3 We would like to thank Johan Schot for helpful discussions.
} 
reason our considerations cover the four phases of 1) research and development, 2) planning, 3) construction and 4) use of the buildings. For each of these phases, concrete tasks, methods of implementation and potential groups of participants were discussed. The results of these considerations are presented in overview in table 1 . With respect to those involved in the forms of participation recommended, it may be generally assumed that it is appropriate to have experienced users participate in early phases of development. The farther the project progresses toward realisation, the more sense it makes to involve future users in the planning process. Both forms of participation serve to encourage the social embedding of innovative building concepts.

Table 1. User participation toward developing and implementing building concepts

\begin{tabular}{|c|c|c|c|}
\hline Phase & Topics & Methods & Participants \\
\hline $\begin{array}{l}\text { Research } \\
\text { and devel- } \\
\text { opment }\end{array}$ & $\begin{array}{l}\text { - } \text { future needs } \\
\text { - achieving } \\
\text { sustainability } \\
\text { - evaluating architec- } \\
\text { tural concepts }\end{array}$ & $\begin{array}{l}\text { - Open Space } \\
\text { - Future Workshop } \\
\text { - target group partici- } \\
\text { pation } \\
\text { - Planning Cells } \\
\text { - focus groups } \\
\text { - series of focus group } \\
\text { sessions }\end{array}$ & $\begin{array}{l}\text { - } \text { experienced users } \\
\text { (lead users) } \\
\text { - representatives of } \\
\text { interest groups } \\
\text { - intermediate users }\end{array}$ \\
\hline Planning & $\begin{array}{l}\text { - development of } \\
\text { construction and } \\
\text { usage concepts } \\
\text { - evaluating construc- } \\
\text { tion details } \\
\text { - evaluating energy } \\
\text { concepts }\end{array}$ & $\begin{array}{l}\text { - planning for real } \\
\text { - moderated planning } \\
\text { workshops } \\
\text { - focus groups } \\
\text { - moderated construc- } \\
\text { tion groups } \\
\text { - residents' committee }\end{array}$ & $\begin{array}{l}\text { - experienced users } \\
\text { (lead users) } \\
\text { - intermediate users } \\
\text { - future users }\end{array}$ \\
\hline $\begin{array}{l}\text { Construc- } \\
\text { tion }\end{array}$ & $\begin{array}{l}\text { - choice of materials } \\
\text { - floor plans of dwell- } \\
\text { ings } \\
\text { - concepts for free } \\
\text { space } \\
\text { - community facilities }\end{array}$ & $\begin{array}{l}\text { - residents' committee } \\
\text { - moderated construc- } \\
\text { tion groups }\end{array}$ & - future users \\
\hline Usage & $\begin{array}{l}\text { - information for } \\
\text { residents } \\
\text { - feedback from users }\end{array}$ & $\begin{array}{l}\text { - information workshop } \\
\text { - feedback on experi- } \\
\text { ence } \\
\text { - post-occupancy } \\
\text { evaluation }\end{array}$ & - users of the building \\
\hline
\end{tabular}

Depending on the development phase of the project, various groups of users may deal with different topics using suitable methods in each case. The following details on participation models are limited to the phase of research and development, since focus group discussions were carried out in this area by way of example ${ }^{4}$.

4 An extensive presentation of the participatory model may be found in Ornetzeder, M. et al. 2001. 
While the project is in the development stage, the main goal is to clarify fundamental questions. According to Sclove (1995), R\&D processes profit from participation in a threefold manner: first, by the participation of a large number of individuals, representing a broader spectrum of viewpoints; this increases the odds of discovering creative solutions with a high degree of innovative potential. Second, it ensures that existing social needs and experiences are reflected and respected. And third, the participation of quite different players makes it more likely that ideas are transferred from one area of society to another (see Sclove, 1995, p. 181). Possible topics in this stage are related to the future needs of users, to paying greater attention to sustainability criteria in the conception of dwellings and to evaluating building concepts which have already been developed. Other topics could be developed while working with the individual project groups. Sometimes concrete decisions irreversibly influencing the direction of further research and development activities have to be taken very early in the process. In the case of a reasonably priced passive solar house, for example, it must be determined whether users would be prepared to do without an additional source of heat in the bathroom. This question can only be clarified through immediate interaction with potential residents. Experiences gained from dwellings which have already been built and the results of research on heating needs in private homes - inasmuch as such results even exist - can only be classified as additional information. Gathering current opinion at an early stage in such cases increases the efficiency of research and development work and gives way to the expectation that the concepts realised will meet with greater acceptance.

The choice of methodological approaches will be determined substantially by the topic at hand. Approaches like the Future Workshop (Jungk \& Müllert, 1989) or Open Space (Owen, 1997) are suited to gathering concept ideas and future needs. If the aim is to pay more attention to sustainability, methods such as the Planning Cell (Dienel, 1993) and target group participation (Sperling, 1999, p. 49) are appropriate. Focus groups or series of focus group sessions (Dürrenberger \& Behringer, 1999) are suitable for discussing and evaluating concepts which have already been developed.

Three user groups in particular may be considered for participation during this phase: experienced users (lead users, final users) who have been able to gather tangible experience with similarly designed buildings and are interested in technological questions; representatives of interest groups, particularly of ones involved in-depth in the subject of "sustainable development"; and intermediate users such as construction financiers, housing bureaux and construction companies which take an intermediate role between planning and usage during the planning process, offering specific expertise.

\section{An example of user participation by means of focus group discussions}

The focus group discussion is an investigative method which has rarely been used up to now in empirical social research. Even though this form of qualitative group interview was already used in the 1950s by Paul Lazarsfeld and Robert Merton to investigate audience reactions, its main field of usage for a long time was commercial marketing and opinion research. Yet in English-speaking countries in particular a great deal of experience has been gathered in applying this method. Due to the general trend toward revaluating qualitative research methods in recent years, the focus group discussion has, among 
others, increasingly come to be regarded as a serious instrument for social scientific investigation and to be used in scientific studies (cf. Catterall \& Maclaran, 1997; Dürrenberger \& Behringer, 1999; Gibbs, 1997; Hörning, Keck \& Lattewitz, 1999; Littig \& Wallace, 1998).

Focus groups consist of six to 12 individuals who discuss a specific topic under controlled conditions. The participants all have a common experience which serves as the starting point for the discussion. In our case this was the oral presentation of a building concept by each of the project managers. The moderator plays an essential role in the focus group. This individual is responsible for maintaining an agreeable atmosphere during the conversation, for channelling incipient conflicts and for ensuring that as many participants as possible become involved, while maintaining a neutral attitude in topical matters. The one- or two-hour discussions are audio- or video-recorded as a rule, transcribed and then evaluated using methods of content analysis (see Dürrenberger \& Behringer, 1999).

One of the main advantages of focus group discussions, compared with individual interviews for example, is according to the special literature on the method the opportunity to interact (see Gibbs, 1997, p. 2). Participants can ask each other questions, reconsider existing views in the light of new arguments and if necessary revise these views. A group discussion allows a learning process to take place among the participants and usually offers a more complex and differentiated picture of the points of view inherent among them.

Two focus group discussions with experienced residents of ecological dwellings were carried out in the course of the project. Two new building concepts were selected whose scientific and technical development is being subsidised within the framework of the impulse programme "Building of Tomorrow". Both projects belong to the area of large volume residential housing and each evidences a high degree of potential for innovation. Specifically, the projects are as follows:

(1) HY3GEN - a renewable house: a hybrid building (HY) of the so-called third generation $(3 \mathrm{GEN})$ is planned. The concept foresees the use of renewable materials to the greatest degree possible as well as the implementation of various solar technologies. The hybrid character of the building is found in two aspects: on the one hand, a combination of different forms of usage (commercial/residential) is planned, while on the other hand a building concept is to be implemented in which the infrastructure (i.e. utility lines, building technology, dividing walls) is independent of the building shell. This is in order to heighten the flexibility of usage as well as increasing the period of use of the building shell. Due to the combination of shopping centre, office wing and living quarters, the project requires a central location in the inner city. For marketing reasons a share of $75 \%$ commercial to $25 \%$ residential usage is to be achieved. This constellation entails 60 to 70 dwellings.

(2) Application of the passivhouse technology in social housing in Vienna: The objective of this research project is to develop an especially cost-efficient housing project complying with the passivhouse standards with around 100 dwelling units for a location in Vienna. The term passivhouse refers to a building concept entailing extremely low heat energy requirements, rendering a conventional heating system entirely superfluous (hence the term "passive"; a passivhouse does not require a conventional "active" heating system, heating itself passively for the 
most part). Remaining heat energy requirements are covered by means of a ventilation system, controlling the flow of warm air into the rooms of the dwelling. To date, no passivhouses have been erected in the framework of social housing projects in Austria.

Both of the projects began as building concepts, meaning that at the point in time when discussion rounds took place no building property had been acquired and thus no building plans or any other drawings existed either. Essentially, therefore, project ideas were evaluated which were presented orally at the beginning of the discussions by representatives of the two research projects.

The participants in the discussions were without exception users, each with their specific backgrounds of experience. All those involved had amassed several years of experience in the usage of ecological dwellings, displaying interest in the topic of discussion even in the preparatory phase. The participants may be classified as experts on the usage of ecologically optimised dwellings. While selecting the participants in the discussion rounds, care was taken to ensure the greatest possible degree of heterogeneity within a generally homogeneous target group. With respect to socio-structural characteristics the participants represented for the most part the general population living in ecological dwellings. Typical characteristics of this group are above all a high level of education, often coupled with an above-average income level. The participants were aged 35 to 50 years and most of them are employed in educational, social or technical jobs. All of the participants looked back on several years (between one and 12 years) experience with ecologically optimised dwellings. With respect to individual participants' specific background of experience, varying but in each case typical living situations were intentionally selected. Residents of large volume residential buildings, group dwelling projects (eco-villages) and in each group one of single family houses participated in the two discussion rounds. Homeowners and tenants were represented in each of the groups. Three women and three men were involved in each of the discussion groups, that is, six people in each group. Both of the discussions lasted about two and a half hours including the presentation which was focussed more sharply by means of detailed questions on the part of participants. The ensuing discussions were based on a rough question catalogue.

\section{Results of the focus group discussions}

Principally speaking, similar topics were discussed in both focus groups. The statements made concerned the concepts themselves as well as individual aspects of them and even took in possible construction details, which the participants discussed and evaluated on the basis of their own experiences.

The discussion of $H Y 3 G E N$ centred on the topic of the mixed usage of the building. The high degree of commercial usage which the operators strove for (a share of as much as $75 \%$ was planned) was repeatedly criticised as being too high. Yet not only the share of commercial usage affects the attractiveness of the project, the type and selection of commercial tenants is also of intrinsic importance. In the participants' view, the quality of the site could be greatly increased with the aid of mixed usage as planned. The participants described their vision of an exciting centre in the city quarter, including short distances to facilities and attractive offerings for residents. An urban ambient conducive to strolling, stimulating while at the same time offering opportunities to rest, should be created in 
the public area of the property. Specifically, the participants expressed a desire for shopping facilities, a market hall, a coffee house, a fitness club, a day-care centre and a school. The share of commercial tenants in the entire area of the complex should not exceed $50 \%$. Production firms not able to rule out noise and other emissions are to be largely banned. The hybrid building concept was viewed positively for the most part. The very low energy standard targeted for the building shell was judged by several participants as being an additional positive aspect. On the other hand, the share of renewable building materials was criticised as being too small. More than the planned $10 \%$ total tonnage should be derived from renewable materials in order to satisfy the project's expectations.

With respect to the passivhouse, the lack of a social concept and the overly high degree of concentration on technical aspects and low building costs were criticised foremost. All discussion participants were of the opinion that the concept, of itself positive, would be handicapped by the cost restrictions for social housing. Problems with the building's technical systems and/or cost reduction measures while erecting and furnishing the dwellings would result, greatly reducing the attainable living quality in the finished dwellings. The discussion group concluded that the project would only succeed if residents can be found early enough who are largely able to identify with the basic idea and goals of a passivhouse. In the view of some of the discussion participants, the attractiveness of the project could be significantly increased with the aid of a suitable social concept (marked by a careful selection of tenants, participation in planning decisions, technical training, counselling and advice during the residential phase). None of the participants could imagine that the building technology to be implemented would function in a fashion neutral to users' behaviour, that is, regardless of the way users' reacted the desired effects could be achieved. The participants backed up their scepticism with a number of examples from their own living experience.

Current practice with respect to participation in large volume housing projects and its significance was broadly treated in both discussion groups. All participants were of the opinion that a voice in planning is very important particularly in innovative model projects. The success of innovative projects does not, therefore, depend exclusively on planning know-how derived from engineering science and architecture and on the exact execution of building plans. With their behaviour, later residents, too, determine to what extent the original objectives (e.g., goals for saving energy) are reached. Particularly in the case of pilot and model projects, therefore, which are followed with keen professional interest, it is important to involve users in the concept. If in the framework of such processes one succeeds in stimulating learning processes on the part of those involved, this will also affect users' behaviour later on.

If the attempt is made to classify the results on a more general level, three types of results may be differentiated. First, the concepts presented were evaluated both positively and negatively. Second, participants named qualities desirable for significantly increasing the attractiveness of the projects according to a user's point of view. Third, in the course of the discussions users related their own concrete experiences, serving to substantiate critical evaluations as well as to illustrate desired positive characteristics.

\section{Evaluation of the building concepts}

The critical stances in the discussion on the passivhouse are a good example for the evaluation of building concepts. In this case, criticism was levelled at the, in participants' 
opinion, overly strong concentration on the topics of saving energy and how to reach that goal technically. Participants were of the impression that, in comparison with the technical parameters mentioned above, potential users played only a minor role. In users' view a liveable dwelling was of foremost importance, realising a building with extremely low heat energy requirements was not accepted as an isolated objective - even though all participants placed great importance on ecological living and themselves live in such buildings. One of the participants described this dilemma using a question:

A: "The question is whether this is about quality of living or technical matters. As far as we [the participants] are concerned, we all want a high living quality, and if they built long corridors like that, then there would simply be no living quality; just because they want us to use little energy, they will accept anything, that is what you mean, isn't it?"

Another participant criticised the basic approach of the project group, focussed too strongly on optimising costs and thus on technical questions. And that, even though he was aware that a research project is concerned foremost with plotting possibilities for realising the architecture and construction of the project.

B: "This is about social housing, but for me the technical part has got out of hand. But that's your part, of course, I know that. ... The problem is construction costs are limited. You've got a fixed amount, and if you spend a lot of money on technology, then that technology will take up a fair part of the budget. The result is that the general contractor looks for very cheap companies; that also happened with our building, for instance. Of the different subcontractors who built part of our building, four out of seven of them went bankrupt, so that is about standard. ... You just can't find a firm that can build it for a lower price, which is the aim in social housing projects, so that the whole thing works."

\section{Stating desirable qualities}

In stating desirable qualities, mostly topics are concerned to which attention is hardly given in the early stages of building development, generally speaking. Yet from the users' point of view they are very important because they decisively influence the usability of the building and its immediate environment on a day-to-day basis. The following quotations are derived from the discussion about the HY3GEN project. The participants developed some very definite notions with respect to the mixed usage of the building, the decoration of internal and external areas as well as to possible service offerings.

A1: I would very much like to live in an area that is not just a residential area. Car sharing in the garage would not be bad either. I like many-sidedness too, various kinds of free space and so forth.... If it's in the city, then with as much greenery as possible inside.

B1: I would prefer nice, bright rooms, good acoustical separation between the different functions [commercial/residential], a view with some green, although I 
don't care whether it grows from the side, below or above. Cocktail tomatoes on the window still would be nice.

C1: $40 \%$ firms and $60 \%$ flats would be all right. I'd like a market hall. Maybe $10 \%$ of all companies in there could be technical. There should be a Billa [supermarket], a coffee house, things, that is, that I use myself everyday.

\section{Reports of users' concrete experiences}

In the course of the discussion about the passivhouse concept the question was raised as to what influence in general users' behaviour has on the functioning of buildings' technical systems. Despite the view of technicians in the project team that in multi-story dwellings technology should be implemented which reacts as neutrally as possible to users' behaviour, users were convinced that residents' behaviour is of great significance in any case. In the users' view the technology implemented should allow for various uses without fundamentally endangering the objectives of the concept (e.g., extremely low energy requirements). For this reason it would be important for users to have a certain affinity toward the objectives of the project from the very start, for them to be selected, informed adequately and advised. For wilful forms of use can never be ruled out, as the following quotation about the winter garden illustrates:

A3: The winter garden is not generally used in line with its original purpose. Due to the great need for space, since there are no basements, the winter gardens are used for all kinds of things, as an office, as a heating room, an additional bedroom etc. A winter garden should not be used for anything which requires heating. People are already starting to put in some kind of heating, electric heating or something else. Those then are my experiences, what really happens with a good concept [which the participant himself lives in], I would say with a good project is simply that the residents just make of it what they think is the best for them.... That is my worry too, that this social housing, the passivhouse that they want to build or that is supposed to be built will naturally depend very much on the tenants whether it is a success or not, on each of them.

Wilful forms of use can, however, also arise when those responsible for planning deliberately attempt to block users' influence while at the same inadequately communicating their reasons for doing this. One participant, for example, reported how residents treated a ventilation system forced on them in a new building they had recently moved into.

B3: I have my own personal experience with that. We have a fan in the bathroom and the toilette. ... We have to have it, it's a regulation, we can't turn it off. ... I moved in and I thought, something is broken. It goes all the time. Some people have shut it down by themselves, tinkered with it. Turning it off and on, you've got to be able to influence it yourself.

Technology which cannot be influenced by its users, in this case a ventilation system working around the clock and installed by the developer in order to fulfil a guarantee, 
provokes some tenants to engage in "wilful self-help" (destruction), while causing many people to feel themselves hampered by it.

\section{Conclusion}

Only rarely are users' needs and experiences directly respected, even during the planning of innovative housing projects. Usually, architects, planners for house technology and representatives of the builder take the necessary decisions during such a building project. Users come into contact with the building and its dwellings only once construction work is already underway. The participatory model outlined here presents ways of involving experienced user groups at least intermittently in the innovation process even at an early stage.

The two focus group discussions showed that it is feasible and worthwhile to allow users to evaluate housing concepts from their point of view even at a very early phase in development. Even though neither plans, models nor photos of the planned buildings were available and these thus existed merely as narratives given by those responsible for the projects, the participants, keenly interested as they were, came to grips with the concepts relatively swiftly by means of well-targeted questions. Participants were able to name conceptual deficiencies rather quickly and to discuss suggestions for changes on the basis of their experiences. They were able to evaluate the concepts independent of personal interests, particularly since they themselves would never live in the planned buildings. The observations made during the discussions were for the most part constructive comments which could have been incorporated into the current phase of project development in an ongoing manner. Despite the plethora of results surprisingly reaped in the present case, generally it is advisable to carry out a number of focus groups (at least three) with different participants in each case.

The fact that both discussions produced an abundance of results must be attributed primarily to the participants selected in each case. Persons were intentionally selected with several years personal experience with and a special interest in environmentally friendly architecture. This procedure involved on the one hand a great deal of effort, while on the other hand it addressed residents of ecological, multi-story buildings only insufficiently.

In addition, more strongly structured moderation methods (Klebert et al., 1998) would be advantageous if focus groups are to be initiated exclusively for intervening in technological developments instead of for research purposes. Selection and evaluation results are supported by the visualisation methods constantly applied in the case of such concepts. During the entire session, results are available to all participants and also discussed in sub-groups as need arises. A further way of utilising focus groups to a greater extent for developing concrete recommendations is provided by the so-called series of focus group sessions (Dürrenberger \& Behringer, 1999, p. 24ff). In this case at least three sessions are held, all on the same topic. This procedure allows participants to acquire additional expert knowledge during the process and makes for a total of more time for developing recommendations which may be put into action immediately. 


\section{References}

Akrich, M. (1995). User representations: practices, methods and sociology. In A. Rip, T.J. Misa, J. Schot (Eds.), Managing technology in society. The approach of constructive technology assessment, pp. 167-184. London and New York.

Bijker, W. E. (1996). Democratization of Technology. Who are the Experts? Available online http://www.desk.nl/ acsi/WS/speakers/bijker2.htm

BMWV. (Ed.) (1999). Impulsprogramm Nachhaltig Wirtschaften. Konzept: Wien.

Bröchler, S. \& Simonis, G. (1998). Konturen des Konzepts einer innovationsorientierten Technikfolgenabschätzung und Technikgestaltung. TA-Datenbank-Nachrichten, 1(7), 31-40.

Catterall, M. \& Maclaran, P. (1997). Focus Group Data and Qualitative Analysis Programs: Coding the Moving Picture as Well as the Snapshots. Sociological Research Online, vol. 2, no. 1. Available online http://www.socresonline.org.uk/socresonline/ 2/1/6.html

Dienel, P. C. (1993). Die Planungszelle. Der Bürger plant seine Umwelt. Eine Alternative zur Establishment-Demokratie, Opladen

Dürrenberger, G. \& Behringer, J. (1997). Die Fokusgruppe in Theorie und Anwendung. Stuttgart.

Gibbs, A. (1997). Focus Groups. Social Research Update, 19. Available online http:// www.soc.surrey.ac.uk/sru/SRU19.html

Hofmann, J. (1997). Über Nutzerbilder in Textverarbeitungsprogrammen - Drei Fallbeispiele. In Dierkes, M. (Ed.), Technikgenese. Befunde aus einem Forschungsprogramm. Berlin. S. 71-98

Hörning, G., Keck, G., \& Lattewitz, F. (Eds.). (1999). Die gesellschaftliche Bewertung zukunftsweisender Energieszenarien - Fokusgruppen. Akademie für Technikfolgenabschätzung in Baden-Württemberg.

Jungk, R. \& Müllert, N. (1989). Zukunftswerkstätten. München.

Klebert, K., Schrader, E. \& Straub, W. (1998). Kurz-Moderation. Anwendung der Moderations-Methode in Betrieb, Schule und Hochschule, Kirche und Politik, Sozialbereich und Familie bei Besprechungen und Präsentationen.

Littig, B. \& Wallace, C. (1998). Möglichkeiten und Grenzen von Fokus-Gruppendiskussionen für die sozialwissenschaftliche Forschung. Österreichische Zeitschrift für Soziologie, 23(3), 88-102

Owen, H. (1997). Open Space Technology. A User's Guide. San Francisco

Schot, J.W. (1998). Constructive Technology Assessment comes of age. The birth of a new politics of technology. In A. Jamison (Ed.), Technology Policy Meets the Public, pp. 207-231. Aalborg.

Schot, J.W., Hoogma, R. \& Elzen, B. (1994). Strategies for shifting technological systems. The case of the automobile system. Futures, $26,1060-1076$.

Sclove, R. (1995). Democracy and Technology. New York/London.

Sperling, C. (Ed.). (1999). Nachhaltige Stadtentwicklung beginnt im Quartier. Ein Praxisund Ideenhandbuch für Stadtplaner, Baugemeinschaften, Bürgerinitiativen am Beispiel des sozial-ökologischen Modellstadtteils Freiburg-Vauban. Freiburg.

Weyer, J., Kirchner, U., Riedl, L., \& Schmidt, J. F. K. (1997). Technik, die Gesellschaft schafft. Soziale Netzwerke als Ort der Technikgenese: Berlin. 


\section{Corresponding author}

Michael Ornetzeder

Centre for Social Innovation

Koppstraße 116/11

A-1160 Vienna

Austria

E-mail: ornetzeder@zsi.at 


\title{
User-led innovations and participation processes: lessons from sustainable energy technologies
}

\author{
Michael Ornetzeder ${ }^{\mathrm{a}, *}$, Harald Rohracher ${ }^{\mathrm{b}}$ \\ ${ }^{a} Z S I$ - Centre for Social Innovation, Linke Wienzeile 246, A-1150 Vienna, Austria \\ ${ }^{\mathrm{b}}$ IFF/IFZ - Inter-University Research Centre for Technology, Work and Culture, Schlögelgasse 2, A-8010 Graz, Austria
}

\begin{abstract}
In this paper we will pose the question whether a higher level of user participation could be used as a strategy to improve the development and dissemination of sustainable energy technologies. We will especially focus on user-led innovation processes with a high involvement of individual end-users.

In our argument we will draw on several case studies in the field of renewable energy technologies - in particular solar collectors and biomass heating systems - and sustainable building technologies. Users in these case studies were involved in the design or planning processes, sometimes in a very selective way and with limited influence, sometimes very active and for quite a long period of time. Especially in the case of renewable energy technologies self-building groups were highly successful and resulted in improved and widely disseminated technologies.

Based on the empirical results of our case studies we will critically discuss the potential of user involvement (especially in selfbuilding groups) for the development and promotion of sustainable energy technologies and outline technological and social preconditions for the success of such approaches.

(C) 2004 Elsevier Ltd. All rights reserved.
\end{abstract}

Keywords: User-led innovations; Sustainable energy technology; Constructive technology assessment

\section{Introduction}

Discussion about the promotion of energy efficiency and renewable energy carriers is usually split into several compartments:

- behavioural changes, focusing on the individual consumer of energy and his/her consumption decisions, attitudes and the practices of using energy consuming devices (using CFLs, switching off devices instead of stand-by mode, etc.);

- technological change, focusing on the development and use of sustainable energy technologies (e.g.

\footnotetext{
${ }^{*}$ Corresponding author. Tel.: + 43-1-4950-442-54; fax: + 43-1-4950442-40.

E-mail addresses: ornetzeder@zsi.at (M. Ornetzeder), rohracher@
} ifz.tu-graz.ac.at (H. Rohracher). energy-efficient washing machines, biomass heating systems);

- institutional change, focusing on regulatory measures, norms, energy taxes, etc. (often addressed as 'social or institutional barriers' also).

In our paper, we will concentrate on a specific way of linking these levels and investigate a number of cases where the collaboration of users of energy technologies has not only contributed to a wider dissemination but also to technological development and product innovation. Users in our case studies have been organised within self-building and planning groups and therefore have been involved not only with behavioural questions but also with technological problems and institutional conditions. Without doubt, self-building is a strategy which will only activate a limited number of prospective users, even if there was an extraordinary diffusion success in the solar case (we will 
discuss later on, which conditions would be favourable to facilitate such an involvement). So, beyond having knockon effects on technology development, such activities should be seen as an additional element in the portfolio of strategies to introduce and improve new sustainable energy technology.

So far successful examples of user-led innovations, i.e. technologies which have even been developed or improved in user groups, have mainly been studied in the area of renewable energy technologies. A famous example is the development of wind turbines in Denmark (see Karnøe, 1996; Jørgensen and Karnøe, 1995) which was strongly influenced by local co-operatives, compared to the more science-based development of wind turbines in the US. In this paper we will complement this example with two more case studies on renewable energy technologies - thermal solar collectors and modern domestic biomass heating systems - which have also been strongly pushed by selfbuilding groups, i.e. prospective users who collectively assemble (and improve) these products. In all of these cases the strong participation of prospective users has given rise to a series of innovations leading to specific design features of these technologies that has been highly functional to a wide dissemination. Moreover, we will discuss a similar case from the construction sector: the collective planning of ecological buildings by prospective users. These examples are instructive partly because of similarities and also due to some differences. In all three cases, prospective users have cooperated in temporary groups, provided with very similar internal social structures, and in all three examples the activities are referring to energy technologies in the household sector. Moreover, the examples cover planned (sustainable buildings) and unplanned (solar collectors) processes as well as examples from different geographical regions.

The interesting questions for us are: Is it possible to transfer the experiences and success stories from the sector of renewable technologies to energy-efficiency technologies? Under which conditions and in which cases could such a direct form of user involvement work? How could a higher participation of users be promoted in certain areas of technology development? Although the question of transferring experiences with self-building from renewables to energy efficiency technologies may be somewhat speculative, we will present some ideas on technologies or applications where such an approach might also work. In particular, we will focus on a hypothetical example for possible user involvement by self-building activitiesthe development and improvement of 'smart home' applications devoted to energy efficiency. Based on this example we will finally discuss some options of selfbuilding as a strategy to support innovation processes in general.
To get the message clear: what we are aiming for is not a plea for an unconditional support of self-building groups as a way to develop and introduce sustainable energy technologies. We rather want to point out that under certain conditions a higher degree of user involvement or self-building groups might lead to a successful mode of innovation which has often been neglected and which could contribute to the design and diffusion of certain energy technologies.

\section{The role of users in innovation processes}

Let us first start with some general remarks on the role of users in innovation processes. Contributions from the field of social studies of technology have emphasised the importance of users in technology development. Users ${ }^{1}$ or future users of technology are seen as an important source of innovation (see e.g. Von Hippel, 1988). In many cases technical improvements are realised during the diffusion phase by user feedback or re-invention by users (see Rogers, 1995). Our case studies of user-led innovations show how the users can be involved in the design and dissemination of technologies at different levels of intensity. Early users can start off completely new technologies and designs (e.g. a specific type of self-built solar collector). They can find and test new applications of a product (such as solar space heating). They can be the source of incremental technical changes (like the control system or additional security components in biomass heating systems) or they can appropriate unconventional building technologies and design solutions in the course of collective planning processes.

However, as the analysis of literature on technological innovation and users reveals, the role of users in innovation processes is much broader than the focus on self-building groups (i.e. user groups who assemble and implement specific technologies on their own, as will be pointed out in the case studies) and direct user participation might suggest. Even without active user engagement, practices of use and images of users shape the design of technologies and products: through the imagination of designers about future uses and users, through the experiences of designers or producers as users $^{2}$, or through various techniques to represent the

${ }^{1}$ It should be mentioned that the term user is rather ambiguous. In innovation studies users are very often firms or organisations (with respect to certain products, they can be producers of other goods). Moreover there is a range of intermediate users, e.g. doctors in hospitals who may be addressed as 'users' of drugs or other products by pharmaceutical companies, although the end-user is the patient. In this paper we mainly refer to individual end-users of energy-efficient technologies in households.

${ }^{2}$ As it turns out it is not so rarely the case that designers of products are at the same time users, sometimes their own first users (see Akrich (1995), or for the case of sustainable buildings Rohracher and Ornetzeder (2002)). 
needs and expectations of future users and match it with the design of a product. Moreover, users actively appropriate products and technologies without being directly involved in the design process: ${ }^{3}$ by using technologies in a specific way or by attaching particular meanings to technologies and integrating them in a 'cultural universe'. Users may also try to change or redesign technologies, or block their usage (as sometimes experienced with ventilation systems in sustainable buildings).

During the design and dissemination of a technology, designers and users are linked to each other through a number of processes and relations:

- both sides refer to certain discourses (e.g. of sustainability, modernity), which at the same time restrain their 'room for manoeuvring' and orient their expectations and actions;

- technologies are part of wider sociotechnical regimes and sociotechnical landscapes (Rip and Kemp, 1998) which also include joint expectations, social practices and institutions (norms) and thus also relate technology design and use;

- intermediate actors (such as energy agencies or consumer associations) translate and mediate between the interests of producers and users.

Seen from this perspective users can be conceptually located within a field of tension-of passively being configured by other actors and of actively appropriating technologies (see Shove, 2003).

Beyond the observation that users in the widest sense always play a role in technological innovations (because products are always culturally appropriated), we also have to ask about the quality of the mediations between design and use. Generally these mediations can be understood as social learning processes between the various actors involved in the development, distribution and adoption of technologies, which may lead to a better match of design features and practices of usage and are crucial for the successful dissemination of technologies. However, these learning processes often happen in a non-systematic and barely reflected way, and in many cases do not make sufficient use of the available potential of user experiences and expectations for further product improvements.

This is the stage where self-building activities, as described in the case studies, enter the picture. User participation may be one tool (under certain conditions) which may help to improve such learning processes. In a way self-building activities are one of the extreme poles of the range of possibilities for user involvement and activities: users develop (or at least assemble) technol-

${ }^{3}$ For a discussion of the appropriation of technologies, see e.g. Lie and Sørensen (1996), or Mackay and Gillespie (1992). ogies on their own. As our cases show, even within these self-building activities, various levels of user involvement can be found. Participation ranges from bottomup initiatives with a largely independent design of technologies and establishment of organisational structures to more top-down oriented approaches, where groups are centrally organised by an existing organisation and products are mainly assembled from prefabricated components. Beyond such do-it-yourself approaches there are also less intensive ways of user participation, such as 'stakeholder workshops' in the early phase of product design (as suggested by the approach of Constructive Technology Assessment, e.g. Schot, 2001), or the selection of a small number of interested and innovation-oriented users to jointly improve product specifications, as attempted in the lead-user method (e.g. Herstatt and Von Hippel, 1992).

\section{Successful examples of user-led innovations: three case studies}

In this section, we will set out to study some examples of the collective self-building of technologies and participative planning processes, as a possible way to develop more appropriate technologies and enhance dissemination. The first two cases are renewable energy technologies, while the third one is an example from the planning of green buildings. In light of the characteristics of such examples, we will make some (limited) generalisations in the following section and ask for preconditions of a higher user participation in technology development and the chances to transfer such results to the area of energy efficiency.

\subsection{Thermal solar collectors}

In Europe, solar water heaters were not adopted until the 1973 OPEC oil embargo. From 1973 to 1978, the development of solar technology was influenced mainly by research activities and funds from public institutions and industrial companies. A first slight boom took place on the Austrian market for solar water heaters from 1979 to 1981 , mainly caused by the second oil crisis, increasing private demand and the market penetration by large-scale companies. This boom came to a sudden end in the early 1980s, due to the stabilisation of the oil price, and problems with the technical reliability of installed systems. However in 1987, a second boom started and it is still active. In the second half of the 1990 s more than $150,000 \mathrm{~m}^{2}$ collector surface per year was installed in Austria (Faninger, 2000). Due to this mature domestic market, Austria's solar industry was able to take a pioneering role in Europe. Today the export share of solar collectors exceeds the domestic share. According to a recently published report, Austria 
leads the European per capita solar statistics with an installed collector area of approximately $290 \mathrm{~m}^{2}$ per 1000 inhabitants by the end of 2001 (Fink, 2002). Also considering the annual growth rates, Austria is situated in the first position, with Greece, Denmark, Switzerland, and Germany following (Stryi-Hipp, 2000). By the end of 2001 , more than $1.700000 \mathrm{~m}^{2}$ of flat plate collector surface were installed in Austria. At present, approximately $15 \%$ of all private single-family houses are producing hot water by means of solar heaters (Faninger, 2000). Interestingly, this extremely successful dissemination rate is partly due to the fact that more than $400,000 \mathrm{~m}^{2}$ collector surfaces were manufactured in privately organised do-it-yourself groups (Fink, 2002). Approximately, 40,000 solar heaters are equipped with self-built collectors in Austria.

The user initiative which set off this development first, started in the early 1980s, even at a time when the topic of solar energy was no longer in the focus of the public debate. Two skilled Styrian amateur inventors, a fruit farmer and a technical engineer, were fascinated with thermal solar technology. Together with some friends, they developed a simple self-build method adapted to the needs and abilities of the rural population aside from the commercial market for solar heaters. The first selfbuild group with 32 participants was established in a small village near the city of Graz in 1983 . The idea to practice do-it-yourself methods in groups and not individually was mainly based on a local tradition. This rural part of Austria, Eastern Styria, is well-known for its wine and fruits. People of this countryside are used to cooperating at least during harvest season. Even in a technical world, apples of high quality have to be picked manually. Thus, once a year, all available family members, friends and neighbours work together for a short time. Thus, if one were to know how to organise and motivate an informal working group it would be easy to transfer this social pattern of cooperation to other purposes.

The positive experiences of constructing solar collectors in self-building groups of prospective users of these collectors were soon spread by word of mouth and fuelled neighbouring communities' interest to start similar groups that tapped the sun's energy. Before the end of 1984, the enormous local demand for solar collectors required the establishment of two more selfbuilding groups, each with more than 100 participants. When more requests were made from other parts of eastern Styria, some of the more active knowhow carriers decided to hold a series of evening lectures in order to report on the solar system self-build method.

In 1986 and in the following years, the Styrian selfbuilders based only in a small region were able to produce more solar collector surface area than all commercial suppliers in Austria put together (see Fig. 1). In order to meet the ever increasing demand in 1987, the first solar system build-it-yourself guide was produced. Training seminars were organised for construction group leaders and other interested persons who wanted to familiarise themselves with the method of solar system self-building. To improve communication, a news bulletin titled 'solar info' was established. An important step in this process was the institutionalisation of the self-build movement. The Association for Renewable Energy (AEE) was founded in June 1988. The AEE was awarded several environmental and research prizes, which brought them additional recognition. As an official representative of the solar system self-build movement, the AEE was able to receive public funds support. This enabled the AEE to do their work on both a broader and more stable basis. After a few years, the AEE expanded throughout Austria by establishing regional divisions. The self-build method also found followers in neighbouring countries such as Switzerland, the Czech and Slovak Republics, and Slovenia. The AEE became, meanwhile, one of the most important know-how carriers not only in the field of thermal solar energy but also in regard to other renewables in Austria. For the sixth time in the year 2002, the AEE has organised an international symposium on thermal and photovoltaic use of solar energy.

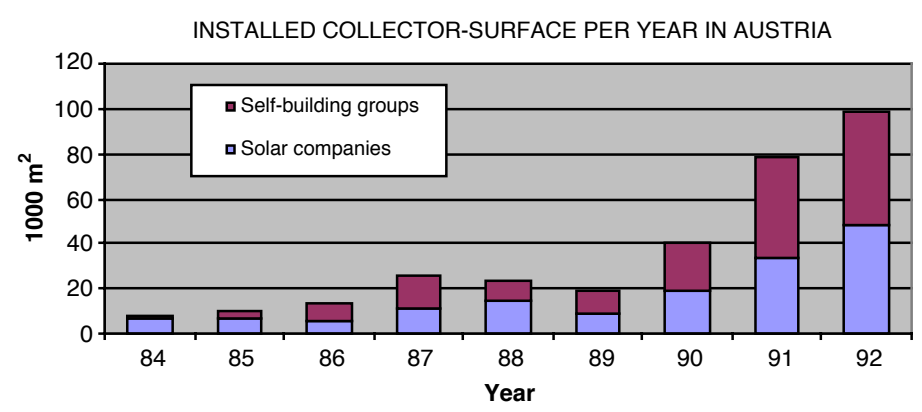

Fig. 1. Market share of self-building groups and companies in Austria. Annually installed collector-surface from 1984 to 1992. 
The AEE's latest step toward professionalisation was the establishment of a planning office in 1993.

The production of self-built solar systems was mainly organised in autonomous groups with participants between 10 and 100 . The foundation of a new group started, in most cases, with an introductory lecture and an excursion to existing self-built solar systems. Former group leaders or members of the AEE then offered individual technical advice and guided the work within the new group. These activities were of prime importance for the second boom on the Austrian solar market at the end of the 1980s. In detail the main steps of the applied strategy could be described as follows:

1. Introductory lectures: First, independent community lectures concerning the use of solar energy and the methods of self-building are presented. The organisation of these lectures occurs mainly through resident people interested in solar systems. By using local organisations to arrange the lectures, the scepticism toward the unknown is largely reduced, resulting in more interest. These lectures bring the subject 'renewable energy' to the people and present them with a possibility for action. For more than half of the self-builders, such a lecture is the first contact with the topic of renewables.

2. Visits to installations: If people are interested in building their own solar system, they are usually invited to both join an excursion to one of the existing self-built solar systems and to talk to the users about their experiences. The possibility to prove the performance of this technology is a crucial point within the whole decision process. Specifically, it helps to reduce uncertainty about this technological innovation.

3. Sizing the system: In the course of a further meeting, a member of the AEE calculates the size of the system, explains the connections to the existing heating and hot water system and gives advice about optimal integration. This service is necessary due to the uniqueness of every household. The calculation also helps to reduce existing uncertainties about the compatibility of solar systems.

4. Formation of self-building groups: If participants agree to form a self-build group, a few people become responsible for the coordination and organisation of their group. These group leaders are provided with technical and organisational know-how at weekend seminars offered by the AEE. Every self-build group is a financially independent organisation, which decides alone where the necessary materials should be purchased. This collective purchasing enables very low prices.

5. Construction phase: The absorbers are manufactured collectively. The necessary tools such as presses, bending and soldering jigs are made available to the groups by the AEE. Teamwork also enables people with less technical experience to take part. Only after all the necessary absorbers have been produced, they are distributed among the group members.

6. Dissolution of the groups: The average life of such a construction group is approximately three to four months. While the assembly and installation work is either done by the group members themselves or with the assistance of local installers, it is recommended by the AEE that groups should arrange for 'neighbourhood teams' already during the construction stage in order to facilitate installation by the group.

In addition to the enormous dissemination success of this strategy, the activities in a large number of selfbuilding groups led to some important technical optimisations stimulated by user experiences and user feedback. From 1986 onwards, the self-build group leaders met on a monthly basis to discuss the advantages and drawbacks of different types of systems. During that period, the technical system underwent a number of important improvements based upon practical feedback of former participants and technical skills of new group members. For instance, the piping of the absorber was no longer soldered at every bend but produced from a single piece of copper tube. For this purpose, a special tube-fitting table was developed. At the same time, the device used for soldering sheets and piping was considerably improved. Over the years these special tools developed into a complete 'tool kit' that was rented to new groups against payment of a small fee. These technical innovations brought about not only manufacturing advantages but, by making soldering spots redundant, also a reduction to the finished system's susceptibility to break down. A further improvement was achieved with regard to the collector housing, which for anti-corrosion purposes was no longer made of zinc-lined steel sheet but of high-grade steel. As in 1986, the first collectors that could be directly integrated into the house roof-provided that the tilt and orientation were suitable- became available. This installation method - at that time exclusively used by self-builders - made it possible to cut financial expenses by avoiding the need for steel housing and, in many cases, it provided an aesthetic solution which encouraged the dissemination of solar systems considerably.

In the mid-1980s, users of self-built solar systems began to use existing hot water systems for spaceheating also. Because of a lack of commercial examples, those activities were rather innovative. Most of the experiments started quite simple. Some of the self-built solar systems produced more heat than the households were able to consume, so some users adapted the existing systems in order to heat the bathroom (a room where higher temperatures are welcomed even in 
warmer seasons). Based on these first experienceswhich were quite encouraging - space-heating became an intensively discussed issue in the group leaders meetings. Shortly after these discussions, the first hot water and space-heating designed systems were realised in some self-built groups. Starting from very limited heating capacities, the self-builders have developed an economically optimised type of solar combisystem working as an ecological backup of the existing heating system. Solar heating with such combisystems was also very important for the dissemination success of solar systems in general. Today, approximately, every second new installed solar system in Austria is realised as such a combisystem.

In this respect, the self-build movement could also be seen as a large decentralised 'development division' for solar heating systems, in which over many years a great number of practice-relevant technical improvements and new forms of applications were compiled and realised. A great number of users all over Austria were and still are in contact with the AEE. Within this network of qualified users, positive and negative experiences with the technology are communicated. As a result of selfbuilding these users are very 'close' to the technology and some of them have been directly involved in the improvement of the technical system. As historical studies of technology show, such a dispersed development and collective improvement of technologies can especially be found in early phases of product development - an example is early user clubs in the development of the personal computer.

Many of these improvements have been adopted by commercial producers and installation companies (e.g. a special glass cover sealing, using parts of available glasshouse systems; roof-integrated collectors; solar systems for space heating), which currently operate as very professional and successful enterprises. In Austria, commercial solar systems are of good quality and prices are much lower than ten years ago. Contrary to the misgivings of solar companies, the success of the self-build movement had positive effects on their sales as well. The further development of the solar market had an increasing dynamic by a "selfenforcing process". A growing number of solar collectors made it easier for potential adopters to visit existing devices. More information about this new technology was spread. It was more likely to have a friend or acquaintance who already had a solar heating system. In recent years solar companies have been extremely successful in Austria, partly because of this specific precondition.

\subsection{Biomass heating systems}

The second case we want to turn to are domestic biomass heating systems. In 1998 biomass contributed with $125 \mathrm{PJ}$ or $10.5 \%$ to the total primary energy use in Austria. Accounting for more than $57 \%$ of the biomass used for energy purposes, fuel wood is the main source of biofuel in Austria. Fuel wood still is an important energy carrier for domestic heating in rural areas (between a third and a fifth of all households), due to the high proportion of forests in Austria. However, although these figures seem quite impressive (and are among the highest proportions of bioenergy in Europe), they conceal a lot of problems for the future development of renewables in domestic heating. As mentioned above, much of the high proportion of renewables in Austria is due to the use of wood-a traditional energy carrier that rather is on the decline and not a signifier of a new move to renewables. The main strategy chosen to sustain the high level of fuel wood use has been to develop new heating systems. ${ }^{4}$ Major steps have been made in the past 15 or 20 years to improve the technological standard of domestic heating with biomass. Today domestic biomass heating systems have hardly anything in common with traditional woodstoves, which are still widespread in Austria. Modern biomass boilers are used as central heating systems and are highly specialised in certain kinds of woodfuel. The main types are woodchip boilers, which operate (fully) automatically over the whole heating season, but meanwhile boilers for pellets (pressed from saw dust) are growing in importance, especially outside the agricultural sector.

In the period of the early development of modern biomass boilers, self-building groups have been organised between 1985 and 1989 by two organisations: the Association for Regional Development (OAR) and the Chamber of Agriculture. Compared to solar collectors, the self-building activities were more centrally organised. One motivation was that activists who had been engaged in building solar collectors were looking for additional opportunities to develop and install sustainable technologies. Together with OAR they developed a technical concept for woodchip boilers, which were commercially available at that time but of rather bad quality and low efficiency. As the organisers of these groups pointed out in articles, the advantages of such self-building groups were:

- the jointly organised purchase of materials and mechanical components;

- lower prices because of large quantities of components;

- low-cost production due to DIY (price-cuts could range from $25 \%$ to $50 \%$ );

- mutual support in group work;

${ }^{4}$ For an analysis of the development and introduction of this technology from a sociotechnical perspective, see Rohracher (2002b). 
- high reliability of heating system because of well-tried design;

- everybody knew his/her system and would be able to repair it;

- experience of collective work and support.

All in all, between 10 and 15 such groups with 10-12 participants each were established. This does not sound an awful lot, but given that at that time about 170 boilers were purchased in Styria (1.2 million inhabitants), an additional number of 12 new boilers in a village were quite significant and newsworthy. We will not look in detail at the organisation of the groups but focus on some technical changes which came out of these activities.

Two main, rather incremental, technical changes first appeared in self-built biomass boilers before they became a standard feature of commercial boilers (though there is no hard evidence that the commercial sector adopted these ideas and did not develop it independently). The one change was a much more advanced safety system to prevent an inflammation of the stored woodchips through 'back burning' from the combustion chamber. Safety was a prominent and permanent topic in the discussions of the self-building groups and everyone wished to have the highest possible protection. Downspouts and fire sprinklers were installed between storage and the boiler and photosensors controlled sensitive places to prevent back-burning. The second innovation was an electronic control system, which was much smaller, more flexible, 'intelligent' and comfortable than the electro-mechanic systems that existed at that time. Not only were the safety devices integrated in the control system, but the user interface also allowed to set temperatures in advance etc. The two areas of innovation thus were safety and comfort - two issues that are high on the agenda of users but apparently were not sufficiently taken into account by early boiler manufacturers.

However, as it also turned out, the construction type of self-built boilers (which was one of two main types of construction available at that time), which was primarily determined by the wish to be able to easily integrate these boilers into existing systems (and even using parts of the existing boiler) turned out to be a technical deadend for a number of reasons. The design that finally was adopted by commercial producers was much more difficult to produce in self-building groups. ${ }^{5}$ Although participants were highly content with their work in the groups and the product they produced, self-building was

\footnotetext{
${ }^{5}$ One possible way out of this problem, as one of the group organisers suggested, would have been to increase the degree of prefabrication (in collaboration with a producer company) and mainly assemble the boiler.
}

stopped because OAR did not get further finance for their co-ordination and organisational work and because organisers had the feeling that commercial boilers were of sufficient quality meanwhile.

\subsection{Sustainable buildings}

In contrast to the technology-centred case studies on solar collectors and biomass heating systems, the third case study is from the field of sustainable buildings. The focus in this example is more on collective planning of ecological buildings, but due to very similar organisational structures a comparison offers some additional insights in participative design and planning processes. The case study concentrates on co-building groups in the German city of Freiburg which have been active in the development of a new sustainable residential area (Sperling, 1999).

In the South of Freiburg, on the former area of a French barracks site, the new 'Vauban' residential area is being developed for 5000 inhabitants. The planning process started in 1993 and in 2006, after three development sections, the district will be completed. In spring 1995, the City of Freiburg initiated a process of citizen participation, based on the experiences in another development project, the 'Rieselfeld'. Because of unsatisfying results of this first participation process the private association Forum Vauban e.V. was established and was accepted by the city to be the organising body of the participatory process in Vauban. The city gave some core funding to Forum Vauban which enabled it to establish citizen participation on a professional basis.

From the very beginning, Forum Vauban did not want to restrict itself to merely organising and coordinating, but developed suggestions for the planning of the district. Therefore, Forum Vauban got additional funding of the German Environmental Foundation. Experts developed a set of measures for a 'sustainable model city district Vauban', dealing with the fields of traffic, building, energy, nature in the city, sanitation and public space. The results of this study were discussed with citizens and finally presented to representatives of the city. Many of these suggestions became part of the official planning objectives, others were implemented later on by private initiative in parts of Vauban.

Another issue at that time was to get in contact with future inhabitants of Vauban. For that purpose, Forum Vauban and the city council jointly ran a publicity campaign with special regard to ecological and social city planning in 1996. After this campaign, Forum Vauban organised information fairs and encouraged interested people to form co-building groups.

Key dates of the sustainable model city district Vauban (Forum Vauban, 2002): 
1993 start of the project on December 14th

1995 start of the participation process: Forum Vauban e.V. is recognised as legal body of the extended participation process and is funded by the city

1996 main discussions about the master plan, Forum Vauban influences the planning based on the results of research project and discussions with citizens, large publicity campaign mobilising the first future inhabitants, formation of the first cobuilding groups, Freiburg-Vauban is a German Best Practice at the Habitat II conference in Istanbul, bimonthly district newspaper 'Vauban actuel'

1997 concepts are taking shape: EU-LIFEproject supports the implementation of sustainability concepts in the fields of mobility, energy and social/ecological building, the first building lots become available for co-building groups, cooperative building initiatives, private builders and a limited number of commercial builders

1998 start of construction (1. phase), 140 out of 450 units are organised in co-building groups

2000 'turning point' of the Forum's work: completion of the EU-LIFE-project, conceptual and scientific work is completed and documented, the new focus is on social work (communication with all new inhabitants and the development of neighbourhoods)

2001 start of the second construction phase, 30 co-building groups with around 300 participants

2002 many people move into the second sector, start of the neighbourhood centre, more than 2700 people are living in Vauban

2006 official end of the project by December 31 st, all building lots will be sold and the residential area will be completed

The organisational structure of the above mentioned co-building groups is of special importance for our discussion. Forum Vauban favoured this form of building from the beginning because it promised the best combination of both participation and individual planning on the one hand and the realisation of the ambitious aims of the sustainable model city on the other hand.

Co-building means that future inhabitants organise themselves within groups of 5-15 families in order to plan and build a house together. In most cases, these groups were formed around existing social relations, starting with similar visions for the new house and looking for additional group members. Having reached the appropriate size the group is bound together by contracts, acquires a building ground, assigns an architect, plans the building in cooperation with the architect and other planners, and finally commissions a construction company to realise the project.

Co-building in that form is not so rare in the field of ecological housing (Gestring et al., 1997). However, in Vauban the different groups were integrated in a network by a special coordination structure and the Forum Vauban provided consulting services throughout the whole process. Representatives of each group met on a monthly basis to discuss technical questions, share their experiences and problems, and to support each other. These meetings - organised by Forum Vauban staff members - made not only the coordination between the different groups possible but also allowed to prepare information material important for all groups. In different stages of the planning process Forum Vauban organised information fairs, individual consultations, or excursions to existing eco-villages. Moreover, Forum Vauban was able to influence the individual planning, in order to meet the ecological requirements, and to represent all co-building groups in negotiations with the city or construction companies.

Within the first and second construction phase 45 cobuilding groups were formed with around 450 members (families). That means that nearly one-third of all flats in Vauban were realised by co-building groups. Within these groups, the future inhabitants were able to build individually but also very cost-effective. Moreover, the new neighbourhoods began to grow at a very early stage. Many co-building groups have realised themselves special ecological and social measures within their new homes beyond the official planning which already includes for example low energy building, public transport and keeping cars outside the district. Most individuals were intensely involved in the planning process which resulted in high identification with most of the technological decisions. Therefore, the special type of co-building in Vauban provided an unusual basis for technical innovation. Most of the co-building groups were encouraged by this structure to realize very innovative building concepts with new and unusual technologies (e.g. vacuum toilets in combination with a collective biogas system). The user experiences with such technologies will be very important for the further development and dissemination. 


\section{User participation and energy-efficient technologies}

\subsection{Lessons from the case studies}

Our case studies highlight the role of users in innovation processes under specific social conditions. As we could see, most users were involved in cooperative production or planning processes. As a result of selfbuilding and planning in groups, these users started to modify and improve the technology, and sometimes even completely new technical options came up. Selfbuilding groups accelerated the dissemination, participative planning promoted the adoption of novel and sometimes risky technology. All forms of participation are linked with social learning processes. In detail the reported examples resulted in several positive effects such as:

- Technical innovations: Within solar and biomass selfbuilt groups a wide range of technical innovations and incremental improvements have been developed (e.g. special type of self-built collector, roof-integrated collector, solar combisystem for space-heating, electronic control system and advanced safety system for biomass heaters). Some of these innovations have been adopted by commercial producers and installation companies later on.

- Dissemination of technology: Especially in the case of solar collectors self-built groups have stimulated the diffusion of the technology considerably. In Austria approximately 40,000 households are equipped with self-built solar collectors. Reasons for this successful dissemination are low-investment costs due to bulk purchases and personal contribution, personal advertising by company-neutral users (lectures and excursions), social motives to join a group in the neighbourhood, relative advantages of solar systems in rural regions (added comfort).

- Social embedding of unconventional sustainable technology: Users organised in co-building groups deliberately decided to adopt very innovative and partly risky technologies (e.g. vacuum toilets in combination with biogas systems in the city district Vauban) and to realise novel building-concepts (e.g. ecologically optimised passive houses). The resulting user experiences with those technologies are of major importance for further technical improvements.

How can we explain this success? Of course, there are many reasons and most of them have been already discussed in the examples. But from a more general perspective, a specific form of social organisation seems to be particularly important in this respect: autonomous social groups embedded in a wider social network and linked together by a coordinating structure.

In all case studies, users are organised within temporary social groups aiming at a common purpose.
People with different professional backgrounds, skills, and different experiences come together and share these abilities. In contrast to individualised forms of DIY, people in our cases organise groups in order to benefit from each other. The cooperation is mainly based on mutual trust, therefore it is helpful to form groups around existing social relations. Trust also ensures that innovation-relevant information is freely disclosed and assistance is given for free. As we know from small group research, the effectiveness of groups regarding specific tasks (like searching, defining, or judging) is much higher compared to the individual performance of all group members (Hofstätter, 1986). Interaction and mutual completion in groups are primarily responsible for that effect. In many cases groups therefore help to avoid shortcomings. These general characteristics of small groups are effective in the studied examples as well. The temporary technology-centred group creates a stimulating learning space and is a potential source of technical innovation.

In spite of these positive effects of group organization, the influence of single self-built groups on the technical development would have been very limited without a more stable coordinating structure. In the solar case such a structure was developed by some active group leaders (later on institutionalised as an association), in the biomass case and in Freiburg-Vauban existing organisations took over this networking activity. The coordinating structure is able to organise the communication between different user groups and links the activities to a wider network of relevant social actors, such as manufacturers, suppliers, professional planners, funding agencies, etc. Such a stable organisational unit enables long-term learning processes between different user groups and between users and professional producers. It is possible to collect all the different ideas and experiences from several groups, to assess and select them, and make them available to new building groups and other interested social actors.

Our investigation of self-building (and planning) groups for renewable energy technologies also gave some evidence of a number of preconditions and success factors of technology development with high user participation. The following paragraphs give a preliminary list of supposed restrictions and conditions for such a mode of product development:

- Technical characteristics: Even the differences between the self-building experiences of solar collectors and biomass boilers reveal that technical characteristics may have a strong influence on the chances of such a kind of user involvement. Technologies appear to be appropriate for self-building, if they are technically not too complex (e.g. the present construction of biomass boilers appeared not to be feasible for self-building) and if they do not need highly specialised and expensive tools to fabricate, or 
if a high level of technical competence is required. However, there are ways of dealing with such a situation, like increasing the degree of pre-fabrication of components and closer collaboration with producer companies.

- Lifecycle of the products: Apparently the chances of successful self-building are much higher in the early phases of technology development and dissemination. At this stage it is easier to develop solutions which are superior to (often immature) commercial products. Moreover, potential cost benefits of self-building are higher as long as commercial products are sold in low numbers and cannot sufficiently profit from scale benefits. As soon as cheaper and technically more mature products are offered in the market, selfbuilding activities are often on the decline (e.g. in both of our cases, solar and biomass).

- Specific motivation of users: A specific and high motivation of users is needed to invest sufficient amounts of time and energy into the work of selfbuilding groups. Beside cost reductions (which are an important driver, indeed), issues like 'environmental protection', 'regional development', 'energy saving' or 'using ecological and healthy materials' played an important role. In this way, work in a self-building group can be linked to a mission and can be tied up with broader social aims. Especially organisers and coordinators of such groups, who do not profit from building a second heating system, need such a kind of orientation and legitimisation. A specific case of motivation are hobbies, where self-building is not uncommon (e.g. building boats or gliders from prefabricated parts or with support of manuals).

- Specific socio-cultural milieu: An interesting point is the probable dependence of self-building activities of certain socio-cultural contexts. In the case of solar collectors and biomass boilers, the rural setting already had a tradition of neighbourly help or of jointly using and purchasing expensive tools and machinery in the agricultural sector. In regions and environments, where such traditions do not exist (and this was even the case in smaller cities in these regions), self-building activities appear to have less chances of success. However, the example of Freiburg-Vauban shows that under certain conditions self-organised planning of green buildings may also be successful in cities.

Moreover, such drivers and conditions are traded off with other investments (e.g. time budget needed) and alternative possibilities (e.g. purchasing a modern gas boiler instead of biomass heating) and their performance, price, etc. In our cases, the above-mentioned conditions were either satisfied or participants were restricted to small groups, for whom the self-built product was especially attractive (e.g. for farmers with small forests and own wood residues).

As we can conclude from these case studies, strong forms of user involvement, like self-building of technologies, indeed depend on a number of preconditions. Hence, we must ask: Could such a mode of innovation and dissemination also work for energy-efficiency technologies or a larger number of sustainable energy technologies in general? Or does it only work in a very limited number of cases mainly with renewable energy generation? A number of examples from other technological fields at least support the case that cooperative forms of self-building are quite common. In some prominent cases users did even play a decisive role in early phases of the technical development. Technologies like the personal computer (Allerbeck and Hoag, 1989), open-source software (Von Hippel, 2001a), or sportsrelated consumer products (Franke and Shah, 2003) have been mainly developed by users participating in community-based networks.

Thus, there are good reasons to believe that selfbuilding as an innovation strategy could well be extended to other technologies, for instance to the area of 'energy saving', which at least provides a specific motivation. As the example of Freiburg-Vauban shows, such experiments can work for planning processes of sustainable buildings and the widespread tradition (at least in some countries) of taking part in the building of ones own (usually single-family) house and DIY indicates that energy-efficient construction certainly may be an issue for prospective users of buildings. As we have mentioned earlier, self-building of products is at the extreme end of user involvement and successful participation of users could also work in 'weaker' variations. To get a more concrete picture of such possibilities we will shortly sketch a hypothetical example of a technology related to energy efficiency where more participation of users might help to improve certain applications and support their dissemination: smart home applications to improve energy efficiency.

\subsection{Hypothetical example: smart home technologies for energy efficiency}

Let us give a very rough introduction to this set of technologies. The main characteristic of 'smart homes' is a communication infrastructure, which connects various sensors, appliances, and devices (lighting, heating and ventilation, security systems, household appliances) within the building and often to external networks such as the Internet. Currently, there is a strong push towards these technologies coming from producers and also from building societies, developers, etc. One of the standard arguments for the use and promotion of these technologies is their contribution to energy and, generally, resource efficiency. 
Indeed there are a number of applications which could contribute to sustainability in buildings:

- energy management, i.e. better control and integration of domestic service facilities, such as switching off ventilation and heating when windows are open; separate and programmable temperature control for all rooms; central switch for all power consumers when leaving the house;

- feedback on energy consumption of the building or certain appliances via the Internet;

- load management and other new services provided by, e.g. utilities via power lines;

- intranet solutions in blocks of flats to provide services such as car sharing.

However, given the broad field of possible applications of smart home technologies (e.g. as security devices, for entertainment or convenience), people will not necessarily make use of the resource saving potentials of IT in buildings, but may on the contrary even contribute to additional electricity consumption through further electrification of households and higher standby energy losses. The environmental effectiveness of such technologies thus depends on the practices that develop around it in the course of dissemination and the way the technology is adapted to these new requirements.

In-depth interviews with early users of smart homes in Austria ${ }^{6}$ indeed revealed some similar preconditions than the ones enumerated above for self-building groups. Especially those users of smart home technologies who had a large number of specific applications were especially motivated to improve certain applications, find even new ones and tinker with this technology. Among intensive smart home users, a majority of respondents had a technical vocational background on their own (as electricians or in the IT sector) and interestingly placed considerable emphasis on energy issues. Some of them even had figured out sophisticated control algorithms on their own-e.g. a warm water circulation pump (to immediately get warm water even if the central water heater is at some distance) connected to an occupancy sensor in the bathroom. The pump then only worked for two minutes and the sensor did not react again for the next fifty minutes since the user had discovered that the water stayed warm in the pipes for this time. At the same time, many of these users complained that smart home technologies would increase their dependence on electricians - they were not even able to install a new lamp on their own or change settings of the system without special knowledge.

It is certainly a speculation whether certain kinds of user involvement could be successful for such a technology, but there are a number of points of

\footnotetext{
${ }^{6}$ For more details see Rohracher (2002a).
}

departure to organise activities such as user clubs to develop applications, which are more apt for users than the ones offered presently (which are seen as rather useless by many potential users). On the one hand, user activities, like the one example on circulation pumps, could be supported or organised by, e.g. energy efficiency organisations. On the other hand producers of smart home technologies could develop tools (and some efforts are being made in this direction) which would allow a deeper engagement in designing one's own applications. The interesting question certainly would be whether it is possible to organise and link such user experiences in a way that social learning processes are possible and these activities are also oriented towards broader aims such as energy efficiency.

\section{Methods to promote user-involvement}

Our example on smart home technology should illustrate that there are realistic applications for selfbuilding activities related to energy efficiency. Of course, we have no guarantee that organised self-building would really work in that specific case, but there are some strong arguments which suggest to implement such a strategy to support the development of energy-efficient technologies by direct user feedback. Moreover, organised self-building could be useful for innovation processes in general. Taken into account that classical forms of DIY are very popular in the field of end-user technology we could assume a considerable theoretical potential for self-building groups.

As we discussed earlier in this paper, organised selfbuilding is transferable to other technologies and social contexts under specific conditions. Therefore it is very important that a specific technology is in an early phase of development and dissemination. In this phase there is a higher chance that users come up with new or superior technical solutions. Because of high production costs during the early phase of product dissemination, selfbuilding in many cases is economically attractive, too. The technology itself should provide some space for DIY activities. Specific tasks should not be too complex and feasible without the need for specialised tools and high levels of technical competence. In order to extend self-building to more complex technology, professional manufacturers could provide special user toolkits which allow to transfer more design capability to users (for similar suggestions for non-energy technologies see e.g. Von Hippel, 2001b).

In order to implement self-building as an additional innovation strategy it could be helpful to build on new approaches in the field of technology assessment (TA), in particular 'Constructive Technology Assessment' (Schot, 2001) and 'innovation-oriented TA' (Bröchler and Simonis, 1998), which have been developed in recent 
years. Such approaches no longer concentrate on the evaluation of new technologies, but rather focus on the processes by which technologies arise and, beyond this, attribute a significant role to the potential users of such technologies. Broadening the design process in such a way means that possible problems in the contexts of 'real-world use' can be recognised at an earlier stage and can be minimised by making appropriate changes. Technology assessment thus becomes an increasingly participatory process, systematically nurtured not only by scientific know-how but also by the everyday experiences of technology users.

Applying such an approach to the development of sustainable energy technologies would mean that research institutes and producers have to agree to establish an institutionalised know-how exchange with experienced users. Producers should provide latest technology and/or special construction kits to a selected group of users. The whole participation process could be organised by existing TA-institutes or similar organisations. In order to start up stable learning processes it is of crucial importance to find social niches with highly motivated users, to organise communication among them, and to link user experiences to producers and research units. Experienced users will be interested to contribute in such processes only if they profit personally from the involvement, e.g. by cost reductions or free technical support, and if they are motivated by specific goals associated with the technology, e.g. energy saving. Smart home technology is insofar a relevant example as the products available on the market are in an early stage of development and dissemination and the investment costs are relatively high. There is certainly a potential for energy saving in the household using smart technologies but realistic applications are still missing. As our hypothetical example shows, users are able to come up with such realistic forms of use mainly because they are directly confronted with specific problems and technical conditions.

In any case, the success of planned user involvement will be essentially supported by a social structure consisting of autonomous self-building groups which are connected to similar groups and other relevant institutions within a wider social network. If selected users are addressed not only as users of a specific technology but also as producers or planners (even if this part is rather small), behavioural, technical, and institutional aspects of energy consumption will be integrated and new ways of thinking about new technological options could arise.

\section{Acknowledgements}

We are grateful to the 'Jubiläumsfonds der Österreichischen Nationalbank' for funding our research in participatory technology development of renewable energy technologies.

\section{References}

Akrich, M., 1995. User representations: practices, methods and sociology. In: Rip, A., Misa, T.J., Schot, J. (Eds.)., Managing Technology in Society: The Approach of Constructive Technology Assessment. Pinter, London.

Allerbeck, K., Hoag, W., 1989. Utopia is around the corner: computerdiffusion in den USA als soziale bewegung. Zeitschrift für Soziologie 18 (1), 35-53.

Bröchler, S., Simonis, G., 1998. Konturen des Konzepts einer innovationsorientierten Technikfolgenabschätzung und Technikgestaltung. TA-Datenbnk-Nachrichten 7 (1), 31-40.

Faninger, G., 2000. Der Solarmarkt in Österreich 2000 (Kurzfassung) Klagenfurt/Wien, Bundesverband Solar in der Wirtschaftskammer Österreich.

Fink, C., 2002. Eine Analyse des österreichischen Solarmarktes innerhalb des ALTENER Projektes Soltherm Europe Initiative. AEEE INTEC, Gleisdorf.

Forum Vauban : Geschichte-Überblick [Web Page]. (Accessed 12. Nov. 2002). Available at: 〈http://www.forum-vauban.de/geschichte. shtml $>$.

Franke, N., Shah, S., 2003. How communities support innovative activities: an exploration of assistance and sharing among endusers. Research Policy 32, 157-178.

Gestring, N., Heine, H., Mautz, R., Mayer, H.-N., Siebel, W., 1997. Ökologie und urbane Lebensweise. Braunschweig, Vieweg.

Herstatt, C., Von Hippel, E., 1992. Developing new 'product' concepts via the lead user method: a case study in a "low-tech" field. Journal of Product Innovation Management 9, 213-221.

Hofstätter, P.R., 1986. Gruppendynamik. Rowohlt, Hamburg.

Jørgensen, U., Karnøe, P., 1995. The Danish wind-turbine story: technical solutions to political visions? In: Rip, A., Misa, T.J., Schot, J. (Eds.)., Managing Technology in Society: The Approach of Constructive Technology Assessment. Pinter, London.

Karnøe, P., 1996. The social process of competence building. International Journal of Technology Management 11 (7/8), $770-789$.

Lie, M., Sørensen, K.H., 1996. Making Technology our Own? Domesticating Technology into Everyday Life. Scandinavian University Press, Oslo.

Mackay, H., Gillespie, G., 1992. Extending the social shaping of technology approach: ideology and appropriation. Social Studies of Science 22, 685-716.

Rip, A., Kemp, R., 1998. Technological change. In: Rayner, S., Malone, E.L. (Eds.)., Human Choice and Climate Change: Resources and Technology, vol. 2. Batelle Press, Columbus, OH.

Rogers, E.M., 1995. Diffusion of Innovations. The Free Press, New York.

Rohracher, H., 2002a. Smart houses and energy efficiency. constructive technology assessment of ict use in sustainable buildings. In: Proceedings of the 2002 ACEEE Summer Study on Energy Efficiency in Buildings: Teaming for Efficiency. American Council for an Energy-Efficient Economy, Washington, DC.

Rohracher, H., 2002b. A sociotechnical mapping of domestic biomass heating systems in Austria. Bulletin of Science, Technology \& Society 22 (6), 474-483.

Rohracher, H., Ornetzeder, M., 2002. Green buildings in context: improving social learning processes between users and producers. Built Environment 28 (1), 73-84.

Schot, J., 2001. Towards new forms of participatory technology development. Technology Analysis \& Strategic Management 13 (1), 39-52. 
Shove, E., 2003. Users, technologies and expectations of comfort, cleanliness and convenience. Innovation 16 (2), 193-206.

Sperling, C., 1999. Nachhaltige Stadtentwicklung beginnt im Quartier. Ein Praxis- und Ideenhandbuch für Stadtplaner, Baugemeinschaften, Bürgerinitiativen am Beispiel des sozial-ökologischen Modellstadtteils Freiburg-Vauban. Öko-Institut, Freiburg.

Stryi-Hipp, G., 2000. The European Solar Thermal Market. In: Arbeitsgemeinschaft Erneuerbare Energie (Ed.)., Proceedings der
Tagung Gleisdorf Solar 2000. Arbeitsgemeinschaft Erneuerbare Energie, Gleisdorf

Von Hippel, E., 1988. The Sources of Innovation. Oxford University Press, Oxford/New York.

Von Hippel, E., 2001a. Innovation by user communities: learning from open-source software. Sloan Management Review 42 (4), $82-86$.

Von Hippel, E., 2001b. User toolkits for innovation. Journal of Product Innovation Management 18, 247-257. 
ANALYSIS

\title{
The environmental effect of car-free housing: A case in Vienna
}

\author{
Michael Ornetzeder ${ }^{a}$, Edgar G. Hertwich $^{b, *}$, Klaus Hubacek $^{c}$, Katarina Korytarova $^{d}{ }^{,}$Willi Haas $^{e}$ \\ anstitute of Technology Assessment, Austrian Academy of Sciences, Strohgasse 45/5, 1030 Vienna, Austria \\ bepartment of Energy and Process Engineering and Industrial Ecology Programme, Norwegian University of Science and Technology, \\ 7491 Trondheim, Norway \\ 'Sustainability Research Institute, School of Earth and Environment, University of Leeds, Leeds LS2 9JT, UK \\ ${ }^{\mathrm{d} C e n t r a l ~ E u r o p e a n ~ U n i v e r s i t y ~(C E U), ~ E n v i r o n m e n t a l ~ S c i e n c e ~ a n d ~ P o l i c y ~ D e p a r t m e n t, ~ N a d o r ~ 9, ~ H-1051 ~ B u d a p e s t, ~ H u n g a r y ~}$ \\ ${ }^{\mathrm{e}}$ The Department of Social Ecology, Institute of Interdisciplinary Studies of Klagenfurt University (IFF), Vienna, Austria
}

\section{A R T I C L E I N F O}

\section{Article history:}

Received 3 May 2006

Received in revised form

22 March 2007

Accepted 20 July 2007

Available online 4 September 2007

\section{Keywords:}

Theme housing

Car sharing

Sustainable consumption

Household environmental impact

(HEI)

Input-output analysis

Life-cycle assessment (LCA)

National accounting matrices

including environmental accounts (NAMEA)

Transportation

Urban planning

\begin{abstract}
A B S T R A C T
A case-control study of the car-free model housing project in Vienna was conducted to evaluate whether people living in this settlement have more 'sustainable lifestyles' than people living in comparable buildings in Vienna. Another aim was to identify the lifestyle characteristics and household activities which significantly influence the environmental impact of the residents of the car-free housing project and a control group. The control group, referred to as the reference settlement, was chosen from a nearby building complex, with similar characteristics, but without the car-free feature. Household consumption patterns were estimated based on interviews in combination with data from the Austrian consumer expenditure survey and the national accounts. The evaluation of household environmental impacts uses emissions estimates from the Austrian national accounting matrices including environmental accounts and data from life-cycle assessments. Households from the car-free settlement have substantially lower environmental impacts in the categories of ground transportation and energy use; their $\mathrm{CO}_{2}$ emissions of these two categories are less than $50 \%$ of those living in the reference settlement. The households in the car-free settlement have somewhat higher emissions in the categories air transport, nutrition, and 'other' consumption, reflecting the higher income per-capita. As a result, the $\mathrm{CO}_{2}$ emissions are only slightly lower than in the reference settlement, but the emissions intensity is $20 \%$ lower. Both household groups have significantly lower environmental impacts than the Austrian average reflecting less car use and cleaner heating energy in Vienna.
\end{abstract}

C 2007 Elsevier B.V. All rights reserved.

\section{Introduction}

There is a growing interest in more sustainable lifestyles and urban forms. Sustainable consumption focuses on more benign consumption patterns and greener product choices (Fritsche, 2002; Hertwich, 2005b; Jackson, 2006; United Nations
General Assembly, 1992, 2002). Urban sustainability is interested in both the liveability of urban environments and in the effects cities have on resource consumption and pollution elsewhere (Alberti, 1996; Ravetz, 2000). These efforts presume that there are lifestyles and urban forms with various degrees of environmental impacts. There is a need to evaluate different

\footnotetext{
* Corresponding author.

E-mail addresses: michael.ornetzeder@oeaw.ac.at (M. Ornetzeder), edgar.hertwich@ntnu.no (E. Hertwich).

URL's: www.oeaw.ac.at/ita (M. Ornetzeder), www.ntnu.no/indecol (E. Hertwich).
} 
alternatives and understand their effect in detail, including trade-offs between alternatives and associated rebound or ripple effects (Hertwich, 2005a). A number of different assessment approaches and indicators have been proposed (Priemus, 2005). The tradition of household environmental impact assessment goes back to cumulative energy analysis (Bullard and Herendeen, 1975; Herendeen and Tanaka, 1976; Hertwich, 2005c; Stokes et al., 1994). Lenzen et al. (2004) have shown that this method can also provide interesting insights into urban sustainability.

This study investigates differences in the patterns of consumption between two settlements that are hypothesized to have different consumption patterns. One settlement has been advertised as 'car-free'; the tenants are contractually bound to not own a car and instead have the option to participate in a car-sharing scheme. The other settlement, in close proximity and of similar age as the first, is also a theme-settlement with the title 'women's workshop'. A shared interest and perspective among the tenants hence characterizes both settlements.

Car-free housing is often named as an example for sustainable consumption. With its shared facilities, such as workshops, laundry room, activity rooms, and playgrounds, the housing project in Vienna has a good infrastructure for sustainable consumption (Briceno and Stagl, 2006; Mont, 2004). Car-free housing projects are seen as a way of getting away from frequent car use and developing more liveable, pedestrian cities with more public recreational space (GlotzRichter, 1995; Scheurer, 2001). They are part of a larger movement promoting pedestrian zones, home zones (Barrell and Whitehouse, 2004), car-sharing (Cervero, 2003; Loose et al., 2006; Prettenthaler and Steininger, 1999), and shifting the urban transportation mix towards more sustainable modes of transport (Wright and Curtis, 2005; Zacharias, 2003). Car-free housing projects have not yet been subject to academic study, except for the overview by Scheurer (2001) and the documentation of the implementation of a project in the German city of Freiburg (Fritsche, 2002; Nobis, 2003). Most car-free housing projects examined by Scheurer comprise a few dozen to hundreds of flats, sufficient to provide some local infrastructure, but insufficient to influence traffic density and travel patterns in the entire neighbourhood. Tenants of these housing projects voluntarily subscribe to public transport and giving up their cars. Preisendörfer (2001) investigated households not owning a car in Germany and found that most of those households had below average income, which suggests that the carlessness might have to do with affordability. This is not the case for the households in our samples.

Car ownership influences how people organize their lives, both daily life routines such as how to do shopping, where and how to bring kids to various places, how to get to work; and where and when to engage in leisure activities. It was expected that the car-free housing project also attracted more environmentally conscious tenants, since it was advertised as 'car-free' and as having green features such as roof-top gardens, ponds ('biotopes'), and solar hot water collectors. The research question is whether there is a measurable difference in environmental impacts between households owning a car and those that do not own a car. Do they have systematically different consumption patterns, and - if so - how large is the difference in environmental impacts? How can this difference be explained?
To answer these questions, household environmental impact (HEI) can be calculated. HEI takes into account pressures onto the environment produced by the households directly, e.g. through combusting gasoline or a heating fuel, and those 'indirect' pressures that are connected to the production of products and services consumed by the household and the disposal of household wastes (Hertwich, 2005c; Tukker and Jansen, 2006). The approach used in these studies is based on combining household expenditure data with emissions intensities of household purchases as estimated by input-output analysis and life-cycle assessment. It has the merit of providing an overview over the entire household environmental profile, including production and disposal processes. Historically, this approach has focused on energy use and later greenhouse gas emissions, and only few studies attempt to cover a whole set of life-cycle impact assessment indicators (Nijdam et al., 2005). We first included those emissions that are included in the Austrian environmental accounts: $\mathrm{CO}_{2}, \mathrm{NO}_{x}, \mathrm{AOX}, \mathrm{COD}$, energy and hazardous waste. Due to the poor data quality for a number of these indicators, we focus this paper mostly on $\mathrm{CO}_{2}$ emissions. Most studies of household environmental impact reviewed by Hertwich (2005c) focus on average households either on a national or regional level. A number of studies investigate the correlation of HEI with income and other explanatory variables (Lenzen et al., 2006) or decompose the changes over time (Munksgaard et al., 2000).

In theory, household environmental impact assessment should be well suited to compare different groups of households and to quantify the environmental benefits brought about by environmental projects and policies. Policies often focus on a specific aspect, such as energy or car use, but only an evaluation based on the entire consumption basket is able to take into account direct and some indirect rebound effects (Hertwich, 2005a). The use of household impact assessment for the evaluation of specific projects, policy measures or experiments, however, is still in its infancy. It requires a combination of methods from the social sciences and environmental systems analysis. The only project-related study we are aware of that uses such methods is related to the work in Freiburg (Brohmann et al., 2002; Fritsche, 2002). That work has mainly emphasized guiding the development of a housing project and evaluates the environmental benefits of this project only vis-à-vis a hypothetical reference settlement rather than an actual control group.

\section{Research design}

Our aim was to understand the total environmental impacts of households. It was hence important to distinguish activities which cause a high impact per unit expenditure from activities that cause an average or a low impact per unit expenditure. The emissions intensities for $\mathrm{CO}_{2}$, for example, vary between 5 and $0.05 \mathrm{~kg} / €$, with the average at $0.45 \mathrm{~kg} / €$ (Haas et al., 2005). The distribution of emissions intensities is skewed, with a few expenditure categories accounting for most of the environmental impacts. Many studies have shown that transportation by cars and airplanes, household energy, and food are by far the most important contributors to the overall household environmental impact, with energy, planes and cars having the highest emissions intensities (Hertwich, 
2005c; Tukker and Jansen, 2006). For the total environmental impact, it makes little difference whether the household spends disposable income on furniture $(0.20 \mathrm{~kg} \mathrm{CO} / €)$, textiles $(0.20 \mathrm{~kg} / €)$, watches $(0.17 \mathrm{~kg} / €)$, or health and social work $(0.16 \mathrm{~kg} / €)$. We hence did not try to distinguish such expenditures. It should be noted that rail bound transport has emissions intensities $(0.2 \mathrm{~kg} / €$ for trains and 0.3 for the subway and tram system) similar to those of manufactured goods. From an environmental perspective it hence makes no difference whether individuals spend their money on train trips or, say, on furniture.

The study was also designed to capture key socio-economic characteristics of households, their environmental motivation, and household environmental impacts (HEI) (Haas et al., 2005). A standardized questionnaire as well as qualitative interviews were used to elicit motivational and social influences that might explain differences between consumption patterns in the studies settlements. The research was conducted in the following phases:

1. Analysis of the household environmental impacts of the average Austrian household, based on expenditure data from the national accounts (Kolleritsch, 2004), supplemented by data from the 2000 Consumer Expenditure Survey (CES)(Klotz, 2002). Selection of expenditure categories and variables which are important for the overall HEI and hence to be collected from the households in stage 2 .

2. A quantitative survey eliciting overall expenditure and consumption of environmentally significant goods by households in the two settlements, plus supplementary interviews, e.g. with the building management.

3. Calculation of the HEI for each household in the samples. Comparison of the settlements and their impacts.

4. Qualitative interviews with selected households to investigate motivations for different types of behaviour relevant to variations in HEI.

The challenging part of implementing this research design was to collect data sufficient in quantity and quality to allow a representative analysis of the residents of each building. Evaluations of HEI are often based on consumer expenditure surveys (CES) collected by statistical offices. These detailed surveys require that respondents record all their expenditures over a 2-4 week period followed by an extensive interview about larger purchases such as cars and holidays. Records from a single household are not seen as representative for that household, but only for the period that was recorded, so that artificial households are assembled from different records covering an entire year (Malinvaud, 1980; Aasness et al., 1993). Since the data quality of the consumption data in the inputoutput analysis is better than that in the CES (Kronsteiner-Mann and Schachl, 2006), that data was preferred for phase 1 and for the Austrian average, unless the detail of the CES was required.

A detailed assessment of consumer expenditure as it is contained in the CES was not possible within this study. We doubt that it would be possible to find a sufficient number of participants in the respective settlements. We therefore developed an approach for estimating the household environmental impact based on data obtained in a one-hour interview with the household, including getting access to utility bills. This approach and the corresponding survey make systematic use of existing data, such as building characteristics. The survey systematically covers households' ownership of other buildings and apartments, appliances, and cars, including associated energy use and transportation. In addition, expenditure for food and hotels and restaurants are recorded. The composition of residual expenditures not covered in our survey (i.e., the less important in terms of HEI) was assumed to be similar to the categories in the household demand vector of the input-output table. The survey is documented in Haas et al. (2005).

The survey of the car-free housing project was conducted in the summer of 2004. In total, 42 households of 244 in the settlement were surveyed. It was much more difficult to find individuals who were willing to respond to the survey than we had anticipated. Given this experience, the survey was slightly simplified for the reference settlement, in which 46 households of 357 were surveyed.

Our objective was to study the environmental aspects of living in a car-free settlement and to understand the environmentally significant effects on other consumption items (rebound effects) of such a lifestyle choice. We also wanted to understand some of the social aspects and mechanisms of living in such a settlement. The novelty of this research lies in applying techniques of household environmental impact assessments to studying an individual case of sustainable consumption (Hertwich, 2005c). We did not attempt to draw a causal connection between moving to the car-free settlement and reduced environmental impact. Making such a causal claim would require a longitudinal survey, which is more expensive to carry out. Nevertheless, through our questionnaire we do try to get some indication of how people have changed their behaviour since moving to the car-free settlement. Neither did we attempt to study the travel behaviour of the residents in great detail; that is, what means of transportation were used by whom, when and for what purpose. Such a study would require a diary-based approach and could not rely on a survey alone. While such a detailed travel survey would provide significant insights, it was not our aim to study transportation in such a detail. Rather, it was to identify differences in the household environmental profiles based on the main consumption items (including transport) with regards to emission intensities between the car-free settlement and a control group.

\section{The two settlements in comparison}

Both samples show a similar socio-economic structure, as Table 1 indicates. The households are of similar size, the available living space is of similar dimension, and the level of education of respondents in both settlements is far above the Viennese average. Because both settlements are relatively new and located in the same district of Vienna, it is not astonishing that the selected settlements are inhabited by people with similar socio-economic and cultural backgrounds. We observe rather homogenous social milieus.

In both settlements - in the car-free and the reference project - the average size of households is above the Viennese average (Table 1). Although large housing projects at the 
periphery typically attract young families, this is only partly true for our cases. In the car-free settlement, as well as in the reference project, nearly every second household is childless. Every fourth household in the car-free project is a single household. Just as many households are inhabited by only two persons. All in all it seems that there are slightly more large families and in total more children in the reference settlement than in the car-free project. Nevertheless, there are fewer singles and more families with children than the Viennese average.

Respondents in both samples are better educated than the Viennese population. Especially in the car-free settlement a high percentage of the inhabitants has a university degree. The concept of the project - to organize mobility without private car - was obviously attractive for persons with a high formal qualification. According to their level of education people in both settlements are working predominantly in white-collar jobs. Males could often be found in trendsetting industries like in IT or higher education. Many of the female occupants work as school teachers, as office workers, or in the health care system.

Given the high percentage of well educated people in both samples it is notable that the average family income in the selected settlements is not much above the Viennese average. In relation to the number of persons per household it is clearly below the average. Interesting is also the fact that both samples

Table 1-Average household characteristics in the two samples and Vienna at large

Car-free Reference Vienna project settlement

\begin{tabular}{|c|c|c|c|}
\hline $\begin{array}{l}\text { Average number of } \\
\text { people per household }\end{array}$ & 2.57 & 2.76 & 1.96 \\
\hline $\begin{array}{l}\text { Average number of } \\
\text { children per household } \\
\text { Occupation of } \\
\text { respondents }\end{array}$ & 0.67 & 0.91 & 0.55 \\
\hline White-collar worker & $52.4 \%$ & $52.2 \%$ & $25.3 \%$ \\
\hline Blue-collar worker & $8.7 \%$ & $2.5 \%$ & $13.3 \%$ \\
\hline Civil servant & $14.3 \%$ & $6.5 \%$ & $13.0 \%$ \\
\hline Self-employed & $2.4 \%$ & $4.3 \%$ & $5.7 \%$ \\
\hline Retired & $11.9 \%$ & $6.5 \%$ & $28.8 \%$ \\
\hline In-training & $7.1 \%$ & $8.7 \%$ & $8.5 \%$ \\
\hline Unemployed & $4.8 \%$ & $4.3 \%$ & $5.6 \%$ \\
\hline \multicolumn{4}{|l|}{ Education } \\
\hline Secondary school & $7.2 \%$ & $8.7 \%$ & $33.2 \%$ \\
\hline Vocational school & $4.8 \%$ & $15.2 \%$ & $28.6 \%$ \\
\hline Technical school & $4.8 \%$ & $10.9 \%$ & $10.6 \%$ \\
\hline A-levels & $38.1 \%$ & $39.1 \%$ & $15.8 \%$ \\
\hline University degree & $45.2 \%$ & $23.9 \%$ & $11.8 \%$ \\
\hline $\begin{array}{l}\text { Average annual net } \\
\text { income (Euro) }\end{array}$ & 32282 & 30867 & 28320 \\
\hline Minimum (Euro) & 9100 & 7000 & \\
\hline Maximum (Euro) & 72800 & 75000 & \\
\hline $\begin{array}{l}\text { Average annual net } \\
\text { income per capita (Euro) }\end{array}$ & 12560 & 11180 & 19720 \\
\hline Average size of flat $\left(\mathrm{m}^{2}\right)$ & 86.00 & 82.60 & 70.90 \\
\hline $\begin{array}{l}\text { Average size per person } \\
\left(\mathrm{m}^{2}\right)\end{array}$ & 33.50 & 30.00 & 36.20 \\
\hline Minimum $\left(\mathrm{m}^{2}\right)$ & 50 & 47 & \\
\hline Maximum $\left(\mathrm{m}^{2}\right)$ & 130 & 107 & \\
\hline
\end{tabular}

Table 2 - Selected information on transport

\begin{tabular}{lrr} 
Selected types of transport & $\begin{array}{r}\text { Car-free } \\
\text { project }\end{array}$ & $\begin{array}{r}\text { Reference } \\
\text { settlement }\end{array}$ \\
\hline $\begin{array}{l}\text { Bicycle use - more than } \\
\text { 200 days in 2003 }\end{array}$ & $36 \%$ & $9 \%$ \\
$\begin{array}{l}\text { Public transit - annual pass } \\
\text { (fraction of individuals) }\end{array}$ & $48 \%$ & $24 \%$ \\
$\quad \begin{array}{lr}\text { Austrian railways - discount card } \\
\text { Car }\end{array}$ & $47 \%$ & $10 \%$ \\
$\quad$ Households with 0 km in 2003 & $55 \%$ & $30 \%$ \\
$\quad$ Fraction of km with car-sharing/ & $49 \%$ & $0.8 \%$ \\
rental & & \\
$\begin{array}{l}\text { Airplane; households with no flights } \\
\text { in 2003 }\end{array}$ & $48 \%$ & $52 \%$ \\
$\begin{array}{l}\text { Average distance per household in } \\
\text { 2003 (km) }\end{array}$ & & \\
$\quad$ By car & & \\
$\quad$ By train, bus, ship (excluding & 700 & 10979 \\
commuting) & 6674 & 1489 \\
$\quad$ By airplane & & \\
Sum & 6686 & 6237 \\
\end{tabular}

The distances do not include commuting by public transport, walking and biking, as the distances for these modes of transport have not been determined.

contain high and low-income households; families with very different financial resources are living next to each other.

The size of the flats ranges between 50 and $130 \mathrm{~m}^{2}$. The average size in the car-free project is $86 \mathrm{~m}^{2}$, compared to $82.6 \mathrm{~m}^{2}$ in the reference project. Flats are larger compared to the Viennese average $\left(70 \mathrm{~m}^{2}\right)$, but per capita the living space is below average. In the car-free settlement the average living space is $33.5 \mathrm{~m}^{2}$ per person, compared to $30 \mathrm{~m}^{2}$ in the reference settlement. In other words the average 'consumption' of living space in the reference project is $10 \%$ below the car-free settlement and even $20 \%$ below the Viennese average.

Equipment ownership is slightly higher in the reference settlement, except for TV-sets. There are only a few clothdryers $(9.5 \%$ in the car-free project vs. $6.5 \%$ in the reference settlement). Most households own one or more computers, and about $75 \%$ have a connection to the internet. In the carfree settlement, only one of the 42 households owns a car, ${ }^{1}$ whereas in the reference settlement, $67 \%$ of the households own a car, $11 \%$ even more than one; in comparison, about $81 \%$ of the households in Vienna own a car (MA5, 2006). In both settlements almost everybody owns a bike.

As expected the results for mobility show significant differences between the two settlements (see Table 2 for selected results). Car-free households use public transport, whereas for the reference-households the car is the most important means of transportation. Car-free households have slightly more air trips and longer distances than the reference group, although the difference is not large. The overall mileage of the average car-free household - covered by car, train, bus, ship and airplane - was clearly below the reference group. While car-free households have travelled an average distance of about

${ }^{1}$ This is in violation with the contract, but the householder argues that he needs it for his job. 
$14,000 \mathrm{~km}$, reference households travelled almost 19,000 km. Note, however, that these distances do not include commuting on the local public transportation system, biking or walking.

In the car-free settlement cars play indeed a very limited role to meet private transport needs - therefore residents match the aim and label of the project rather well. In 2003, more than half of the car-free households did not use a car at all (Table 2). The one household owning a car is responsible for more than $60 \%$ of total car mileage in the car-free settlement sample. The remaining mileage was covered by car-sharing, rental or borrowed cars. According to our respondents the most important reason to use a car is to do purchases of bulky items. The situation is quite different in the reference project. Most of these households own at least one private car which is the main means of mobility of the family. On average each household in the reference settlement drives $11,000 \mathrm{~km}$ per year. The reference value in the car-free settlement is $700 \mathrm{~km}$.

\section{Household environmental impact calculations}

Household environmental impact assessment has been pioneered in the field of energy analysis with the calculation of embodied and direct energy use by different household groups. The first analyses of this type by Herendeen and others (Bullard and Herendeen, 1975; Herendeen, 1978; Herendeen and Tanaka, 1976) already combined energy inputoutput analysis (IOA) to estimate the energy use for the products and services consumed by a household with data on the consumption of different energy carriers by the households themselves. Today, this type of analysis also takes into account emissions and potentially resource use and material flows. For a review of the literature, see Hertwich (2005c). The objective of this type of analysis is to quantify the contribution of different household activities or demand categories, such as food, clothing, transportation and dwellings, to the overall household environmental impact.

In this study, we started by analysing the environmental impact of the average Austrian household, using input-output tables for 2000 (Kolleritsch, 2004), the environmental accounts of 1999/2000 for air emissions and energy and of 1995 for AOX and COD (Eurostat, 2001), and data from the 1999/2000 consumer expenditure survey (Klotz, 2002). We found that transportation and energy use in households are the most important contributors to greenhouse gas emissions (Haas et al., 2005). Direct energy use and transportation are usually not or only incompletely represented in input-output analyses, so we decided to use direct emissions calculations and life-cycle assessment (LCA) data to model these impacts.

\subsection{Input-output analysis}

Emissions intensities of commodities in basic prices were calculated following the standard equation

$M=F(I-A)^{-1}$

Where A represents the input-output coefficients in commodity-commodity formulation calculated from make and use tables using the industry-technology assumption. The input-output coefficients include both domestic and imported products $A=A^{d}+A^{i}$ (Peters and Hertwich, 2004), where imports are treated as if they were produced domestically. The matrix $F$ depicts the emissions or resource use per unit commodity produced. ${ }^{2}$ Emissions and resource use per industry sector are allocated to commodities using the normalized make table, i.e. reflecting the industry-technology assumption. The problem with using the Austrian environmental accounts as sources for environmental pressures is that data exists for only a limited number of stressors $\left(\mathrm{CO}_{2}, \mathrm{NO}_{x}, \mathrm{COD}, \mathrm{AOX}\right.$, hazardous waste, energy). A comprehensive assessment of impact categories as used in LCA (Udo de Haes et al., 2002) is therefore not possible. The data for some of these categories is outdated and of poor quality, only the results for $\mathrm{CO}_{2}$ emissions are of better quality because they need to be reported to the UNFCCC.

The emissions intensities of different commodities in purchaser prices were calculated from those in basic prices using tables on trade and transport margins, taxes and subsidies for the different products. The tables include information on which sectors produce the different margins, so that the emissions connected to trade and transport are included in the emissions intensities of the commodities. The results indicate that there are many services and products which have similar emissions per unit expenditure. The emissions intensities vary between $0.05 \mathrm{~kg} \mathrm{CO}_{2} / €$ for education to $0.56 \mathrm{~kg} \mathrm{CO}_{2} / €$ for paper. Very few commodities show higher intensities. Some of these are not purchased by households directly, e.g. basic metals (1.5 kg CO$/ €)$. We decided not to try to determine the purchase of less important commodities with emissions intensities that are not far from the average commodity, because variations in the purchase of these commodities would not have a significant impact on the overall household environmental impact. Rather, we decided to focus on purchases that typically contribute considerably to the total. These are commodities with high emission intensities, such as energy and land transport (1.5 and $\left.1.7 \mathrm{CO}_{2} / €\right)$, and commodities which take up a significant part of the household budget (food, hotels and restaurants).

\subsection{Life-cycle analysis}

We use data from the Eco-Invent database (Frischknecht, 2004) for the Austrian electricity mix and for trains, coaches, and airplanes. For green electricity, we use the LCA numbers for a Swiss wind power plant. For car transport, all data is based on the LCA of a VW Golf A4 (Schweimer and Levin, 1999). Data relating to car production and maintenance was

\footnotetext{
${ }^{2}$ We had to produce our own A table because Statistics Austria provides an A table only for the commodity-technology assumption in commodity-commodity formulation while emissions data exists only on an industry basis. Manual manipulations are involved in producing the A table, and we could not reproduce this so that we were not able to allocate industry emissions to the commodities as represented by the A table. Different practices exist in HEI assessments. Lenzen (2001) also combines make and use table using the industry-technology assumption, while Peters and Hertwich (2006) use the A table provided by the Statistical office.
} 
Table 3 - Distribution of per capita household environmental impacts (HEI) in 2000 based on input-output calculations

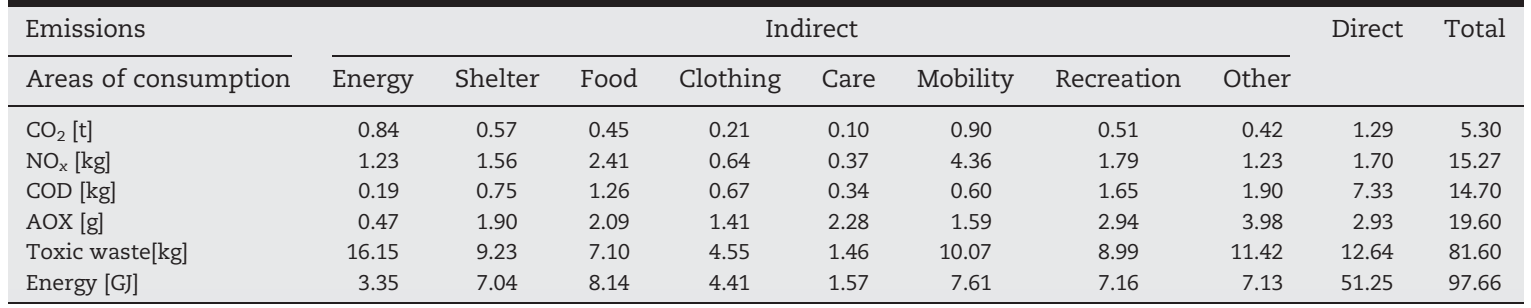

captured in a per-km component. This assumes that the production and maintenance of all cars causes about as much pollution as the Golf A4. The fuel-related and direct emissions were captured in a per-liter component. Road infrastructure was not considered. Emissions for district heating were obtained from the regional utility (Wallisch, 2004). We included only direct emissions, not emissions connected to building the infrastructure. Emissions from using the city's public transport system were calculated from the energy use of Vienna's transport system (Wiener Linien, 2004), passenger number, and appropriate emissions coefficients for buses fuelled with natural gas (Beer et al., 2000). Again, the life-cycle assessment was not complete as the infrastructure was not considered. The use of such incomplete assessments is not ideal but can justified by the finding that for energy using products, the energy use usually dominates in the LCA results (Hanssen, 1998).

\section{Comparison of impacts}

Table 3 presents the average per capita direct and indirect emissions in Austria as obtained from the input-output calculations. This assessment does not include direct emissions from transport, because the input-output tables do not specify the direct emissions for household transportation. The reported transportation could not be assigned to specific user groups based on this information. From the transportation survey, we estimated the average $\mathrm{CO}_{2}$ emissions to be $0.6 \mathrm{t} /$ person. The calculations assumed that all products and services consumed have been produced by using Austrian production technology, no matter whether they have been produced domestically or have been imported. This is likely to result in an underestimate of certain emissions, e.g. those connected to clothing and other consumer goods (Peters and Hertwich, 2006), but those emissions are not the focus of our study.

The comparison of the two settlements uses the inputoutput calculations only for part of the emissions, as described in the methods section. The evaluation of emissions of the two settlements in Table 4 indicates that in some categories, the car-free settlement has lower per capita environmental impacts, while in other categories the reference settlement is better. The difference is never more than $20 \%$. For all indicators, the average Austrian household has higher impacts, and it also has higher expenditures. Please note that the numbers for toxic waste generation and energy use are somewhat more uncertain than the other numbers. The data for primary energy use for the energy and transport categories was estimated. The assessment of toxic waste was based only on the IO table. Because of uncertainties in the emissions factors used in connection with the IOA and the data in the underlying LCA, the emissions estimates for $\mathrm{AOX}, \mathrm{COD}$, and $\mathrm{NO}_{x}$ are more uncertain than those for $\mathrm{CO}_{2}$, which can be calculated quite accurately from a carbon balance.

In the following analysis we will focus on $\mathrm{CO}_{2}$ emissions, because of the better data quality and because of the importance of global warming in the current public debate. Fig. 1 shows a comparison of the two settlements and the Austrian average using the categories we have distinguished in our calculations. Different types of transportation are specified: public transportation in Vienna, public transportation for recreation/trips/holidays (i.e. airplanes, trains, busses, ships), and use of cars, mopeds and motorcycles. The households in the car-free settlement have lower per capita $\mathrm{CO}_{2}$ emissions. Per Euro spent, the car-free settlement has $20 \%$ lower $\mathrm{CO}_{2}$ emissions than the reference settlement. Transportation's share of the household $\mathrm{CO}_{2}$ emissions is lower for the car-free settlement (35\%) than for the reference settlement $(44 \%)$ and the average Austrian household (42\%). In the car-free housing project, the emissions associated with energy are $25 \%$ lower than in the reference settlement, because there households use $30 \%$ less electricity and have more subscribers of green electricity, which causes only $10 \%$ of the emissions of the gridaverage. The energy-related emissions are much lower in the two Viennese settlements than in Austria on average, because of the use of district heating for heating and hot water. Since waste incineration, an important heat source in Vienna, is treated as 'carbon neutral,' the $\mathrm{CO}_{2}$ emissions are much lower than those from oil and natural gas, the most important heating fuels in other urban, suburban and rural areas.

The overall differences between the settlements in $\mathrm{CO}_{2}$ emissions and energy use are lower than the variations within

Table 4 - Comparison of annual per capita household environmental impact and expenditure between the two settlements and the average Austrian household

\begin{tabular}{lccccccc} 
& $\mathrm{CO}_{2}[\mathrm{t}]$ & $\mathrm{NO}_{\mathbf{x}}[\mathrm{kg}]$ & $\mathrm{COD}[\mathrm{kg}]$ & $\mathrm{AOX}[\mathrm{g}]$ & Toxic waste $[\mathrm{kg}]$ & Energy $[\mathrm{G}]$ & Expenditure $[\mathrm{k} €]$ \\
\hline Car-free & 4.2 & 14 & 10 & 15 & 61 & 75 & 12.7 \\
Reference & 4.5 & 13 & 9 & 13 & 54 & 80 & 11.2 \\
Average & 7.0 & 16 & 11 & 16 & 72 & 101 & 14.3 \\
\hline
\end{tabular}




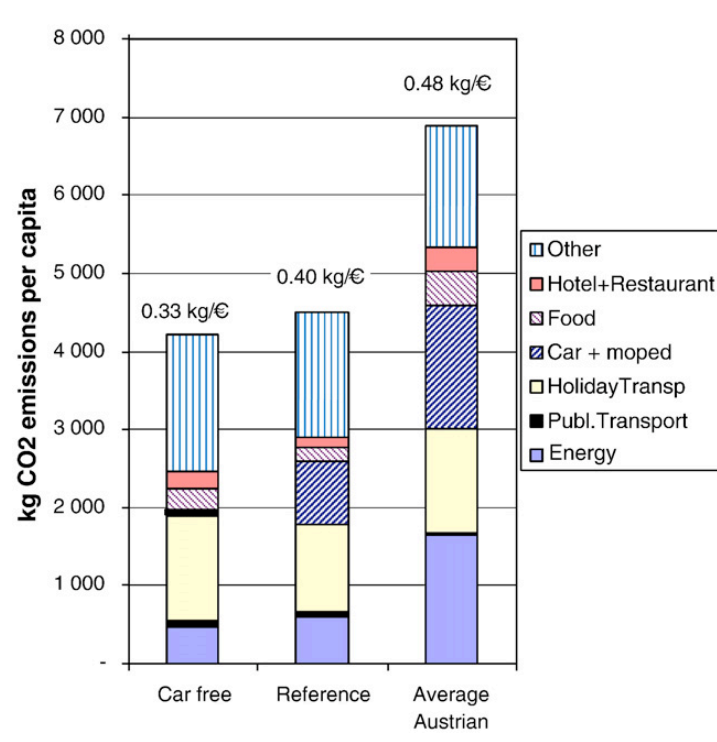

Fig. 1-Per capita $\mathrm{CO}_{2}$ emissions (in $\mathrm{kg} /$ capita) and average emission intensities (in $\mathrm{kg} /$ Euro) of the two settlements in comparison with the average Austrian.

the settlements. This may come as a surprise, but this result is not that difficult to explain:

- For the car-free settlement, 53\% of the emissions are caused by the categories food, hotels and restaurants, and 'other,' which are estimated using input-output analysis. To estimate the 'other' emissions, we used a typical expenditure pattern as derived from the consumer expenditure survey. Any systematic variation in these expenditures is not covered by our assessment. The car-free settlement has a slightly higher income, which results in a higher impact in the 'other' category ( $42 \%$ of total $\mathrm{CO}_{2}$ emissions, vs. $35 \%$ in the reference settlement). In the categories assessed by LCA, the reference settlement had $33 \%$ higher $\mathrm{CO}_{2}$ emissions per capita than the car-free settlement.

- The rebound effect is important (Hertwich, 2005a). It is assumed here that everybody spends all their income; any money saved by not owning a car goes to some other purpose. The 'other' category has only $14 \%$ of the emissions intensity of cars (Table 5). If the money saved by not owning a car is spent on air transport, much higher emissions can result. As far as we could determine, these households eat more out and have a higher consumption in the 'other' category.

- For the car-free settlement, air transport accounts for $64 \%$ of the $\mathrm{CO}_{2}$ emissions associated with energy and transport. For the reference settlement, this number is only $43 \%$. The per capita $\mathrm{CO}_{2}$ emissions of energy and transport not consider- ing air transport are $720 \mathrm{~kg}$ (16\% of total) in the car-free settlement and $1500 \mathrm{~kg}(36 \%)$ in the reference settlement. The car-free settlement also has a lower emissions intensity value for holiday transport including air transport, because of the use of trains and buses instead of the car.

Past investigations of energy use and of $\mathrm{CO}_{2}$ emission of households based on CES have shown that both variables are a strong function of income (Herendeen, 1978; Herendeen and Tanaka, 1976; Lenzen et al., 2006; Moll et al., 2005; Stokes et al., 1994; Vringer and Blok, 1995; Wier et al., 2001). Income elasticities of energy use are commonly between 0.6 and 0.9 (Hertwich, 2005c). This result may be, to a certain degree, a modelling artefact, because indirect energy use and emissions were mostly determined with IOA and therefore are systematically correlated with the expenditure level. In addition, environmental differences between, e.g. buying one luxury car or two inexpensive family cars at the same cost cannot be distinguished. Similarly, spending more money on buying organic food is modelled as resulting in higher impacts compared to buying the same products from conventional products. This problem of course also affects our study. Despite these shortcomings the investigation of the relationship between expenditure and $\mathrm{CO}_{2}$ emissions still provides some interesting insights.

Fig. 2a indicates that in our two samples, there is a fairly wide scatter of $\mathrm{CO}_{2}$ emissions especially for higher income. The situation changes when we subtract air transport, as Fig. $2 b$ shows. There is a high correlation between income and $\mathrm{CO}_{2}$ emissions for households across settlements that do not own a car. The income elasticities are similar, 0.88 and 0.82 , as the power-law fit in Fig. $2 b$ shows; that is, the car-free households in the reference settlement are very similar to the car-free settlement. For the car-owning tenants of the reference settlement, however, the correlation of emissions with income is much lower and the income elasticity is only 0.44. This is a very interesting result: the car establishes a 'necessity' with a 'stable' $\mathrm{CO}_{2}$ emission level relatively independent of income. It implies that once the car has been purchased, behaviour - that is, car use - becomes more important while the relative importance of income for household $\mathrm{CO}_{2}$ emissions decreases.

Looking at our whole sample, there is little correlation between income and air transport $\left(r^{2}=0.03\right)$ and no correlation between the $\mathrm{CO}_{2}$ emissions of ground transport and air travel. In our sample, there is hence no indication that the money saved from not owning a car is systematically diverted to air travel.

Table 5 indicates the $\mathrm{CO}_{2}$ intensity of the different consumption categories investigated. Most consumption categories contain emissions intensities either from several IO categories ('other') or from life-cycle assessment, and they are weighted results. The low emissions intensity for 'car and moped transport' for the car-free settlement, for example, results from the fact that car rental/sharing is more expensive per $\mathrm{km}$. It shows that many categories have a similar $\mathrm{CO}_{2}$ intensity.

Table $5-\mathrm{CO}_{2}$ emissions intensity in $\mathrm{kg} \mathrm{CO}_{2} / €$ for different expenditure categories

\begin{tabular}{lcccccccc} 
& Energy & Public transport & Holiday transport & Car moped & Food & Hotel restaurant & Other & Total average \\
\hline Car-free & 0.96 & 0.35 & 4.50 & 0.54 & 0.24 & 0.18 & 0.19 & 0.33 \\
Reference & 1.50 & 0.47 & 7.37 & 1.45 & 0.24 & 0.18 & 0.19 & 0.40 \\
Average & 3.08 & 0.40 & 6.52 & 1.49 & 0.24 & 0.18 & 0.19 & 0.49 \\
\hline
\end{tabular}



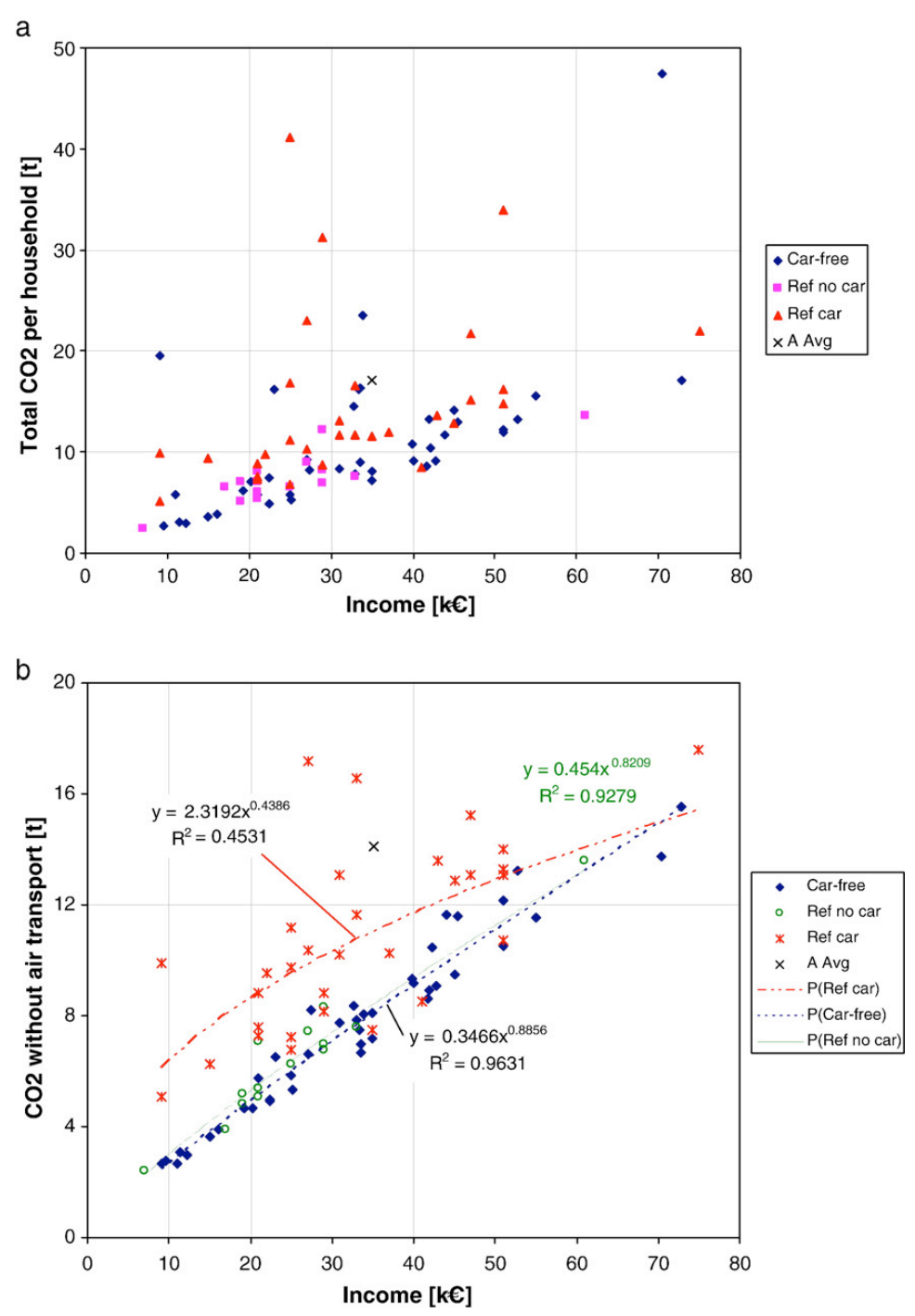

Fig. 2-Total $\mathrm{CO}_{2}$ emissions per household, (a) with and (b) without air transport, as a function of household income. For the reference settlement (ref), we distinguish between households with and without cars.

Only those with intensities significantly different from the average can cause substantial deviations from a linear relationship between expenditure and $\mathrm{CO}_{2}$ emissions. For our two samples, these are air transport, energy use, and car use. The physical design of the buildings (insulation, heating system, design) conditions much of the energy use, so that only car use and air planes contribute to a substantial difference among the samples. There seems to be no correlation between car use and income in the reference settlement.

\section{Social aspects of consumption choices}

The survey indicates that there are two distinct causes for the lower $\mathrm{CO}_{2}$ emissions in the car-free settlement: differences in the mobility patterns and the popularity of green electricity. Environmental effects of other ecological behaviour, such as recycling, the purchase of organic food and low-meat diets could not be determined in this study. We reasoned at the outset that both infrastructure aspects (e.g. bicycle parking and repair facilities) and social mechanisms that define 'normal' behaviour would be important for shaping the consumption patterns in the car-free settlement. We were interested in how the tenants perceived this settlement, how they interacted with their neighbours, what motivated the choice of moving to the settlement, and whether moving there resulted in a change of behaviour. In preparing for the survey, we conducted 5 interviews with building managers and the tenants' representatives. In the survey, there was a number of questions relating to motivations, neighbourly relationships, self-perception and 
Table 6 - The most important motivations to move to the settlement

\begin{tabular}{lcc}
$\begin{array}{l}\text { Five most important } \\
\text { motivations }\end{array}$ & $\begin{array}{c}\text { Car-free } \\
\text { project (\%) }\end{array}$ & $\begin{array}{c}\text { Reference } \\
\text { settlement (\%) }\end{array}$ \\
\hline $\begin{array}{l}\text { Recreation area 'Alte Donau' } \\
\text { Generous common areas and } \\
\text { facilities }\end{array}$ & 85 & 58 \\
To live in a 'green' and & 73 & 17 \\
healthy environment & & 61 \\
$\begin{array}{l}\text { Quiet site/no noise pollution } \\
\text { Bright, sunny apartment }\end{array}$ & 71 & 61 \\
Need for more living space & 68 & 54 \\
Good floor plan & 44 & 63 \\
\hline For a full list, see Haas et al. (2005). & 46 & 61 \\
\hline
\end{tabular}

perception of others, and ecological motivation. After the survey, we conducted four in-depth interviews in the car-free settlement with residents representing typical styles of consumption.

\subsection{The role of infrastructure}

We asked tenants to list the five most important motivations for moving to the settlement. Our survey follows a postoccupancy survey which was conducted 18 months after the car-free settlement was opened (Gutmann and Havel, 2000). The results in Table 6 indicate that for the car-free project, the proximity to the recreation area 'Alte Donau', the shared facilities and the quality of the surroundings are the most important motivating factors. The car-free feature was less important. Only 10 out of 42 respondents have mentioned the car-free feature as relevant for their decision. These results are similar to those obtained in the post-occupancy survey (Gutmann and Havel, 2000). For the reference settlement more reasons for moving into the settlement were named. There was a larger share of people who needed to move, but the attributes of the apartments and surroundings were also important.

The car-free feature and the ecological aspects were decisive for only a minority of tenants who moved to the settlement. According to the post-occupancy survey, only $50 \%$ of the male and $30 \%$ occupants have owned a car at any time of their life (Gutmann and Havel, 2000). We do not know the shares for the reference settlement but it is important to note that the mobility patterns of the tenants of the car-free

\section{Table 7 - Ecological awareness in the settlement}

\begin{tabular}{lcc} 
Statements & $\begin{array}{c}\text { Car-free } \\
\text { project (\%) }\end{array}$ & $\begin{array}{c}\text { Reference } \\
\text { settlement (\%) }\end{array}$ \\
\cline { 2 - 3 } & Very and fairly true \\
\hline $\begin{array}{l}\text { In this settlement we have much } \\
\text { more ecofriendly people than in } \\
\text { similar settlements }\end{array}$ & 92 & 27 \\
$\begin{array}{l}\text { Waste separation is very } \\
\text { important in this settlement }\end{array}$ & 44 & 20 \\
$\begin{array}{l}\text { Green consumption is an } \\
\text { important topic of conversation in } \\
\text { this settlement }\end{array}$ & 34 & 2 \\
\hline
\end{tabular}

Table 8 - Social control regarding ecological behaviour

\begin{tabular}{|c|c|c|}
\hline \multirow[t]{2}{*}{ Statements } & $\begin{array}{c}\text { Car-free } \\
\text { project (\%) }\end{array}$ & $\begin{array}{c}\text { Reference } \\
\text { settlement (\%) }\end{array}$ \\
\hline & \multicolumn{2}{|c|}{ Very and fairly true } \\
\hline $\begin{array}{l}\text { Everybody knows everything } \\
\text { about other people in the } \\
\text { settlement }\end{array}$ & 24 & 19 \\
\hline $\begin{array}{l}\text { Sometimes I observe that } \\
\text { neighbours do not separate their } \\
\text { waste }\end{array}$ & 26 & 11 \\
\hline $\begin{array}{l}\text { If somebody from the settlement } \\
\text { buys a new car, everybody will } \\
\text { know it }\end{array}$ & 49 & 5 \\
\hline
\end{tabular}

settlement are significantly different from those of the reference settlement:

- According to our results it is clear that bicycles are a major means of transportation in the car-free settlement; and the existing facilities support this mode of transport to a certain extent. Easy access to and space for bikes were already important topics during the planning process of the buildings. Future tenants argued for additional bicycle sheds - against the landscape planner's initial concept - and succeeded. Although households in both settlements are quite well equipped with bicycles (with approximately one bike per person), the use patterns differ significantly. While in the car-free project $36 \%$ of all respondents have used their bicycle on more than 200 days in the year 2003, only $9 \%$ showed the same extensive bike use in the reference settlement. ${ }^{3}$ Despite this large difference it is difficult to assess the role of the bike-friendly facilities. Those conditions are important, but perhaps only a part of the overall setting. It seems that many people, when they move to the carfree settlement, change their mobility habits. For example, $41 \%$ of the respondents say that they have started to use their bicycle much more often than before (reference settlement: $22 \%$ ).

- We know from some of the qualitative expert interviews that car-sharing in the car-free project was less 'successful' than the car-sharing company had expected. They started with five cars, but due to little interest the company had to reduce the number to three. The results from our survey could also be interpreted in this way. Only $41 \%$ of all respondents have used car-sharing during the studied period, the year 2003, and covered an average distance of about $600 \mathrm{~km}$. In comparison only $7 \%$ of households in the reference settlement (without car-sharing facility) have used car-sharing in 2003. Although it is very easy to rent a car in the

${ }^{3}$ These results were obtained by interviews and are hence based on recollection. The travel survey literature indicates that recollection-based estimates are less reliable than estimates from travel dairies. The difference between the two samples is so large, however, that we are confident that it is real.

${ }^{4}$ In one of the interviews this change is described in the following words:'...it is because of this settlement that I am living again in a bicycle-friendly environment. When I came here, I bought a new bike, and I use it a lot. I was used to do things this way many years ago, than I had no bike for about 10 years. Since I moved here, I have been using my bike for many different trips' (interview 1). 


\section{Table 9 - Identification with the settlement}

\begin{tabular}{lcc} 
Statements & $\begin{array}{c}\text { Car-free } \\
\text { project (\%) }\end{array}$ & $\begin{array}{c}\text { Reference } \\
\text { settlement (\%) }\end{array}$ \\
\cline { 2 - 3 } & Very and fairly true \\
\hline $\begin{array}{l}\text { Many tenants are proud to live in } \\
\text { our settlement } \\
\begin{array}{l}\text { Compared to other new } \\
\text { settlements in the neighbourhood } \\
\text { our settlement is very special }\end{array}\end{array}$ & 82 & 29 \\
\hline
\end{tabular}

car-free settlement, tenants use this offer quite hesitantly. Most car-free households cover their mobility needs by means of public transport and bicycle. On average, car-free households travel 10 times as far by train as by car and bus. In contrast, train transport covers only $13 \%$ of the distance of car transport for respondents in the reference settlement.

\subsection{Attitudes and perceptions}

A number of questions in the survey addressed both the importance of environmentally friendly consumer behaviour and of attitudes and perceptions. Most of the respondents think that there are much more eco-friendly people in the car-free settlement than in similar settlements in Vienna. In contrast only a minority in the reference settlement feels confident with this statement. Differences between the two settlements with regards to behaviour are also indicated by the importance of waste separation and green consumption as a topic of daily conversations in the car-free settlement. One third of all respondents in the car-free settlement think that green consumption is a relevant and frequent topic. In the reference settlement only one of all (46) interviewed persons shares that opinion. There is a clear difference in the perception of the general ecological awareness between the settlements. Ecological awareness plays a more important role as part of the social norms. It can be expected to act as reinforcing certain behaviours in the carfree settlement than in the reference settlement (Table 7).

\subsection{Social cohesion and social control}

Another important element of the social conditions within groups and more specifically within a settlement is social control. For our problem it was important to measure forms of social control regarding the ecologically relevant behaviour. Here the relevant question is as follows: To what extent do tenants recognize how other people in the settlement live? We have used several items to measure this question. In all cases the results show clear differences between the two settlements. In the carfree settlement the share of well informed tenants is much higher than in the reference group. It seems, however, that with the exception of car non-use, social control is not a big issue. Half of the respondents believe that it would not be possible for tenants to buy a car without everybody knowing it (Table 8).

Although both case settlements have been developed around a specific theme, car-free living versus for women-designed housing, the identification with the settlement seems to be much higher in the car-free project. Eight of ten respondents in the car-free settlement think that 'many tenants are proud to live especially in the car-free settlement'. In comparison, in the
Table 10-Social cohesion in the settlement

\begin{tabular}{lcc}
\hline Statements & $\begin{array}{c}\text { Car-free } \\
\text { project (\%) }\end{array}$ & $\begin{array}{c}\text { Reference } \\
\text { settlement (\%) }\end{array}$ \\
\cline { 2 - 3 } & \multicolumn{2}{c}{ Very and fairly true } \\
\hline $\begin{array}{l}\text { The solidarity within the } \\
\text { settlement is very strong }\end{array}$ & 87 & 24 \\
$\begin{array}{l}\text { There are good neighbourly } \\
\text { relationships in this settlement } \\
\begin{array}{l}\text { To help each other is very } \\
\text { common in this settlement }\end{array}\end{array}$ & 85 & 18 \\
\hline
\end{tabular}

reference settlement only three out of ten respondents think that this view is shared by their neighbours. This is further exemplified by the statements presented in Table 9 .

With regards to social cohesion the comparison between the two settlements shows significant differences as well: While most of the respondents in the car-free settlement are convinced that social cohesion is very strong in their neighbourhood, in the reference settlement only a minority believes this to be true. Similarly, more than eight of ten carfree tenants think that 'the solidarity within the settlement is very strong', that 'there is a good neighbourly atmosphere' and that it is 'very common to help each other'. Only this last point regarding the helpfulness in the settlement seems to be of some relevance in the reference settlement as well (Table 10) .

We know from some of the qualitative interviews that there is a very active community in the car-free settlement. Every year there are some self-organised festivities and flea markets in the courtyard. Moreover, most of the common facilities in the car-free settlement are managed by some residents themselves. Therefore it is not surprising that all respondents (100\%) in the car-free settlement say that there are 'many joint activities for all residents.' In the reference settlement only one out of ten subscribes to this statement. In general, residents in the car-free settlement maintain much more social contacts with neighbours in their settlement. On average respondents in the car-free settlement estimate that they have 16 friends in the settlement and know more than 100 by sight, compared to 7 friends and 62 known neighbours in the reference settlement. In the car-free settlement it is also more likely that people did know some residents before they moved in (Table 11) .

\subsection{Information flow}

Finally, there are also clear differences between the two settlements regarding the possibilities and ease to get

Table 11 - Social contacts within the settlement

\begin{tabular}{|c|c|c|}
\hline \multirow[t]{2}{*}{ Questions } & $\begin{array}{l}\text { Car-free } \\
\text { project }\end{array}$ & $\begin{array}{l}\text { Reference } \\
\text { settlement }\end{array}$ \\
\hline & \multicolumn{2}{|c|}{$\begin{array}{c}\text { Number of people } \\
\text { (average) }\end{array}$} \\
\hline $\begin{array}{l}\text { How many people in the settlement } \\
\text { would you call 'friends'? }\end{array}$ & 16 & 7 \\
\hline $\begin{array}{l}\text { How many people did you already know } \\
\text { before you moved to this settlement? }\end{array}$ & 2.7 & 0.2 \\
\hline $\begin{array}{l}\text { How many residents do you know by } \\
\text { sight? }\end{array}$ & 101 & 62 \\
\hline
\end{tabular}


Table 12 -Information about environmentally friendly consumption in the settlement

\begin{tabular}{lcc} 
Statements & $\begin{array}{c}\text { Car-free } \\
\text { project } \\
(\%)\end{array}$ & $\begin{array}{c}\text { Reference } \\
\text { settlement (\%) }\end{array}$ \\
\cline { 2 - 3 } & Very and fairly true \\
\hline $\begin{array}{l}\text { It's easy to get information on } \\
\text { environmentally friendly } \\
\text { consumption in the settlement }\end{array}$ & 87 & 0 \\
$\begin{array}{l}\text { Environmentally friendly } \\
\text { consumption is an important topic } \\
\text { of conversation in the settlement } \\
\begin{array}{l}\text { Environmental topics are often on } \\
\text { the agenda in conversations with } \\
\text { my neighbours }\end{array}\end{array}$ & 29 & 2 \\
\hline
\end{tabular}

information on ecological issues. Respondents in the car-free settlement are more or less in complete agreement that it is easy to get information on ecological consumption in the settlement. Most of this information is provided by residents which are active in various initiatives (outside the settlement). Most residents are registered on the internal mailing list that works as an effective means to spread information to most of the neighbours. One third of the respondents in the car-free settlement think that environmentally friendly consumption is an important topic of conversation. After all, three out of ten respondents stated that environmental topics are often on the agenda in conversations with neighbours. The situation in the reference settlement is completely different. The neighbourhood is not seen as a source of environmentally relevant information at all (Table 12).

Table 13 - Correlations between settlement attributes, $\mathrm{CO}_{2}$ per capita, air travel, and car travel

\begin{tabular}{|c|c|c|c|}
\hline \multirow[t]{2}{*}{$\begin{array}{l}\text { Settlement } \\
\text { attributes }\end{array}$} & $\mathrm{CO}_{2}$ per capita $(\mathrm{t})$ & $\begin{array}{l}\text { Air travel } \\
(\mathrm{km})\end{array}$ & $\begin{array}{c}\text { Car travel } \\
(\mathrm{km})\end{array}$ \\
\hline & \multicolumn{3}{|c|}{ Kendall-Tau-b ${ }^{a}$} \\
\hline $\begin{array}{l}\text { Environmental } \\
\text { awareness }\end{array}$ & -.052 & -.150 & $.305\left(^{* *}\right)^{\mathrm{b}}$ \\
\hline Social control & .135 & .022 & $.180\left(^{*}\right)$ \\
\hline Identity & -.022 & -.069 & .129 \\
\hline Cohesion & $.177\left(^{*}\right)$ & -.006 & .159 \\
\hline Social contacts & $.207\left(^{* *}\right)$ & .006 & $.258\left(^{* *}\right)$ \\
\hline Information & .039 & -.105 & $.339\left(^{* *}\right)$ \\
\hline \multicolumn{4}{|c|}{$\begin{array}{l}\text { ** Correlation is significant at the } 0.01 \text { level ( } 2 \text {-tailed). } \\
\text { "Correlation is significant at the } 0.05 \text { level (2-tailed). } \\
\text { a Kendall-Tau-b is a correlation coefficient that works well with } \\
\text { ordinal levels of measurements (this is the case with the perceived } \\
\text { social conditions). It does not need a normal distribution and its fits } \\
\text { with small samples. In our case it measures the "strength of } \\
\text { relationship" between perceived social conditions in the settlement } \\
\text { (and other subjective items) and ecological behavior (air travel in km } \\
\text { and car travel in km). The value of Kendall-Tau-b lies between- } 1 \text { and } \\
\text { 1. The value } 1 \text { means that the agreement between the two rankings is } \\
\text { perfect. If the rankings are independent, the coefficient has value } 0 \text {. } \\
\text { b Please note that the questions were phrased in a way that a lower } \\
\text { value for the variable "environmental awareness" corresponds to a } \\
\text { higher level of actual awareness. The positive sign indicates that } \\
\text { the higher the awareness (i.e., the lower the value) the fewer } \\
\text { kilometers had been traveled by car. }\end{array}$} \\
\hline
\end{tabular}

6.5. Relationship between social factors and environmental impacts

The respondents describe their settlements in very different terms. The car-free settlement seems to be a kind of small village within the city: a village where people know each other, a place with a colourful social life and with plenty ecologically aware residents. In contrast to that description the reference settlement seems to be more typical for Vienna: It is a nice place to live but the neighbourhood is not dominant in any way. One can enjoy urban anonymity, if desired. But is there an empirical relationship between those diverse social conditions in the settlements and the environmental impacts of households? Table 13 indicates that there is in fact a correlation between the perception of the 'social life' in the settlement and the environmental impact; even if it is not the overall $\mathrm{CO}_{2}$ emission which could be explained by settlement attributes. There is a notable statistical relationship (indicated through a significance level of at least 0.05 ) between environmental awareness, social control in the neighbourhood, social contacts in the settlement, and the availability of ecological relevant information in the settlement and the car mileage per year. On the other hand, there is absolutely no correlation between those items and air travel.

The high empirical variance of $\mathrm{CO}_{2}$ emissions per capita in both samples is mainly a function of air travel (Pearsons

Table 14 - Correlations between individual attributes, $\mathrm{CO}_{2}$ per capita, air travel, and car travel capita $(\mathrm{t})$ travel travel $(\mathrm{km})$ $(\mathrm{km})$

\begin{tabular}{|c|c|c|c|}
\hline \multirow[b]{2}{*}{ Education (respondent only) } & \multicolumn{3}{|c|}{ Kendall-Tau-b } \\
\hline & -.008 & .060 & -.085 \\
\hline $\begin{array}{l}\text { I regularly read articles about } \\
\text { ecological issues in } \\
\text { newspapers and magazines }\end{array}$ & -.125 & -.088 & .081 \\
\hline $\begin{array}{l}\text { I am very interested to } \\
\text { watch reports on ecological } \\
\text { issues in TV and radio }\end{array}$ & -.022 & -.034 & .138 \\
\hline $\begin{array}{l}\text { Environmental consumption is } \\
\text { very important regarding } \\
\text { energy }\end{array}$ & .014 & .057 & .120 \\
\hline $\begin{array}{l}\text { Environmental consumption is } \\
\text { very important regarding travel } \\
\text { and mobility }\end{array}$ & $.194\left(\left(^{*}\right)\right.$ & .148 & $.343\left(^{* *}\right)$ \\
\hline $\begin{array}{l}\text { Environmental consumption } \\
\text { is very important regarding food }\end{array}$ & -.078 & -.049 & .045 \\
\hline $\begin{array}{l}\text { Environmental consumption is } \\
\text { very important regarding } \\
\text { waste }\end{array}$ & -.074 & -.081 & .045 \\
\hline $\begin{array}{l}\text { Many friends of mine are } \\
\text { interested in environmental } \\
\text { issues }\end{array}$ & .027 & -.070 & .121 \\
\hline $\begin{array}{l}\text { Many friends of mine do not own } \\
\text { a car }\end{array}$ & $.199\left(^{*}\right)$ & .089 & $.369\left(^{* *}\right)$ \\
\hline $\begin{array}{l}\text { Many friends of mine prefer } \\
\text { organic food }\end{array}$ & .074 & -.108 & .082 \\
\hline
\end{tabular}

${ }^{* *}$ Correlation is significant at the 0.01 level (2-tailed). *Correlation is significant at the 0.05 level (2-tailed). 
$r=.897)$. Households with high air travel mileage score high in $\mathrm{CO} 2$ emissions. It seems that air travel (measured in $\mathrm{km}$ per household) is not dependent on other (observed) variables. It is neither a factor of settlement attributes nor of individual attributes of the respondents. All in all, only few individual factors correlate with measured environmental behaviour. As Table 14 shows there is an empirical relationship between environmental awareness concerning travel and the actual car mileage per year. In addition, it seems that households with low car mileage have more friends who do not own a car as well. Other sociological variables, like education, level of information, or specific indicators of environmental awareness, show absolutely no correlation.

\section{Discussion}

Our main findings can be summarized as follows:

1. The car-free housing project has lower $\mathrm{CO}_{2}$ emissions, measured per household, per capita, or per $€$ spent, than the reference settlement. Both settlements have lower emissions than the Austrian average, which can be explained by the lower income and factors related to larger family size, the use of district heating, and lower mobility needs. Avoiding car use is the most important reason for reduced $\mathrm{CO}_{2}$ emissions, but the purchase of green electricity is also important. The emissions of a household in the carfree settlement connected to ground transportation and energy are less than half of those in the reference settlement.

2. There are higher levels of environmental concerns in the car-free settlement, and its residents seek information on environmental issues. They also have more social contacts and there is more cohesion in the car-free settlement. These factors seem to contribute to reduced car use, but only social cohesion and social contacts are significantly correlated with reduced per capita $\mathrm{CO}_{2}$ emissions. Environmental behaviour in general and the avoidance of car use in particular seem to be important issues of discussion. We conclude that this social climate tends to reinforce environmentally friendly behaviour.

3. The emissions connected to the remaining household purchases are substantial and in fact dominate the overall HEI of both settlements. For the Austrian average, household energy use and ground transportation account for nearly half of the total HEI, but these values are lower for residents of the reference settlement and probably for Vienna in general, both because of the heating infrastructure and denser housing and because of the higher importance of public transport for daily transport needs. The high importance of these items and the higher income in the car-free settlement explain why the difference in per capita $\mathrm{CO}_{2}$ emissions is only $7 \%$. This indicates that it is important to assess all household purchases, not only a selected few.

4. Air transport has the highest emissions intensity of all purchases assessed. For the car-free settlement, air transport is responsible for more than twice the $\mathrm{CO}_{2}$ emissions of ground transportation plus energy. The distances are slightly higher than in the reference settlement, but close to the average Austrian household. From the interviews and the survey, we have no indication that vacation destinations are subject to the environmental discussions in the car-free settlement. The results also show that there is no empirical correlation between income and air transport. Moreover, there is no indication that the money saved from not owning a car is systematically diverted to air travel.

5. It was our hypothesis that environmentally conscious consumption behaviour in the car-free settlement would extend to other areas of behaviour as well. We did not find a difference in the consumption of organic food, which was high in both settlements. For other types of behaviour, our survey was too coarse. We did not find satisfactory ways to identify differences in the consumption of food - an important category. We did not attempt to assess recycling behaviour, because it has relatively little impact on $\mathrm{CO}_{2}$ emissions. For the 'other' category, the input-output analysis treats fairly broad classes of goods as homogeneous commodities. The environmental differences between buying hand-made wooden toys and massproduced electronic toys cannot be distinguished - both have the same emissions coefficient per unit expenditure. The hypothesis could hence neither be confirmed nor falsified.

In the following, we would like to discuss the merit of our novel approach, as well as the lessons to be drawn for sustainable consumption.

Our approach allows for a calculation of total household environmental impact from evidence collected by a 1-hour interview and reference to utility bills. With that, HEI assessment can be developed into a routine assessment tool for environmental projects and policy, taking into account more than the specific aspects of a project and hence is able to quantify part of the rebound effect. We feel fairly confident about the emissions calculations for transport and energy, because we had access to utility bills and we judge the information we received on car mileage and holiday destinations to be reliable. Errors for individual households should not be larger than $+/-20 \%$, and errors for the settlement averages are correspondingly smaller.

Variations in the composition of other expenditure, from food to services and toys, are much more difficult to capture. The commodity groups in the input-output analysis probably mask significant differences in the emissions intensity of individual items. It is simply unknown whether systematic differences in consumer preferences of these items can indeed affect the overall HEI. Bottom-up calculations of different dishes (Carlsson-Kanyama et al., 2003), for example, show that there can be substantial differences. Whether these are also borne out in diets of real people is unclear. Analyses of consumer expenditure surveys using energy or emissions intensities derived from input-output analysis cannot identify significant differences in HEI apart from the factors of car ownership and house type which we have included (Hertwich, 2005c; Peters et al., 2006).

The study shows that the two settlements are indeed fairly similar. This was of course part of the study design. The aspect 
in which they differ is the car-free feature. Tenants in the carfree settlement show a higher level of environmental awareness, and this awareness is translated to ecologically sound travel behaviour regarding ground transport (extensive use of bicycles and public transport for daily needs), the purchase of green electricity, but not air transport.

A number of interesting results was derived from investigating the motivational and social aspects and differences between the two settlements. For example, the study shows a significant difference in the social cohesion between the two settlements. Some have argued that social interaction can lead to lifestyle satisfaction which can reduce the desire for consumption (Kempton, 1993). It could be that the innovative features of the car-free settlement, with much space and social institutions (e.g., a listserv) to interact, play an important role in contributing to satisfaction with the chosen lifestyle. The social cohesion can also contribute to social pressure and social reinforcement of ecological behaviour. These features, however, could also be a result of the genesis of the project and the self-selection of tenants, although both settlements are theme settlements and had the opportunity to influence the settlement characteristics.

\section{Conclusions}

This study indicates that the car-free housing project has indeed lower $\mathrm{CO}_{2}$ emissions, measured per household, per capita, or per $€$ spent, than the reference settlement. Both avoiding car use and purchasing green electricity are effective in reducing the respective $\mathrm{CO}_{2}$ emissions in the car-free settlement. The emissions saved from not using a car are higher than those from buying green electricity. The two settlements have lower emissions than the Austrian average, which can be explained by the lower income and factors related to larger family size, the use of district heating, and lower mobility needs. Due to the importance of air transport and of the residual expenditure categories estimated by the input-output analysis, the difference in $\mathrm{CO}_{2}$ emissions between the two settlements is small. More detailed data on nutrition and other expenditure would be needed to confirm that there is indeed no systematic difference in the remaining expenditure categories.

Moving to the car-free settlement is not the main reason that people do not use a car anymore. Many residents have decided to live without a car long before they moved to the carfree settlement. Nevertheless, the issue 'car-use' in the carfree settlement is still a very important conversational topic in the settlement. This contributes to the stabilization of the carfree habit of the tenants. It seems that residents in the car-free settlement have changed their daily mobility routines permanently. Most of the daily mobility needs are covered by public transport and by bicycle. The ecologically conscious microculture in the car-free settlement helps to reproduce and stabilize these habits on a daily basis.

What we can learn from this investigation for the stabilization of more sustainable consumption patterns is that both factors social climate and infrastructure are important for facilitating behavioural change. In addition, the growth of air travel can easily offset gains from reduced car use. The results presented here underestimate the relative impact of air transport on climate change, since it neglects the important effects of water emissions at high altitudes (Royal Commission on Environmental Pollution, 2002). Other studies have highlighted the contribution of air transport to the environmental impact of transportation (Norland et al., 2005).

We have demonstrated that the sustainability of consumption patterns of specific populations can be studied without administering a full-scale consumer expenditure survey, and that interesting results can be obtained. A combination of lifecycle analysis and input-output analysis is required to study the emissions, and the approach should be informed by using available statistical information on household consumption patterns. Improving the sustainability of consumption patterns requires looking at the impact of the entire household consumption and investigating the underlying motivations and constraints to behaviour set by infrastructure and habits.

\section{Acknowledgements}

This research was funded by the Austrian National Bank and the Society of Non-Traditional Technology in Japan. The project was hosted at the International Institute for Applied Systems Analysis (IIASA) in Laxenburg, Austria. We would like to thank Atsushi Inaba (AIST, Tsukuba, Japan) for continuous support of our research efforts and Yuri Ermoliev and Leen Hordijk for graciously removing administrative hurdles. Two reviewers provided valuable feedback.

\section{R E F E R E N C E S}

Aasness, J., Biorn, E., Skjerpen, T., 1993. Engel functions, panel-data, and latent-variables. Econometrica 61 (6), 1395-1422.

Alberti, M., 1996. Measuring urban sustainability. Environmental Impact Assessment Review 16 (4-6), 381-424.

Barrell, J., Whitehouse, J., 2004. Home zones — an evolving approach to community streets. Proceedings of the Institution of Civil Engineers. Municipal Engineer 157 (4), 257-265.

Beer, T., Grant, T., Brown, R., Edgward, J., Nelson, P., Watson, H., Williams, D., 2000. Life-cycle emissions analysis of alternative fuels for heavy vehicles. CSIRO Atmospheric Research Report C/0411/1.1/F2. CSIRO, Aspendale, Australia.

Briceno, T., Stagl, S., 2006. The role of social processes for sustainable consumption. Journal of Cleaner Production 14 (17), 1541-1551.

Brohmann, R., Fritsche, U., Hartard, S., Schmied, M., Schmitt, C., Schoenfelder, C., Schuett, N., Roos, W., Stahl, H., Timpe, C., Wiegmann, K., 2002. Sustainable Districts on Urban Areas: Material Flow Analyses as an Instrument for Evaluation - End Report (German). Oeko-Institut, Darmstadt. (Institute for Applied Ecology e.V.).

Bullard III, C.W., Herendeen, R.A., 1975. Energy impact of consumption decisions. Proceedings of the IEEE 63, 484-493.

Carlsson-Kanyama, A., Ekstrom, M.P., Shanahan, H., 2003. Food and life cycle energy inputs: consequences of diet and ways to increase efficiency. Ecological Economics 44 (2-3), 293-307.

Cervero, R., 2003. City carshare - first-year travel demand impacts. Transportation Finance, Economics and Economic Development, pp. 159-166. 
Eurostat, 2001. Nameas for air emissions - results of pilot studies. Office for Official Publications of the European Communities, Luxembourg.

Frischknecht, R., 2004. Ecoinvent, v.1.1. Eco-Invent Centre, Zürich.

Fritsche, U.R., 2002. Nachhaltige stadtteile-die rolle des warenkorbs der konsumenten. In: Scherhorn, G., Weber, C. (Eds.), Nachhaltiger konsum: Auf dem weg zur gesellschaftlichen verankerung. ökonom verlag, Munich.

Glotz-Richter, M., 1995. Living without a car. World Transport Policy and Practice 1 (1), 45-47.

Gutmann, R., Havel, M., 2000. Post-occupancy survey of the car-free housing project in Wien-Floridsdorf (in german). Vienna.

Haas, W., Hertwich, E.G., Hubacek, K., Korytarova, K., Ornetzeder, M., Weisz, H., 2005. The environmental impacts of consumption: research methods and driving forces. IIASA Interim Report 05/ 027. International Institute for Applied Systems Analysis, Laxenburg, Austria.

Hanssen, O.J., 1998. Environmental impacts of product systems in a life cycle perspective: a survey of five product types based on life cycle assessment studies. Journal of Cleaner Production 6, 299-311.

Herendeen, R.A., 1978. Total energy cost of household consumption in Norway, 1973. Energy 3, 615-630.

Herendeen, R.A., Tanaka, J., 1976. Energy cost of living. Energy 1, 165-178.

Hertwich, E.G., 2005a. Consumption and the rebound effect: an industrial ecology perspective. Journal of Industrial Ecology 9 (1-2), 85-98.

Hertwich, E.G., 2005b. Consumption and industrial ecology. Journal of Industrial Ecology 9 (1-2), 1-6.

Hertwich, E.G., 2005c. Lifecycle approaches to sustainable consumption: a critical review. Environmental Science and Technology 39 (13), 4673-4684.

Jackson, T. (Ed.), 2006. The Earthscan Reader on Sustainable Consumption. Earthscan, London.

Kempton, W., 1993. Will public environmental concern lead to action on global warming. Annual Review of Energy and the Environment 18, 217-245.

Klotz, J., 2002. Verbrauchsausgaben-sozialstatistische ergebnisse der konsumerhebung+ cd rom. Statistics Austria, Vienna.

Kolleritsch, E., 2004. Input-output Tables 2000. Statistics Austria, Vienna.

Kronsteiner-Mann, C., Schachl, T., 2006. Privater Konsum-Vergleich der Ergebnisse der Konsumerhebung 2004/2005 mit den volkswirtschaftlichen Gesamtrechnungen 2005. Statistische Nachrichten 2006 (11), 1069-1077.

Lenzen, M., 2001. A generalised input-output multiplier calculus for Australia. Economic Systems Research 13 (1), 65-92.

Lenzen, M., Dey, C., Foran, B., 2004. Energy requirements of Sydney households. Ecological Economics 49 (3), 375-399.

Lenzen, M., Wier, M., Cohen, C., Hayami, H., Pachauri, S., Schaeffer, R., 2006. A comparative multivariate analysis of household energy requirements in Australia, Brazil, Denmark, India and Japan. Energy 31 (2-3), 181-207.

Loose, W., Mohr, M., Nobis, C., 2006. Assessment of the future development of car sharing in Germany and related opportunities. Transport Reviews 26 (3), 365-382.

MA5, 2006. Statistical data - Vienna by district Vienna City Government. http://www.wien.gv.at/statistik/daten/ bezirksdaten html2006accessed 27.10.2006.

Malinvaud, E., 1980. Statistical Methods of Econometrics. North-Holland, Amsterdam.

Moll, H.C., Noorman, K.J., Kok, R., Engström, R., Throne-Holst, H. Clark, C., 2005. Bringing about more sustainable consumption patterns: analyzing and evaluating the household metabolism in European countries and cities. Journal of Industrial Ecology 9 (1-2), 259-276.

Mont, O., 2004. Institutionalisation of sustainable consumption patterns based on shared use. Ecological Economics 50 (1-2), 135-153.
Munksgaard, J., Pedersen, K.A., Wier, M., 2000. Impact of household consumption on $\mathrm{CO} 2$ emissions. Energy Economics 22 (4), 423-440.

Nijdam, D.S., Wilting, H.C., Goedkoop, M.J., Madsen, J., 2005. Environmental load from Dutch private consumption: how much damage takes place abroad? Journal of Industrial Ecology 9 (1-2), 147-168.

Nobis, C., 2003. The impact of car-free housing districts on mobility behaviour - case study. In: Beriatos, E., Brebbia, C.A., Coccossis, H., Kungolos, A. (Eds.), Sustainable Planning \& Development. WIT Press, Southampton, Boston.

Norland, I.T., Holden, E., Lafferty, W.M., 2005. Consumption of energy and transport in urban households: the role of urban planning vs. 'green consumerism' in promoting sustainable consumption. In: Hertwich, E.G., Briceno, T., Hofstetter, P., Inaba, A. (Eds.), Sustainable Consumption: The Contribution of Research, 2005/1. Norwegian University of Science and Technology, Trondheim.

Peters, G., Hertwich, E.G., 2004. Production Factors and Pollution Embodied in Trade: Theoretical Development. WP 2004/5. Norwegian University of Science and Technology, Trondheim. Industrial Ecology Program.

Peters, G.P., Hertwich, E.G., 2006. The importance of import for household environmental impacts. Journal of Industrial Ecology 10 (3), 89-110.

Peters, G.P., Aasness, J., Holck-Steen, N., Hertwich, E.G., 2006. Environmental impacts and household characteristics: an econometric analysis of Norway 1999-2001. Proceedings, Sustainable Consumption Research Exchange, Wuppertal.

Preisendörfer, P., 2001. Sozialprofil und Lebenslage von Haushalten ohne Auto. Kölner Zeitschrift für Soziologie und Sozialpsychologie 53 (4), 734-750.

Prettenthaler, F.E., Steininger, K.W., 1999. From ownership to service use lifestyle: the potential of car sharing. Ecological Economics 28 (3), 443-453.

Priemus, H., 2005. How to make housing sustainable? The Dutch experience. Environment and Planning. B, Planning and Design 32, 5-19.

Ravetz, J., 2000. Integrated assessment for sustainability appraisal in cities and regions. Environmental Impact Assessment Review 20 (1), 31-64.

Royal Commission on Environmental Pollution, 2002. The Environmental Effect of Civil Aircraft in Flight. Royal Commission on Environmental Pollution, London.

Scheurer, J., 2001. Urban Ecology, Innovations in Housing Policy and the Future of Cities: Towards Sustainability in Neighbourhood Communities. Murdoch University, Perth, Australia.

Schweimer, G.W., Levin, M., 1999. Sachbilanz des Golf A4. Mit Bilanzplänen und Ergebnistabellen. Volkswagen, Wolfsburg. Z 99.519 .501 .00

Stokes, D., Lindsay, A., Marinopoulos, J., Treloar, A., Wescott, G., 1994. Household carbon-dioxide production in relation to the greenhouse-effect. Journal of Environmental Management 40 (3), 197-211.

Tukker, A., Jansen, B., 2006. Environment impacts of products - a detailed review of studies. Journal of Industrial Ecology 10 (3), 159-182.

Udo de Haes, H.A., Jolliet, O., Finnveden, G., Goedkoop, M., Hauschild, M., Hertwich, E.G., Hofstetter, P., Klöpffer, W. Krewitt, W., Lindeijer, E.W., Mueller-Wenk, R., Olson, S.I., Pennington, D.W., Potting, J., Steen, B., 2002. Life Cycle Impact Assessment: Striving Towards Best Practice. Society of Environmental Toxicology and Chemistry, Pensacola. United Nations General Assembly, 1992. Agenda 21. United Nations Division for Sustainable Development, Rio de Jainero.

United Nations General Assembly, 2002. World Summit on Sustainable Development: Plan of Implementation. United Nations Division for Sustainable Development, Johannesburg. 
Vringer, K., Blok, K., 1995. The direct and indirect energy requirements of households in the Netherlands. Energy Policy 23 (10), 893-910.

Wallisch, A., 2004. Personal Communication.

Wiener Linien, 2004. Alles über uns: Betriebsangaben 2003 Wiener Linien.

Wier, M., Lenzen, M., Munksgaard, J., Smed, S., 2001. Effects of

household consumption patterns on $\mathrm{CO} 2$ requirements. Economic Systems Research 13 (3), 259-274.
Wright, C., Curtis, B., 2005. Reshaping the motor car. Transport Policy 12 (1), 11-22.

Zacharias, J., 2003. The search for sustainable transport in a developing city - the case of Tianjin. International Development Planning Review 25 (3), 283-299. 


\title{
An integrated assessment of options for rural wastewater management in Austria
}

\author{
M. Starkl*, M. Ornetzeder ${ }^{\star *}$, E. Binner*, P. Holubar ${ }^{\star \star *}$, M. Pollak ${ }^{\star \star \star *}$, M. Dorninger ${ }^{\star \star \star * *}$, \\ F. Mascher ${ }^{\star \star \star \star \star *}$, M. Fuerhacker ${ }^{\star}$ and R. Haberl* \\ *Department for Water-Atmosphere-Environment, University of Natural Resources and Applied Life \\ Sciences, Vienna, Austria, Muthgasse 18, 1190 Vienna, Austria (E-mail: markus.starkl@boku.ac.at) \\ ${ }^{\star *}$ Centre for Social Innovation (now: Austrian Academy of Sciences - ITA), Vienna, Austria \\ ***Department for Biotechnology, University of Natural Resources and Applied Life Sciences, Vienna, Austria \\ ****wpa consulting engineers, Vienna, Austria \\ ${ }^{\star \star \star \star \star}$ Department of Sustainable Agricultural Systems, University of Natural Resources and Applied Life \\ Sciences, Vienna, Austria

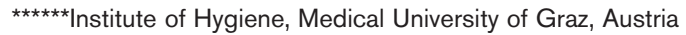

\begin{abstract}
This paper reports a recently finished, interdisciplinary project on rural wastewater management in Austria. The objective of the project was to study alternative wastewater management options based on separation of the wastewater into its constituent parts, and to compare them with conventional ones. Thereby, a feasibility study of both conventional and alternative options for wastewater management in six model regions was carried out. Life cycle costs and social acceptance were analysed by using a case study-based assessment approach. However, hygienic and environmental risks were evaluated on a more general level. In order to complement the findings, a survey on urine separation system users in the Solar City of Linz was conducted. Based on these assessments and empirical findings, the paper concludes that options using a full separation of all wastewater fractions should be considered with care. Options based on a separation of only grey water and black water or in the liquid/solid phase can offer ecological and financial advantages over conventional options. Further, options combining wastewater management and regional biogas plants were identified as an interesting solution. However, legal constraints restrict this option currently.
\end{abstract}

Keywords Assessment; case studies; integrated assessment; options; risks; wastewater management

\section{Introduction}

In Austria, about $10-15 \%$ of the population still does not have an adequate wastewater management system. For instance, in the province of Lower Austria about 200,000 inhabitants are still connected to cesspits or simple mechanical treatment systems. Furnishing these rural communities with conventional, centralised technologies would create high costs. As urban water management is subsidised by the federal government, these costs are of great political concern. For instance, the Austrian Kommunalkredit AG (which manages the funds for urban water management on behalf of the Ministry for Agriculture, Forestry, Environment and Water Management) spends about 250,000 EUR/ year on subsidies for urban water management. Further, the highest subsidies are available for areas with a low connection density (the top funding rate is currently $70 \%$ of investment costs). Moreover, in recent years, the traditional combined flow options for wastewater management have been criticised by several authors (e.g. Larsen and Gujer, 1996; Otterpohl et al., 1999; Wilderer and Schreff, 2000). These authors, among many others, argue that the traditional method of sanitation does not reuse the nutrients which wastewater contains, and that the invested capital is tied up in infrastructure (sewerage

doi: $10.2166 /$ wst.2007.562 
system, pumping stations, wastewater treatment plants (WWTP)), which is inflexible and designed for the maximum theoretical wastewater flow.

In order to overcome these weaknesses, alternative technologies based on the separation of the wastewater into its constituent parts, grey water and black water, where black water can further be separated into yellow water (urine) and brown water (faeces and flushing water), are proposed.

Traditionally, farmers in several Austrian provinces prefer to apply their domestic wastewater together with manure on their agricultural lands. However, inhabitants of rural communities who are not farmers need to collect their wastewater in tight tanks (septic tanks) and to arrange transport to a wastewater treatment plant, which causes high costs. Hence, the question arises, if synergies between agriculture and wastewater management would allow for more efficient forms of wastewater management for both farmers and non-farmers. Further, a better cooperation between solid waste management and wastewater management may offer advantages. For instance, composting of biogenic material and use of the compost in agriculture is a frequently applied practice in rural communities. This paper reports about the results of the project "Applied strategies towards sustainable sanitation (SUS-SAN)", which was commissioned by the Ministry for Agriculture, Forestry, Environment and Water Management, and seven out of nine Austrian provinces (Starkl et al., 2005). This project analysed potential synergies between wastewater management on the one hand, and agriculture and solid waste management on the other.

\section{Goal and methodological approach}

The philosophy of the project is illustrated in Figure 1. It is assumed that centralised options are the first choice to be looked at (as at the time these systems were built, their design loads were usually based on the later connection of all rural areas). Only if an economic connection to an existing centralised system is not possible (and legally not mandatory), do alternative options need to be considered. Thereby, SUS-SAN looked at options which separate the wastewater into its constituent parts, grey water and black water, where black water can further be separated into yellow water (urine) and brown water (faeces and flushing water). The idea is that these fractions can locally be treated and/or recycled more cost efficiently. However, such a concept is only acceptable if the problems of wastewater management are not shifted to agriculture or solid waste management, but that real synergies can be used between these sectors. A prerequisite for using synergies with agriculture and solid waste management is that the concentrated wastewater fractions (black water, brown water, urine) on the one hand cause benefits, and on the other, do not cause harm, to the cooperating sectors. The benefit is assessed in economic terms. Harm could be caused by the pollutants in the fractions to be recycled.

Based on selected case studies, an integrated assessment of both conventional and alternative options was carried out, following a more policy-oriented approach as outlined, e.g., in Starkl et al. (2005). The integrated assessment covered economic, social, hygienic and environmental risk-based aspects. Further, an analysis of the relevant legal material was carried out in order to assess any legal constraints in applying alternative options. The assessment of costs was carried out as a part of the feasibility study for the case study areas, and the social assessments were conducted with the inhabitants in the case study communities. The assessment of hygienic and environmental risks was then based on more general considerations. Hygienic risks were assessed in a qualitative way for the conceptual wastewater management systems, taking into account measures for 


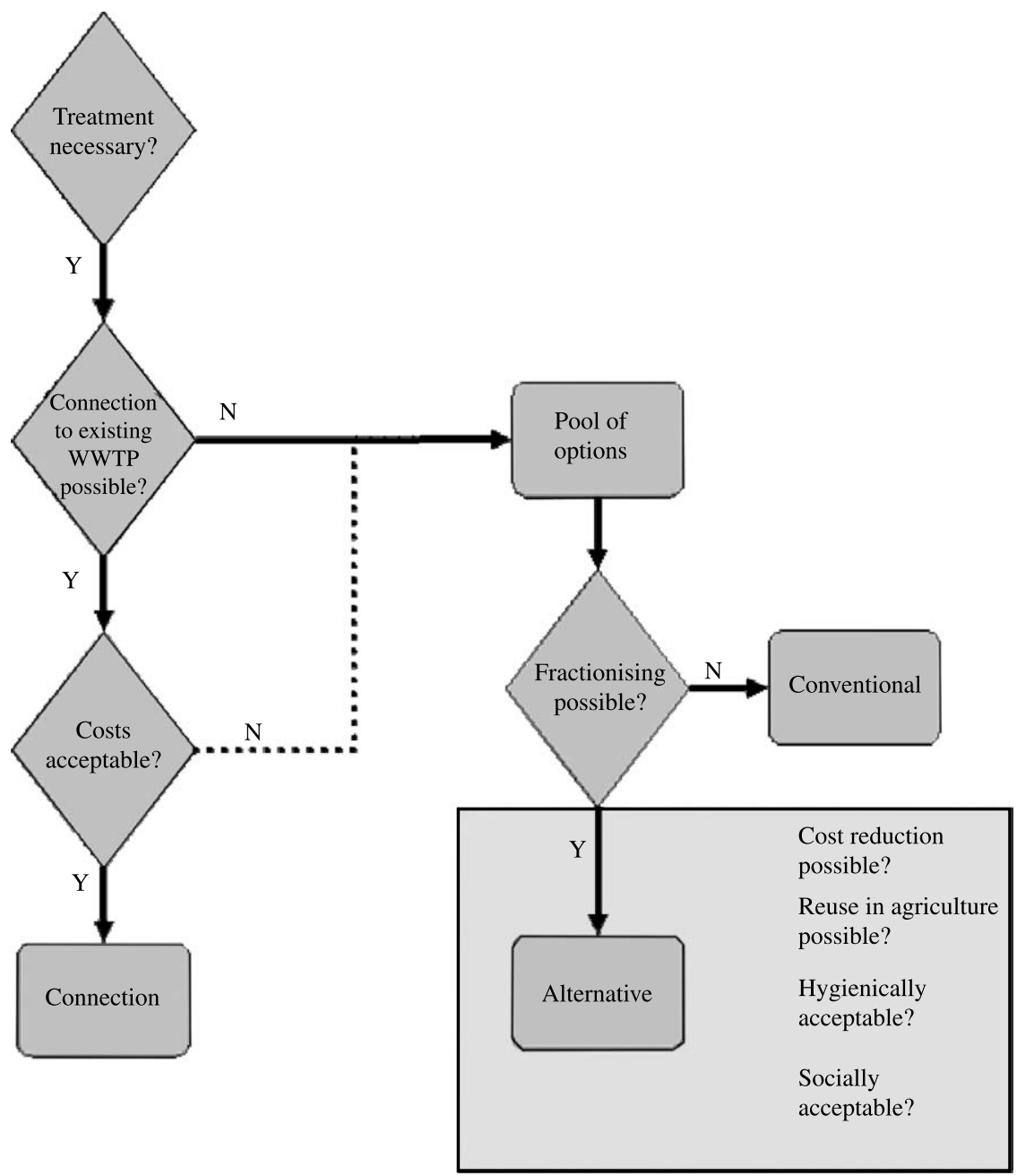

Figure 1 Decision tree for applying alternative concepts

composting systems). As a major environmental risk for applying urine in agriculture, the wash-out of micro-pollutants into the groundwater was considered. Based on a "worst case" and a "realistic case", a risk assessment was carried out.

\section{Pool of options and case studies}

The analysis of potential synergies between wastewater management on the one hand, and agriculture and solid waste management on the other, resulted in the following additional options for wastewater management.

\section{Treatment of fractions}

- Co-treatment of black water in an existing regional biogas plant. It is assumed that the small quantities of domestic black water generated in rural communities have no adverse impact on a regional biogas plant. In the case studies such regional biogas plants were identified and costs of such a co-treatment were calculated.

- Separating the wastewater into solid and liquid phases, such as the STEP/STEG system of the US-based company Orenco (this is a system where only the filtered effluent of a septic tank is transported through a pipe to a treatment plant, and 
the remaining sludge needs to be removed once every few years), or alternatively a "separator system" as e.g. produced by the Swedish-based company Aquatron (this has the shape of a cyclone in which the solid phase is separated from the liquid phase through gravity).

- Treatment of the black water in an aerobic baffled tank reactor with a subsequent soil filter.

- Collection of the brown water in a "Rottesack" and composting of the resulting substrate.

- Application of composting toilets.

- Collection of dewatered wastewater and composting.

For composting two systems were considered: in-house (or in garden) composting carried out by the house owner, and external composting in a professional composting plant.

Recycling of the fractions

- Treatment/co-treatment in a biogas plant and using the resulting substrate in agriculture

- Treatment/co-treatment in a composting plant (in-house composting or external composting) and using the compost in agriculture.

- Direct application of the wastewater or its fractions in agriculture.

- Direct application of urine in agriculture.

- Mixing of urine with manure and application in agriculture.

- Collection of grey water and using it for diluting manure or treatment in a constructed wetland.

The requirements for treatment of wastewater in the case studies are based on the Austrian Emission Standards for communal wastewater. The emission standards are more stringent than the official European Union standards, and demand effluent values of $25 \mathrm{mg}$ BOD plus nitrification $\left(10 \mathrm{mg} / \mathrm{L} \mathrm{NH}_{4}\right)$ for treatment plants below 500 PE. This case is referred to in the following part as Case 1. In addition, for seasonally dry water courses, higher emission standards have to be followed. However, there are no prescribed standards for this. For each case, the responsible local competent authority prescribes an appropriate standard, based on an analysis of the concrete situation. This case is referred to as Case 2.

In order to evaluate the costs and social acceptance of the different options, six case studies in three Austrian provinces were selected. A case study was a smaller area of a rural municipality (existing communities ranging from 10 to $87 \mathrm{PE}$ ), which up to now have only had cesspits (which are not state of the art according to the legislation) and hence need to improve their existing system. A conceptual feasibility study as well as a dynamic life cost calculation of all available options was carried out. Then, the results were discussed with the future users and a social analysis was carried out (this part was only carried out in three of the six case studies). Together with the conventional options, the project basically distinguished between two groups of options.

Group A (conventional options) comprises three systems: centralised (A1) or decentralised (A2) treatment plants and cesspits (A3). The alternative options (Group B) are further classified according to the separated wastewater fractions: black and grey water (B1), only urine (B2), all three fractions grey, yellow and brown water (B3) or only a separation into the solid and liquid phase of the wastewater (B4). In addition, for the above-mentioned Case 2, based on informal discussion with the responsible local competent authority, it was assumed that treating the full wastewater (Group A1) or the mixture of black and grey water (Group B2), with either a technical-biological treatment plant followed by a constructed wetland or sand filter, or a membrane bioreactor (MBR), 
would allow the effluent to comply with Case 2. For the treatment of the other fractions assumptions had to be made, owing to a lack of experience with such plants. For grey water purification, constructed wetlands and trickling filters were considered. As it contains less than $50 \%$ of the BOD, $\mathrm{P}$ and $\mathrm{N}$, it was assumed that the treatment plants can be designed $50 \%$ smaller than for conventional wastewater treatment. Wastewater without urine contains $80 \%$ less nitrogen; therefore, cheaper anaerobic treatment plants could be applied. An anaerobic baffled reactor (ABR) followed by a soil filter was considered. For Case 2 it was assumed that a conventional treatment plant followed by a sand filter (instead of a more expensive constructed wetland as above) is sufficient. Some options generate coarsely filtrated wastewater which is then being mixed with the grey water. Here it was assumed that the new mixture needs a treatment plant which can be designed about two-fifths smaller than a conventional wastewater treatment plant.

\section{Results and discussion}

\section{Cost assessment}

The considered costs encompass investment and reinvestment costs, costs for operation and maintenance, as well as costs for transport and disposal of final substrates (e.g. sludge, compost, etc.). The cost calculation used the net present value method, following the German LAWA guidelines (LAWA 2005). The time frame is 50 years.

In order to assess the robustness of the results against cost uncertainties, in addition a Monte Carlo simulation of the costs was carried out. Based on experience with cost uncertainties from real projects, this simulation used four influencing factors:

$q$ : costs of sewers and pumping stations;

$r$ : costs of treatment plants and storage tanks;

$s$ : costs of transport;

$t$ : costs for disposal of sludge in wastewater treatment plants.

These factors have been set according to actual experiences of cost uncertainties in practice at the following values: $q$ : $0.5-1.5 ; r: 0.75-1.25 ; s: 0.95-1.05 ; t: 0.5-1.5$. Then, 1,000 simulations were carried out which showed if the ranking of the options would change within these variations.

The cost calculations in all case studies show advantages for the alternative options. On average for all case studies, the cheapest alternative option is about $25 \%$ cheaper than the cheapest conventional option. In particular, the following alternative options can reduce costs. Installation of urine sorting toilets reduces the flush water considerably which results in less cost for emptying the septic tanks (this applies for Group A2 and B1). Application of a STEG/STEP system can reduce the costs for the sewer considerably, but this depends on regional characteristics (e.g. in one Austrian province the standardised unit costs for sewers are almost independent from the sewer size up to $200 \mathrm{~mm}$ ). Concepts based on tight cesspits out of Group A2 (which were often among the preferred options), are - if transport of the sewerage is foreseen to a WWTP - considerably more expensive. This option is only competitive if local farmers directly use the sewage sludge in agriculture (which is allowed up to a certain quantity in some provinces). Options based on upgrading of existing cesspits or septic tanks to a small-scale sequencing batch reactor or membrane bioreactor (producers offer special packages for such an upgrade) also proved to be not very cost-effective for the considered case studies.

The separation of urine (Group B2) or the separation of all wastewater fractions (Group B3) did not show any economic advantages. Only the application of composting toilets with garden composting (an option within Group B3) was an economically 
advantageous option in one case study for a single house (where the direct application of raw wastewater on agricultural soils was not permissible).

\section{Social analysis}

Social acceptance is of major importance for the diffusion and use of new technological options. According to Endruweit and Trommsdorff (2002) social acceptance is a positive reaction regarding the implementation of technical innovations. The evaluation of social acceptance of new wastewater management options within the project was designed to produce relevant information for both, the further technological development in this field as well as to support the decision-making processes in the case study municipalities. In order to get qualitative information on several new technological options we decided to carry out focus group discussions on location with concerned residents. Based on the "pool of options" for each case study the most appropriate options have been selected and presented to focus groups. All directly concerned homeowners have been invited by the municipalities to attend the presentation. The focus groups in our cases were comprised of 12 to 15 participants, which means that most of the concerned population was involved. Each focus group discussion was organised in a similar way. It started with general information on the research project, followed by a presentation of possible wastewater options for the planning area. After these presentations by project staff members the audience could raise questions that were followed by discussions on the presented technical options. Finally, a concluding assessment of options was gathered by means of a written questionnaire. In order to complement and verify the results of these focus group discussions, a survey on user experiences in a new development area of the city of Linz, where about 90 flats are equipped with urine sorting toilets and the tenants had about 1 year operational experience with such systems, was carried out.

Focus group members in all three cases have been very interested in alternative wastewater technology. Most of the presented alternative options are ranked much higher than centralized sewer systems. On a more general level, we can conclude that new options are attractive to the concerned population, if they are similar to well-known technology (e.g. septic tank solutions are similar to existing cesspits); they are positively described by experts and major problems did not arise during the discussion (which leads to methodical problems); and the implementation is supported by subsidies and scientifically monitored.

Technological options which demand behavioural changes - in our case urine-separating toilets or compost toilets - do not find much favour. The acceptance of these two options is rather small, even if they result in lower overall costs. Compost toilets have been on the market for many years but are hardly in use. With regard to this situation evaluation knowledge is also very limited. The results of focus group discussions in our project reveal a similar picture. Compost toilets are not an option. Participants argued that this solution needs additional space in the cellar (which often is not available), that there is a much higher maintenance effort (compared with conventional toilets), and finally, people think that compost toilets would cause a bad smell. Only very few participants would be interested in using self-produced compost in their own garden.

Urine-separating toilets are also perceived as a problematic solution. Focus group participants had been confronted with this technical option for the first time. After discussing various aspects of this technology nobody was willing to consider urine-separating toilets as a realistic option. Most important reasons against urine separation concern expected costs and additional constructional effort. Further, participants are in doubt about the assumed positive environmental effects. Results from our written survey on users of urine-separating toilets show a similar picture. The results of these studies were 
then verified with a social analysis of tenants of the Solar City in Linz, Austria, where around 90 flats in a new development area are furnished with urine-sorting toilets. Based on a year-long use-period every second user would prefer to change to a conventional toilet, if it was possible. Most users report cleaning problems and less comfort compared with conventional systems. Even satisfied users agree with this. Although most users are dissatisfied with their toilet model many of the respondents think that changes of the toilet design could help to improve the comfort and user friendliness. Our results also show that social acceptance of separating toilets is closely linked to the plausibility of the overall system. Users who believe that urine separation is an environmentally friendly measure are more likely to be satisfied with the toilet too. Another drawback is that compared with conventional toilets users of urine-separating toilets need to flush more often to clean the toilet, which leads to considerably higher use of water than expected.

The separation of grey and black water in the houses was recommended and discussed in two municipalities. This option was very attractive for future users in both cases (ranked first and second, respectively). Even participants with an agricultural background - a highly sceptical social group in our cases - took this option into consideration. The positive image of this option could be explained by three main reasons: first of all, this option is one of the most cost-effective solutions in the long term; second, this option could be easily combined with positively perceived constructed wetlands; and the third reason is that this kind of separation is partly in use in the area already (participants know users of this solution) and apparently it works quite well.

\section{Recycling of urine in agriculture}

Another question discussed in the project was: how relevant is the contribution of urineseparating systems to solve nutrient cycles in agriculture? This question was analysed from the perspective that agriculture should not be "misused" for disposal of any substrates, as mentioned earlier. In order to reach a real "recycling", two aspects need to be ensured: first, the substrate should have a benefit for agriculture and at the same time cause no harm to it. In order to answer if recycling of urine gives a benefit, a study on nutrient balances was carried out for the province of Lower Austria. It shows that if all households that do not yet have an adequate wastewater management system (about $180,000)$ were to be equipped with a urine-sorting system, only about $1.68 \%$ of the total used mineral fertilisers for $\mathrm{N}$ could be substituted. For $\mathrm{P}\left(\mathrm{P}_{2} \mathrm{O}_{5}\right)$ and $\mathrm{K}\left(\mathrm{K}_{2} \mathrm{O}\right)$ it would be even less: 0.9 and $1.1 \%$, respectively. First, this study has shown that on the one hand even large-scale implementation of urine-sorting systems would only provide marginal quantities of nutrients compared with the commercial fertilisers used; second, many areas in Austria have too many nutrients available; and third, the benefits of urine would only be marginal (around 5 EUR commercial value of $1 \mathrm{~m}^{3}$ of urine based on its nutrient composition). However, on the other hand, there would be no problem in applying the urine in agriculture (if appropriate measures for risk management are taken and it would be legally possible) as the quantities are very low.

Further, closing the nutrient cycle is often cited as an important benefit of systems allowing for a use of urine as a fertiliser. In the course of the project SUS-SAN, for two regions (out of four) in the province of Lower Austria, a more detailed nutrient balance was carried out. The aim of this exercise was to identify process chains in agriculture in order to allow a system-based connection of different agro-based technologies. Thereby, different agricultural development scenarios (e.g. increasing growing of energy plants, reducing green land, restriction of manure application, etc.) were considered (based on e.g. Buchgraber, 2004). As a result of this, the Seaborne process (www.seaborne.de), which can process sewage, manure and biogenic material, was identified as an interesting 
option. This process is producing a substrate which can be used as fertiliser, biogas, current, and other substrates which can be recycled.

\section{Environmental risks}

Owing to space limitations, the method and results of the risk assessment will be published elsewhere. Basically, a risk to the groundwater for wash out of urine from the soil was identified. Then, in view of hygienic risks, only in-garden composting (owing to a lack of monitoring of the sensitive composting process) and direct application of sewage or its fractions (apart from urine) on agricultural soils were considered to be unacceptable. All other options would be allowed for cost-effective risk management strategies (e.g. 6-month storage for urine). The costs for such measures were considered in the cost assessments.

\section{Conclusions}

The results of this project are based on the real constraints in Austria, and in particular on the results of the case study-based assessments. From the pool of conventional options (A), the case studies showed that both centralised (A1) and decentralised (A2) conventional options could be optimal solutions, depending on the local constraints. This is an interesting result insofar, as often in political discussions, centralised solutions are considered to be a priori inferior to decentralised solutions. Cesspits (A3), even if often among the most preferred options within communities, clearly are economically not competitive (if real O\&M costs are considered). Taking into account all aspects, out of the pool of alternative options, those of Group B1 without using a urine-sorting toilet and the STEG/STEP system out of Group B4 can be recommended. In particular, options from Group B1 have further potential for cost reduction, as the constructed wetlands used for treating the grey water could be designed in a cheaper way (e.g. by reducing the required area to about $1 \mathrm{~m}^{2} / \mathrm{PE}$ and using cheaper substrate). Additional research is necessary to demonstrate this. Although the use of composting toilets with in-garden composting could be cost-effective for households in remote areas, such solutions are hardly acceptable from a hygiene point of view (owing to a lack of monitoring of the sensitive composting process) and highly problematic regarding social acceptance. If such concepts were to be implemented, special scrutiny would need to be given to their approval and the monitoring process.

Another interesting option would be the direct processing of black water or brown water in a regional biogas plant. From a technical perspective up to $10 \%$ of brown water or black water would cause no problem to a regional biogas plant, but this option is not feasible within the existing regulations. Changing the legal situation here could have a considerable impact on wastewater management in rural areas. As a side result, the Seaborne process was identified as an interesting option. It would allow a system combining processing of sewage, manure and biogenic material. For the wastewater management sector this would mean that all existing infrastructure can be kept and that no separation is necessary, whereas a full potential of recycling of nutrients could be utilised. However, further research is needed to demonstrate this process.

Whatever option is selected, an important point is to ensure a successful operation for its full life time (which is up to 50 years). Taking into account the users' preferences and in particular their ability to operate the system (in the case that the operation is community based) seems to be key to a successful operation, in particular as the decision for a wastewater management system is essentially a collective decision for all 


\section{Acknowledgements}

The authors thank the Austrian Federal Ministry for Agriculture, Forestry, Environment and Water Management and the Provincial Governments for funding the project reported.

\section{References}

Buchgraber, K. (2004). Energetisch und stofflich nutzbare Biomasse aus dem österreichischen Grünland (Energetically and materially usable biomass from Austrian green land). The Research and Education Centre for Agriculture, 10th Alpine Expert Forum, Raumberg-Gumpenstein, 1-5.

Endruweit, G. and Trommsdorff, G. (eds) (2002). Wörterbuch der Soziologie (Dictionary of Sociology), Stuttgart, 2002.

Larsen, T.A. and Gujer, W. (1996). Separate management of anthropogenic nutrient solutions (human urine). Wat. Sci. Tech., 34(3-4), 87-94.

LAWA (2005). Leitlinien zur Durchführung dynamischer Kostenvergleichsrechnungen (guidelines for dynamic cost comparisons). Länderarbeitsgemeinschaft Wasser, Germany.

Otterpohl, R., Albold, A. and Oldenburg, M. (1999). Source control in urban sanitation and waste management: ten systems with reuse of resources. Wat. Sci. Tech., 39(5), 153-160.

Starkl, M., Brunner, N., Grasser, U., Moog, O., Stagl, S., Kärrman, E., Wimmer, J., Szewieczek, R. and Haberl, R. (2005). Analysis and evaluation of methodologies to assess technical urban water systems. Wat. Sci. Tech., 52(9), 43-51.

Starkl, M., Binner, E., Fürhacker, M., Holubar, P., Koeck, S., Lenz, K., Mascher, F., Ornetzeder, M., Pollak, M. and Haverl, R. (2005). Nachhaltige Strategien der Abwasserentsorgung im ländlichen Raum (Sustainable strategies for wastewater management in rural areas) - Final Report. Austrian Ministry of Agriculture, Forestry, Water Management and Environment, Vienna, 2005.

Wilderer, P.A. and Schreff, D. (2000). Decentralized and centralized wastewater management. A challenge for technology developers. Wat. Sci. Tech., 41(1), 1-8. 


\title{
Innovation networks in the refurbishment sector of Austria: promising approaches waiting for market success
}

\author{
Michael Ornetzeder* \\ Institute of Technology Assessment \\ Austrian Academy of Sciences \\ Strohgasse 45/5 \\ A-1030 Wien, Austria \\ Fax: ++43-1-71098 83 \\ E-mail: michael.ornetzeder@oeaw.ac.at \\ *Corresponding author
}

\section{Jürgen Suschek-Berger}

Inter-University Research Centre for Technology,

Work and Culture (IFZ)

Schlögelgasse 2

A-8010 Graz, Austria

Fax: ++43-316-8102 74

E-mail: suschek@ifz.tugraz.at

\begin{abstract}
In Austria, the highest potential for sustainable refurbishment is within the sector of single-family houses, which were built between 1945 and 1980. According to estimates, two-thirds of all the possible investments can be assigned to this category. However, there are only a few ambitious models on the supply side, which combine the efficient information and mobilisation of users with a comprehensive technical and ecological offer.

Two of these rare examples will be discussed in this paper. Both models have been operating at a local level for the promotion of sustainable refurbishment for several years. The studied examples are characterised by network structures that are constituted by heterogeneous local social players who aim at quality assurance to enable attractive offers for homeowners. Centrally coordinated units manage both network models. In addition to the management of networks, these units try to fulfil several other functions: public relations, training seminars, strategic development, advisory services for end users and the implementation of refurbishment measures.

Based on a comprehensive analysis and documentation of both models, we will present a critical evaluation of the network activities. It becomes clear that both examples face two major challenges: internally, to cover and productively manage a wide range of different functions in order to stimulate necessary innovations and externally, to influence the sociopolitical framework conditions to increase the demand for noticeable sustainable refurbishment.
\end{abstract}

Keywords: sustainable refurbishment; innovation networks; management of networks; evaluation. 
Reference to this paper should be made as follows: Ornetzeder, M. and Suschek-Berger, J. (2008) 'Innovation networks in the refurbishment sector of Austria: promising approaches waiting for market success', Int. J. Innovation and Sustainable Development, Vol. 3, Nos. 3/4, pp.285-300.

Biographical notes: Dr Michael Ornetzeder is a Senior Researcher at the Institute of Technology Assessment at the Austrian Academy of Sciences. $\mathrm{He}$ is a Lecturer at the University of Agriculture in Vienna and the University of Klagenfurt. He received his PhD from the University of Vienna in 1998. His doctoral thesis was on the social shaping of technology based on a case study on solar technology. In 2004, he was a Senior Researcher at the International Institute for Applied Systems Analysis (IIASA) in Laxenburg, Austria. His current main research interest is within technology studies, with a particular focus on the interrelations of social and technical innovations, shaping and diffusion processes, participation models, user involvement and sustainability. $\mathrm{He}$ is currently working on a national research project that applies lead user and constructive technology assessment approaches to sustainable innovation processes.

Jürgen Suschek-Berger is the Deputy Director of the Interuniversity Research Centre for Technology, Work and Culture (IFZ Department Manager of Energy and Climate) in Graz, Austria. He is a Lecturer at the Universities of Klagenfurt and Graz. He finished his studies in 1993. He is working as a Social Researcher in the fields of environmentally sound procurement and energy and climate. His current main research interests are technology research, strategies of diffusion for renewable energy sources, the management of ecological and social innovations, empirical research and user participation. For his work, he uses quantitative and qualitative methods of empirical research like surveys, interviews or focus groups. He is currently working on projects dealing with the socioeconomic aspects of sustainable buildings, sustainable product development and social networks.

\section{Introduction}

Habitation is, without a doubt, one of the key areas for sustainable development. The construction of residential buildings and necessary infrastructure requires land, energy and an enormous amount of building material. In modern societies, more than one-third of the overall energy consumption is used to serve heating and warm water needs. Along with traffic and industry, habitation is responsible for a considerable share of $\mathrm{CO}_{2}$ emissions.

Concerning the construction of new houses, major advances towards sustainability have been achieved in the last 20 years. In Austria, most new houses feature low energy standards. Moreover, we can see a trend of reducing land use by developing high-density areas (Rohracher and Ornetzeder, 2002). However, the highest ecological potential for improvement is found in the existing building stock.

According to a study on the refurbishment measures for residential buildings in Austria (Schuster et al., 2000), the largest reduction of energy needs could be achieved in private homes that were constructed in the period between 1945 and 1980. Approximately 700000 private houses should be considered for ecological improvements. 
In private households, refurbishment is still dominated by single-step procedures, a strategy oriented toward household finances, insufficient subsidy schemes and the urgency to carry out repairs promptly. In rural areas, the tradition is to do repairs in one's own house or in cooperation with semiprofessional craftsmen. These are conditions that considerably hinder the realisation of comprehensive and ecologically effective refurbishment concepts.

Problems can also be found on the supply side. Most construction companies lack the specific know-how to offer ecologically up-to-date refurbishment solutions. Therefore, locally based company networks that cooperate with different resources and skills are often seen as a solution to this problem.

Two examples of these rare networks have been analysed in a project within the framework of the Austrian research programme 'Building of Tomorrow' (Ornetzeder and Suschek-Berger, 2005). Both the selected cases focus on sustainable refurbishment in the private sector and have been active for several years in two different Austrian regions: the 'Öko-Modell im Alt- und Neubau' (Ecomodel) in the province of Tyrol and the network 'Traumhaus Althaus' (Old dream house) in the province of Vorarlberg. The results of our empirical research are based on 20 qualitative interviews with experts inside and outside the networks, a written survey on network customers and an extensive document analysis. The aim of this study was to understand how these initiatives work, discuss the options for improvement and establish similar initiatives in other regions.

In this paper, which is based on the results of the aforementioned project, we will give a short description of the studied networks, then compare both cases and discuss some of the key functions on a more general level. Then, the focus will be on the possibilities and limitations of networks to shape and stimulate innovation. Before going into the empirical details, we will refer briefly to the theoretical discussion on innovation networks.

\section{Innovation networks and sustainability}

The emergence of new forms of cooperation, located between the principles of 'market' and 'hierarchy', has not only been widely discussed in politics and the public in the last 10 to 15 years but, driven by empirical evidence, has gained importance in the social sciences as well and a number of theoretical concepts have been developed in order to describe and understand these new phenomena. Most concepts refer to social networks and clusters. Clusters are often studied from an economic perspective. The most important theoretical argument is that clusters have the potential to affect competition by increasing the productivity of the companies in the cluster, driving innovation and stimulating the new businesses in the field (Porter, 1980).

Social networks are also discussed in the context of sustainable development as a promising solution. Networks are seen as qualified institutions or new forms of governance to promote the normative objectives of sustainability. From this point of view, networks mobilise the potential for self-organisation, bring together social players who are otherwise separated by traditional institutions or help create a 'milieux innovateur'. Majer (2005) argued that sustainable development is not only a guiding vision, but is closely connected to the implementation of new governance structures such 
as social networks. In a similar way, Minsch (n.d.) stressed the importance of new forms of cooperation for sustainability, which could not succeed without a broad mobilisation of creative problem-solving potentials.

But what is a social network? How can we define this concept? Generally speaking, social networks are loosely coupled individual or organisational systems of action. They are characterised by a common purpose, the logic of communication and negotiation and minimal internal institutional structures. Network members cooperate on a voluntary basis because the positive effects are considered to be higher than the costs that are involved (Fürst, 2001).

Social capital (Coleman, 1988; Putnam, 1993) is considered to be one of the basic principles for interaction in networks. Social capital results from communication, discussions on professional knowledge and values and the willingness to cooperate. It relies on trust, which serves as a basis for the development of cooperation and mutual support.

Social networks operate with paradigmatic forms of governance much more than traditional institutions, which means that they try to influence social action by forming opinions. Paradigmatic governance can be used in networks because it is assumed that the recipients trust the sender. Recipients, as partners in networks, are open to advice (Fürst, 2001).

In our context, company networks with a common focus on innovation are of particular importance. Küppers and Pyka (2002) defined such innovation networks as the interaction processes between a set of heterogeneous players producing innovation at different geographical levels. Innovation networks are cooperative relationships aiming at the invention, development and successful implementation of products and processes. In our case studies, local networks in the building industry try to develop comprehensive offers for homeowners. The innovation is not a single product, but rather a combination of ecological advisory services, planning and the application of various new refurbishment technologies.

Why should companies join innovation networks? The most common argument refers to advantages in competition. Innovation networks are seen as a strategy for success, even under problematic conditions. Küppers (2002) argued that innovations are becoming increasingly more complex and, at the same time, a product has to fulfil the potential user's specific requirements. Innovations must not only function technologically and be economically viable, but also fit into the sociopolitical environment. Therefore, single companies alone are not able to summon up enough intellectual, social and material resources to be successful. Innovation networks could work as a medium through which material and symbolic resources are mobilised and combined (Perry, 1993). Through network interaction, the permanent processes of changing, searching and learning could be stimulated, helping improve the market position of the network partners (Hellmer et al., 1999). Moreover, innovation networks could reduce different kinds of uncertainties in the innovation process if the network partners' various competencies are successfully integrated (Küppers, 2002). In summary, it can be stated that from a theoretical perspective, social networks are considered powerful sources of innovation - at least, under specific conditions.

As empirical case studies show, in practical experience, ideal-type outcomes are seldom achieved. In a comprehensive German study, the authors concluded that the effects of innovation networks are marginal in comparison to the potentials of markets and hierarchy. This is particularly true for Small- and Medium-sized Enterprises (SMEs), 
a sector that is still characterised by distinctive competitiveness, which considerably hinders new forms of cooperation (Hellmer et al., 1999). The importance of regulatory and policy frameworks for the success of technical innovations - even when they have been produced in innovation networks - is demonstrated in a case study on combined heat and power technology in Europe (Weber, 2002). It seems that under real conditions, innovation networks are confronted with a number of internal and external challenges. In this paper, we will concentrate on those aspects that networks are able to control by themselves.

\section{Case studies}

The comprehensive ecologically effective refurbishment of the building stock is one of the key strategies to distinctly reduce $\mathrm{CO}_{2}$ emissions. While in the last years, this potential has been developed quite successfully for multifloor buildings in Austria - refurbishment projects are planned and organised by large housing companies - the situation in the private home sector is still problematic.

In order to stimulate innovation on the supply side, two network activities were started in the provinces of Vorarlberg and Tyrol. Although very close geographically, they have been developed completely independent of each other. Both networks aim to improve offers for private customers. Improvement means that homeowners who are planning to modernise their houses should be able to get up-to-date information on ecological refurbishment. The core idea of these consultations is to promote comprehensive refurbishment concepts, which are able to save energy and maximise the ecological effect. The implementation of single measures that show only little ecological effects and often result in additional repairs within a few years should be avoided. Both initiatives focus on private homeowners, which represent the largest market for building companies in these regions. Moreover, in both cases, the cooperation in local networks should improve the technical know-how and practical skills of the involved companies and promote joint refurbishment projects.

\subsection{Case study 1: Öko-Modell im Alt- und Neubau (Ecomodel) 3.1.1 Background}

The Tyrol-based network 'Eco Model for Old and New Buildings' (Ecomodel) started in 1997. The founder of the network was a grammar school professor with many years of experience with school projects that focused on energy issues. In those projects, pupils had the opportunity to act as energy advisers. They collected relevant data in their own household and, based on that information, they prepared tailor-made advice for energy-saving measures. Some tools and energy guidelines that were developed in the school context were used later in the Ecomodel network.

The main idea of the Ecomodel was to transfer the positive experiences of the school projects to a more professional basis in order to take effect. This became possible in a small rural Tyrolean region - the district of Reutte - because the concept appealed to some municipalities of this district. For those municipalities, the Ecomodel was part of a strategy to block plans for a hydropower station in this ecologically sensitive region. Instead of producing more electricity - which was the idea - the experts of the network 
should effectively detect potential energy savings in households and offer advice on how to deploy it. Eventually, the hydropower station was never realised, mainly due to the activities by local politicians and citizens' initiatives. Today, this part of Reutte is a nature protection area.

The Ecomodel started with a pool of around 20 local companies and institutions, most of them representatives of the construction sector and, therefore, interested in contracts with private homeowners, but a banking institution and a few municipalities were also involved. The aim was to cover the whole range of professionals necessary to accomplish comprehensive refurbishment projects. In the beginning, it was of decisive importance that the initiator was able to convince the potential members in person to become part of the network. Then, it was important that the setup and coordination of network activities were funded by European subsidies for the first three years. In the beginning, the activities were concentrated on retrofits and the dissemination of sustainable energy technology such as solar collectors or biomass heating systems.

In the year 2000, the Ecomodel spread to two other Tyrolean districts. As the EU funding phased out, a new institutional body was established in 2001. The private association, 'Network for Nature, Environment and Economy', took over the networking activities and initiated a comprehensive training course on green buildings, energy efficiency and renewable energy technology. In this context, the activities of the Ecomodel expanded to the planning and construction of new buildings. Around 20 people - the present energy advisers of the network and employees of network members, as well as interested individuals - attended this vocational training. As a result, the training helped improve the quality of the consulting activities. From the point of view of the newly established association, the organisation of the training was also important as a strategy to acquire public funding.

Along with the growth of network activities, conflicts with similar energy consultation centres arose. Consequently, one of the three network centres had to be closed shortly after its launch due to keen competition by the official energy consultants of the Tyrolean government.

Between 2001 and 2004, the activities of the Ecomodel shifted more and more toward consultation on new building development. It was not until the regional subsidy scheme for retrofits was improved that the demand for consulting grew again. In the last years, approximately one-third of the network activities have been connected to refurbishment projects. At present, the network consists of around 30 companies in two Tyrolean districts. Six company-independent experts offer a comprehensive range of consultation services. The activities are organised by two regional offices.

\subsubsection{Main aims and services}

The main aim of the Ecomodel is to promote environmentally sound practices in the construction sector. As in the beginning, when the focus was on energy issues and the refurbishment of private houses, today the activities cover all aspects of sustainable construction, as well as the development of new buildings.

The offered recommendations are designed for private homeowners who are either building a new house or retrofitting an existing building. Specially trained experts who work for the network on a freelance basis give the recommendations. Although most of these activities are financed by the members of the network, the given advice regarding technologies as well as companies is strictly neutral. As we know from our customer 
survey, the quality of this service of the Ecomodel has an excellent reputation. On the one hand, the given advice aims at ecologically comprehensive concepts that cover a wide range of aspects, not only energy issues. On the other hand, the customer with his or her needs and abilities is placed at the centre of the practiced philosophy and the offered advice is seen as a common learning process. The solutions are to be developed step by step. Although the experts try to promote 'green' solutions, all decisions are made together with the customer.

The advice is structured modularly. The first module is about the basic principles of sustainable construction and addresses the specific needs of the customers. This unit is given free of charge (financed by network members). The second module covers the development of a tailor-made energy concept. The third part is even more concrete and provides contract specifications. Furthermore, it is possible to task the experts of the Ecomodel with the execution of construction works and a quality inspection at the end. The most important technical know-how is summarised in a written booklet, which is available for free from local municipalities.

\subsubsection{Network structure and mode of operation}

Today, the Ecomodel network involves about 30 members. Most of them represent the local construction industry, but there are also two banking institutions and a few municipalities. The private association 'Network for Nature, Environment and Economy' serves as legal body of the Ecomodel. The membership and cooperation within the network is fixed by a written agreement to be confirmed yearly. To a great extent, the network is self-organised. Once a year, all of the relevant partners get together at the annual general meeting to discuss and decide the principal direction of the Ecomodel.

As provided in the agreement, the members of the Ecomodel commit to fostering the idea of sustainable construction, supporting the vocational trainings of employees and network experts, cooperating with the other members of the network in concrete projects and being a part of the networks' publicity campaigns. The membership fee is 1100 euros per year, without regard to the size of the company.

The members of the network are able to profit in several ways: through joint marketing activities, training opportunities for employees or getting in touch with potential customers at 'mini-fairs' organised by the Ecomodel centres. Moreover, the members of the network have direct access to the data of the people who make use of the Ecomodel's consultation services (advisers have to inform the customers at the beginning of every consultation and only when they agree is personal information used in this way). For most network members, acquiring access to new customers was the main motivation to join. The companies that had left the network after some years of experience mentioned the same reason - their expectations regarding new customers were not fulfilled. It seems to be obvious that outstanding consultation services do not directly result in corresponding contracts and project realisation.

\subsection{Case study 2: Traumhaus Althaus (Old dream house)}

\subsubsection{Background}

The network 'Traumhaus Althaus' was established in the year 2000 by the Energieinstitut Vorarlberg (Energy Institute of Vorarlberg) in the province of Vorarlberg. The Energy Institute is well known as the principal consulting and research institute 
in this province. Around 15 experts in the areas of building, industry and municipality conduct research and consultations. Most of the activities of this think tank are sponsored by public authorities.

The central motivation for the Old dream house initiative was to improve the know-how and practical skills in the construction industry regarding comprehensive refurbishment projects. While in the 1990s, the main focus was on the development of new buildings (and, as a consequence, the standards regarding energy efficiency and green materials improved tremendously), the situation regarding refurbishments lagged clearly behind. For the experts at the Energy Institute, it soon became clear that the existing building stock would represent a huge potential for ecological improvements. As the local government started to change the support programmes at the end of the 1990 s - shifting money from new developments to refurbishments - it became even more important to start a kind of qualification network for these specific tasks.

In the preparation phase, the Energy Institute conducted a survey in order to learn more about the needs and interests of homeowners. Together with an advertising agency, they prepared a public relations concept that includes the brand 'Old dream house', based on the idea that even an old building could be 'ideal as a dream' if it is modernised according to high (ecological) standards. As a next step, they launched a marketing campaign in order to inform the general public about the advantages of ecological refurbishments and the changed subsidy programmes. At the same time, the project team at the Energy Institute started to recruit members for the company network using personal contacts at local fairs, as well as a direct mail, covering more than 2000 addresses. Around 300 participants came to the kickoff meeting.

The Old dream house network started in January 2000 mainly as a platform for vocational training, with almost 150 institutional members. Quite similar to the concept of the Tyrolean Ecomodel, the idea here was also to cover a whole range of necessary professions. The long list of founder members included architects, builders, roofers, installers, electricians, solar energy experts and many more.

Within the first two years, the network management organised eight network days with around 40 presentations and more than 70 different workshops. Those activities were not only aimed at improving the knowledge of the company representatives; the network management also intended to provide as much space as possible for personal interaction in order to establish mutual trust. This was seen as a major precondition for doing joint contracts in the future.

Because of the huge number of members, it soon became clear that the organisation of those platform days would be a serious challenge for the Energy Institute. It also turned out that it would not be easy to create a programme that covers all the different needs of the participants.

After two years, the network members had to decide for the first time whether to continue their membership or leave the network. Surprisingly, a huge number of members left the network at this point. In most cases, the companies had the feeling that they had learned enough and, therefore, it would not be necessary to continue. In other cases, the companies quit their membership because they were no longer interested in keeping the high quality standards of the network. 
As a result of these experiences, the network management adapted the original concept. Quality regarding training as well as practical implementation at the construction site became even more important. The rules and methods to guarantee internal quality standards were reworked completely. Moreover, the membership fee was notably increased. In 2003, the network continued with around 60 companies.

\subsubsection{Main aims and services}

The main focus of network management is on know-how transfer and quality control. The network members should be able to carry out comprehensive refurbishment projects that meet high ecological standards. Therefore, refurbishment projects have to consider the following principles:

- maintain usable inventory

- reduce energy losses

- use raw materials sparingly and prefer renewable materials

- $\quad$ use recycled and recyclable materials

- heat with renewable forms of energy like biomass or solar

- consider the long service life of buildings (Energieinstitut Vorarlberg, 2003).

In order to meet those principles, refurbishment projects in most cases have to be as comprehensive as possible - it is not enough to renew the windows or the old heating system. For these purposes, two aspects seem to be of core importance. Firstly, specialists have to learn to think in a broader way (seeing the whole picture) and secondly, they need more competencies in cooperating with other specialists (coordinating the work at interfaces).

These two aspects are taken up repeatedly in the vocational training programme. As already mentioned, the programme is organised in the form of network days. Beside a broad range of technical seminars, company management issues are also covered. The quality of this offer is rated very high by members, even among those who left the network after the first two years.

Besides the training programme, the network organises consumer-oriented marketing activities. Private homeowners are regularly informed about the advantages of ecological refurbishments, the quality standards of the network and the available public subsidies for refurbishment projects. On these occasions, the management strives to establish the brand 'Old dream house' as a widely known and accepted high-quality label.

\subsubsection{Network structure and mode of operation}

In this case, the network management takes up a central position in form as well as in content. It has defined the rules and developed the guidelines. The management organises the training seminars and monitors the quality of the output. Most of the communication, even between single members, flows through the central management. The members are rather seen as customers than as active shapers of the network. Contrary to the first case study, the members of the Old dream house network are not in a position to influence the strategic orientation of the network. 
The network members have to pay a yearly fee (between 900 and 2100 euros) depending on the number of employees. They also have to abide by a special codex regarding technical and procedural rules. The codex covers the instructions for the customer relationship, a commitment to the concept of sustainability (with regard to construction/refurbishment) and some rules for cooperation within the network.

The most important element is vocational training. At least one employee of each network company has to be qualified as an energy and ecological building expert. These experts have to participate in additional training programmes and should spread know-how and skills within their own company. The management annually monitors the effectiveness of the training using questionnaires.

In Table 1, we try to compare both case studies. It turns out that there are some striking similarities (on a more general level), as well as some interesting differences (e.g., regarding mode of operation, some core competencies or the membership structure). We will refer to this overview in the discussion section.

Table 1 The common and different network features

\begin{tabular}{|c|c|c|}
\hline Common features & \multicolumn{2}{|l|}{ Short description } \\
\hline General goals & \multicolumn{2}{|c|}{ Implementation of comprehensive ecological retrofit innovations } \\
\hline & \multicolumn{2}{|l|}{ Focus on private homes } \\
\hline & \multicolumn{2}{|c|}{ Innovations through cooperation in local networks } \\
\hline Training focus & \multicolumn{2}{|c|}{ Technological and practical skills for energy-saving retrofit measures } \\
\hline Organisation & \multicolumn{2}{|c|}{ Strategic networks with limited membership (to be renewed annually) } \\
\hline & \multicolumn{2}{|c|}{$\begin{array}{l}\text { Cooperation with autonomous companies, with partly } \\
\text { overlapping interests }\end{array}$} \\
\hline & \multicolumn{2}{|l|}{ Strong management } \\
\hline Differences & Ecomodel & Old dream house \\
\hline Starting point & $\begin{array}{l}\text { Energy advice for private } \\
\text { households }\end{array}$ & $\begin{array}{l}\text { Know-how transfer to the } \\
\text { building industry }\end{array}$ \\
\hline Contact with customers & $\begin{array}{l}\text { Direct contact through } \\
\text { energy consultancy }\end{array}$ & Public relations \\
\hline $\begin{array}{l}\text { Core competence of the } \\
\text { network management }\end{array}$ & $\begin{array}{l}\text { Networking and energy } \\
\text { consultancy }\end{array}$ & $\begin{array}{l}\text { Research, energy consultancy, } \\
\text { education and training }\end{array}$ \\
\hline Size & About 30 network partners & $\begin{array}{l}\text { About } 60 \text { partners } \\
\text { (originally 160) }\end{array}$ \\
\hline Membership structure & Heterogeneous & Branch-specific \\
\hline Commitments & Informal & More formal (contract and codex) \\
\hline Financing & $\begin{array}{l}\text { Membership fees, earnings from } \\
\text { comprehensive consultancies, } \\
\text { project money }\end{array}$ & $\begin{array}{l}\text { Subsidies from the local } \\
\text { government, membership fees }\end{array}$ \\
\hline
\end{tabular}

\section{Analysis of the central functions}

In order to meet the self-assigned goals, the studied innovation networks must serve various functions. The network management has to coordinate strategic development and is responsible for the internal flow of information. Moreover, the management 
organises internal training seminars and supports communication with the customers (through consulting and/or public relations). All of these activities aim to develop and implement ecologically effective retrofit projects. In the following paragraphs, we will describe and analyse these main network functions in detail.

\subsection{Strategic development}

Dealing with strategic questions is of decisive importance for the development of innovation networks. In these cases, questions could refer to technical aspects ('How do we define ecological refurbishment?'), as well as the coordination of different tasks ('How could we combine information campaigns, consultation services, training seminars, etc., with an effective strategy?'). Strategic decisions should also guarantee good financial management and public relations resources.

In both cases, the management is mainly responsible for strategic network development. In the case of the Old dream house network, strategic decisions are discussed in a steering group that consists of company representatives and chaired by the responsible management project leader. For basic decisions, the main sponsor of the network activities, the government of Vorarlberg, must be consulted. In the Tyrolean case, the association 'Network for Nature, Environment and Economy' is concerned firstly with the development of strategies. However, the network's energy and building consultants - a core group of about five persons - are closely involved in all strategic discussions as well. After consulting this core group, the annual working programme is presented and discussed at a meeting with the network companies. In contrast to the situation in Vorarlberg, the strategic development of the Ecomodel network is not institutionally linked to the local government's housing department.

\subsection{Network management}

Network management includes the administration as well as support of network members, the exchange of information and the handling of financial and contractual concerns.

In the network 'Traumhaus Althaus', the management tasks are operated by the responsible project group at the Energy Institute of Vorarlberg. The activities are financed by governmental funds, as well as membership fees. In Tyrol, the network is divided into two independent regional networks, which are managed by separate offices. Due to a much smaller number of members in the Ecomodel, the office representatives are able to contact each member personally at least once a year. Although the management in both cases is very active, both networks are confronted with decreasing numbers of members.

\subsection{Internal qualification and training}

The network partners' internal qualification refers firstly to theoretical as well as practical know-how, which is necessary for implementing up-to-date ecological retrofits. In both cases, qualification training is organised by the management.

This aspect is of major importance in the Old dream house network. The network management has easy access to the professional and personal resources of the Energy Institute, which is complemented by external experts, if necessary. Qualification training 
is offered four days per year. Each network partner should attend at least two training days. In interviews, the participants unanimously report on the high quality of these training programmes. For many companies, the access to this kind of knowledge was one of their reasons for joining the network.

In the second case, internal qualification does not play such a major role. In fact, there is a training programme for companies, but it takes place only once a year.

In spite of the differences in the two cases, it appears difficult to offer attractive training programmes for a longer period of time due to the problems involved in designing 'one-size-fits-all' seminars in heterogeneous networks.

\subsection{Public relations}

Both network managements run public relations activities. These activities include information for the general public about the network activities, as well as the attempts to set up trademarks for the networks. In the case of the Ecomodel, which is more customer-oriented, the information aspect is of major importance. The network management tries to inform the homeowners by means of advertisements in local newspapers and other promotional material. Homeowners should recognise and make use of the range of network services. Establishing a brand or promoting network partners is of less importance in Tyrol.

With the Old dream house network, the main focus is on brand development. In the first two years, the management had launched several advertising campaigns throughout the province. The trademark 'Old dream house' was supposed to become well known in Vorarlberg. As the results of the customer survey show, this strategy did in fact lead to a larger amount of public awareness - compared to the Ecomodel in Tyrol - but the goal to establish 'Old dream house' as a quality label has not yet been accomplished. It is also obvious that only a small number of network members use the Old dream house promotional material; their own original corporate logo is of much greater relevance. As a consequence, the capability of the network's public relations activities to acquire new customers is very limited.

\subsection{Advice on energy use and green technology}

Consultancy for private homeowners is an integrated part of the network activities only in the Ecomodel network. Free initial consultations are financed by membership fees paid by all participating companies. In Vorarlberg, consultations are given by a group of experts sponsored by the local government. The Old dream house management is in contact with this consultancy group, but there is no direct link to the network activities.

In both provinces, the advising services have a very good reputation in public opinion. The given information is valuable in content and classified as neutral with respect to companies and products.

\subsection{Implementing refurbishment projects}

Both networks are only indirectly involved in refurbishment projects. Contractors are network companies or project-based network partner cooperations. 
Although many homeowners use advising services, the dissemination of comprehensive ecological retrofits is still extremely limited. Therefore, the cooperations between network members are more an exception than a rule. One of the central goals of the network activities - to push ahead with innovation in refurbishment projects - has not yet been achieved.

A long tradition in the construction sector is to form project-based cooperations with complementary trades. These cooperations are often based purely on mutual trust and stabilised by ongoing cooperations. Unfortunately, the studied networks have not stimulated project-based cooperations such as these so far.

The practical impact of the network activities on innovation is qualitative rather than quantitative, i.e., the networks' improved offers have not stimulated as many projects as expected, but the technical quality and the scope of single projects have improved considerably.

Table 2 gives an overview of the central functions of the studied networks and characterises these functions by main tasks.

Table 2 The central functions and related tasks in refurbishment networks

\begin{tabular}{ll}
\hline Functions & Tasks \\
\hline Strategic development & Formulation of technological guidelines on refurbishment quality standards \\
& Coordination of different substrategies (information campaigns, advice \\
& services, training seminars, etc.) \\
& Network setup and development \\
& Guarantee of financial resources (subsidies, fees, fund raising) \\
Network management & Administration of contracts \\
& Support and attendance of network members \\
& Supply and allocation of information \\
Qualification & Development of training seminars for network partners \\
and training & Quality assurance \\
Public relations & Training seminars for advisers (Ecomodel only) \\
& Ecological refurbishment fairs \\
& Production of promotional material \\
& Information campaigns, advertisements in local newspapers \\
& Trademark promotion \\
General advice (focus refurbishment) & Customised advisory service \\
(Ecomodel only) & Energy and refurbishment concepts \\
Implementation of & Monitoring \\
refurbishment projects & Tendering and planning \\
& Site inspection \\
\hline
\end{tabular}




\section{Discussion}

The studied refurbishment initiatives are heterogeneous innovation networks that are thematically as well as organisationally controlled by central management units. Although important decisions are made in coordination with most network partners, self-organised communication between the company partners is rare. Social capital as a principle for interaction is clearly underdeveloped and, therefore, not relevant so far. In the building industry, social capital is based mainly on positive joint-project experiences. Company representatives' 'get-togethers' in training seminars have a positive effect, but happen much too seldom to establish stable and trusting connections. There appears to be a correlation between the size of the network and the opportunity to set up social capital. With the increase in size, it is more difficult to establish trusting relations. Another problem with size is the membership structure. It is obvious that networks consisting partially of direct competitors are at a disadvantage regarding trust and cooperation.

As we can see in our examples, the networks have to cover a wide range of functions that are often very different from one another. This variety could also act as an indicator for the complexity of innovations in the field of sustainable refurbishment. This is not about the development of a new product and its successful market launch, but rather, the networks have to create several sets of services and products based on new knowledge, skills and technology, which can take specific shapes at the project level.

A feature of both networks is that the innovation focus has been fixed from the outset on sustainable refurbishment. Perhaps this precondition may explain the dominant role of the management units. It is likely that self-organised company networks are more open and market-oriented and it seems that the core competence of the management shows far-reaching effects on the nature of the networks. In both cases, the technical know-how on energy issues and sustainable refurbishment of the initiators was of major importance.

The transfer of knowledge and skills is clearly the main characteristic of both networks. In the Ecomodel, the homeowners are provided with comprehensive, up-to-date refurbishment information. The Old dream house network is very good at qualifying and training. However, the combination of internal qualification and networking demonstrates some problems as well. The size of the network is in structural conflict with the thematic alignment. The more different interests are to be considered, the wider and, therefore, more time-consuming and expensive the programme development is. It also appears to be very difficult to offer a relevant and interesting qualification programme over a longer period.

Setting up innovation networks does not necessarily lead to market-relevant innovations - of course, this is not only true for our cases. In terms of market success, the impact of the studied networks is still minor. Although the situation on the supply side has improved considerably, the possibilities of networks to influence demand is obviously limited. For example, the necessary resources to launch and sustain a new trademark and inform the public continually about the network activities are far beyond the network's means. In both examples, the management tries to close the gap between the market (customers) and hierarchy (politics); the impact especially on the regulatory framework (e.g., building code, subsidy scheme) - which is crucial for the market success of comprehensive retrofit concepts - is not strong enough. The underdeveloped 
market is the main reason for the small number of newly created cooperations on the project level. However, the cooperations of complementary trades on a very local level would be necessary to cope with comprehensive retrofit jobs in the future.

\section{Summary and conclusions}

In this paper, we have presented two case studies on innovation networks in the field of sustainable refurbishment. From an ecological perspective, the modernisation of private houses offers a large potential to reduce $\mathrm{CO}_{2}$ emissions through energy savings. Innovation networks should, therefore, close the existing gap between demand and supply by improving the technical offer, as well as by stimulating the demand.

From a theoretical view, innovation networks are seen as a strategy to cope with these challenges. In innovation networks, material and symbolic resources can be mobilised and combined. Through interaction within networks, the processes of changing, searching and learning can be stimulated, reducing uncertainties in the innovation process and helping improve the market position of the network partners. If specific conditions are fulfilled, social networks are considered powerful sources of innovation. However, empirical studies show that under real conditions, innovation networks are confronted with a number of internal and external problems.

Both of the presented innovation networks focus on sustainable refurbishment in the private sector and both have been active in two different Austrian regions, trying to promote and support innovations for sustainable refurbishment on the local level for several years. Although very close in geographical terms, both initiatives were developed independently of one another. In spite of this, we found many similarities. In both cases, the network activities are coordinated by central units. In addition to network management tasks, these units are also responsible for several other functions: public relations, training seminars, strategic development, advisory services for end users and the implementation of refurbishment measures. The necessity to cover such a wide range of different functions is an indication of the complexity of innovations in the field of sustainable refurbishment.

Both networks are driven by the idea of changing practices in the building industry towards sustainability. This goal was fixed from the outset and is closely linked to the initiator's core competence. It seems that these core competencies show strong effects on the development of the networks. Therefore, it is not surprising that the transfer of knowledge and skills is one of the strengths in both cases.

Learning about sustainable technology and practical skills together does not lead to the development of sufficient social capital. Moreover, it seems problematic if direct competitors participate in one and the same network. In order to establish trustful relations, the project-based experiences of mutual cooperations are of vital importance.

As our case studies show, setting up innovation networks does not necessarily lead to market relevant innovations. There are limitations on both sides. On the one hand, the influence on the performance and strategies of the members - concerning skills, knowledge and offered products - is limited. On the other hand, these networks are not able to open up the market for sustainable refurbishment. The resources for public relations are not sufficient. In order to increase the demand for sustainable refurbishment, changes are needed, above all, in the regulatory framework. 


\section{Acknowledgements}

We are grateful to the Ministry for Transport, Innovation and Technology (BMVIT) for funding our research and to the Austrian Society for Environment and Technology (OGUT) for managing the programme 'Building of Tomorrow'.

\section{References}

Coleman, J. (1988) 'Social capital in the creation of human capital', American Journal of Sociology, Vol. 94, Supplement, pp.95-120.

Energieinstitut Vorarlberg (Ed.) (2003) Neuer Energien für alte Häuser. Ein Leitfaden zur energieffizienten und ökologischen Wohnbausanierung, Dornbirn.

Fürst, D. (2001) 'Die Bedeutung von Netzwerken in modernen Gesellschaften', in H. Kanning (Ed.) (2001) Netzwerke und Nachhaltigkeit: Vernetzte Probleme - vernetztes Denken vernetzte Lösungen, Schriftenreihe des Doktoranden-Netzwerkes Nachhaltiges Wirtschaften e.V., Band 6, Hannover, pp.5-15.

Hellmer, F., Friese, Chr., Krollos, H. and Krumbein, H. (1999) Mythos Netzwerke - Regionale Innovationsprozesse zwischen Kontinuität und Wandel, Edition sigma, Berlin.

Küppers, G. (2002) 'Complexity, self-organisation and innovation networks: a new theoretical approach', in A. Pyka and G. Küppers (Eds.) Innovation Networks, Theory and Practice, Cheltenham: Edward Elgar, pp.22-52.

Küppers, G. and Pyka, A. (2002) 'The self-organisation of innovation networks: introductory remarks', in A. Pyka and G. Küppers (Eds.) Innovation Networks, Theory and Practice, Cheltenham: Edward Elgar, pp.3-21.

Majer, H. (2005) 'Institutionelle Innovationen für Nachhaltigkeit', http://www.nachhaltigkeit.at/ reportagen.php3?id=9\#K8 (accessed 5 February 2006).

Minsch, J. (n.d.) 'Gedanken zu einer politischen Kultur der Nachhaltigkeit', http://www.iff. ac.at/socec/backdoor/sose05-ring-sozoek/03_Minsch_04.pdf (accessed 15 April 2005).

Ornetzeder, M. and Suschek-Berger, J. (2005) 'Einfamilienhäuser innovativ sanieren: Erfolgskriterien und Übertragbarkeit von Best-Practice-Modellen im Einfamilienhausbereich', Berichte aus der Energie- und Umweltforschung, Ministry for Transport, Innovation and Technology, Vienna, Vol. 43.

Perry, N. (1993) 'Scientific communication, innovation networks and organization structures', Journal of Management Studies, Vol. 30, No. 6, pp.957-974.

Porter, M. (1980) Competitive Strategy, New York: Free Press.

Putnam, R. (1993) Making Democracy Work, Princeton: Princeton University Press.

Rohracher, H. and Ornetzeder, M. (2002) 'Contextualising green buildings: improving social learning processes between users and producers', Built Environment, Vol. 28, No. 1, pp.73-84.

Schuster, G., et al. (2000) 'Wärmeschutzmaßnahmen an Wohngebäuden: Grundlagen für CO2-Einsparpotentiale des österreichischen Nachkriegswohnbestandes', Zentrum für Bauen und Umwelt, Krems.

Weber, M. (2002) 'Innovation networks and the transformation of large socio-technical systems: the case of combined heat and power technology', in A. Pyka and G. Küppers (Eds.) Innovation Networks, Theory and Practice, Cheltenham: Edward Elgar, pp.133-168. 


\title{
Passive houses in Austria: the role of intermediary organisations for the successful transformation of a socio-technical system
}

\author{
Michael Ornetzeder \\ Institute of Technology Assessment of the \\ Austrian Academy of Sciences \\ Austria \\ ornetz@oeaw.ac.at \\ Harald Rohracher \\ IFZ - Inter-University Research Centre for \\ Technology, Work and Culture \\ Austria \\ rohracher@ifz.tugraz.at
}

\section{Keywords}

passive houses, sustainability, intermediaries, socio-technical systems, technological innovation system, bounded sociotechnical experiments, strategic niche management

\section{Abstract}

In Austria, the first passive house was built in 1996. Since then the market for passive houses has rapidly increased. Statistics show that there were more than 4000 residential units with about 10,000 passive house residents at the end of 2006 - more per capita than in any other country of the world. Sustainability requirements, however, have led to profound shifts in the need for collaboration between the actors involved in planning, constructing and using buildings.

This paper draws on a qualitative case study to analyse the development and dissemination of passive houses in Austria by focussing on the role of intermediate organisations. Empirically, the paper is based on qualitative interviews with representatives of relevant organisations as well as the analysis of various documentary sources.

The case study shows that new types of buildings, such as 'passive houses', have given rise to new actors and organisations to organise integrative planning processes, to set standards and market the passive house concept, to certify components, to transfer knowledge to professionals, to assist consumers in choosing architects, installers and technologies or to organise participation processes. New interest organisations mediate between producers and the policy level, energy agencies act as system builders to transfer these new technologies and practices into the mainstream building sectors, etc. Intermediation processes fulfilled by a broad range of organisations turned out

to be of crucial importance for the coordination and shaping of the socio-technical system.

\section{Introduction}

A significant proportion - up to $40 \%$ - of the energy consumption of industrialised societies is caused by the operation of buildings, i.e. heating, cooling, lighting, use of various electric appliances. This energy is used in an extremely inefficient way by the existing building stock, which leaves us with enormous and often cost-efficient potentials to reduce our overall energy use and as a consequence significantly reduce greenhouse gas emissions. Even without the use of sophisticated and advanced technologies an efficiency improvement by a factor of 10 compared to the total building stock and at least a factor 5 compared to current building codes and design practices for new buildings can be achieved without considerable rises in building costs.

While the innovation behaviour of the construction sector (especially residential buildings) has long been regarded as conservative and rather slow in the uptake of new technologies and processes (see e.g. Nam \& Tatum 1988, Pries \& Janszen 1995 , Toole 1998) the sector is increasingly coming under pressure. On the one hand new technologies are changing design practices (e.g. design and simulation software) and the organisation of the construction process (e.g. increasing prefabrication of components while at the same time maintaining a high flexibility to adapt products to customer and site demands), on the other hand the pressure on environmental and energy efficiency standards as well as the implementation of the EU directive on the energy performance of buildings increases and requires a re-organisation of current building practices. Higher 
environmental standards require a higher systemic integration of the building: efficient ventilation systems with heat recovery e.g. require an air-tight building envelope; 'intelligent' handling of solar radiation and heat loads within the building requires specific design features; characteristics of building services, design of building structure, properties of building envelope have to positively interact if energy efficiency potentials are to be harnessed. The focus of such types of innovation is not so much on new technologies but rather on so-called architectural innovations (Henderson \& Clark 1990), i.e. new combinations and interrelations of components. However, such integration cannot merely be achieved at the technical level, but requires socio-technical integration such as a closer collaboration of companies and professionals involved, new competencies, regulations, communication structures etc. What is needed thus is a process of profound socio-technical change in the building sector, change that encompasses technologies and social practices alike.

For environmental (energy/climate) policy the crucial question is, how it is possible to facilitate such sectoral transformation processes and direct them towards desirable outcomes, in our case towards construction practices resulting in energyefficiency, low material consumption and economic affordability of buildings. Obviously, the governance of sectoral transformation processes involves complex coordination tasks, a situation which is aggravated by the fact that the construction sector (just like other sectors) is not centrally and hierarchically organised but depends on the interests, power and strategies of a multiplicity of actors.

As we will point out in more detail below, socio-technical transformation processes usually start in limited market or technological niches or generally in emergent new socio-technical constellations, which eventually may radically transform existing practices at a broader scale. In the case of buildings, the evolving niche of highly energy efficient passive houses seems to have the potential to profoundly transform existing construction practices - at least in countries like Austria. However, in other countries similar concepts, such as carbonneutral buildings in the UK, exist. Passive houses in Austria are a well-suited example to study transformation processes in the building sector and factors, which contribute to a successful growth of this emergent socio-technical system.

In this paper we will analyse the development of passive houses in Austria over its first decades. In our analysis we will draw on different concepts from innovation studies and social studies of technology to be able to better assess the performance of this new socio-technical niche and identify potentials and challenges in the way this niche is organised as well as in its institutional contexts. The development and diffusion of passive houses by no means is merely a process of technological improvement and optimisation of construction processes, but profoundly is embedded in social and cultural contexts. Moreover, we will focus on a type of actors which is crucial to organise this change process, as new actors and organisations are needed e.g. to organise integrative planning processes, to set standards and market the passive house concept, to certify components, to transfer knowledge to professionals, to assist consumers in choosing architects, installers and technologies or to organise participation processes. New interest organisa- tions mediate between producers and the policy level, energy agencies act as system builders to transfer these new technologies and practices into the mainstream building sectors, etc. Such intermediation processes fulfilled by a broad range of organisations turn out to be of crucial importance for the coordination and shaping of the socio-technical system.

Before engaging in more depth with our case study analysis we want to set out some hypotheses and conceptual background regarding the development of new socio-technical niches, the role of intermediary organisations and generally the establishment of new socio-technical practices.

\section{Niches, innovation systems and intermediation processes as basic concepts to understand the socio-technical development of passive houses}

\section{SOCIO-TECHNICAL NICHES AND INNOVATION SYSTEMS}

Transforming the construction sector towards sustainability certainly is not a straightforward process of developing new technologies or designs. In order to establish new and sustainable construction practices a growing number of actors has to be aligned to this new concept, new institutions have to be established and institutional contexts modified etc. In the context of science and technology studies there are three related concepts which try to better conceptualise the establishment and growth of new socio-technical constellations such as passive houses: the concept of niches and their strategic management, the concept of bounded socio-technical experiments and the concept of technological innovation systems.

Especially the niche concept has to be seen in the context of a multi-level model of innovation. The multi-level perspective of socio-technical transitions distinguishes socio-technical transformation dynamics at different levels of aggregation: a microlevel of niches (technological projects, emerging technologies, e.g. early passive houses) as a source of variety and an 'engine for change', a meso-level of regimes understood as "semi-coherent set of rules" (Geels 2004, 904) (such as the construction regime) providing stable structures and a selection environment for innovations and a macro-level of socio-technical landscapes as slowly changing socio-technical contexts at the level of societies (Rip \& Kemp 1998). A strength of the multi-level perspective lies in explaining the resistance to radical innovations due to the stability of regimes as a rule set or grammar that structures and coordinates both actors and technologies within functional subsystems of society on the one hand and on the other hand in providing a concept for the success and dynamics of radical innovations as regime transitions following pressures on these regimes by evolving niches (Weber \& Hoogma 1998) or changes at the landscape level (Geels \& Schot 2007). In a 'normal' case, niches do not gain enough strength to transform regimes. However, there are certain patterns which can be observed, when niches contribute to radical change (Geels 2002, 1271-72): several niches can cumulate and gradually transform a regime, niches can link up with established technology as technological add-on or hybridisation, or niches can break out of their confinement by 'riding along' with the growth of a particular market. In our case study on passive houses we will 
focus on such processes through which niches can substantially impact on existing regimes.

Strategic niche management (see e.g. Hoogma et al. 2002) refers to the creation and nurturing of protected spaces (e.g. market niches, controlled field experiments) to broaden the design process by involving a broader range of actors and facilitate interactive learning of the actors participating. A central aim of the development of niches is to learn about needs, problems and possibilities connected with the environmental innovation experimented with, and to help articulate design specifications, user-requirements or side-effects of the innovation. Managing the development of environmental technologies in niches (and finding the right timing to open these niches to the wider market and competition) certainly is one of the more advanced and reflexive forms of managing environmental innovations and technologies by organising social learning process involving producers, technology designers and users in a joint process. This focus on conscious experimentation and learning is shared by the concept of bounded sociotechnical experiments (see Szejnwald Brown et al. 2003; Szejnwald Brown \& Vergragt 2008). Socio-technical experiments are "driven by a long-term and large-scale vision of advancing the society's sustainability agenda, though the vision needs not be equally shared by its participants. Its goal is to try out innovative approaches for solving larger societal problems of unsustainable technologies and services" (Szejnwald Brown \& Vergragt 2008, 112).

The internal structure of niches remains rather vague and the focus rather is on the interactions between niches and regimes. In contrast, the concept of technological innovation systems (TIS) (Carlsson \& Stankiewicz 1991) is putting more emphasis on the structure of TIS, i.e. the actor networks, institutions, knowledge base and its external blocking and inducement mechanisms (Johnson \& Jacobsson 2001). As it is related to a specific technology base, a TIS can consist of market niches, projects and experiments and can be local or global in scale (see e.g. Hekkert et al. 2006). Technological innovation systems are internally defined by technologies, actors, institutions and their relationships and dynamics. Research on TIS mainly concentrates on specific functions (or activities), which are important for the growth and performance of TIS, as well as on blocking and inducement mechanisms - often of an institutional type - as the influence of the TIS-environment. Typical functions of "emerging" innovation systems are (Bergek et al. 2008):

- Knowledge development and diffusion

- Influence on the direction of search (visions, expectations; regulation and policy; articulation of demand)

- Entrepreneurial experimentation (experiments in new applications and technologies)

- Market formation (development of niches and, learning spaces; user involvement; etc.)

- Legitimation (social acceptance and compliance with relevant institutions)

- Resource mobilisation

- Development of external economies, free utilities, variety, etc.
Our aim in the empirical part of the paper will be to analyse the growth of the socio-technical system of 'passive houses' before the backdrop of these concepts: as a series of small-scale sociotechnical experiments, as a managed niche challenging the existing construction regime, and as an emerging and growing technological innovation system gradually establishing actor networks and institutional relationships to fulfil the functions identified in the TIS-literature as a prerequisite of successful expansion.

\section{INTERMEDIATION AND COORDINATION}

Now let us turn to our second focus of analysis. The management of niches, the set-up of socio-technical experiments and facilitation of social learning processes, the provision of innovation-system-functions such as search orientation, legitimation, resource mobilisation etc. all require organised efforts of coordination, facilitation or governance. Such type of change processes are usually characterised by an absence of a central steering power (though there are certainly often significant differences in power between actors involved), by long-term orientation and a context of uncertainty.

They thus require actors, which mediate between the different groups involved: between users and producers, producers and policy, research and production or within the group of technology and product developers and suppliers constituting the niche or innovation system. As Moss $(2005,24)$ summarizes, intermediary functions include activities such as adapting technologies to contexts of application, translating knowledge into new products and services, connecting people, building networks, lobbying and advocating reform, or raising awareness and broadening perceptions. These functions are provided within four basic organisational forms: bridge builders (facilitating dialogues etc.), 'info-mediaries' (disseminating information etc.), advocates, and entrepreneurs (innovators and 'ecopreneurs').

The management and transition of socio-technical systems towards sustainability can be improved by a systematic support of mediation processes and different types of intermediary actors. A better understanding of new types of intermediation in socio-technical change, of the roles intermediary actors play in these processes and of the supportive conditions for intermediation, will help us to develop more appropriate strategies to support socio-technical transitions towards sustainability. The socio-technical niche of passive houses is an example of such a socio-technical change process towards sustainability, which has the potential to ultimately transform the whole sector of house building.

In the following sections we will analyse the development of passive houses before the background sketched out above: passive houses as an emerging socio-technical niche or innovation system and the role intermediary actors play in facilitating the growth of this niche. With this type of analysis we hope to better understand the socio-technical processes involved in the development of passive houses and to identify requirements and opportunities to turn this niche into a mainstream practice of constructing buildings. 
Table 1. Passive house standard requirements (Source: Passivhausinstitut 2009)

\begin{tabular}{|l|l|}
\hline Area & Requirements \\
\hline Space heating requirement & The building must not use more than $15 \mathrm{kWh} / \mathrm{m}^{2}$ per year in heating energy \\
\hline Air tightness & $\begin{array}{l}\text { With the building de-pressurised to } 50 \mathrm{~Pa}\left(\mathrm{~N} / \mathrm{m}^{2}\right) \text { below atmospheric pressure by a } \\
\text { blower door, the building must not leak more air than } 0.6 \text { times the house volume per } \\
\text { hour }\end{array}$ \\
\hline Total primary energy consumption & $\begin{array}{l}\text { Total primary energy consumption (primary energy for heating, hot water and electricity) } \\
\text { must not be more than } 120 \mathrm{kWh} / \mathrm{m}^{2} \text { per year }\end{array}$ \\
\hline Specific heat load & $\begin{array}{l}\text { The specific heat load for the heating source at design temperature is recommended (not } \\
\text { required) to be less than } 10 \mathrm{~W} / \mathrm{m}^{2}\end{array}$ \\
\hline
\end{tabular}

\section{Case study on Passive Houses}

\section{PASSIVE HOUSE AS ENERGY STANDARD FOR BUILDINGS}

A "passive house" is a building that meets a specific energy standard (see Table 1). The original concept for this standard was developed by Bo Adamson from the University of Lund (Sweden) and German physicist Wolfgang Feist from the Institut für Wohnen und Umwelt (Institute for Housing and Environment) in the year 1988. In the 1990s the concept was developed through a number of German research projects. The first building according to the passive house standard was built in Darmstadt in 1990 (Passive House Kranichstein). This building, a four-unit row house, was both regularly used by homeowners as well as a research and demonstration project (Feist 2006).

Passive houses need about $80 \%$ less heating energy than new buildings designed to the standards of the 1995 German Thermal Insulation Ordinance. The standard has been named "passive house" because the passive heat inputs - delivered externally by solar irradiation through the windows and provided internally by the heat emissions of appliances and occupants - essentially suffice to keep the building at comfortable indoor temperatures throughout the heating period. But it is also a part of the passive house philosophy that efficient technologies are used to minimize the other sources of energy consumption in the building, notably electricity for household appliances. The overall energy demand in a passive house is lower by at least a factor of 4 than the specific consumption levels of new buildings designed to the standards presently applicable across Europe (Passivhausinstitut 2009). As the standard focuses on energy consumption only, several initiatives to discuss and extend the passive house standard in the wider context of sustainability - covering aspects like ecologically rated constructions, resource consumption, indoor environmental quality or quality of service - have been launched over the past years (Schuster and Lipp 2001; Waltjen, Pokorny et al. 2008).

The "passive house" standard can be met using a variety of technologies, designs and materials. However, designing a passive house means to consider the following construction principles (Passivhausinstitut 2009):

- Maximizing passive solar gain: using windows with lowemissive triple glazing and super-insulated frames, main glazing areas are oriented to the south and are not shaded;

- Using super-insulation: exceptionally good thermal envelope, preventing thermal bridging and air leakage;

- Combining efficient heat recovery with supplementary supply air heating (ventilation system);
- Using high-efficiency appliances only;

- Meeting the remaining energy demand with renewable energy sources.

Built passive houses show a variety of architectural stiles. While most of the realised projects feature characteristically ecobuilding attributes, like large southwards-oriented windows and reduced stylistic elements, in recent years also Passive houses that are hardly to distinguish from normal buildings have been built.

\section{DISSEMINATION OF PASSIVE HOUSES IN AUSTRIA}

Although in the beginning most of the passive house activities took place in Germany, the concept soon was adopted in Austria too. The first passive house was built in the province of Vorarlberg in 1996 by a private owner. In the year before, a first refurbishment-project aiming at passive house standard was completed in the same province (Lang 2004). More buildings in other provinces followed shortly after. Figure 1 shows the diffusion of passive houses in Austria since 1995. While in the second part of the 1990s the total number of buildings rose continuously on a low level it has significantly increased in the last years. Since 2004 the yearly growth ratios add up to more than $40 \%$. At the end of 2007 there are more than 4000 residential units completed with about 10,000 passive house residents throughout Austria. Most of these buildings are newly constructed private single-family houses. Although the passive house standard has mainly been adopted in this sector, other types of buildings such as several larger residential buildings, office buildings, schools and kindergartens, and even a supermarket have been constructed according to the standard.

In comparison to the existing building stock and the absolute number of new buildings finished per year these figures are still small. Statistics show that around $4 \%$ of all new residential buildings in Austria have been constructed according to the passive house standard in 2006. However, according to estimates the share of passive houses could reach $30 \%$ or even more within the next few years. In some regions the share of passive houses is already clearly over the national average. The leading province in this respect is Vorarlberg with almost 14\% share of passive houses of all new buildings in 2007 (IG Passivhaus 2009). Experts think that it is most likely that the passive house standard will leave its market niche and will become one of the leading energy standards at least for newly constructed buildings. The fact that the standard is specified in the subsidy schemes for residential buildings in six out of nine Austrian provinces serves as a strong argument for this prediction. In these provinces new buildings that meet the passive house 


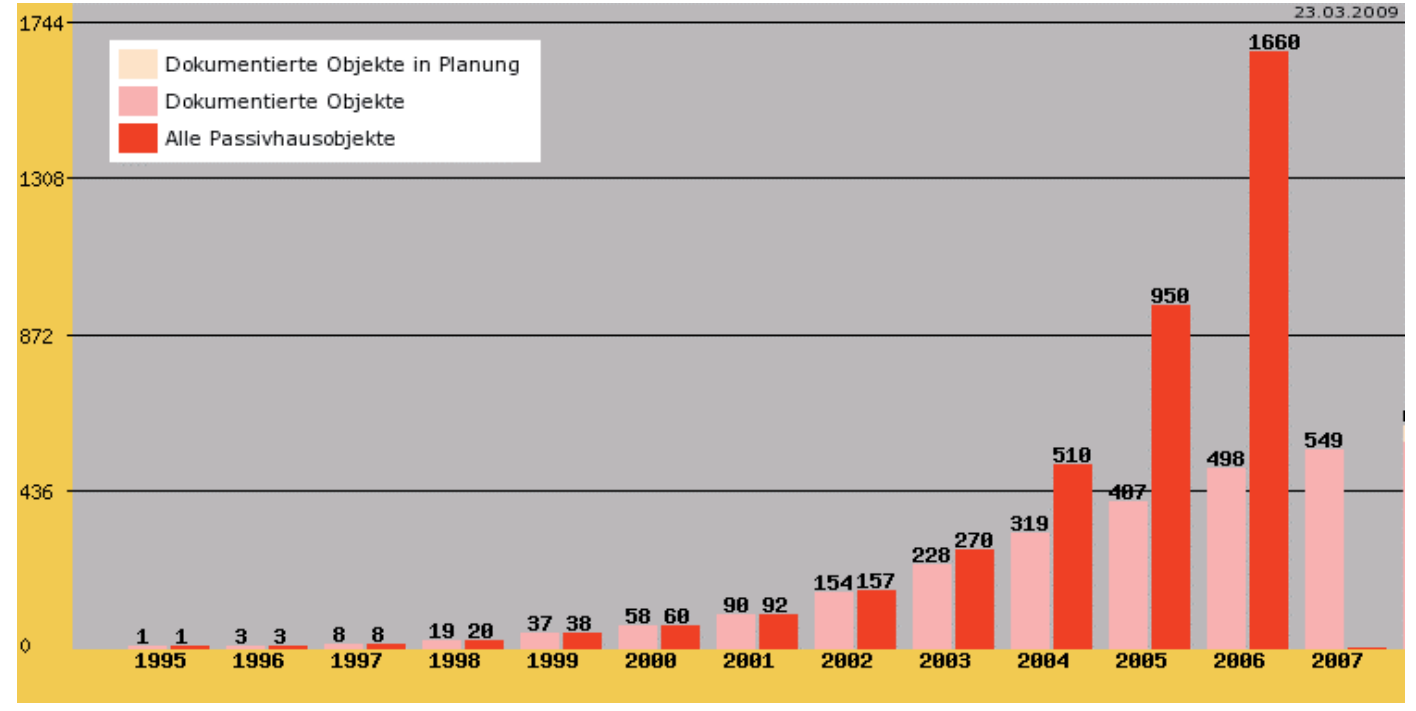

Figure 1. Dissemination of Passive Houses in Austria. (Dark red bars are number of completed passive houses) (Source: IG Passivhaus)

criteria already may expect to get up to $30 \%$ higher subsidies compared to low-energy houses. Moreover since 2007 in one of the provinces (again Vorarlberg) the passive house standard is obligatory for social housing projects. In the meantime the term "Passivhaus" is widely known by the informed public and in most cases perceived positively.

At the moment Austria is the worldwide leading country regarding the diffusion of passive houses. Compared to Germany, which is leading in absolute numbers, there are 2,5 times more passive houses per capita in Austria (IG Passivhaus 2009).

\section{A BRIEF HISTORY OF THE PASSIVE HOUSE IN AUSTRIA}

In this section we will describe the development of the passive house activities as a sequence of typical phases. Each of these phases is characterised by typical socio-technical arrangements - actors entering the market or coordinating activities, regulations and institutions being changed and set-up etc. - and each poses specific challenges for the further development and diffusion process. Based on interviews with passive house practitioners and available written documents the development of the passive house four such phases - each with typical activities - could be identified. The development of the passive house concept originally started as a scientific challenge. This early set-up phase was followed by a regional niche growth in the Austrian province of Vorarlberg. Based on instructive regional experiences the niche could grow to the national level. In recent years the socio-technical niche of the passive house increasingly becomes institutionalised and stable.

\section{Early set-up phase (1988 - 1996)}

In this first phase the main focus of all passive house activities was to establish an advanced energy standard by defining a set of criteria to be met and to demonstrate that the concept could work in practice. In the 1980s the passive house standard was only one idea to change the energy needs in buildings among others. The basic vision was to minimise the energy losses as far as possible. Most other concepts did focus on maximising active solar gains. Pilot projects of that time - like the "JenniHaus", Switzerland, or the Energy Self-sufficient Solar House in Freiburg, Germany - give evidence that it was a time of sociotechnical variation with different competitive concepts.

In these first years Wolfgang Feist together with some colleagues from the Institute for Housing and Environment developed the socio-technical core (Weyer 1997) of the passive house concept. This socio-technical core consisted of the basic vision (minimize energy losses), threshold values and requirements for the Passive House energy standard and preliminary technological specifications and construction principles.

Early experiments with the first demonstration building in Darmstadt (Passive House Kranichstein) showed that the concept would work - at least under specific conditions (use of best available or yet to be developed technology, perfect integration of used technologies, consideration of some architectural rules). Based on extensive data collection at the demonstration building in Kranichstein and simulation models a softwaretool for the design of Passive Houses was developed (Passive House Planning Package, PHPP). The development of the passive house concept and early experimentation took place in the context of the German 'Institut für Wohnen und Umwelt (IWU)' (institute for housing and environment), a publicly owned, interdisciplinary research institute which is also devoted to turn research results into practice in cooperation with various non-research partners. Like similar institutes the IWU took over the role of a research intermediary, coordinating the transfer of research ideas into practice, establishing pioneering actor constituencies, promoting certain concepts in public and at the policy level etc.

At the end and as a result of the set-up phase the Passivhausinstitut was established in Darmstadt (Germany) in 1996 as an independent research institution and as an intermediary specifically devoted to organising the further development and diffusion of passive houses. The institute offered consulting for architects and engineers, a certification scheme for passive houses and started to organize an annual interna- 
tional conference on passive houses. Although many technical and other problems were unsolved at that time the available research findings and practical experiences helped to stabilize the socio-technical core of the concept. Around this proved socio-technical core the institute could be established and dissemination activities could be started.

\section{Regional niche growth (1993 - 1999)}

While the passive house concept was just in development it was already adopted in Austria. This regional dissemination of the passive house was characterised by early projects almost exclusively situated in the province of Vorarlberg. And what is more important, those early-realised buildings had not been built for demonstration purposes but to meet regular habitation needs. Within only a few years a reasonable number of passive houses were constructed and regularly used ${ }^{1}$. This was possible by and resulted in a local passive house community, consisting of architects, energy consultancies, planners, producers of passive house technology (e.g. ventilation systems) and building companies.

In this phase the Energy Institute Vorarlberg (EIV) ${ }^{2}$ served as the central change agent. The institute was responsible for the initial knowledge transfer from Germany, the dissemination of the concept in the region and it served as a platform for communication, cooperation and learning. Every new passive house project was documented and discussed at an annual summer school and similar meetings. Positive as well as negative experiences were not only disseminated within the local community but from the beginning this knowledge has also been connected to the developments in Germany. As a consequence, research on passive houses very early could build on a broader range of practical experiences and the other way round practitioners could profit from newest research findings. The EIV soon became a 'crystallisation point' for the emerging 'community of practice'.

As the EIV served also as a think tank for the regional government it was able to influence regional building policies. In

1. The local builder Richard Caldonazzi designed and constructed the first passive house in 1996. It became the first residential house without conventional heating system in Austria. The building was extremely well insulated ( $35 \mathrm{~cm}$ cork), equipped with special triple-pane glazing, a custom-built ventilation system and a solar water heater. As it turned out that the building concept worked very well in practice, the later called "Caldohaus" soon became an attraction for ecologically interested architects, energy experts, commercial builders as well as prospective building-owners. Till this day more than 3000 people had the opportunity to visit the Caldohaus in organised field trips - most of them organised by the EIV. In 1997 a five-unit row house project was completed. It was equipped with specially designed windows and a new type of ventilation unit combining a heat exchanger and a heat pump. This concept - although deficient in this first version - became the prototype for the so-called "compact device", the now best-selling ventilation system for passive houses in Austria. The first apartment house project aiming at passive house standard was constructed only shortly after. Just as the two smaller buildings before, this project offered extremely important learning opportunities too. In this project most tenants were extremely dissatisfied in the beginning. An evaluation project most tenants were extremely dissatisfied in the beginning. An evaluation
showed among other things serious technical problems with the ventilation system. showed among other things serious technical problems with the ventilation system. It also became clear that the quality of the windows would be extremely important in Passive Houses and that the main glazing areas have to be oriented entirely to the south to receive enough passive solar gains. This project showed that the average tenant would be much more critical and sensitive to problems than a highly
motivated homeowner.

2. The Energieinstitut Vorarlberg (EIV) is an independent non-profit organisation based in the province of Vorarlberg. Founded in 1985 by the local government and major regional stakeholders, the EIV concentrates on the rational use of energy, renewable energies and ecological buildings. The institute offers training and consulting for private households, companies and communities, but it is also involved in some research activities and serves as an influential think tank for the local government.
Vorarlberg, building legislation and subsidies strongly supported low-energy houses and therefore the construction of passive houses.

The dynamic growth within this geographically small regional niche soon attracted attention. Architects from other Austrian provinces became familiar with the passive house concept and realised first buildings. This resulted in several private passive house projects in other provinces, which provided an important basis for the following phase.

\section{Outgrowing the niche at national level (1998-2005)}

Surprisingly the broadening of the passive house niche to the national level was mainly driven by research activities. Firstly, the EU-project CEPHEUS ${ }^{3}$ stimulated the set-up of additional demonstration projects in several provinces. Secondly, one year later the national research programme 'Building of Tomorrow ${ }^{4}$ was launched. Both initiatives helped to improve and spread knowledge on passive houses on a national level and supported the dissemination of realised buildings significantly. Moreover the increased research dynamic stimulated new cooperation and the establishment of a national passive house research community. Important national actors from the building sector (solar energy architects, research institutes, companies, technology providers, etc.) and new intermediaries (consultancies such as Environmental Advice Centres) became involved in emerging research networks.

The national programme 'Building of Tomorrow' could also be seen as a national effort to integrate and homogenise different concepts of sustainable buildings. Contrary to the CEPHEUS project the longer and much larger research programme 'Building of Tomorrow' enabled and forced the integration of divers concepts like active solar, green buildings or passive houses. Through research the passive house energy standard also became a topic in the field of refurbishment and modernisation of the existing building stock.

At the end of this phase the knowledge about passive houses as well as the available technology has changed considerably. Today it is no problem to choose between several national sup-

3. CEPHEUS was the first trans-national research project on passives houses funded by the European Union. CEPHEUS - which is short for "Cost Efficient Passive Houses as European Standards" sive Houses as European Stancards - was to learn more about ultra-low energy houses under diferent climatic conditions and to improve and promote the passive Swiss, Swiss, French and German partner organisations. Austria was able to contribute the largest number of projects ( 9 out of 14) as well as residential units (84). The Austrian examples covered a broad range of possible passive house designs, construction materials and building forms: Freestanding single-family houses, terraced houses and multi-floor apartment buildings built with solid, light or mixed building techniques (Krapmeier and Drössler 2001)

4. In 1999 the Austrian Federal Ministry of Science launched the first missionoriented research programme on Technologies for Sustainable Development. The thematically focus of the first sub-programme was on sustainable buildings (called "Building of Tomorrow"). The aim of this programme was to develop and to promote the market introduction of components, construction elements and to promote the market introduction of components, construction elements and
methods for residential and office buildings which conform to the guidelines for methods for residential and office buildings which conform to the guidelines for sustainable development. In the concept of the programme it was also stated that 列 developments: the (active) solar building concept and the passive house concept 5. During the last years a number of research projects have been carried out within the framework of the research programme 'Building of Tomorrow'. Among studies dealing with more general technical questions a number of reports document different types of refurbishments aiming at passive house standard: Singlefamily house (Lang et al. 2007), multi-floor building (Domenig-Meisinger et al. 2007), school building (Obermayr 2004). According to IG Passivhaus 30 passive house refurbishment projects had been completed in Austria by the end of 2006 (IG Passivhaus 2009) 
pliers of special passive house windows and other passive house specific technology. All over the country it is easy to find architects with passive house experience. The term passive house is widely known as a quality label for ultra-low energy buildings. Again, this was to a great extent caused by the 'Building of Tomorrow' programme, which not only funded a huge number of research projects but also made much effort to disseminate information and popularise the topic of sustainable buildings.

\section{Institutionalisation and stabilisation (since 2001)}

The so far last phase is characterised by growing importance of interest organisations, a broad acceptance of the passive house concept in the general public and the increasing influence of the passive house standard on subsidy guidelines and legislative norms. In the last years we could also observe that the passive house concept has been linked up with important policy aims, especially with climate mitigation policy.

The establishment of the IG Passivhaus is very important in this respect. The IG Passivhaus is an interest group focussing on the dissemination of the passive house concept. It was founded in 2001 - not surprisingly - in the province of Vorarlberg. Drexel \& Weiss, the leading Austrian producer of ventilation systems, was mainly responsible for this organisational step. This company was involved in most of the early passive house projects and designed - based on these experiences - the first compact ventilation system for passive houses. Later, the marketing manager of this company realised that the success of this new compact system would be closely linked to the market success of the passive house in general. Hence he consulted all the other companies in Vorarlberg, which had already experiences with the construction of passive houses. As a result the IG Passivhaus Vorarlberg was founded. The eleven founding organisations represented a wide spectrum of competences and areas. As the mission of the IG was strictly oriented at the dissemination of the passive house concept the Energy Institut Vorarlberg decided to become a founding member too. In the following years Drexel \& Weiss tried to build up both a market for ventilation systems as well local interest groups in other Austrian provinces; and both worked out quite well. Since2006 the IG Passivhaus operates on the national level with regional branches in most of the provinces. Although financed by private companies the IG Passivhaus aims at company and product neutral passive house lobbying. Major aims are public relations activities, political lobbying (e.g. for higher subsidies) and the dissemination of information for the general public.

\section{Discussion}

With a focus on intermediation activities we can learn a number of lessons from the passive house case study.

One conclusion, which we can certainly draw from our analysis, is that the socio-technical system of passive houses has not been a development centrally planned, coordinated and steered by public policy or any other single actor. Passive houses have been very much developed in a bottom-up fashion without central steering but requiring a high degree of coordination and intermediation processes. Various processes had to be facilitated and coordinated:

- the development of technical and design standards;
- the creation of a vision and orientation for the further development of the passive house niche (general standard of the future; costs only slightly exceeding the costs of conventional houses; increasing focus on solar energy use and renewable building materials, etc.);

- certification procedures for building components meeting the passive house standard to make it easier for users and supply side actors (such as builders, architects, construction companies, component producers, etc.) to find appropriate components on the market;

- the dissemination of information about passive houses;

- the creation and extension of a competent actor constituency (training courses, PR for passive house architecture, etc.);

- support for the development of qualified demand structures (i.e. home owners or building developers who know what to ask for, whom to ask and how to assess the quality of offers when they intend to build an energy efficient building), etc.

These processes were facilitated by a number of organisations of different type: public and private research organisations engaged in energy-efficient building design; private non-profit (e.g. the passive house institute) or commercial (e.g. consultancies) organisations, regional or national energy agencies offering energy advice, information dissemination and supporting the growth of actor constituencies; semi-public institutions such as management organisations for research programmes (such as 'building of tomorrow') or interest organisations (IG Passivhaus) coordinating the already stabilised passive house community and lobbying for better regulations and support structures. In sum, intermediation activities have been a crucial ingredient for the growth of the passive house niche and have been distributed over a large number of organisations. Some of these organisations have been especially set up as passive house intermediaries (Passivhaus-Institut, IG Passivhaus), but the larger part was made up from already existing organisations with a wide range of tasks, which were often only temporarily engaged in facilitating the development of passive houses.

Our case study also sheds light on the changing role of intermediation processes over time. Intermediation requirements undergo significant changes along the career path of a new socio-technical system. While the formulation of a coherent concept and vision was a central prerequisite in the early development phase to get researchers and interested pioneering companies and users interested in this concept, in subsequent phases the establishment of demonstration projects and the availability of technical components had to be coordinated; the growth of the actor constituency had to be facilitated (information, training, PR etc.). In more mature stages the extension of the niche to a national level, the accumulation of niches (integration of passive houses, solar architecture and ecological product initiatives into one broader and coherent concept), and finally institution building and institutional alignments became of predominant interest (support schemes, building codes, policy targets, etc.). If such a process is coordinated by one or a few organisations, a high degree of organisational flexibility is required to adapt to the changing intermediation tasks. In 
our case study the picture was somewhat different, as subsequent phases usually were characterised by different predominant intermediary organisations - the Passivhausinstitut in the set-up phase, the Energy Institute Vorarlberg in the creation of a regional niche, the programme management of 'Building of Tomorrow' in the establishing of a national niche and integration with other niches, and possibly the IG Passivhaus or similar organisations in creating supportive institutional contexts for the mainstreaming of passive houses. Summing up, the evolution and growth of the socio-technical system around the passive house concept is characterised by a succession of changing intermediation needs, which could be met by a succession of different intermediary organisations with a changing focus of activity.

Intermediation activities turned out to be closely related to the so-called 'functions of technological innovation systems' that we have discussed in the theoretical chapter at the beginning. A successful development performance of technical innovation systems such as passive houses is expressed by the fulfilment of a number of functions. Among these are

- 'orientation', i.e. vision building in the early development phase, the creation of an integrated vision (passive principles \& active solar technology \& ecological materials) in the more mature phase as well as an appropriate structure and orientation for further research activities;

- 'knowledge generation', i.e. research, the evaluation and dissemination of experiences, training courses etc.;

- 'entrepreneurial experimentation', i.e. experimentation with different design concepts and technologies;

- 'market creation', i.e. the articulation of qualified demand, the creation of a sufficiently large community of architects, planners, builders etc.; and finally the

- 'creation of positive externalities', i.e. knowledge spill-overs to conventional building practices which was overtly visible during the development of the passive house concept.

Intermediation processes thus are intrinsically linked up with the challenges faced by growing socio-technical systems (or technological innovation systems to use a related term) and thus also the strategic management of niches. Supporting the growth of niches and subsequently transforming socio-technical regimes such as the construction regime towards more sustainability needs intermediation activities of various types (systemic coordination, facilitation, brokering, advocacy, demand articulation, information transfer, etc.).

The strategic management of niches and the governance of system transformation towards sustainability are moreover characterised by a complex and often symbiotic relationship between commercial, civil society and public sector organisations. While it is true that the mode of governing socio-technical change has changed and in certain respects has moved farther away from the nation state and public policy, the state level and policy support are still of crucial importance for the success of change processes towards sustainability. Especially in the early phase of developing the core ideas and setting up early experiments, recruiting pioneers, etc. public policy only played a minor role - though most of the research involved was publicly subsidised. The more complex relation to the policy level is subsequently expressed by the fact that many of the intermediary organisations involved were formally independent organisations but often established, funded or even owned by various public administrative units. This is certainly the case for the various energy agencies involved in system building and the dissemination of passive houses (the Energy Institute in Vorarlberg is a quasi-public organisation) and this is also true for the management of the 'Building of tomorrow' programme where a private organisation managed a public programme in close cooperation with the responsible ministry. Intermediary organisations thus can be seen as an important vehicle for public policy to support change processes towards sustainability within new governance contexts. Our case study shows that such 'public governance through intermediaries' already takes place, but that there is still an enormous potential to improve information flow and cooperation between policymaking and intermediaries. A closer cooperation and use of intermediaries by public policy could improve the interrelations of supportive legislative, regulative and financial support structures on the one hand, and constituency building and market formation in a bottom-up perspective on the other. More research should be done to improve our understanding of integrated governance strategies comprising the public sector and civil society initiatives alike.

\section{Conclusions}

In our case study we have focused on the development of passive houses in Austria as an example of an emerging sociotechnical practice for the design of highly energy-efficient buildings, which has the potential and currently seems to set out to profoundly transform dominant construction practices of buildings. The example is of high public interest because it could serve as a model for other sectoral transformation processes towards sustainability.

A main focus of our analysis was on the role of intermediary organisations in their role as facilitators and coordinator of system building and change processes, as information brokers and generally as links and mediators between different societal subsystems such as economy, policy, research or civil society. Our investigation of the development of passive houses could provide interesting insights in the roles and challenges for intermediary organisations involved in socio-technical change. Though it is difficult to generalise from case studies, the development of passive houses is certainly not an untypical example for the development of new socio-technical niches. Intermediation processes fulfilled by a broad range of organisations indeed turned out to be of crucial importance for the coordination and shaping of system growth. An interesting insight was the changing type of intermediation requirements along the different development stages of the passive house niche and the succession of different organisations carrying out these intermediation activities at different stages. The relation between the governance of socio-technical change and public policy certainly was more complex than guessed at the start of the project. While there was indeed little hierarchic and direct steering of system change by the state, public policy and administration still did play a crucial role for the success of passive houses. On the one hand, many of the most important intermediary organisa- 
tions were publicly funded and were closely related with public organisations, on the other hand the interplay between public policy (and its responsibility for legislative and regulatory processes and financial support) and intermediary organisations as links to the heterogeneous constituency of actors and users needed for the growth of the passive house niche was of crucial importance. However, this complex relationship underlines the importance of a working constellation of intermediary organisations for public policy. There still is significant potential to improve the interaction between intermediaries and public policy and to more consciously involve intermediaries in system change towards sustainability as a strategy of public policy.

\section{References}

Bergek, A., S. Jacobsson, B. Carlsson, S. Lindmark, and A. Rickne (2008), 'Analyzing the functional dynamics of technological innovation systems: A scheme of analysis', Research Policy 37: 407-429.

Carlsson, B. and R. Stankiewicz (1991), 'On the nature, function and composition of technological systems', Journal of Evolutionary Economics 1: 93-118.

Domenig-Meisinger, I., A. Willensdorfer, et al. (2007). Erstes Mehrfamilien-Passivhaus im Altbau: Passivhausstandard und -komfort in der Altbausanierung am Beispiel eines großvolumigen MFH in Linz. Berichte aus der Energieund Umweltforschung. Bundesministerium für Verkehr, Innovation und Technologie. Wien.

Feist, W. (2006). "15th Anniversary of the Darmstadt Kranichstein Passive House." Retrieved 23.02., 2009, from http://www.passivhaustagung.de/Kran/First_Passive_House_Kranichstein_en.html.

Gann, D.M. (2000), Building Innovation. Complex Constructs in a Changing World, London: Thomas Telford.

Geels, F.W. (2002), 'Technological transitions as evolutionary reconfiguration processes: a multi-level perspective and a case-study', Research Policy 31: 1257-1274.

Geels, F.W. (2004), 'From sectoral systems of innovation to socio-technical systems. Insights about dynamics and change from sociology and institutional theory', Research Policy 33: 897-920.

Geels, F.W. and J. Schot ( 2007), 'Typology of sociotechnical transition pathways', Research Policy 36: 399-417.

Hekkert, M.P., R. Harmsen, and A. de Jong (2006), 'Explaining the rapid diffusion of dutch cogeneration by innovation system functioning, in Proceedings of the Conference: The biennial conference of the European Association for the Study of Science and Technology, Lausanne: Urecht University.

Henderson, R.M. and K.B. Clark (1990), 'Architectural innovation: the reconfiguration of existing product technologies and the failure of established firms', Administrative Science Quarterly 35: 9-30

Hoogma, R., R. Kemp, J. Schot, and B. Truffer (2002), Experimenting for Sustainable Transport. The Approach of Strategic Niche Management, London: Spon Press.

Johnson, A. and S. Jacobsson (2001), 'Inducement and blocking mechanisms in the development of a new industry: the case of renewable energy technology in Sweden', in
R. Coombs, K. Green, A. Richards, and V. Walsh (Eds.), Technology and the Market. Demand, Users and Innovation, Cheltenham/Northampton: Edward Elgar Publishing Inc., 89-111.

Krapmeier, H. and E. Drössler (2001). CEPHEUS Wohnkomfort ohne Heizung. Wien, Springer.

Lang, G. (2004). 1000 Passivhäuser in Österreich : Passivhaus Objektdatenbank Berichte aus der Energie- und Umweltforschung. Bundesministerium für Verkehr, Innovation und Technologie. Wien.

Lang, G., M. Lang, et al. (2007). Erstes Einfamilien-Passivhaus im Altbau: Umsetzung des Passivhausstandards und -komforts in der Altbausanierung von Einfamilienhäusern am Beispiel EFH Pettenbach. Berichte aus der Energie- und Umweltforschung. Bundesministerium für Verkehr, Innovation und Technologie. Wien.

Malerba, F. (2002), 'Sectoral systems of innovation and production', Research Policy 31: 247-264.

Moss, T. (2005), New Intermediary Services and the Transformation of Urban Water Supply and Wastewater Disposal Systems in Europe. Final Report to the European Commission.Section 6: Detailed Report. Accessed at http:// www.irs-net.de/intermediaries/ on 18-06-2006, Erkner: Institute for Regional Development and Structural Planning (IRS).

Nam, C.H. and C.B. Tatum (1988), 'Major characteristics of constructed products and resulting limitations of construction technology', Construction Management and Economics 6: 133-148.

Obermayr, H.-C. (2004). Erste Passivhaus-Schulsanierung. Berichte aus der Energie- und Umweltforschung. Bundesministerium für Verkehr, Innovation und Technologie. Wien.

Passivhausinstitut. (2009). „What is a Passive House?" Retrieved 23.02., 2009, from http://www.passiv.de/.

Pries, F. and F. Janszen (1995), 'Innovation in the construction industry: the dominant role of the environment', Construction Management and Economics 13: 43-51.

Rip, A. and R. Kemp (1998), 'Technological change', in S. Rayner and E.L. Malone (Eds.), Human Choice and Climate Change: Resources and Technology, Vol. 2, Columbus, Ohio: Batelle Press, 327-399.

Schuster, G. and B. Lipp (2001). Das ökologische Passivhaus. Berichte aus der Energie- und Umweltforschung. Bundesministerium für Verkehr, Innovation und Technologie. Wien.

Szejnwald Brown, H., P. Vergragt, K. Green, and L. Berchicci (2003), 'Learning for sustainability transition through bounded socio-technical experiments in personal mobility', Technology Analysis \& Strategic Management 15 (3): 291-315.

Szejnwald Brown, H. and P.J. Vergragt (2008), 'Bounded socio-technical experiments as agents of systemic change: The case of a zero-energy residential building, Technological Forecasting \& Social Change 75: 107-130.

Toole, M.T. (1998), 'Uncertainty and home builders' adoption of technological innovations', Journal of Construction Engineering and Management: 323-332. 
Waltjen, T., W. Pokorny, et al. (2008). Passivhaus-Bauteilkatalog : ökologisch bewertete Konstruktion. Wien; New York, Springer.

Weber, K.M. and R. Hoogma (1998), 'Beyond national and technological styles of innovation diffusion: a dynamic perspective on cases from the energy and transport sec tors', Technology Analysis \& Strategic Management 10 (4): 545-566.

Weyer, J. (1997), 'Konturen einer netzwerktheoretischen Techniksoziologie', in J. Weyer, U. Kirchner, L. Riedl, and J.F.K. Schmidt (Eds.), Technik, die Gesellschaft schafft, Berlin: edition sigma, 23-52. 


\title{
Participatory assessment of sustainable end-user technology in Austria
}

\author{
M. Ornetzeder, U. Bechtold, M. Nentwich \\ Institute of Technology Assessment of the Austrian Academy of Sciences, \\ Austria
}

\begin{abstract}
This paper reports on experiences using a participative technology assessment (pTA) approach to discuss and evaluate research and development goals for sustainable energy technology in Austria. In a two-day Future Search \& Assessment conference in November 2007, 36 per representative quota selected laypeople discussed the future of energy research in Austria on two different levels: general visions of sustainability as well as deduced short-term aspects regarding the present end-user related energy research agenda. The strategy chosen consists of a well-balanced mix of focus groups, plenary sessions, expert inputs, and moderated working groups. The five topics discussed in the laypeople's conference were: micro combined heat and power (micro-CHP), new system solutions and avoidance strategies, smart metering and 'intelligent' end user equipment, innovative contracting and leasing models, and visualization and monitoring devices. We aim to show that pTA can contribute twofold to technical innovation: Firstly, it can contribute to the social robustness of the underlying strategies and scenarios of relevant research programmes; and secondly, the research topics that directly refer to the end-users can be critically evaluated in terms of social acceptability and user friendliness. Moreover the chosen approach serves as a platform to discuss long-term energy policies as well as practical consequences.
\end{abstract}

Keywords: Energy technology, applied research, sustainability, end user, technology assessment, laypeople participation 


\section{Introduction}

The current energy system is mainly based upon fossil energy sources. To minimize or avoid severe negative consequences in terms of costs and effects for humankind and the biosphere this system has to face radical changes. The widely accepted goal is an efficient and secure energy supply system mainly based on renewable resources. Research and development activities will undoubtedly have to play a crucial role in this substantial transition, predominantly regarded as the only future option. However, end-users of new technological options will be of decisive importance for the success of such a transition.

The relevance of a transition of the energy system can be seen in a twofold manner. In order to avoid or at least mitigate negative effects caused by climate change experts recommend a long list of short-term political and technological measures (IPCC [1]). A great number of them are directly related to the way we serve our energy demand today. The second important aspect of energy relates to the fact that fossil fuels are limited and have to be replaced in the future.

Energy supply is of vital interest for end-users too. According to the Austrian Energy Agency households spend more than 10 billion Euros per year for energy needs. Within the last five years the energy demand of private households has increased extraordinarily. In addition, climate change has recently become a problem of great public concern and people are aware, that there is a need to change their behaviour. Beyond doubt this high level of public awareness concerning energy was a good precondition to run a participatory process.

This paper reports on a research project funded by three public sponsors: (1) the Austrian Council for Research and Technology Development (RFT), an advisory body to the Austrian Federal Government; (2) the Federal Ministry of Transport, Innovation and Technology (BMVIT) and (3) the Federal Ministry of Economics and Labour (BMWA). The Austrian Council is particularly interested in the project from a technological and research policy perspective. As outlined below in more detail (section 2), the Austrian Council has a role to play in formulating research agendas and wants to do so in the future not only with the help of experts and stakeholders, but is curious to experiment with participatory methodology involving laypeople. At the same time, it sees participatory events as a means to foster awareness of innovation and technology. By contrast, the two ministries joined their forces amongst other things with regard to support research and development in energy technologies and started together in 2007 the research programme "Energy of the Future" (see below in section 3). Their interest in our project is therefore a direct input into future calls of the programme.

We developed a tailor-made process (described in more detail below in section 4) that will give answers both to the questions of the Austrian Council and the needs of the ministries. While the former mainly wants to know whether our experiment can serve as a model for future involvement of citizens, what effect the conference had on the perception of those involved, and how the process was perceived in public, the latter are mainly interested in having their 
concept put in perspective, in supplementing ideas, in adding new perspectives and in receiving user-centred input with regard to their programme. Hence we devised several phases of the process, including a feedback and evaluation phase after the main event.

Selected results of the pTA are presented in section 4.3 , focussing on the energy technology related outcomes of the citizen's conference.

\section{Participatory TA in the Austrian context}

In the context of research and technology policy we frequently face conflicts of values. These conflicts as well as, to some extent, conflicts of knowledge and interests, are perhaps not capable of being solved. Nevertheless, they can be negotiated more transparently, comprehensively by holding a structured dialogue involving citizens (laypeople) who have not previously participated, alongside experts and stakeholders. Thus, there is a chance to arrive, on the one hand, at better decisions, as this would incorporate, on a broader base, knowledge, interests and value judgements; and on the other hand, decisions would be better legitimised. These proposed procedures take effect alongside the established decision-making processes; they extend the decision base but are not intended as a substitute for those processes (Nentwich et al. [2]).

While there is a tradition of involving stakeholders - in particular the social partners in all kinds of policy formulation including technology policy -, performing technology assessment (not in the classical expert-oriented manner, but with participatory methodology) has never been widespread in the Austrian context so far. An internationally comparative study at the European level in 2000 (Belucci et al. 2000, published as (Joss and Bellucci [3])) included only a few examples from Austria, not all of which actually involving laypersons, but also stakeholders. The record so far includes two consensus conferences, one on tropospheric ozone in 1997 (Torgersen [4]), the other on genetic data in 2003 (Bogner [5]); the EUROpTA report also describes an interesting stakeholder participation process leading to the Austrian technology Delphi 1996-98 (Aichholzer, Cas et al. [6]) and the Salzburg Traffic Forum in 1995/96.

Furthermore, a number of experiences with participatory processes have been made in particular in the environmental sector. On the one hand those participatory events have been made within formal activities, for instance in the framework of strategic environmental impact assessment procedures. On the other hand informal endeavours have been carried out in the framework of various research projects. Examples cover ecological building concepts (Ornetzeder [7]), smart home technology (Rohracher [8]), or ecological sanitation technology (Starkl, Ornetzeder et al. [9]). In those cases new technological options have been discussed and evaluated in focus groups by different types of users.

In the particular context of TA the focus was hitherto on stakeholder and expert involvement. More recently an increasing practical interest in including pTA elements in current projects have been implemented, such as the EU project PRISE (Jacobi and Holst [10]), in which lay persons assessed different scenarios 
of futures with privacy enhancing or threatening security technologies and in particular the project reported in more detail in this paper.

\section{Focus of the pTA project: energy research in Austria}

In Austria, energy research funded by public authorities became more and more mission-oriented in the 1990s. In 1999 the Federal Ministry of Science launched the first Austrian Programme on Technologies for Sustainable Development, originally slated for five years. Although the main focus of this programme was on technological development the authors designing the programme were, however, aware that they would have to seek approaches oriented not only on technological criteria. Research and development with the goal of sustainable development, they have argued, requires balancing a variety of interests. For the first time a research and development programme in Austria called not only for innovation in the field of technology, but also was open for socio-economic aspects. As defined within this first programme, sustainability should refer to the following:

- An increasingly efficient consumption of energy with respect to the entire life cycle

- A greater use of renewable sources of energy (especially the use of solar energy)

- The greatest possible use of organically renewable raw materials as well the efficient use of materials

- And increased attention to service and use from users' point of view (BMWF [11]).

In 2004, based on several years of experience and more than 200 funded research projects, the responsible department within the meanwhile unlabelled Ministry of Transport, Innovation and Technology (BMVIT) started activities to develop a follow-up programme. Within these activities (Austrian Strategy Finding Process ENERGY 2050) a broad range of experts and relevant stakeholders had been invited to discuss requirements for a new research programme. In this preparatory phase it was important to develop long-term strategies and measures along with adequate research goals aiming at the transformation of the existing energy system within the next 40-50 years. Compared to the first programme in this case mitigation of climate change turned out to be the major force behind the reorientation of the Austrian energy research agenda (BMVIT [12]).

The following programme "Energy of the Future" which was launched in 2007 aiming at energy efficiency, the improvement and development of renewable energy technologies and the design of smart energy networks (BMVIT [12]). The programme was subdivided into seven research areas, whereof one was focused on energy and consumer. Research projects in this area should contribute e.g. to the development of new or significantly improved home devices (like new lightning systems, micro-CHP, solutions to avoid stand-by losses or smart meters) or to the design of completely new systems to provide energy services on the household-level. Beside projects with a technological 
focus the programme supported research concentrating on organisational aspects of energy and the behaviour of users too. Examples for this kind of socioeconomic research cover models for energy contracting or leasing, new concepts for information and education or the interrelation of energy demand and lifestyles.

Although end-users of energy - as addressees - play a very prominent role within the programme, laypeople have not at all been involved in the preparatory process. Therefore this lack of direct contact between energy experts and endusers served as one of the starting points for the presented pTA project.

\section{The Conference on Future Search \& Assessment}

The overall aim of the future search \& assessment conference was to invite laypeople and reflect on selected topics from the research programme "Energy of the Future". Furthermore the conference should have given the public the opportunity to be involved in the development of a research agenda - by means of the participants as well as through the media. Citizens should have had the opportunity to learn more about ongoing research and development in the field of sustainable energy technology but also to influence the direction of activities. However, to deal with such objectives is quite uncommon in the Austrian context.

Given the technological complexity and comprehensiveness of the research programme it was clear that it would not be possible to present all details to the participants. Rather the challenge was to give an overview of the genesis and purpose of that programme and discuss only those issues that more or less relate directly to end-users. In order to reduce complexity and variety we decided to select five research topics previous to the main event. In the preparatory phase it also turned out that we could not focus on specific research issues without discussing the wider socio-political context of sustainable development. Laypeople should have been able to raise common-good issues as well as more individualistic arguments.

In order to meet these requirements we chose the following 3-step approach:

1. A preparatory workshop to reduce the number of 11 possible topics down to 5 to be addressed within the following pTA conference

2. A two-day future search \& assessment conference with 30 to 40 laypeople and seven external experts concerning three main points: (a) discussion of relevant aspects underlying the long-term visions ("Leitbilder") for the future of energy research, (b) assessment of five specific energy and end-user related research topics in detail; and (c) presentation of main results and participants' experiences within a conference for stakeholders and energy experts on behalf of the programme initiators.

3. A follow up ex-post survey of the participants to track potential effects as a consequence of the citizens' conference. 


\subsection{Preparatory workshop}

As a first step to broadly embed the programme design within the end-users' perception, a three-hour preparatory workshop was held at the end of September 2007. The main idea was to confront the general public in an exploratory manner with the research agenda and discuss and finally prioritise the presented topics. For this aim three different social groups were invited: end-users ( 3 participants representing diverse lifestyles), representatives of consumer organisations (3 persons), and journalists (5 journalists with experiences in energy issues). Following the workshop outcomes the project-team selected, in cooperation with the sponsors, five topics to be presented and discussed at the main event. Table 1 gives a short overview on the selected topics, each with brief definitions.

Table 1: $\quad$ Selected research topics to be discussed at the conference

\begin{tabular}{|c|c|}
\hline Research topics & Brief description \\
\hline Micro-CHP & $\begin{array}{l}\text { "Micro Combined Heat and Power" is the simultaneous production } \\
\text { (cogeneration) of heat and electricity in individual homes. Effectively the } \\
\text { micro-CHP unit replaces the central heating boiler and provides heat, hot } \\
\text { water and the majority of the home's electrical needs ("power station for } \\
\text { every household"). First marketable products are already available. Research } \\
\text { could help to improve existing technology. }\end{array}$ \\
\hline $\begin{array}{l}\text { New system } \\
\text { solutions and } \\
\text { avoidance strategies }\end{array}$ & $\begin{array}{l}\text { Research in this field should completely explore new ways to provide } \\
\text { various energy services on the household-level. Such systems have to be } \\
\text { significantly more effective than current practices. System solutions could be } \\
\text { realised through miniaturization of devices and/or through the integration of } \\
\text { functions into larger units (e.g. by the use of ventilation systems for heating } \\
\text { and cooling purposes). }\end{array}$ \\
\hline $\begin{array}{l}\text { Smart metering and } \\
\text { „intelligent“" end- } \\
\text { user equipment } \\
\text { (IRON) }\end{array}$ & $\begin{array}{l}\text { A smart meter is a type of advanced electrical meter that identifies } \\
\text { consumption in more detail than a conventional meter; generally, it } \\
\text { communicates this information via a network back to the utility for } \\
\text { monitoring and billing purposes (telemetering). Integral Resource } \\
\text { Optimization Network (IRON): Electric appliances are equipped with an } \\
\text { "IRON-box" that provides information on future energy demands to } \\
\text { electricity suppliers. Intelligent end-user equipment enables load } \\
\text { management. }\end{array}$ \\
\hline $\begin{array}{l}\text { Innovative } \\
\text { contracting and } \\
\text { leasing models }\end{array}$ & $\begin{array}{l}\text { Energy contracting (and leasing) comprises different forms of energy } \\
\text { services with main emphasis on the use of energy saving procedures and } \\
\text { efficient technologies. The main focus is on a contractual relation between an } \\
\text { energy provider (contractor) and its customer (energy consumer). While } \\
\text { contracting and leasing is quite common in industry, the public sector } \\
\text { products for end-user markets have to be developed. }\end{array}$ \\
\hline $\begin{array}{l}\text { Visualization and } \\
\text { monitoring of } \\
\text { energy use }\end{array}$ & $\begin{array}{l}\text { The aim in this field is to visualize the energy consumption of single } \\
\text { appliances and/or of a household. It could be displayed directly on the device } \\
\text { itself or on a central unit, e.g. on a PC. The presented information may relate } \\
\text { to the current consumption and/or to a specific period, such as a year. } \\
\text { Visualization of the energy consumption could contribute to the dealing of } \\
\text { energy in a more conscious way and and/or shed light on weak points. }\end{array}$ \\
\hline
\end{tabular}




\subsection{Selection of participants}

In order to obtain representative results we decided to select participants for the main conference on the basis of a controlled quota sample, roughly typifying the Austrian population. A specialized social research institute conducted the recruiting process. A large number of interviewers all over Austria informed potential participants in short face-to-face interviews.

Conditions for attending the conference included the following: an allowance of $€ 200$ for attending the two days, travel costs and accommodation for those not from Vienna, free meals and coffee breaks.

In terms of the accountability of the process, the participants were informed at a very early stage that their personal contribution will have an indirect effect in so far as the programme makers and the decision makers are (a) interested in the results and (b) will be given that information in terms of an instantaneous presentation the very next day and of course in an evaluated way in terms of further proceeded reports. It was made clear that the citizens' contribution would be of great value and a necessary precondition for the further development of the energy research agenda.

The recruiting process was successful in terms of the absolute number of participants as well as of the structure of the sample. In the end 36 laypeople from all over Austria attended the conference.

\subsection{Recommendations for the energy research agenda}

On the second day of the conference five end-user-oriented research topics were discussed in detail. Table 2 gives an overview of selected results. Generally, it is important to mention that in spite of some critical discussions the involved laypeople approved of the presented technologies (or subjects) as meaningful approaches to transforming the existing energy system towards sustainability. Based on that general agreement a number of detailed recommendations for each research topic were formulated.

The list of recommendations embodies both requirements related to general aspects of social acceptability as well as requirements derived from more individual orientations. For most of the general requirements we can see a strong connection to the common "Leitbild", which was developed on day 1 . All of the discussed research topics are considered to be useful contributions in reaching the desired ecological goals - most importantly finding strategies to address the challenges of climate change. The discussed technologies should be as efficient as possible and based on renewable energy sources only. Moreover they should be treated as integrated parts of larger socio-technical systems. Unsurprisingly such recommendations match up well with the guidelines from the programme "Energy of the Future" and the laypeople's "Leitbild". In this case citizens have more or less confirmed already agreed strategies and programmes. In doing so, laypeople have contributed to the social robustness of these goals and related measures. 
Table 2: $\quad$ Selected researchorientated recommendations by laypeople

\begin{tabular}{|c|c|}
\hline Research topics & Recommendations by laypeople \\
\hline Micro-CHP & $\begin{array}{l}\text { - Micro-CHP should support the energy-independence of households } \\
\text { - Devices have to be affordable in purchase and maintenance } \\
\text { - Use of regionally available, renewable resources is important } \\
\text { - Technology should be improved as part of a larger system (e.g. in } \\
\text { accordance with available renewable fuels) } \\
\text { - Stirling engine and fuel cell technology to be used on the household- } \\
\text { level are a high priority } \\
\text { - Research should aim at highest possible energy efficiency and the } \\
\text { ability for effective power-management (micro-CHP as part of virtual } \\
\text { plant) }\end{array}$ \\
\hline $\begin{array}{l}\text { New system solutions } \\
\text { and avoidance } \\
\text { strategies }\end{array}$ & $\begin{array}{l}\text { - } \quad \text { Focus on saving resources and foster awareness for resources } \\
\text { - } R \& D \text { should lead to concrete outcomes (e.g. sponsorship for } \\
\text { ecological housing) } \\
\text { - The research programme should be aware that involved social players } \\
\text { (e.g. architects, planners, handcrafter, users) represent different } \\
\text { perspectives which should be included } \\
\text { - Results of research should be actively disseminated } \\
\text { - Social aspects should be taken into account }\end{array}$ \\
\hline $\begin{array}{l}\text { Smart metering and } \\
\text { „intelligent“" end-user } \\
\text { equipment }\end{array}$ & $\begin{array}{l}\text { - Presented information should be simple and plain (in order to support } \\
\text { changes in attitude and raising awareness for natural resources) } \\
\text { - Data security should be guaranteed (concerning recording, } \\
\text { interpretation and transmission) } \\
\text { - Households should profit in financial terms (e.g. by automatic } \\
\text { - } \text { selection of lowest tariff) }\end{array}$ \\
\hline $\begin{array}{l}\text { Innovative contracting } \\
\text { and leasing models }\end{array}$ & $\begin{array}{l}\text { - Offer is attractive for users when expertise of contractor is guaranteed } \\
\text { - Information and recommendations by contractors should be neutral } \\
\text { (non-product related) } \\
\text { - Loss of autonomy should be minimized, contractor should find } \\
\text { - } \quad \text { Provistructive ways to deal with loss of control and autonomy } \\
\text { - Overall energy savings should be guaranteed }\end{array}$ \\
\hline $\begin{array}{l}\text { Visualization and } \\
\text { monitoring of energy } \\
\text { use }\end{array}$ & $\begin{array}{l}\text { - Awareness raising should start as soon as possible (e.g. programmes } \\
\text { for different age-groups, cooperation with communities) } \\
\text { - Usability of monitoring devices is very important (e.g. for the elderly) } \\
\text { - Monitoring devices should enable households to remain independent } \\
\text { from energy suppliers } \\
\text { - Information on energy consumption should be combined with } \\
\text { recommendations } \\
\text { - Connection to social policy issues should be considered }\end{array}$ \\
\hline
\end{tabular}


Compared with the descriptions of end-user related research in the programme "Energy of the Future", the discussions have brought about some new aspects, too. According to the notion of social justice in the "Leitbild", laypeople argued for affordable end-user products and guaranteed energy savings; it was generally agreed that social policy issues should be taken into account more seriously. The prominent role of autonomy - defined as being independent from energy suppliers - and the importance of privacy issues (data security) may also be seen as new and fruitful inputs for the Austrian energy research agenda.

\section{Conclusions}

In this paper we have presented experiences with a recently conducted participatory TA process on energy research in Austria. The recently launched research programme "Energy of the Future" served as starting point and subject matter. The main idea of the tailor-made participation process was to combine elements of vision assessment with an innovation-oriented TA approach. In this case, citizens were involved in the development of a research agenda for the first time. Within the conference we provided comprehensive up-to-date information about energy research and citizens had the opportunity to reflect on long-term strategies as well as concrete technologies or energy services. Another goal was to uncover and make use of everyday experiences and attitudes of laypeople as end-users of energy. In other words it was the attempt to assess technology at a very early stage of development.

As the results show laypeople clearly support the idea of mission-orientated innovation policy. Research and development in the energy sector should lead directly to solutions to mitigate climate change. Citizens are very aware that problems of the future cannot be solved by technological innovation alone. New technology therefore must be embedded in wider socio-political contexts such as changed price relations and new consumption patterns. The ranking of different political targets made clear that the principal orientation of the Austrian research agenda is widely supported by the general public. However, energy policy should seriously consider social issues as an integrated part.

The chosen conference design made it possible to discuss various aspects of future technology in detail. Laypeople came up with a list of recommendations covering general aspects of social acceptability as well as requirements derived from more individual orientations (e.g. aspects of usability). All in all the conference produced a broad range of recommendations and a considerable number of new aspects came to light. The results represent an interesting input for the development of the Austrian energy research agenda.

\section{Acknowledgement}

This research was funded by the Austrian Council for Research and Technology Development, the Federal Ministry of Transport, Innovation and Technology and the Federal Ministry of Economics and Labour. We would like to thank Wolfgang Gerlich for valuable advice and doing a professional job as main 
facilitator. We also like to thank Barbara Schmon, Michael Hübner, Monika Auer, Peter Molnar, Lothar Rehse, Friederich Kupzog, Georg Benke, Karen Kastenhofer, Ulrich Fiedeler, André Gazo and 36 persons from all over Austria.

\section{References}

[1] IPCC, Ed. (2007). Working Group III contribution to the Intergovernmental Panel on Climate Change, Fourth Assessment Report, Climate Change 2007: Mitigation of Climate Change. Geneva.

[2] Nentwich, M., A. Bogner, et al. (2006). Techpol 2.0: Awareness Partizipation - Legitimität. Vorschläge zur partizipativen Gestaltung der österreichischen Technologiepolitik; Endbericht September. Vienna, Rat für Forschungs und Technologieentwicklung.

[3] Joss, S. and S. Bellucci, Eds. (2002). Participatory Technology Assessment. European Perspectives. London, Centre for the Study of Democracy.

[4] Torgersen, H. (1999). The Ozone Consensus Conference in Austria. Case Study for EUROpTA. Vienna, EUROpTA.

[5] Bogner, A. (2004). Partizipative Politikberatung am Beispiel der BürgerInnenkonferenz 2003 (Analyse); final report, sollicited by: Rat für Forschungs- und Technologieentwicklung. Vienna.

[6] Aichholzer, G., J. Cas, et al. (1998). Technologie Delphi Austria; 3 volumes: I: Konzept und Überblick; II: Ergebnisse und Maßnahmenvorschläge; III: Materialien.

[7] Ornetzeder, M. (2003). Sustainable technology and user participation. Assessing ecological housing concepts by focus group discussions. Culture, Environmental Action and Sustainability. R. G. Mira, J. M. S. Cameselle and J. R. Martinez. Cambridge and Göttingen, Hogrefe \& Huber: 145-160.

[8] Rohracher, H. (2006). "Sustainability as a matter of social context: information technologies and the environment." International Journal of Environmental Technology and Management 6(6): 539-552.

[9] Starkl, M., M. Ornetzeder, et al. (2007). "An Integrated Assessment of Options for Rural Wastewater Management in Austria." Water Science \& Technology 56(5): 105-113.

[10] Jacobi, A. and M. Holst (2007). Privacy enhancing shaping of security research and technology, European Commission.

[11] BMWF, Ed. (1999). Konzept Impulsprogramm Nachhaltig Wirtschaften. Vienna.

[12] BMVIT, Ed. (2007). Diskussionspapier. Strategieprozess ENERGIE 2050. Zwischenstand zum Forschungsprogramm. Wien. 


\title{
Negotiating the local embedding of socio-technical experiments: A case study in fuel cell technology
}

\author{
Anna Schreuer*, Michael Ornetzeder** and Harald Rohracher* \\ * Inter-University Research Centre for Technology, Work and Culture, Graz, Austria \\ ** Institute of Technology Assessment, Austrian Academy of Sciences, Vienna, Austria
}

\begin{abstract}
Transitions towards more sustainable socio-technical regimes crucially depend on processes of social learning. This paper focuses on the process of selecting and setting up technology learning experiments at the municipal level. It reports on experiences using a Constructive Technology Assessment (CTA) approach to identify and evaluate potential deployment projects in the area of fuel cell technology in Graz, Austria. The results highlight that dialogue processes between $R \& D$ actors, municipal actors and intermediary organisations serve well for the identification of suitable niches for socio-technical experiments. However, for the actual implementation of such experiments the limited room for manoeuvre of municipalities and the importance of the coordination of various governance levels need to be taken into account. In particular, tensions may arise between overarching technology policy goals defined at the national level and problem-based approaches applied at the municipal level based on prevalent local issues and needs.
\end{abstract}

Keywords: technology learning; municipalities; fuel cells; CTA; Strategic Niche Management

\section{Introduction}

It is widely acknowledged that the introduction of new technologies requires social learning processes, especially when this entails changes at a system level, as it is the case with new energy and transport technologies. A number of questions arise around issues such as the deployment of supporting infrastructures, the organisation of value chains, the institutional embedding and regulations concerning these new technologies or the development of new patterns of use. 
Relatively little attention has so far been given to the specific contexts and locations of such technology learning processes as well as to the processes of systematically identifying and selecting experiments and pilot projects at the municipal level. Hodson and Marvin (2009) have recently drawn attention to cities as important actors and mediators in technological transition processes. Some other authors (Van den Bosch et al. 2005, Vergragt and Szejnwald Brown 2007) have highlighted the specific potentials of the municipal level as a setting for early technology learning processes. In this paper we investigate these potentials further by presenting results from a case study on the identification and assessment of municipal strategies and experiments in the area of fuel cell technology in Graz, Austria. By reporting and reflecting on a workshop series that was set up to discuss and assess potential contexts of fuel cell applications at the municipal level, we also address issues such as possible roles of the municipality in technology learning processes, tensions between differing rationales at different governance levels and a number of pragmatic issues that need to be taken into account in setting up niches for learning processes at the municipal level.

The structure of the paper is as follows: The following section introduces the concept of Constructive Technology Assessment (CTA), which was used as a reference framework for the process. Section three then addresses the specific potentials and challenges of the municipal level as a place for technology learning processes. The actual case study is presented in section four. Section five then both discusses the results from the workshop series and evaluates the chosen workshop format. Finally the conclusion draws together the most important points of the paper.

\section{Participatory technology development and assessment}

Transitions to more sustainable technology regimes are heavily dependent on processes of social learning. Social learning always plays a role in technological development since social players actively and sometimes unknowingly shape the design of new technologies. Moreover, new social practices around the use of new technologies have to be developed, institutional contexts have to be adjusted - in short, the development and implementation of 
technologies requires a co-evolution of social and technical elements. With sustainability as a somewhat vague but demanding and often controversial guiding vision, social learning processes become even more important.

A number of concepts and methodologies have been developed to understand and facilitate social learning processes in ongoing technology developments. For our own work on the sustainability of fuel cell technology we have chosen the approach of Constructive Technology Assessment (CTA) as a methodological framework. Focusing on the potentials of fuel cells in local use contexts at the municipal level, CTA offers valuable insights on social learning processes and the importance of protected spaces for the management of sustainable transitions.

The approach of CTA aims at broadening the decision-making process on technological development and considering impacts already during the development of the technology by bringing together a manageable variety of relevant parties. Designers, users, citizens as well as policy makers should be able to articulate ideas and values quite early and negotiate and renegotiate important aspects throughout the course of the technology development process (Rip et al. 1995, Schot and Rip 1997, Schot 2001). CTA seeks to open the design process at early and/or promising stages in order to learn about possible - negative as well as positive impacts of the new technology before they become entrenched and possibly negotiate alternative development pathways.

Schot (2001) has specified three general principles that define CTA activities. CTA (1) should advance the capacity to anticipate impacts of future technology (anticipation), (2) it should improve the ability of social actors to consider technology design and social design as one integrated process (reflexivity), and (3) it should enable societal learning. Designers, future users, and other relevant social actors should have the opportunity to question their own presumptions and come to new specifications. While first-order learning refers to the ability to articulate user preferences and regulatory requirements and to connect such conclusions to design features, second-order learning means to question existing preferences and requirements in a more fundamental way, to reflect on the roles of various 
stakeholders and maybe to come up with quite different demands, radical design options or new application contexts (Grin and Van de Graaf 1996).

A specific approach to support technology learning processes within the framework of CTA is strategic niche management (SNM). SNM (see e.g. Hoogma et al. 2002) refers to the creation and nurturing of protected spaces for promising technology to facilitate ongoing interactive learning of the actors participating. A central aim of the development of niches is to learn in realistic use contexts (e. g. market niches, controlled field experiments) about needs, problems and possibilities connected with the technology experimented with, and to help articulate design specifications, user-requirements or side-effects of the innovation. Managing the development of environmental technologies in niches involves organising social learning processes with actors such as producers, technology designers and users in a joint process. Niches have also been studied as local experiments at the municipal level (see Raven et al. 2008), as examples of societal embedding (Kivisaari et al. 2004) or as 'bounded socio-technical experiments' (e. g. Szejnwald Brown 2008, 2003). However, critical voices also emphasise that niches, such as passive houses, have rarely been set up or managed in a straightforward and planned way (Lovell 2007, Smith 2007).

Given the importance of niches for strategic learning processes about the context of application and use of new technologies such as fuel cells it is rather striking how little attention has so far been paid to the selection of such pilot applications. Not only should such niches be of long-term strategic importance for the transformation of urban infrastructures, but they should also link-up with the needs, competencies and expectations of local actors. This initial phase of identifying and selecting possible options for fuel cell pilot projects was at the centre of a project that will be presented in this paper. Informed by the basic ideas of SNM regarding the selection, preparation and set-up of niche experiments, a workshop series was organised where a variety of stakeholders first identified plausible application areas and then critically discussed requirements for pilot projects in these areas at the municipal level. Before presenting this case study the following section will briefly raise 
some general issues concerning the municipal level as a place for technology learning processes.

\section{Technology learning processes at the municipal level}

With respect to technology learning processes the municipal level certainly has specific potentials. Van den Bosch et al. (2005) reporting on a case study on system innovation towards a fuel cell transport system in the city of Rotterdam underline a number of characteristics of cities as the location of technology learning processes. These include a high sense of urgency in relation to specific problem situations (such as transport related problems) and a high concentration of stakeholders in government, industry and research. In addition to that they also note the advantages of initial local, small-scale experiments over the top-down global level.

However, it must be taken into account that these learning processes at the municipal level can be approached from two quite different angles, involving different rationales and agendas. At the national level, technology policy goals and strategy development often dominate. From this perspective local experiments serve to contribute to momentum-building in specific technology areas by finding promising niches for technology testing, building up local actor networks, creating initial markets and learning from shared experiences. This corresponds quite closely to what Karlström and Sandén (2004) have highlighted as the main goals of demonstration projects, namely

- Learning in relation to technology performance and the contexts of use

- Opening up markets, e. g. by increasing public awareness and identifying institutional barriers and

- Formation of a network of actors, which can then evolve into active advocacy coalitions.

This rationale is obviously also well in line with the interests of R\&D actors in the technology field in focus, as such experiments provide them with an opportunity for technology probing, product visibility and initial market development. 
On the other hand, from the perspective of the municipality, the benefit of engaging with technology learning processes will of course be more strongly tied to local interests and needs, such as addressing prevalent problems of the municipality (e. g. local air quality) or strengthening the regional economy by involving regional firms in technology deployment. From this point of view it is not so much an issue of selecting appropriate application areas for a given technology but rather to consider different technical and organisational variants of addressing a particular problem situation.

Nevertheless urban municipalities may in fact also strive for a profile as 'sustainable city' or technology forerunner and therefore become actively involved in the promotion of particular technology areas. Eames et al. (2006) as well as Hodson and Marvin (2009), studying attempts to make London a forerunner of a 'hydrogen economy', find that world cities such as London do actively seek to position themselves as managers of such largescale transition processes. However, in their attempts to become a central player in the promotion of this technology area, they also find themselves in competition with multinational companies as well as EU level governance, framing the role of London merely as a kind of 'test-bed' for technology probing.

Thus, while the potentials of municipal technology experiments are multifaceted, so are the rationales and agendas attached to them. Implementing projects thereby also becomes an issue of negotiating differing problem framings (see also Raven et al. 2008) and coordinating different governance levels (see also Kivisaari et al. 2004). The following case study describes an attempt to actively create a forum for the exchange of the perspectives of different actors, identifying potential technology deployments in the field of fuel cell technology, and for discussing the local embedding of promising options in a municipal context.

\section{Case study on fuel cell technology at the municipal level}

The case study our discussion about opportunities and challenges of municipal technology learning is drawing upon was carried out as part of a practice-oriented research project on the potentials of user and stakeholder involvement in technology development (Ornetzeder et 
al. 2008). It was funded within a national R\&D programme focussing on the development and implementation of 'green' technologies. The case study consisted of some preparative interviews and, as its main part, a workshop series in Graz, Austria, that brought together $R \& D$ actors in the area of fuel cell technology with municipal actors and representatives of intermediary organisations. The workshop series thereby aimed to create a reflexive learning environment for discussing the potentials, problems, and possible impacts of fuel cell technology at the municipal level.

In terms of the framings discussed in the previous section, the case study was thus tied to an overarching rationale concerning the promotion of particular technology fields, predefining the technology field to be explored. On the other hand, however, the explicit aim of the project was to contribute to a more reflexive and locally embedded process of technology development and deployment, applying the basic principles of CTA and SNM.

Broadly speaking, fuel cells are seen to be of interest because they are attributed significant potentials regarding the reduction of $\mathrm{CO}_{2}$ emissions and increased energy efficiency levels. The following subsection will briefly provide some further background on the innovation field of fuel cell technology. In a next step we will outline the conceptualisation and implementation of the workshop series and finally present some central results of the workshops.

\subsection{The innovation field of fuel cell technology}

Since the late 1950ies fuel cells have time and again been the focal point of waves of high expectations, succeeded by phases of disappointment when high striving goals could not be met. Even though most public attention has been attracted to the use of fuel cells as a propulsion technology for vehicles, other major application areas include stationary applications (mostly decentralised energy supply for households, businesses and public facilities as well as off-grid energy supply, e.g. for gauging stations) and portable applications (as a substitute for rechargeable batteries, e. g. in laptops, mobile phones, etc.).

The high expectations with regard to fuel cell technology are to a large extent related to the high ecological potentials associated with it, most notably the potential to reduce 
greenhouse gas emissions. The overall emissions balance, however, depends not only on emissions at the point of use of fuel cells, but also on the emissions generated during the production of the fuel. While currently by far the largest part of hydrogen produced worldwide comes from steam reforming of natural gas, the 'ecological vision' regarding fuel cells, consists of using energy from renewable sources to generate the fuel, e.g. producing hydrogen via electrolysis using electricity from wind or solar energy.

Although fuel cell technology has already reached the level of concrete product developments (prototypes, limited-lot production), production costs are generally still too high for broader market introduction.

While it is hard to predict any long-term developments, it seems however likely that within the next years the application of fuel cell technology will be limited to a number of niche applications. These niches can be expected to develop in areas where fuel cell technology may provide a specific advantage over existing or competing solutions. Some possible examples, referred to by R\&D actors in fuel cell technology during preparatory interviews for the workshop series included fuel cell vehicles in public transport, hybrid utility vehicles (electric and fuel cell driven for industrial sites, airports, hospitals or city cleaning), emergency power supply (e. g. for hospitals or computer servers) and off-grid gauging and transmitting stations.

A number of the application areas referred to thus relate to municipal utilities such as public transport, hospitals or city cleaning and indeed, a number of municipal pilot projects in the area of fuel cell technology have already been introduced in various cities (e. g. HyFLEET:CUTE, 2006-2009, co-funded by the European Commission and private companies, introducing fuel cell busses in the public transport system).

\subsection{Conceptualisation and implementation of workshop series}

The workshop series consisted of three workshops held in the time-span from mid-June to early July 2007 in Graz, a medium-sized city of approx. 250.000 inhabitants in the south of Austria. The city of Graz was chosen for the workshop series since a significant number of Austrian firms and research institutes with R\&D activities in the area of fuel cell technology 
are located in and around Graz. Also, a hydrogen fuelling- and testing-station is located there, set up as a demonstration project in 2005. In addition to that, due to the geographical location of Graz, surrounded by hills, particulate matter emissions pose a serious problem and strategies for the improvement of air quality are of particular importance. The city of Graz is also well known for long standing municipal environmental protection activities.

Prior to the workshops, some preparative interviews with experts in the field of fuel cell technology were conducted. They served both to obtain an overview of the innovation field of fuel cell technology and to identify promising fuel cell application areas in a municipal environment. The interviews provided the basis for a background document sent out to participants of the workshop series, introducing the innovation field of fuel cell technology as well as outlining the planned workshop format. Stakeholders invited to the workshop series included fuel cell experts from basic research and industry as well as municipal actors and representatives of intermediary organisations.

The workshop series was devised as a three-step process and made use of the technique of scenario building and assessment as the basis for strategy development. Thereby the discussion of potential fuel cell applications at the municipal level was situated in a broader context concerning the long-term development of the innovation field. The workshop series followed a design successfully applied earlier by Weber et al. (2005):

- Workshop 1: Identification of framework conditions influencing the future use of fuel cells, development of basic scenarios concerning future fuel cell use

- Workshop 2: Choice of sustainability assessment criteria, qualitative assessment of the strengths and weaknesses of various elements of the scenarios

- Workshop 3: Strategy development at the municipal level, discussing possible pilot projects and formulating general requirements for municipal pilot projects

The three workshops were attended by a total of 16 stakeholders, where participation in individual workshops fluctuated between six and ten participants. The larger part of participants consisted of experts in fuel cell technology (R\&D actors from basic research and industry), while only relatively few actors from the municipality and intermediary 
organisations took part. The workshops followed a bottom-up approach, using various interactive techniques, group work and plenary discussions for developing and assessing the scenarios and for strategy analysis. Table 1 summarises relevant details of the implementation process.

[Insert table 1 here.]

\subsection{Results of the workshop series}

The workshop series produced a number of interesting results on potentials and priorities for the municipal implementation of fuel cell technology, which will be described in this section.

Already during the first workshop diverging interests and problem framings of different actor groups became quite clear. Participants from research, industry and the municipality alike were most strongly interested in discussing short to medium term applications, notably in the form of potential pilot or demonstration projects. Especially industry actors highlighted the potentials of pilot projects to create higher levels of awareness and acceptance of hydrogen and fuel cell technologies. They underlined the need for providing 'positive technology experiences' as well as dealing with security concerns related to hydrogen. One actor also suggested an effect of awareness rising through pilot projects on chances for accessing further venture capital. In some individual cases interests in pursuing specific kinds of pilot projects bolstered this general concern for the promotion of fuel cell technology further. Some actors had previously already been developing concrete plans for projects and thus tried to push their stakes in pursuing these particular project plans further.

Nevertheless R\&D actors were generally quite keen on a broad discussion of the potentials and risks of fuel cells in general, of advantages and disadvantages of particular applications and of their local embedding in the municipal context. A broad agreement could be reached that the largest sustainability gains would be achieved by an introduction of fuel cell technology to the transport system (fuel cell vehicles, e. g. in public transport, municipal utility vehicles, logistics system for transporting goods to the inner city, on the longer term 
also private cars). Also backup systems, such as fuel cell use as a load balance for renewable energy sources, were seen to have a significant potential. Most workshop participants rated the use of fuel cells in stationary power supply as not particularly interesting for municipal applications, although some differences of opinion emerged on this point between different R\&D actors. It was noted that stationary applications currently do not offer significant advantages over conventional systems, both in economic and environmental terms.

This ranking was by and large supported from the side of the municipality and it was pointed out that more attractive alternatives to fuel cells could be found in the area of stationary energy supply. In terms of possible transport applications attention was called to the need for a differentiated judgement of individual projects, mentioning aspects such as technological alternatives and costs as well as highlighting the issue of political timeliness. Pilot projects touching upon areas of highly controversial political debate would stand low chances of being implemented. This was judged to be the case for attempting to implement an access-control system in Graz, only permitting zero-emissions vehicles, e. g. fuel cell vehicles, to enter the city free of charge.

A related point was brought forward in response to a suggestion to introduce a logistics system for transporting goods to the inner city based on electric and fuel cell driven vehicles. As this would require the involvement of a large number of individual people, in particular the suppliers and merchants of inner-city shops, it would certainly entail a high degree of organisational complexity. It was generally acknowledged that for an initial pilot project organisational complexity should be kept at a lower level.

Finally, the definition of the role of the municipality within a pilot project was also found to require special attention. While R\&D actors certainly had some hopes that the municipality may become an important ally for technology deployment projects, it soon became clear that the municipality itself was more inclined to see its role only as provider of a potential 'testbed' for technology deployment. Lacking the sources for financial investment and being relatively far removed from technology policy developed at the national level, the municipality 
appeared to be rather reserved towards taking on an active and formative role in the implementation of pilot projects in the field of fuel cells. As it turned out, none of the discussed options for pilot applications met the actual needs and expectations of the municipality (department of energy) at that time. The workshop therefore does not seem to have set off further niche experimentations or pilot projects as it had originally intended. Nevertheless some mention was made of the possibility of acting as an intermediator between different actor groups. All in all it became clear that multiple possible roles exist for a municipality within local deployment projects (e. g. as a technology user; active developer and driver of certain applications; mediator; etc.) and that not all of them can be expected to be fulfilled in individual projects.

Box 1 summarises the results arrived at during the workshop series concerning relevant application areas and requirements for the local embedding of municipal pilot projects.

[Insert box 1 here]

\section{Discussion}

\subsection{Technology learning at the municipal level}

The results from the workshop series clearly provide us with some lessons on practical issues related to the local embedding of pilot projects that need to be considered during the design and implementation phase.

One of these points is the issue of political timeliness. As mentioned in section 3 , van den Bosch et al. (2005) have highlighted a certain 'sense of urgency', e. g. around transport related problems, as a potentially helpful characteristic of technology learning processes at the municipal level. Nevertheless, our workshop discussions also highlighted that issues standing at the centre of political debate involve the risk of polarisation. So while on the one hand a pilot project should address current problems and relate to the municipality's policy strategies, a project touching upon controversially debated policies may become 'trapped' in 
these debates and stand low chances of being implemented. This risk of polarisation will certainly have to be assessed at the level of each individual case - possibly by conducting a careful evaluation of stakeholder positions at the outset.

Another interesting aspect concerns the cautionary stance of the involved stakeholders towards the involvement of a large number of individual actors in initial pilot projects, due to the high complexity this may involve. This runs somewhat against the notion that pilot projects can serve to mobilise stakeholders from a variety of backgrounds and instead highlights the considerable coordination efforts this entails, such as the alignment of interests of the various actors involved. Thus, in each individual case an appropriate balance will have to be struck between mobilising a sufficient number and well-selected set of stakeholders and containing the complexity of the actor network, which is thereby constructed.

Also, the actors involved in an initial dialogue process, like the workshop series reported on here, cannot necessarily already be seen as part of an emerging actor coalition. In our case, for example, while R\&D actors pushed for the implementation of fuel cell deployment projects, the municipality took on a rather critical position towards the issue. Harborne et al. (2007) report on similar experiences concerning only conditional support of fuel cell technology by bus manufacturers involved in the implementation of demonstration projects. However, the clarification and discussion of different interests and agendas over the course of a workshop series can serve to reflect on and possibly redefine the framing, the purpose and the actor roles associated with technology deployment projects.

This became particularly clear during our workshop series when the multiplicity of possible roles the municipality may take on - or be expected to take on - with respect to pilot projects was discussed. At the most basic level, the municipality may simply take on the role of an early user of a technology, implementing certain applications in municipal utilities, while additional costs are covered by extraneous sources. However, it could also act as a promoter and funding body and - in addition to that - as a policy maker, e. g. incorporating pilot projects in longer-term strategies as well as passing relevant legislation. Even more detailed questions can be expected to arise in the implementation of concrete pilot projects, such as 
issues around ownership and intellectual property rights. In the context of climate change mitigation activities these different roles of municipalities have also been addressed as different modes of governing in municipalities, such as self-governing (e. g. own car fleet), governing by authority (regulations), governing by provision (municipal utilities) and governing through enabling (campaigns and promotion) (Bulkeley and Kern 2006).

Eames et al. (2006) and Hodson and Marvin (2009) have already highlighted diverging expectations concerning the role of the city of London in attempted moves towards a 'hydrogen economy'. As mentioned in section 3, the city's efforts to position itself as an active player in this process contrasted with the perspectives of multinational companies viewing London mainly as a 'test-bed' for technology probing. Nevertheless in our case study the situation appeared to be somewhat reversed. Due to limited budgets and lacking an explicit technology strategy, the municipality appeared to be rather reserved towards taking on any role going beyond that of a simple 'user' of fuel cell technology. Participation in technology trials was seen as a possible option, but taking on the role as a funding body or even central coordinator and promoter for such a project was not regarded as feasible.

These experiences may partly be specific to the situation in Graz. Furthermore, as the workshop series focussed specifically on fuel cell technology, the role of the municipality was already somewhat narrowed down to an evaluator or co-organiser of possible deployment projects in a pre-defined technology area (see section 5.2 for a more detailed discussion). Nevertheless our results suggest that municipalities, especially in small to medium sized cities, may often be lacking the means to provide substantial support and leadership in technology learning processes. As noted in section 3, municipalities are often strongly dependent on higher levels of governance, such as the financial resources allocated to them, explicit technology strategies at the national level as well as relevant policies and institutional frameworks. Yet, this is not to say that the municipal level cannot provide significant impulses concerning the application, regulation and maturation of emerging technologies. Rather, it highlights the importance of the coordination of various governance levels in the context of technology learning processes. Thus, while specific niches for technology learning processes 
can be identified and realised at the local level, these efforts may need to be coordinated with overarching technology strategies, legislation and product standards as well as funding programmes at the regional, national and possibly international level. 


\subsection{Process evaluation - lessons learnt}

The previous subsection has discussed some of our results from the workshop series in relation to general questions concerning technology learning processes at the municipal level. In this subsection, by evaluating the process along the criteria proposed by Schot (2001) for CTA processes, some further conclusions on technology learning processes at the municipal level will be drawn, especially concerning the specific format of workshop series applied in this case study. Since CTA was chosen as a broad reference framework for the workshop series, Schot's criteria of anticipation, reflexivity, and societal learning appear to be quite suitable guidelines along which to evaluate the process.

Societal learning occurred at different levels. First of all the workshop series facilitated an exchange of perspectives between municipal actors and technology developers. In particular, several R\&D actors pointed out that they learned a lot about the perspective of municipalities, the specific demands and visions the city representatives articulated, the technologies they would prioritise, or the specific restrictions of municipalities (lack of financial resources; self-perception as facilitators or users but not as project funders). Thus, technology designers did not so much take home new user specifications but rather learned about the practicalities and also difficulties of implementing technology projects at the municipal level. To a certain extent this can be seen as an instance of second-order learning where technological options need to be rethought in a rather fundamental way in view of realistic use contexts. This process of learning about other perspectives was also true for city representatives, who usually had not been confronted with technology opportunities or the importance of local deployment projects, also for export oriented companies.

Secondly, technology designers evidently could profit from the discussions on relevant application fields for fuel cell technology in municipal contexts. A rather broad and wellfounded agreement could be achieved about worthwhile fields for further demonstration projects and strategic niche management processes, such as fuel cell applications in public transport, municipal utility vehicles or logistics systems for transporting goods to the inner city. These prioritised fields could integrate a number of perspectives: the problem situation 
of the municipality, the interest of technology suppliers (e. g. demonstrating specific strengths of the technology, potential for up-scaling markets) and sustainability requirements. Thirdly, the workshops also provided a platform where participants established new contacts and developed plans for further collaboration. While this aspect has not been evaluated systematically, there is at least anecdotal evidence of some joint project proposals and meetings between companies and representatives of the municipality and intermediary organisations resulting from the contacts made in the workshops.

Nevertheless, it must be stressed again that while the time frame and limited resources of a research project were sufficient to start a process of learning and reflection, it has not been successful in kicking off new pilot projects or niche management processes. Some R\&D actors participating in the workshop series did express their interest in having a more continuous platform to interact with municipalities and to develop demonstration projects in close cooperation with municipal and other demand side actors. However, it appears quite likely that these ideas will not be implemented at all or the system-oriented view will split up again into isolated technology demonstration projects without further process facilitation.

In terms of anticipation the workshops also showed some interesting results. Both technology developers and municipal actors were initially rather reluctant to develop future scenarios for the use of fuel cell technology and instead pressed for a direct discussion of projects that could be realised in the short to medium term. Nevertheless the workshop series was in the end quite successful in kicking-off debate about sustainability aspects of fuel cell technologies and about different socio-technical scenarios and trajectories for future developments of the field. As a result, some well-informed and comprehensive miniassessments were produced in a quite short period of time. For technology designers it became clear that sustainable innovation is a rather complex process taking a variety of factors into account and that the question whether fuel cell technologies are contributing to a more sustainable energy system heavily depends e. g. on the assessment of alternative solutions, the relating infrastructure as well as specific local conditions. 
In this sense the process also contributed to the reflexivity of the actors participating in the workshops and was helpful to embed their short-term interests into broader perspectives.

However, despite the successful anticipation and reflection of fuel cell implementation projects at the municipal level, the absence of practical implementation following up these discussions seems to be due to inherent tensions between the municipal and national problem framing, as pointed out in the introduction. While the municipality was interested in solving practical environmental or transport-related problems irrespective of the specific means to be employed, the CTA process, emerging from a national technology policy problem frame, had a strong technology bias, which appears to be inherent in any CTA-type process. These contradictory positions could not be productively overcome in the workshop process. Exploring the societal context and local embedding of a particular technology within a participatory process does indeed open up the innovation process to a broader set of stakeholders. At the same time, however, it also limits the problem horizon to the specific technology under focus, isolating it from technological or organizational alternatives. Moreover, especially in the case of a rather generic technology like fuel cells, a variety of different application areas may exist, which relate to quite different groups of demand side actors, implementation contexts and alternative solutions. Thus, while the workshop did create a forum for the exchange of perspectives of different actors, the technology bias could not be sufficiently overcome.

This became apparent in a number of respects. First of all, the workshop series suffered from a relatively low participation rate of municipal actors. This may partly be attributed to the preparation phase of the workshop series, where higher efforts were put into mapping the technology and its applications than in mapping and articulating demand. Secondly, the emphasis on the mapping of the innovation field in the preparation of the workshop series also had implications for the focus of the workshop that turned out to be more attuned to the interests of technology developers than to the problems and needs of the municipality. Thirdly, pre-defining the technology to be discussed to some extent also pre-defined the possible roles of different workshop participants. Thus, while R\&D actors could try to use the 
workshop series for promoting 'their' technology, the role of municipal actors in the discussions was too often restricted to that of a commentator and potential recipient of fuel cell deployment projects.

These experiences draw attention to the intricate problem of achieving a balanced framing when bringing together different interests and agendas into a joint discussion forum. As Raven et al. (2008) have noted: 'The types and methods that are mobilized, the questions asked (by whom), the timing of their mobilization, and the alignment of social interests and the concomitant resources that they draw on highlight the politicized extent of participatory methods that are often viewed as depoliticized and neutral.' (p. 467)

Reversing the process and taking the problem situation of the municipality as a starting point for technology learning processes would certainly also be a promising approach and resolve some of the problems encountered in this case study. However, it is likely to open up new questions concerning the coordination with national technology policy goals or simultaneous access to a variety of different technology fields. It would not resolve the dilemma of bringing together the different agendas but also competences of local actors, national technology policy as well as researchers and industry actors. What remains is a basic 'dilemma of alignment': Regardless of the starting point that is chosen - either a technology field or a local problem situation - the problem framing this entails is likely to constrain the mobilisation and contribution of actors from 'the other side'.

However, future projects with similar objectives may strive to work more symmetrically in terms of mapping the interests and perspectives of municipal actors in the preparation phase of a dialogue process and leaving more space for alternative technologies or social arrangements. If the starting point is to work from a particular technology field, greater efforts need to be put into matching technology potentials with existing problem situations and identifying interested demand side actors within municipalities before the actual meetings are organised (see also Kivisaari et al. 2004). From a broader perspective, long-term partnerships between municipalities and intermediary organisations that provide more 
continuity in exploring suitable 'green' technologies may constitute an interesting possibility to be explored.

\section{Conclusion}

Technological innovation certainly plays an important role on the way towards a more sustainable society. In order to make this happen, it was often argued, a new paradigm to manage technology development is needed, a more reflexive approach based on broad and to some extent open learning processes and practical experimentation.

In this paper, we have focused on some preconditions to systematically set up technology learning strategies at the municipal level. We have argued that despite the huge potential of cities for creating locally defined technology niches and stimulating social learning processes in real-world experiments, relatively little attention has so far been given to the process of setting up and locally embedding such niches and to the opportunities and specific problems this entails.

In accordance with similar findings the experiences in our case highlight that the preparation of technology learning processes at the municipal level needs to take into account the limited room for manoeuvre of municipalities as well as the importance of the coordination of various governance levels. Municipalities, even if they see themselves as technology forerunner, are limited in terms of funding as well as relevant policies and institutional frameworks. Furthermore, when dealing with technology learning at the municipal level, it is important to be aware of the multiplicity of roles a municipality may take on in a technology learning process; as early user of a technology, as a promoter and funding body, as a policy maker considering longer-term strategies as well as passing relevant legislation, or eventually a combination of these different roles. However, to cooperate with municipalities in pilot-projects or similar niche experiments in any case involves the risk to become part of a political debate with an uncertain outcome. Also, while municipal technology learning projects can serve to mobilise stakeholders and thus shape new actor coalitions in the respective innovation field, the effort of coordinating a possibly large number of actors also needs to be taken into account. 
The internal evaluation of the process indicates that the applied workshop design was capable to encourage the anticipative, reflexive and societal learning capacities of the actors involved. The workshops facilitated substantial exchange of perspectives, especially between the municipality and technology developers, and provided a platform to establish new contacts and develop plans for further collaboration.

However, some structural shortcomings also constrained the process of technology learning and the wider impact of the workshop series. Two main problems emerged, namely the problem of achieving long-term continuity of such an intervention process and the problem of the technology bias that is easily inherent in CTA-type processes. In the context of municipal technology learning, the latter problem is closely related to conflicting approaches that may be taken on the subject - either starting from a particular technology area and attempting to contribute to technology learning and momentum building around the technology in focus - a problem perspective which is often adopted by national R\&D programmes -, or working from the needs and problem situations of the municipality and exploring different technological and organisational solutions. This results in a 'dilemma of alignment' - with the actors and agendas prevalent in this initial framing easily dominating the other side, which is merely considered as the 'context' of the process.

In spite of all these challenges the municipal level clearly offers a huge potential for technology learning processes. For many reasons (e. g. relevant infrastructure, concentration of stakeholders, clearly defined boundaries, etc.) municipalities could be seen as 'natural' niches for exploring new technologies in realistic use contexts on a limited scale. At the same time municipalities can profit from environmental and economic benefits from experimenting with 'green' technologies. Future research in this field could deepen our understanding of the necessary conditions at the outset of technology learning experiments at the municipal level, the multiplicity of roles and competences of municipalities, the possibly unavoidable political character of technology in this context, and the way technology learning is embedded and linked to other governance levels. 
Acknowledgements: The research presented within this paper was funded by the Austrian Federal Ministry of Transport, Innovation and Technology within its programme 'Factory of Tomorrow. We thank Halina Szejnwald Brown and Philip Vergragt as well as two anonymous referees for comments on earlier versions of this paper. 


\section{References}

Bulkeley, H., K. Kern. 2006. Local Government and the Governing of Climate Change in Germany and the UK. Urban Studies 43 No. 12: 2237-2259.

Eames, M., W. McDowall, M. Hodson, S. and Marvin. 2006. Negotiating Contested Visions and Place-Specific Expectations of the Hydrogen Economy. Technology Analysis \& Strategic Management 18, Nos. 3 / 4:361 - 374.

Grin, J. and H. v. d. Graaf 1996. Technology assessment as learning. Science, Technology \& Human Values 21 No. 1: 72-99.

Harborne, P., C. Hendry and J. Brown. 2007. The Development and Diffusion of Radical Technological Innovation: The Role of Bus demonstration Projects in Commercializing Fuel Cell Technology. Technology Analysis \& Strategic Management 19 No. 2: 167-187.

Hodson, M. and S. Marvin. 2009. Cities mediating technological transitions: understanding visions, intermediation and consequences. Technology Analysis \& Strategic Management 21: 515-534.

Hoogma, R., R. Kemp, J. Schot, and B. Truffer. 2002. Experimenting for Sustainable Transport: The approach of Strategic Niche Management. London and New York: Spon Press.

Karlström, M. and B.A. Sanden. 2004. Selecting and Assessing Demonstration Projects: the Case of Fuel Cells and Hydrogen Systems in Sweden. Innovation: Management, Policy and Practice 6, No. 2: 286-293.

Kivisaari, S., R. Lovio and E. Väyrynen 2004. Managing experiments for transition: examples of societal embedding in energy and health care sectors. In System Innovation and the Transition to Sustainability: Theory, Evidence and Policy, ed. B. Elzen, F.W. Geels and K. Green, 223-250. Cheltenham UK: Edward Elgar.

Lovell, H. 2007. The governance of innovation in socio-technical systems: the difficulties of strategic niche management in practice. Science \& Public Policy (SPP) 34(1): 35-44.

Ornetzeder, M., A. Schreuer, S. Weinfurter, J. Feichtinger, H. Rohracher, H. Loibl, A. Eder and S. Strobl 2008. Open Innovation. Instrumente und Strategien zur aktiven Einbeziehung von Nutzerlnnen und anderen relevanten sozialen Gruppen in technische Innovationsprozesse am Beispiel Brennstoffzellen-Technologie und Wood-Plastic Composites. Vienna: BMVIT

Raven, R.P.J.M., E. Heiskanen, R. Lovio, M. Hodson and B. Brohmann. 2008. The Contribution of Local Experiments and Negotiation Processes to Field-Level Learning in 
Emerging (Niche) Technologies: Meta-Analysis of 27 New Energy Projects in Europe. Bulletin of Science Technology Society 28(6): 464-477.

Rip, A., T. J. Misa, et al. 1995. Managing technology in society. London; New York, Pinter Publishers: Distributed in the United States and Canada by St. Martin's Press.

Rip, A. and J. Schot. 2002. Identifying Loci for Influencing the Dynamics of Technological Development. Shaping Technology, Guiding Policy: Concepts, Spaces \& Tools. K. H. Sørensen and R. Williams. Cheltenham/Northampton, Edward Elgar.

Schot, J. 2001. Towards new forms of participatory technology development. Technology Analysis \& Strategic Management 13 No. 1: 39-52.

Schot, J. and A. Rip. 1997. The past and future of Constructive Technology Assessment. Technological Forecasting and Social Change 54: 251-268.

Smith, A. 2007. Translating Sustainabilities between Green Niches and Socio-Technical Regimes. Technology Analysis \& Strategic Management 19(4): 427-450.

Späth, P. and H. Rohracher. 2009. Visions of urban energy system transitions: The eco-cities of Freiburg and Graz in retrospect. Paper presented at the 1. European Conference on Sustainability Transition, Amsterdam, 4./5. June 2009.

Szejnwald Brown, H., P. Vergragt, K. Green and L. Berchicci. 2003. Learning for sustainability transition through bounded socio-technical experiments in personal mobility. Technology Analysis \& Strategic Management 15(3): 291-315.

Szejnwald Brown, H. and P.J. Vergragt. 2008. Bounded socio-technical experiments as agents of systemic change: The case of a zero-energy residential building. Technological Forecasting \& Social Change 75: 107-130.

Van den Bosch, S.J.M., J.C. Brezet and Ph.J. Vergragt. 2005. How to kick off system innovation: a Rotterdam case study of the transition to a fuel cell transport system. Journal of Cleaner Production 13: 1027-1035.

Van Merkerk, R.O. and R.E.H.M. Smits. 2008. Tailoring Constructive Technology Assessment for Emerging Technologies. Technological Forecasting and Social Change 75(3): 312-333.

Vergragt, Ph.J. and H. Szejnwald Brown. 2007. Sustainable mobility: from technological innovation to societal learning. Journal of Cleaner Production 15: 1104-1115.

Weber, K. M., K. Kubeczko, K.H. Leitner, I. Oehme, H. Rohracher, P. Späth and K. Whitelegg. 2005. Transition zu nachhaltigen Produktionssystemen, Vienna: BMVIT. 


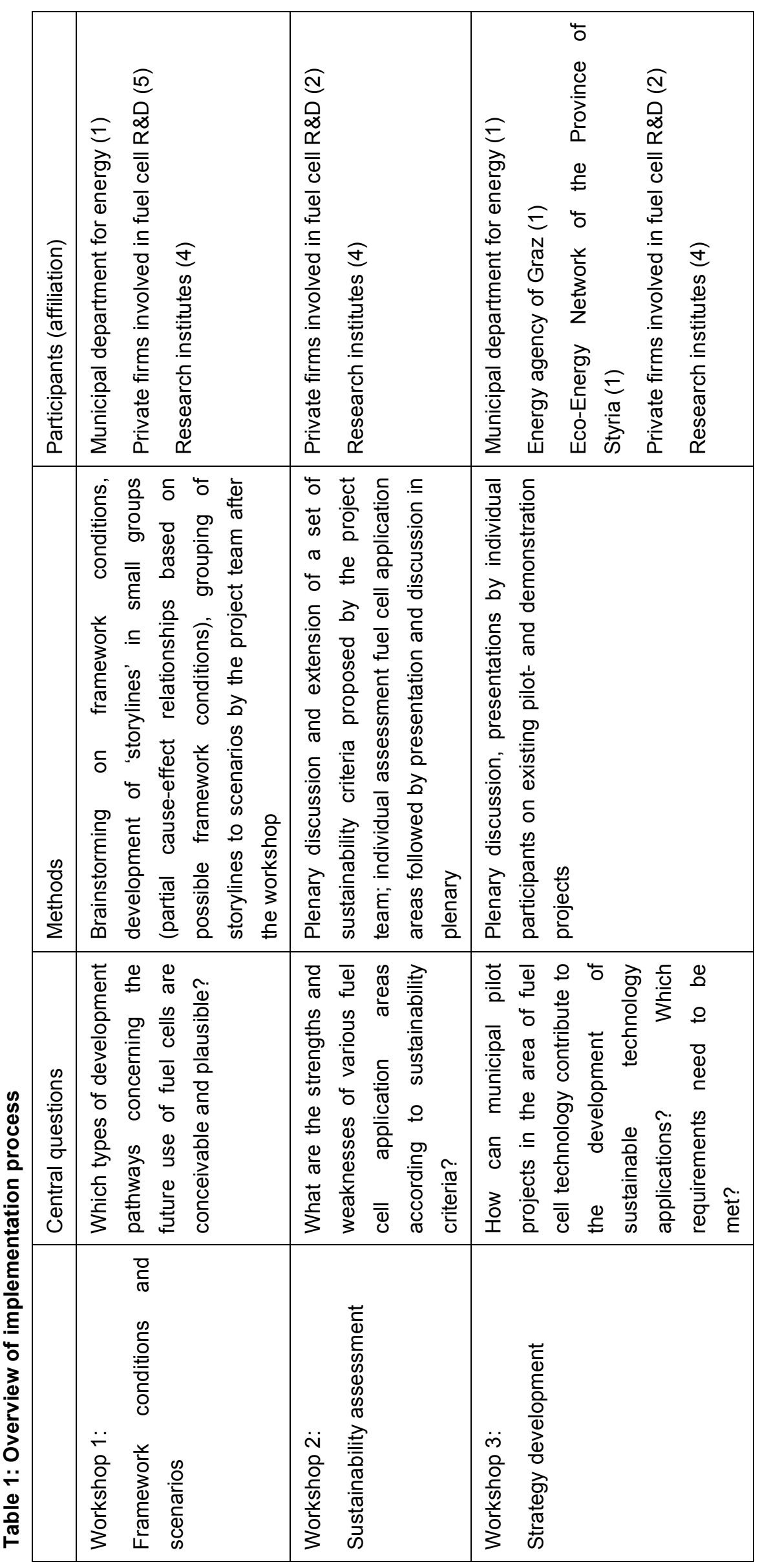


Box 1: Summary of central results of workshop series

Basic ranking of fuel cell applications for deployment in municipal context:

1. Applications in transport, such as fuel cell vehicles in public transport, municipal utility vehicles, vehicles used for logistics system for transporting goods to the inner city, on the longer term also private cars

2. Backup systems as a load balance to renewable energy sources or as emergency power supply for hospitals or computer servers

3. Fuel cell use for stationary energy supply

Requirements for the local embedding of pilot projects:

- In each individual case, comparing the possible benefit of fuel cell technology to technological alternatives

- Development of integrated concepts with regional and renewable fuel production

- Involvement of regional firms

- Orientation towards the needs of the municipality

- Taking account of political timeliness / awareness for potentially controversial issues

- Limiting organisational complexity

- Defining appropriate role for the municipality based on its interests and potentials. (Possibly making use of extraneous funding sources, e. g. national funding programmes) 


\section{Authors' biographies and contact details:}

Anna Schreuer, MSc

Inter-University Research Centre for Technology, Work and Culture (IFZ), Graz, Austria

Schlögelgasse 2, A-8010 Graz, Austria

Tel.: +43-316-813909-16

e-mail: schreuer@ifz.tugraz.at

Anna Schreuer studied mathematics at the University of Vienna and 'Science and Technology Studies' at the University of Edinburgh. After completing her studies she worked for the Sustainable Europe Research Institute (SERI), FAS.research and the University of Applied Sciences Technikum Wien. Since 2006 she is a researcher at the IFZ in Graz.

\section{Dr. Michael Ornetzeder (corresponding author)}

Institute of Technology Assessment, Austrian Academy of Sciences, Vienna, Austria

Strogasse 45/5, A-1030 Vienna, Austria

Tel.: +43-1-51581-6598

e-mail: ornetz@oeaw.ac.at

Michael Ornetzeder studied sociology and geography at the University of Vienna. He has worked as a researcher for the 'Gruppe Angepasste Technologie (GrAT)' at the Vienna University of Technology as department manager at the Centre for Social Innovation (ZSI) and as a senior researcher at the International Institute for Applied Systems Analysis (IIASA), Laxenburg. Since 2007 he is employed at the Institute of Technology Assessment at the Austrian Academy of Sciences in the field of Environmental Technology.

\section{Dr. Harald Rohracher}

Inter-University Research Centre for Technology, Work and Culture (IFZ), Graz, Austria Schlögelgasse 2, A-8010 Graz, Austria

Tel.: +43-316-813909-24

e-mail: rohracher@ifz.tugraz.at

Harald Rohracher studied technical physics at Graz University of Technology, Sociology at the University Graz and 'Science and Technology Policy' at SPRU, University of Sussex, UK. $\mathrm{He}$ is a founding member of the IFZ where he works since 1988. From 1999-2007 he was director of the IFZ. Currently he is a fellow at Harvard University at the Weatherhead Center for International Affairs (Josef A. Schumpeter fellowship). 